\title{
PIOTR KRAJEWSKI
}

\section{Oddziaływanie polityki fiskalnej na wahania koniunktury w Polsce}

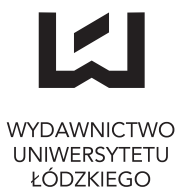

ŁÓDŹ 2013 
Piotr Krajewski - Katedra Funkcjonowania Gospodarki, Instytut Ekonomii

Wydział Ekonomiczno-Socjologiczny, Uniwersytet Łódzki, 90-214 Łódź, ul. Rewolucji 41/43

RECENZENT

Witold M. Orlowski

REDAKTOR WYDAWNICTWA UŁ

Elżbieta Marciszewska-Kowalczyk

SKŁAD I ŁAMANIE

ESUS - Agnieszka Buszewska

PROJEKT OKŁADKI

Barbara Grzejszczak

(C) Copyright by Uniwersytet Łódzki, Łódź 2013

Wydane przez Wydawnictwo Uniwersytetu Łódzkiego

Wydanie I. 6036/2013

ISBN (wersja drukowana) 978-83-7525-778-6

ISBN (ebook) 978-83-7969-237-8

Wydawnictwo Uniwersytetu Łódzkiego

90-131 Łódź, ul. Lindleya 8

www.wydawnictwo.uni.lodz.pl

e-mail: ksiegarnia@uni.lodz.pl

tel. (42) 66558 63, faks (42) 6655862 


\section{Spis treści}

Wstęp.

1. Mechanizmy podażowego oddziaływania polityki fiskalnej na gospodarkę w modelach realnego cyklu koniunkturalnego.

Wprowadzenie

1.1. Ogólna charakterystyka modeli realnego cyklu koniunkturalnego

1.2. Teoretyczne implikacje wprowadzenia polityki fiskalnej do modelu realnego cyklu koniunkturalnego

1.3. Wpływ stochastycznych zmian wydatków rządowych.

1.4. Oddziaływanie deterministycznych zmian w polityce fiskalnej.....

1.5. Analiza niezryczałtowanych podatków nakładanych na czynniki produkcji ............... 44

Podsumowanie.

2. Popytowe efekty polityki fiskalnej na gruncie nowej ekonomii keynesistowskiej ........ 53

Wprowadzenie

2.1. Ogólna charakterystyka modeli nowej ekonomii keynesistowskiej ............................ 55

2.2. Polityka fiskalna przy występowaniu sztywności nominalnych cen ............................ $\quad 60$

2.3. Oddziaływanie wydatków rządowych $w$ warunkach sztywności nominalnych płac ... $\quad 65$

2.4. Polityka fiskalna przy występowaniu przyzwyczajeń konsumpcyjnych ...................... 69

2.5. Implikacje występowania gospodarstw niericardiańskich.......................................... 73

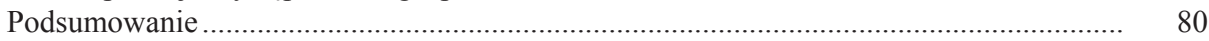

3. Ocena podażowych skutków szoków fiskalnych na podstawie modelu realnego cyklu koniunkturalnego dla gospodarki polskiej .

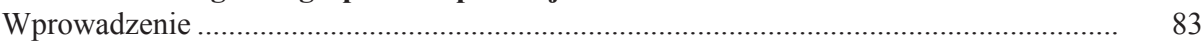

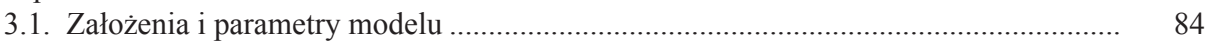

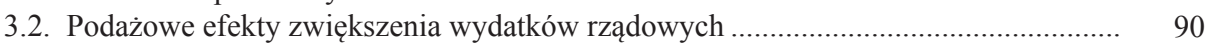

3.3. Skutki zmian stóp podatkowych ........................................................................... 98

3.4. Oddziaływanie wydatków rządowych finansowanych podatkami zależnymi od

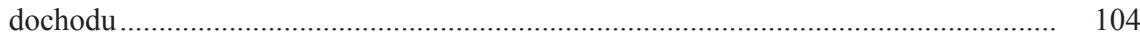

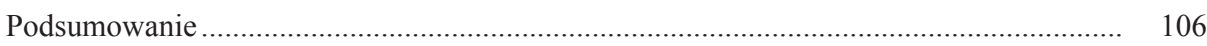

4. Oddziaływanie wydatków rządowych i podatków na wahania koniunktury w Polsce w świetle modelu nowokeynesistowskiego ….............................................................. 109

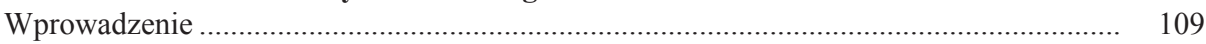

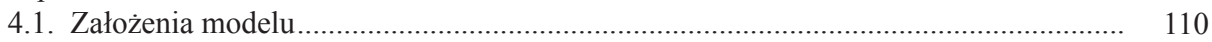

4.2. Metoda i wyniki estymacji parametrów.................................................................. 125

4.3. Skutki zwiększenia wydatków rządowych w sytuacji występowania sztywności nomi-

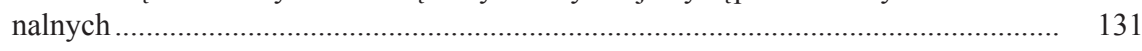

4.4. Oddziaływanie szoków dotyczących podatków niezryczałtowanych ......................... 138 
4.5. Wpływ wydatków rządowych finansowanych podatkami zależnymi od dochodu ....

5. Wpływ aktywnej i pasywnej polityki fiskalnej na przebieg cyklu koniunkturalnego w gospodarce polskiej

Wprowadzenie

5.1. Ogólna charakterystyka aktywnej i pasywnej polityki fiskalnej............................... 148

5.2. Metody wyodrębniania deficytu strukturalnego i cyklicznego ..................................... 152

5.3. Komponenty cykliczne dochodów oraz wydatków publicznych................................ 156

5.4. Wpływ aktywnej polityki fiskalnej na przebieg fluktuacji gospodarczych w Polsce .... $\quad 170$

5.5. Skuteczność automatycznych stabilizatorów i metody jej zwiększenia ...................... 177

Podsumowanie

Zakończenie

Literatura

Spis symboli 


\section{Wstęp}

Polityka fiskalna stanowi, obok monetarnej, jedno z dwóch podstawowych narzędzi makroekonomicznego oddziaływania państwa na gospodarkę. W okresie kryzysu finansowego, który rozpoczął się w 2007 roku, zwiększanie wydatków rządowych stało się $\mathrm{w}$ wielu krajach jednym z głównych instrumentów pobudzania gospodarki. Ekspansywna polityka fiskalna ma na celu przede wszystkim stymulowanie agregatowego popytu. Jednocześnie jednak zwiększanie wydatków rządowych lub obniżanie podatków, nawet w krótkim okresie, wywiera także skutki podażowe. Implikacje dotyczące wpływu polityki fiskalnej na fluktuacje gospodarcze są przy tym w obydwu przypadkach odmienne.

Opierając się na tradycyjnym podejściu keynesowskim, czyli przyjmując, że wzrost agregatowego popytu umożliwia napotykającym na barierę popytu firmom zwiększyć produkcję, otrzymuje się, że spowodowany ekspansywną polityką fiskalną wyższy poziom agregatowego popytu przekłada się na wzrost Produktu Krajowego Brutto. W efekcie następuje zwiększenie zatrudnienia, dochodów do dyspozycji i konsumpcji, a poprzez efekt mnożnikowy również dalszy wzrost konsumpcji. Natomiast zgodnie z podejściem podażowym, stosowanym m.in. w modelach realnego cyklu koniunkturalnego, wydatki rządowe wpływają na zachowanie gospodarstw domowych głównie poprzez efekt majątkowy, powodując wzrost zatrudnienia i produkcji, a jednocześnie spadek konsumpcji. Kierunek oddziaływania wzrostu wydatków rządowych na konsumpcję jest więc w modelach podażowych odmienny niż w tradycyjnym podejściu keynesowskim.

Od czasów Wielkiego Kryzysu do obecnego kryzysu finansowego nacisk kładziony na popytowe i podażowe efekty polityki fiskalnej ulegał znacznym zmianom. Doświadczenia wyniesione z Wielkiego Kryzysu z lat 30. ubiegłego wieku przyczyniły się do tego, że ekonomiści zaczęli postrzegać politykę fiskalną jako narzędzie stymulowania agregatowego popytu. Po zapoczątkowanym przez Keynesa długotrwałym okresie koncentracji na popytowych skutkach polityki fiskalnej, od lat 70. i 80. ubiegłego wieku, zaczęto podkreślać podażowe mechanizmy oddziaływania wydatków rządowych i podatków na gospodarkę. Pod koniec XX w., wraz z dynamicznym rozwojem nowej ekonomii keynesistowskiej ${ }^{1}$, nastąpił renesans

${ }^{1}$ W pracy za Wojtyną (2010) stosowane jest thumaczenie „nowa ekonomia keynesistowska”. Warto jednocześnie zaznaczyć, że w literaturze krajowej używane jest również określenie „nowa ekonomia keynesowska". 
badań nad popytowymi efektami polityki fiskalnej. W ostatnich latach, ze względu na istotne znaczenie polityki fiskalnej jako narzędzia walki z kryzysem, nasiliło się zainteresowanie oceną efektywności oddziaływania wydatków rządowych i podatków na agregatowy popyt i przebieg fluktuacji gospodarczych.

Mechanizm popytowego oddziaływania polityki fiskalnej jest zupełnie odmienny niż w przypadku oddziaływania podażowego. Każdy z nich wywiera również inne skutki makroekonomiczne. A zatem oszacowanie popytowego i podażowego oddziaływania wydatków rządowych oraz podatków na wahania koniunktury stanowi istotny warunek określenia optymalnej w danych warunkach polityki fiskalnej.

Zbadanie, w jaki sposób polityka fiskalna oddziałuje na fluktuacje gospodarcze w Polsce jest przy tym w obecnych czasach szczególnie uzasadnione. Od siły wpływu wydatków rządowych i podatków na wahania koniunktury uzależniona jest efektywność polityki fiskalnej jako narzędzia stymulowania gospodarki w okresie kryzysu gospodarczego na świecie. Również w dłuższej perspektywie, w kontekście planowanego pełnego uczestnictwa Polski w Unii Gospodarczej i Walutowej, oszacowanie siły oddziaływania polityki fiskalnej na wahania gospodarcze nabiera rosnącego znaczenia. W strefie euro polityka pieniężna Europejskiego Banku Centralnego odpowiada bowiem jedynie na szoki występujące w skali całej Unii, natomiast na poziomie poszczególnych krajów prowadzenie antycyklicznej polityki makroekonomicznej spoczywa na instrumentach fiskalnych.

Z powyższych względów główny cel pracy stanowi oszacowanie siły podażowego oraz popytowego oddziaływania polityki fiskalnej na wahania koniunktury w Polsce. Podjęta w pracy analiza dotyczy skutków polityki fiskalnej w ramach cyklu koniunkturalnego ${ }^{2}$. Nie uwzględnia jej efektów długookresowych, w tym możliwego wpływu polityki fiskalnej na kształtowanie się postępu technicznego.

W pracy poddano weryfikacji następujące hipotezy główne, dotyczące oddziaływania polityki fiskalnej w polskiej gospodarce:

1) wydatki rządowe silniej wpływają na wahania PKB niż zmiany stóp podatkowych;

2) popytowe oddziaływanie wydatków rządowych na fluktuacje PKB jest silniejsze niż ich oddziaływanie podażowe;

3) zmiany stóp podatkowych wpływają na kształtowanie się fluktuacji produkcji w większym stopniu poprzez efekty podażowe niż popytowe;

4) prowadzona w Polsce polityka fiskalna ma charakter antycykliczny.

${ }^{2}$ Choć istnieje wiele rożnych sposobów definiowania, pomiaru i modelowania cykli koniunkturalnych (por. np. Goodwin, 1967; Milo, 2000, 2005), to obecnie zazwyczaj analizuje się makroekonomiczne cykle koniunkturalne rozumiane jako trwające od około sześciu do trzydziestu dwóch kwartałów wahania aktywności gospodarczej, w której wyróżnia się występowanie dwóch faz: ożywienia gospodarczego oraz recesji (por. np. Baxter, King, 1995; Christiano, Fitzgerald, 1999; Harding, Pagan, 1999; Skrzypczyński, 2006, 2010). W analogiczny sposób definiowany jest cyk1 koniunkturalny w niniejszej pracy. 
Poniżej przedstawiono przesłanki, którymi kierowano się przy przyjmowaniu hipotez badawczych.

Z szeroko rozpowszechnionego podejścia popytowego nie uwzględniającego mechanizmów mikroekonomicznych wynika, że wydatki rządowe oddziałują na gospodarkę mocniej niż zmiany opodatkowania, które wpływają na agregatowy popyt jedynie pośrednio, poprzez dochód do dyspozycji. Z tego względu przyjęto hipotezę o relatywnie silniejszym wpływie wydatków rządowych na fluktuacje gospodarcze. Jednocześnie zbadano w ten sposób, czy uwzględnienie również podażowych mechanizmów oddziaływania polityki fiskalnej na wahania koniunktury zmienia wnioski wynikające $\mathrm{z}$ podejścia popytowego.

W przypadku stóp podatkowych, odmiennie niż dla wydatków rządowych, przyjęto hipotezę, że ich oddziaływanie podażowe jest silniejsze niż popytowe. Wynika to z następujących przesłanek. Po pierwsze, jak wskazano powyżej, podatki oddziałują na agregatowy popyt jedynie pośrednio, podczas gdy wydatki rządowe stanowią składnik agregatowego popytu, bezpośrednio wpływając na jego wysokość. Po drugie, stopy podatkowe oddziałują na wielkości krańcowe, takie jak krańcowy produkt pracy i kapitału, które, jak wskazują modele teoretyczne, wywierają istotny podażowy wpływ na decyzje gospodarstw domowych i przedsiębiorstw.

Zgodnie z funkcją stabilizacyjną polityka fiskalna powinna ograniczać wahania koniunktury. Weryfikując hipotezę dotyczącą antycykliczności zbadano, czy prowadzona w Polsce polityka fiskalna przyczyniła się do zmniejszenia fluktuacji gospodarczych.

W pracy, oprócz hipotez głównych, postawione zostały następujące hipotezy pomocnicze, dotyczące oddziaływania polityki fiskalnej na polską gospodarkę:

1) zwiększenie opodatkowania kapitału wywiera większy podażowy wpływ na PKB niż wzrost podatków nakładanych na dochody z pracy;

2) wydatki rządowe substytucyjne względem konsumpcji prywatnej w mniejszym stopniu przyczyniają się do stymulowania aktywności gospodarczej niż wydatki rządowe niebędące substytutami konsumpcji prywatnej;

3) aktywna polityka fiskalna przyczyniła się do relatywnie dobrej sytuacji gospodarczej w Polsce w okresie kryzysu gospodarczego na świecie;

4) automatyczne stabilizatory koniunktury w większym stopniu wpływają na wygładzenie wahań koniunktury w gospodarce polskiej niż aktywna polityka fiskalna.

Hipotezy poddano weryfikacji, wykorzystując analizy teoretyczne oraz empiryczne oparte na danych dotyczących gospodarki polskiej z lat 1995-2010. Badania przeprowadzono na gruncie modelu realnego cyklu koniunkturalnego oraz modelu nowokeynesistowskiego, stanowiących rozwinięcia modeli Hansena (1985) oraz Smetsa i Woutersa (2003). Modele te zaliczane są do grupy dynamicznych, stochastycznych modeli równowagi ogólnej (Dynamic Stochastic General Equilibrium, DSGE), które, jak wskazują m.in. Canova i Paustian (2010), 
są obecnie główną metodą prowadzenia analiz dotyczących wahań koniunktury. Zaletą modelowania gospodarki przy wykorzystaniu tego typu modeli jest ich oparcie na podstawach mikroekonomicznych, czyli na decyzjach optymalizacyjnych poszczególnych gospodarstw domowych i przedsiębiorstw ${ }^{3}$. W Polsce badania wykorzystujące metodologię dynamicznych, stochastycznych modeli równowagi ogólnej skoncentrowane są głównie na polityce pieniężnej, zaliczyć do nich można m.in. opracowania Kolasy (2008), Kolocha (2008), Gradzewicza i Makarskiego (2009), Baranowskiego (2011) czy Kuchty (2012). W pracach tych analizy dotyczące polityki fiskalnej nie są prowadzone, bądź też stanowią jedynie niewielki dodatek do analiz poświęconych polityce pieniężnej. Spośród polskich badań, opartych na metodologii modeli DSGE, jedynie praca Bukowskiego i in. (2005) jest poświęcona głównie polityce fiskalnej. Polityka fiskalna jest tam jednak analizowana, odmiennie niż w niniejszej pracy, nie na podstawie danych dla gospodarki polskiej, lecz w oparciu o parametry charakterystyczne dla gospodarki amerykańskiej oraz strefy euro.

Podłoże teoretyczne prowadzonych w pracy analiz dotyczących podażowych mechanizmów oddziaływania polityki fiskalnej na wahania koniunktury stanowi teoria realnego cyklu koniunkturalnego. Teoria ta, podobnie jak monetaryzm oraz nowa ekonomia klasyczna, podkreśla znaczenie czynników podażowych, a jednocześnie ma spośród nich najsilniejsze fundamenty mikroekonomiczne. Natomiast efekty popytowe polityki fiskalnej zbadano na gruncie nowej ekonomii keynesistowskiej, kierując się analogicznymi przesłankami, jak w przypadku analizy efektów podażowych. Nowa ekonomia keynesistowska w większym bowiem stopniu niż ortodoksyjny keynesizm opiera się na podstawach mikroekonomicznych ${ }^{4}$.

Praca składa się z pięciu rozdziałów. W pierwszym rozdziale, na podstawie modeli realnego cyklu koniunkturalnego, teoretycznej analizie poddany został podażowy wpływ polityki fiskalnej na gospodarkę. Rozdział rozpoczyna się od przedstawienia ogólnej charakterystyki modeli realnego cyklu koniunkturalnego,

${ }^{3}$ Zastosowane w pracy modele cechują się wysokim stopniem sformalizowania, typowym dla dynamicznych, stochastycznych modeli równowagi ogólnej. Zasadność zmatematyzowania tzw. „ekonomii głównego nurtu” jest obecnie przedmiotem burzliwej dyskusji w Polsce i na świecie (por. np. Wojtyna, 2008; Krugman, 2009; Kwaśnicki, 2012; Małecki-Tepicht, 2012; Wilkin, 2012). Jak stwierdza Krugman (2009) „ekonomia zeszła na manowce, ponieważ ekonomiści wybrali źle rozumiane piękno formalnych modeli, zamiast oddać się poszukiwaniu prawdy" (tłumaczenie za: Hardt, 2012, s. 35). Aby nie popełnić tego błędu, w pracy modele zastosowano jedynie jako niezbędne narzędzie, a nie są one celem samym w sobie. Mają za zadanie uporządkować i ułatwić analizę oraz w tym stopniu, w jakim to możliwe, pamiętając o ich ograniczeniach, umożliwić wyciągnięcie wniosków odnoszących się do realnej gospodarki.

${ }^{4}$ Jak wskazuje Wojtyna (2000) istnieje wiele kryteriów wyodrębniania szkół makroekonomicznych. Przedstawiony podział opiera się na klasyfikacji Snowdona, Vane'a i Wynarczyka (1998). Warto zaznaczyć, że wyodrębniają oni jeszcze dwa, alternatywne w stosunku do „ekonomii głównego nurtu”, podejścia - szkołę postkeynesowską oraz austriacką. 
w których przyjmuje się, że kształtowanie się agregatowego popytu nie wpływa na sferę realną, co umożliwia wyodrębnienie podażowego wpływu wydatków rządowych i podatków na gospodarkę. W ramach analizy podażowych efektów polityki fiskalnej w pierwszej kolejności przedstawiono teoretyczne implikacje wprowadzenia polityki fiskalnej do modeli realnego cyklu koniunkturalnego. Następnie zaprezentowany został wpływ stochastycznych zmian w wydatkach rządowych na odwzorowanie przez model zależności makroekonomicznych. W dalszych częściach rozdziału zbadano skutki przejściowego oraz trwałego zwiększenia wydatków rządowych i podatków, a także bardziej szczegółowo przedstawiono podażowe oddziaływanie na gospodarkę podatków nakładanych na poszczególne czynniki produkcji.

Zgodnie z podejściem keynesistowskim polityka fiskalna oddziałuje na gospodarkę przede wszystkim poprzez kształtowanie agregatowego popytu. $Z$ tego względu drugi rozdział pracy poświęcony jest analizie efektów polityki fiskalnej w warunkach występowania sztywności nominalnych cen oraz płac. Rozdział rozpoczyna się przedstawieniem ogólnej charakterystyki opartych na postawach mikroekonomicznych modeli uwzględniających popytowe efekty polityki fiskalnej, tj. modeli nowej ekonomii keynesistowskiej, określanych również jako modele nowej syntezy neoklasycznej. Stanowią one syntezę neoklasycznej metodologii dynamicznych, stochastycznych modeli równowagi ogólnej z keynesistowskim założeniem, dotyczącym krótkookresowych sztywności nominalnych w gospodarce. W rozdziale ukazane zostało oddziaływanie wydatków rządowych i podatków w warunkach sztywności nominalnych cen i płac, a także w sytuacji występowania przyzwyczajeń konsumpcyjnych oraz gospodarstw niericardiańskich.

$\mathrm{W}$ rozdziale trzecim, na podstawie analizy teoretycznej zawartej w pierwszym rozdziale, zbadane zostało podażowe oddziaływanie polityki fiskalnej w Polsce na kształtowanie się produkcji i pozostałych podstawowych zmiennych makroekonomicznych. Podażowe efekty polityki fiskalnej oszacowano w oparciu o model realnego cyklu koniunkturalnego z niepodzielną pracą, który rozszerzono o założenia dotyczące polityki fiskalnej5. Rozdział rozpoczyna się przedstawieniem założeń oraz parametrów modelu, oszacowanych na podstawie danych dla gospodarki polskiej. Następnie zaprezentowano dynamikę modelu oraz omówiono makroekonomiczne skutki zwiększenia wydatków rządowych finansowanych

\footnotetext{
${ }^{5}$ Wyodrębnienie efektów podażowych jest również możliwe na gruncie modeli nowej ekonomii keynesistowskiej, poprzez założenie zerowych wartości parametrów określających występowanie sztywności nominalnych. Zastosowanie modelu realnego cyklu koniunkturalnego ma jednak następujące zalety z punktu widzenia analizy skutków podażowych. Po pierwsze, założenia dotyczące strony podażowej są w nich bardziej rozbudowane niż w modelach nowej ekonomii keynesistowskiej. Po drugie, w modelach nowej ekonomii keynesistowskiej, ze względu na ich bardziej skomplikowaną strukturę, dostosowaną do analizy popytowej, interpretacja uzyskanych wyników dotyczących efektów podażowych jest mniej czytelna niż w przypadku wyników otrzymanych na podstawie modelu realnego cyklu koniunkturalnego.
} 
deficytem budżetowym lub zryczałtowanymi podatkami, tj. podatkami nieuzależnionymi od dochodu. W dalszej kolejności poddano analizie wpływ zmian stóp podatkowych. W końcowej części rozdziału zamieszczono wyniki symulacji dotyczących podażowych skutków zwiększenia wydatków rządowych finansowanych wyższymi podatkami dochodowymi.

Rozdział czwarty zawiera analizę empiryczną dotyczącą wpływu polityki fiskalnej na wahania koniunktury w warunkach występowania sztywności nominalnych, a więc przy uwzględnieniu efektów popytowych. Podstawę teoretyczną przeprowadzonej analizy stanowią modele nowej ekonomii keynesistowskiej, omówione w rozdziale drugim. W pierwszej kolejności przedstawiono założenia modelu oraz zaprezentowano wyniki estymacji parametrów. Parametry modelu wyznaczono na podstawie danych kwartalnych dla gospodarki polskiej, przy wykorzystaniu estymacji bayesowskiej. Następnie pokazano wynikające z analizowanego modelu skutki zmian wydatków rządowych oraz stóp podatkowych.

Politykę fiskalną podzielić można na polityką aktywną oraz pasywną, tj. wynikającą z występowania automatycznych stabilizatorów koniunktury. Każda $\mathrm{z}$ nich ma odmienny charakter oraz przyczyny występowania. $\mathrm{Z}$ tego względu $\mathrm{w}$ ostatnim, piątym rozdziale pracy, zbadano oddziaływanie polityki fiskalnej na przebieg fluktuacji gospodarczych w Polsce w rozbiciu na aktywną politykę fiskalną oraz automatyczne stabilizatory koniunktury. W ramach dekompozycji deficytu sektora finansów publicznych na komponent strukturalny oraz komponent cykliczny, związany z występowaniem automatycznych stabilizatorów, oszacowano lukę produktową oraz elastyczności poszczególnych kategorii budżetowych względem PKB. Następnie, opierając się na przeprowadzonych szacunkach dotyczących oddziaływania wydatków rządowych i podatków na PKB ukazano, w jaki sposób aktywna oraz pasywna polityka fiskalna przyczyniła się do niwelowania wahań koniunktury w gospodarce polskiej. Końcowa część pracy zawiera podsumowanie oraz wnioski z przeprowadzonych analiz. 


\section{Mechanizmy podażowego oddziaływania polityki fiskalnej na gospodarkę w modelach realnego cyklu koniunkturalnego}

\section{Wprowadzenie}

Niniejszy rozdział zawiera teoretyczną analizę efektów podażowych polityki fiskalnej. Podłoże teoretyczne do analizy podażowego oddziaływania polityki fiskalnej na fluktuacje gospodarcze stanowią modele realnego cyklu koniunkturalnego (Real Business Cycle, RBC).

W zapoczątkowanych przez Kydlanda i Prescotta (1982) modelach realnego cyklu koniunkturalnego zakłada się, że wahania gospodarcze nie wynikają z odchyleń produkcji od poziomu potencjalnego, lecz z decyzji optymalizacyjnych gospodarstw domowych (por. Plosser, 1989; McCandless, 2008). Szoki technologiczne, lub inne źródła zaburzeń, nie powodują więc powstawania bezrobocia, mimo że poprzez międzyokresową substytucję czasu wolnego generują wahania poziomu zatrudnienia (por. np. Hansen, Wright, 1992; Snowdon, Vane, Wynarczyk, 1998). Płace i ceny są doskonale elastyczne i natychmiast dostosowują się do poziomu równoważącego rynek (por. Stadler, 1994; Jarociński, 1997; Ljungqvist, Sargent, 2004). W rezultacie na sferę realną oddziałuje jedynie podażowa strona gospodarki, co umożliwia wyodrębnienie podażowych efektów zmian polityki fiskalnej. W pierwszych modelach RBC (modele Kydlanda i Prescotta, 1982; Hansena, 1985) zakładano, że jedyne źródło szoków stanowią zmiany technologiczne. Modele RBC zostały rozszerzone o politykę fiskalną na przełomie lat 80. i 90. XX w. (m.in. modele Aschauera 1988; Christiano i Eichenbauma 1992; Baxter i Kinga, 1993; McGrattan, 1994). W ramach analizy wpływu polityki fiskalnej na gospodarkę w modelach RBC bada się przede wszystkim oddziaływanie przejściowej i trwałej zmiany wydatków rządowych oraz niezryczałtowanych podatków ${ }^{1}$.

W modelach RBC wpływ wydatków rządowych na zachowanie gospodarstw domowych dokonuje się głównie poprzez efekt majątkowy. Wzrost wydatków rządowych powoduje negatywny efekt majątkowy, który przekłada się na wzrost podaży pracy i produkcji, a ograniczenie konsumpcji i stawki płac (por. np. Baxter i King, 1993; Ljungqvist, Sargent, 2004). Z kolei niezryczałtowane podatki na gruncie modeli RBC oddziałują na gospodarkę poprzez wpływ na wielkości

${ }^{1} \mathrm{Tj}$. podatków oddziałujących na decyzje gospodarstw domowych, uzależnionych np. od poziomu dochodu. 
krańcowe - poziom krańcowego produktu kapitału po opodatkowaniu oraz krańcowego produktu pracy po opodatkowaniu.

Układ rozdziału pierwszego jest następujący: rozpoczyna się od przedstawienia ogólnej charakterystyki standardowego modelu RBC, tj. modelu uwzględniającego występowanie jedynie szoków technologicznych. Stanowi on punkt odniesienia w stosunku do analiz wpływu polityki fiskalnej na gospodarkę w bardziej rozbudowanych modelach, uwzględniających wpływ wydatków rządowych oraz podatków. Następnie zaprezentowane zostały teoretyczne implikacje wprowadzenia polityki fiskalnej do modeli realnego cyklu koniunkturalnego. W dalszej kolejności analizie zostały poddane podażowe efekty stochastycznych i deterministycznych zmian w polityce fiskalnej. W końcowej części rozdziału przedstawiono oddziaływanie na gospodarkę podatków nakładanych na poszczególne czynniki produkcji.

\subsection{Ogólna charakterystyka modeli realnego cyklu koniunkturalnego}

Modele realnego cyklu koniunkturalnego zapoczątkował pionierski artykuł Kydlanda i Prescotta (1982). Kydland i Prescott oparli analizę wahań koniunktury na badaniu oddziaływania na gospodarkę szoków technologicznych przyjmując, że zmiany technologiczne wpływają nie tylko na długookresową ścieżkę PKB, ale również na wahania cykliczne ${ }^{2}$. Podażowe szoki technologiczne mające charakter stochastycznych impulsów, poprzez mechanizmy wzmacniające powodują długotrwałe odchylenia produkcji oraz pozostałych zmiennych makroekonomicznych od poziomu ustalonego (steady-state) (por. McCandless, 2008). Jednocześnie w modelu Kydlanda i Prescotta, a także późniejszych modelach RBC, zakłada się doskonale elastyczne ceny i płace, co powoduje, że agregatowy popyt nie oddziałuje na fluktuacje produkcji i umożliwia wyodrębnienie wpływu czynników podażowych. W modelach RBC przyjmuje się ponadto, że podmioty gospodarcze posiadają pełną informację i działają racjonalnie, a PKB równa się produkcji potencjalnej. Fluktuacje aktywności gospodarczej wynikają z reakcji maksymalizujących użyteczność gospodarstw domowych na zmieniające się warunki gospodarcze (por. Plosser 1989; Ljungqvist, Sargent, 2004). Wynika stąd, że nawet $\mathrm{w}$ doskonale efektywnej gospodarce jest miejsce na wahania koniunkturalne (por. Grabek, Kłos, Koloch, 2010).

Modele RBC stanowily diametralną zmianę w podejściu do makroekonomii, wskazując na (por. Gali, 2008):

- efektywność wykorzystania zasobów w warunkach występowania fluktuacji gospodarczych,

${ }^{2}$ Szerzej na temat znaczenia pracy Kydlanda i Prescotta (1982) por. The Royal Swedish Academy of Sciences (2004). 
- kluczowe znaczenie szoków technologicznych w generowaniu wahań koniunktury,

- brak wpływu czynników monetarnych na przebieg fluktuacji gospodarczych ${ }^{3}$.

Do podstawowych zalet modelu RBC zalicza się ich oparcie na mikropodstawach. W rezultacie są one odporne na krytykę Lucasa (1976) i nie opierają się na licznych arbitralnych restrykcjach, które wpływają na wyniki otrzymywane na podstawie modeli makroekonometrycznych dużej skali (por. Sims, 1980). Z drugiej jednak strony kwestionowane jest zakładane w modelach RBC znaczenie szoków technologicznych oraz brak wpływu polityki monetarnej (por. np. Snowdon, Vane, Wynarczyk, 1998; Fischer, 2006). Badania empiryczne z reguły wskazują bowiem, że szoki technologiczne nie stanowią kluczowego czynnika generującego fluktuacje gospodarcze (por. Christiano, Eichenbaum, Vigfusson, 2003; Gali, Rabanal, 2004; Fischer, 2006), a polityka monetarna oddziałuje na przebieg wahań koniunktury (por np. Friedman, Schwartz, 1963; Christiano, Eichenbaum, Evans, 1998).

Jedno z pierwszych rozwinięć modelu Kydlanda i Prescotta stanowił model Hansena (1985). Hansen wprowadził do modeli RBC założenie o niepodzielnej pracy, czyli założenie, że poszczególne osoby mogą albo pracować określoną ilość czasu, albo nie pracować w ogóle (por. Kuchta, Piłat, 2010). Model Hansena stanowi obok modelu Kydlanda i Prescotta jeden z dwóch podstawowych modeli realnego cyklu koniunkturalnego, zarazem zapis modelu przedstawiony przez Hansena jest bardziej „współczesny” i częściej wykorzystywany w późniejszych modelach RBC. Jednocześnie model Hansena w większym stopniu niż model Kydlanda i Prescotta umożliwia identyfikację przyczyn występowania fluktuacji (por. McCandless, 2008). Z tego względu przedstawiona poniżej charakterystyka standardowego modelu RBC opiera się na modelu Hansena (1985).

W standardowym modelu RBC zakłada się, że gospodarstwa domowe są homogeniczne i podejmują takie decyzje dotyczące poziomu konsumpcji i czasu wolnego, aby maksymalizować wartość oczekiwaną sumy zdyskontowanych użyteczności konsumpcji i czasu wolnego, tj. funkcję postaci:

$U=E\left(\sum_{t=0}^{\infty} \beta^{t} u\left(c_{t}, h_{t}\right)\right)$,

gdzie:

$E$ - operator wartości oczekiwanej,

$\beta$ - subiektywny czynnik dyskontowy,

$u\left(c_{t}, h_{t}\right)$ - funkcja użyteczności chwilowej gospodarstwa domowego w okresie $t\left(u_{t}\right)^{4}$,

${ }^{3}$ Warto przy tym zaznaczyć, że modele RBC posiadają wiele wariantów (por. np. Hansen, Wright, 1992), które ze względu na odmienność założeń cechują się innymi własnościami ekonomicznymi. W szczególności, w niektórych modelach RBC wskazywano na występowanie wpływu czynników monetarnych na sferę realną nawet w warunkach doskonale elastycznych cen i płac (por. Cooley, Hansen, 1989).

${ }^{4} \mathrm{~W}$ dalszej części pracy symbole z subskryptem $t$ oznaczają wartość danej zmiennej w okresie $t$. 
$c_{t}-$ konsumpcja,

$h_{t}-$ czas wolny.

Przyszła użyteczność jest ceniona w mniejszym stopniu niż obecna, a więc $\beta \in(0,1)$. Funkcja użyteczności $u$ jest niezmienna w czasie, ma dodatnie pierwsze pochodne cząstkowe względem konsumpcji i czasu wolnego, a zarazem ujemną drugą pochodną cząstkową względem konsumpcji: $\frac{\partial u_{t}}{\partial c_{t}}>0, \frac{\partial^{2} u_{t}}{\partial c_{t}{ }^{2}}<0, \frac{\partial u_{t}}{\partial h_{t}}>0$. Spełniającą ww. warunki funkcją użyteczności jest funkcja postaci:

$u\left(c_{t}, h_{t}\right)=\ln \left(c_{t}\right)+A V\left(h_{t}\right)$,

gdzie $A$ oznacza miarę wagi przypisywanej czasowi wolnemu, $A>0, V^{\prime}\left(h_{t}\right)>0{ }^{5}$. W modelu z niepodzielną pracą funkcja $V$, określająca wpływ czasu wolnego na użyteczność, przyjmuje postać (por. Hansen, 1985; Kuchta, Piłat, 2010) ${ }^{6}$ :

$V\left(l_{t}\right)=H-l_{t}$,

gdzie:

$H$ - dostępny zasób czasu ogółem,

$l_{t}$ - podaż pracy $^{7}$.

Firmy są homogeniczne, działają w warunkach konkurencji doskonałej i maksymalizują zyski. W standardowym modelu RBC przyjmuje się funkcję produkcji Cobba-Douglasa o stałych efektach skali:

$y_{t}\left(z_{t}, k_{t}, l_{t}\right)=e^{z_{t}} k_{t}^{\theta} l_{t}^{1-\theta}$,

gdzie:

$y_{t}$ - produkcja,

$k_{t}-$ kapitał $^{8}$

${ }^{5}$ Inny przykład często stosowanej w modelach RBC funkcji użyteczności stanowi funkcja określająca gospodarstwo domowe cechujące się stałą względną awersją do ryzyka, czyli funkcja postaci: $u\left(c_{t}, h_{t}\right)=\left(\frac{c_{t} h_{t}^{A}}{1-\sigma_{c}}\right)^{1-\sigma_{c}}, \sigma_{c}>0$, (por. np. Dejong, Dave, 2007).

${ }^{6} \mathrm{~W}$ przypadku niepodzielnej pracy gospodarstwa domowe wybierają prawdopodobieństwo podjęcia pracy, a następnie losowo jest określane czy dane gospodarstwo pracuje, czy pozostaje bez pracy. Ponieważ wszystkie gospodarstwa są identyczne, wybierają takie same prawdopodobieństwo podjęcia pracy, jednak wynik losowania będzie odmienny dla poszczególnych gospodarstw.

${ }^{7} \mathrm{~W}$ modelu z podzielną pracą zakłada się natomiast: $V\left(l_{t}\right)=\ln \left(H-l_{t}\right)$.

${ }^{8} \mathrm{~W}$ modelu analizowany jest kapitał rzeczowy. W modelach RBC inne rodzaje kapitału, takie jak kapitał ludzki, społeczny i finansowy (por. np. Milo, Szafrański, 2005; Sztaudynger, 2005; Milo $i$ in., 2006) nie są z reguły uwzględniane. 
$z_{t}-$ szoki technologiczne,

$\theta$ - elastyczność produkcji względem kapitału,

$\theta \in(0,1)$.

Ważnym elementem charakteryzującym funkcję produkcji jest występowanie $\mathrm{w}$ niej zmiennej w czasie łącznej produktywności czynników produkcji (total factor productivity, TFP). Łączna produktywność czynników produkcji $\left(e^{z_{t}}\right)$ w modelu RBC jest wielkością stochastyczną, uzależnioną od podażowych szoków technologicznych. Wpływ impulsu polegającego na zmianie poziomu TFP rozciąga się na wiele okresów. Zarazem jednak, mimo iż często przyjmuje się, że zmiany podażowe mają charakter trwały, nadając szeregom czasowym charakter błądzenia przypadkowego (por. Nelson, Plosser, 1982), to w modelach RBC rezygnuje się z tego założenia, utrzymując, że wpływ poszczególnych impulsów słabnie z okresu na okres.

W standardowym modelu RBC szoki technologiczne określone są poprzez proces autoregresyjny (por. np. Dejong, Dave, 2007):

$z_{t}=\left(1-\rho_{z}\right) \bar{z}+\rho_{z} z_{t-1}+\varepsilon_{z, t}, \varepsilon_{z, t} \sim N\left(0, \sigma_{\varepsilon, z}{ }^{2}\right)$,

w którym współczynnik autoregresji $\left(\rho_{z}\right)$ jest nieznacznie niższy od jedności, gwarantując stacjonarność zmiennej, a zarazem zapewniając utrzymywanie się przez wiele okresów wpływu szoku technologicznego na funkcję produkcji.

W pierwszych modelach RBC, w których m.in. nie uwzględniano polityki fiskalnej, zakładano, że wytworzona produkcja może być przeznaczona jedynie na konsumpcję lub inwestycje:

$c_{t}+i_{t}=y_{t}$,

gdzie:

$i_{t}$ - inwestycje.

Gospodarstwa rezygnują z części konsumpcji, ponieważ poziom inwestycji dodatnio wpływa na zasób kapitału w przyszłości:

$k_{t+1}=i_{t}+(1-\delta) k_{t}$,

gdzie $\delta$ oznacza stopę deprecjacji, $\delta \in(0,1)$.

W gospodarce określonej poprzez powyższe równania gospodarstwa domowe zastają pewien zasób kapitału oraz pewien poziom TFP (zmienne stanu) i dokonują takich wyborów, które maksymalizują ich wartość oczekiwaną sumy zdyskontowanych użyteczności (por. np. Ljungqvist, Sargent, 2004; McCandless, 2008). Gospodarstwa domowe ustalając czas pracy jednocześnie podejmują decyzje dotyczące ilości czasu wolnego. Zarazem wybór poziomu konsumpcji określa, jaka ilość dochodu może być przeznaczona na inwestycje, a to z kolei determinuje 
przyszły zasób kapitału. Alternatywnie, wybór gospodarstw domowych dotyczyć może przyszłego poziomu kapitału, który determinuje wysokość konsumpcji i inwestycji ${ }^{9}$. W takim przypadku otrzymuje się, że w standardowym modelu RBC $\mathrm{z}$ niepodzielną pracą gospodarstwa domowe maksymalizują oczekiwaną sumę zdyskontowanych użyteczności postaci ${ }^{10}$ :

$U=E \sum_{t=0}^{\infty} \beta^{t}\left\{\ln \left[e^{z_{t}} k_{t}^{\theta} l_{t}^{1-\theta}+(1-\delta) k_{t}-k_{t+1}\right]+A\left(1-l_{t}\right)\right\}$.

Wartości zmiennych decyzyjnych są wynikiem optymalnych decyzji gospodarstw domowych. Aby określić wartości wszystkich zmiennych modelu potrzebna jest jedynie znajomość parametrów, zasobu kapitału w okresie początkowym i wpływu poszczególnych szoków technologicznych (reprezentowanych przez składnik losowy).

$\mathrm{W}$ wielu przypadkach, po konstrukcji modelu teoretycznego w oparciu o dane statystyczne następuje jego weryfikacja ekonometryczna. W modelach realnego cyklu koniunkturalnego często rezygnuje się z estymacji parametrów metodami ekonometrycznymi oraz z badania zgodności dopasowania danych wynikających z modelu z danymi empirycznymi (por. Dejong, Dave, 2007). Wynika to po części z faktu, że modele RBC są bardzo ogólne i nie uwzględniają wielu zakłóceń występujących w realnej gospodarce i mających znaczący wpływ na wartości zmiennych. Zarazem ścieżki realizacji zmiennych w modelach RBC są bardzo wrażliwe na niewielkie zmiany założeń lub wartości zmiennych. W rezultacie, uznanie dopasowania modelu do danych rzeczywistych za najważniejsze kryterium umożliwia wyestymowanie równań, co prawda dobrze dopasowanych w obrębie próby, ale nieoddających zależności ekonomicznych i nienadających się do prognozowania poza próbą. $\mathrm{Z}$ tego też względu w modelach $\mathrm{RBC}$ zamiast estymacji na podstawie rzeczywistych danych często stosuje się symulacje oparte na sztucznych danych, wygenerowanych na podstawie równań modelu (por. np. Snowdon, Vane, Wynarczyk, 1998; Barillas i in., 2007; Griffoli, 2007). Wnioski dotyczące zachowania się gospodarki modelowej przeprowadza się po wykonaniu odpowiednio dużej, określonej przez badacza, liczby symulacji i obliczeniu charakterystyk szeregów czasowych wygenerowanych przez model. Następnie porównuje się odchylenia standardowe i współczynniki korelacji występujące w gospodarce modelowej z odpowiednimi charakterystykami rzeczywistej gospodarki. Model oceniany jest na podstawie podobieństwa modelowych i rzeczywistych dynamicznych charakterystyk zmiennych ekonomicznych (por. Kuchta, Piłat, 2010).

Badanie zgodności statystycznych właściwości zmiennych wygenerowanych oraz rzeczywistych wymaga wyodrębnienia z szeregów czasowych elementu

\footnotetext{
${ }^{9}$ Przyjęcie za zmienną decyzyjną przyszłej ilości kapitału zamiast konsumpcji jest wygodniejsze ze względów obliczeniowych (McCandless, 2008).

${ }^{10}$ Przy znormalizowaniu całkowitego zasobu czasu wolnego do jedności.
} 
cyklicznego. Wysokość komponentów cyklicznych uzależniona jest przy tym od metody szacowania produkcji potencjalnej, którą wyznaczyć można m.in. na podstawie filtrów statystycznych, takich jak filtr Hodricka i Prescotta (1980), Baxter i Kinga (1995), Christiano i Fitzgeralda (1999), lub w oparciu o funkcję produkcji. Na kształtowanie się charakterystyk zmiennych modelu duży wpływ mają również wartości parametrów. Wartości te uzyskać można w wyniku kalibracji (por. np. Kydland i Prescott, 1982 i 1996; Hansen 1985; Summers, 1986). Kalibracja polega na wyborze takich wartości parametrów, które mają ekonomiczne uzasadnienie i powodują, że model generuje dane o regularnościach przypominających fluktuacje W rzeczywistej gospodarce (por. Canova, 2007) ${ }^{11}$. W standardowym modelu RBC występuje siedem parametrów: $\beta, A, \delta, \rho_{z}, \bar{z}, \theta, \sigma_{\varepsilon, z}{ }^{2}$. Wartości tych parametrów zależą od tego, jaka jest częstotliwość danych ${ }^{12}$. Poniżej przedstawiono typowo przyjmowane wartości parametrów (por. np. Hansen, Wright, 1992; Jarociński, 1997). Stopę deprecjacji kapitału $\delta$ zazwyczaj kalibruje się na poziomie wynoszącym 2,5\% kwartalnie, czyli około $10 \%$ rocznie. Charakteryzujący funkcję produkcji parametr $\theta$ wyznaczyć można jako średni udział dochodu z kapitału w dochodzie całkowitym. Autoregresję łącznej produktywności czynników produkcji, umożliwiającą transmisję szoków podażowych na inne okresy, określa współczynnik $\rho_{z}$, który najczęściej przyjmuje się na poziomie 0,95 . Oznacza to bardzo silną autoregresję przy jednoczesnym zachowaniu stacjonarności TFP. Wariancja składnika losowego $\sigma_{\varepsilon, z}{ }^{2}$, przy danym współczynniku autoregresji $\rho_{z}$, określa zmienność TFP. Wariancję $\sigma_{\varepsilon, z}{ }^{2}$ wyznaczyć można oparciu o dane dotyczące wariancji produkcji, tj. na takim poziomie, aby odchylenie standardowe produkcji w modelu zrównać z rzeczywistą zmiennością produkcji. Średnia wartość łącznej produktywności czynników produkcji jest zazwyczaj normalizowana do jedności. Parametr $A$ uzyskuje się w wyniku przekształceń funkcji opisanej równaniem (8) na podstawie wzoru ${ }^{13}$ :

$$
A=\frac{\left(\frac{1}{l}-1\right)(1-\theta)}{1-\delta \frac{k}{y}} \text {. }
$$

${ }^{11}$ Wśród innych metod wyznaczania parametrów modelu DSGE wymienić można m.in. estymację w oparciu o funkcję wiarygodności (por. np. Altug, 1989; Canova, 2007; Dejong, Dave, 2007), estymację przy wykorzystaniu uogólnionej metody momentów (por. np. Christiano i Eichenbaum, 1992; Canova 2007), minimalizację dystansu pomiędzy funkcjami reakcji na impuls uzyskanymi na podstawie modelu i na podstawie wektorowej autoregresji (por. Christiano, Eichenbaum i Evans 2005; Rotemberg i Woodford 1997) oraz podejście bayesowskie (por. Schorfheide, 2000; Smets, Wouters, 2003; Rabanal, Rubio-Ramirez, 2005; Gradzewicz, Makarski, 2009).

${ }^{12} \mathrm{~W}$ zależności od częstotliwości danych przede wszystkim zmienia się stosunek zasobów do strumieni.

${ }^{13}$ Najpierw oblicza się pochodną względem ilości pracy i przyrównuje ją do zera (co jest jednym z warunków koniecznych maksymalizacji funkcji opisanej równaniem (8)). Następnie zakłada się równowagę długookresową, co umożliwia pominięcie indeksów oznaczających czas 
Związany z użytecznością subiektywny czynnik dyskontujący $\beta$ w krajach rozwiniętych przyjmuje się na poziomie $0,99 \mathrm{w}$ ujęciu kwartalnym, czyli ok. 0,96 w skali roku.

Na podstawie standardowego modelu RBC otrzymuje się, że zwiększenie się łącznej produktywności czynników produkcji prowadzi do wzrostu zatrudnienia (por. np. Hansen, Wright, 1992; Kuchta, Piłat, 2010). Wpływ szoków technologicznych na poziom zatrudnienia w modelu RBC wynika z międzyokresowej substytucji czasu wolnego. Gospodarstwa domowe, maksymalizując użyteczność, podejmują decyzje dotyczące czasu wolnego i czasu pracy. W okresach wysokiej łącznej produktywności czynników produkcji dodatkowa godzina pracy zapewnia wyższą konsumpcję, co powoduje przejściowe zmniejszenie czasu wolnego i zwiększenie podaży pracy. Zarazem jednak w modelach realnego cyklu koniunkturalnego szoki technologiczne nie prowadzą do występowania przymusowego bezrobocia, ponieważ zmiany zatrudnienia wynikają z dobrowolnych wyborów gospodarstw domowych dotyczących pracy i czasu wolnego (por. Snowdon, Vane, Wynarczyk, 1998). Wyniki standardowego modelu RBC wskazują również, że pozytywny szok technologiczny prowadzi do wyższych inwestycji i podniesienia się ilości kapitału. W wyniku pozytywnego szoku technologicznego zwiększeniu ulegają więc obydwa czynniki produkcji, co w połączeniu z wyższą łączną produktywnością czynników produkcji przekłada się na znaczy przejściowy wzrost produkcji. Jednocześnie zwiększeniu ulega konsumpcja. Wzrost konsumpcji jest jednak relatywnie niewielki, ze względu na skłonność gospodarstw domowych do wygładzania wahań konsumpcji w czasie (por. np. McCandless, 2008).

\subsection{Teoretyczne implikacje wprowadzenia polityki fiskalnej do modelu realnego cyklu koniunkturalnego}

Jak wskazano we wcześniejszej części rozdziału, pierwsze modele RBC (modele Kydlanda i Prescotta, 1982 oraz Hansena, 1985) nie uwzględniały występowania polityki fiskalnej. Jednocześnie wprowadzenie do modelu wydatków rządowych wpływa w istotny sposób na decyzje gospodarstw domowych, przede wszystkim poprzez efekt majątkowy. Występowanie podażowych efektów polityki fiskalnej w modelach RBC jest również następstwem:

- oddziaływania wydatków rządowych na poziom użyteczności gospodarstw domowych,

- wpływu wydatków rządowych na kształtowanie się możliwości produkcyjnych,

- oddziaływania podatków na krańcowe produkty kapitału i pracy.

i wykorzystanie zależności: $i-\delta k=0$, czyli: $y=c-\delta k$. W rezultacie, wykorzystując wcześniej wyznaczone parametry oraz dane dotyczące średniej ilości czasu pracy $(l)$ i średniego stosunku kapitału do produktu $(k / y)$, otrzymuje się wzór na parametr $A$ określony równaniem (9). 
Główne teoretyczne implikacje wynikające z prowadzenia wydatków rządowych i podatków do modeli realnego cyklu koniunkturalnego przedstawione zostały w modelu Aschauera (1988).

W modelu zakłada się, że poziom wydatków rządowych oddziałuje na produktywność czynników produkcji (por. Barro, 1990; Turnovsky, 2000; Linnemann i Schabert, 2005) ${ }^{14}$. Funkcja produkcji jest funkcją potęgową postaci ${ }^{15}$ :

$$
y_{t}=f\left(k_{t}, l_{t}, g_{t}\right)=k_{t}^{\theta_{k}} l_{t}^{\theta_{l}} g_{t}^{\theta_{g}} \text {, }
$$

gdzie:

$$
\begin{aligned}
& g_{t}-\text { wydatki rządowe, } \\
& \theta_{k}+\theta_{l}+\theta_{g}=1, \theta_{k}, \theta \in(0,1) .
\end{aligned}
$$

Korzystając $\mathrm{z}$ własności funkcji potęgowej o stałych efektach skali powyższą funkcję produkcji można zapisać następująco:

$$
y_{t}=\rho_{t} k_{t}+w_{t} l_{t}+\mu_{t} g_{t}
$$

gdzie:

$w_{t}$ - realna stawka płac (krańcowy produkt pracy),

$\rho_{t}-$ krańcowy produkt kapitału,

$\mu_{t}$ - krańcowy produkt dóbr i usług dostarczanych przez państwo ${ }^{16}$, $w_{t}, \rho_{t}>0$.

Badania empiryczne wskazują, że wydatki rządowe stanowią z reguły czynnik zwiększający produktywność (por. Gramlich, 1994; Linnemann i Schabert, 2005), czyli zachodzi: $\mu_{t}>0$. Wydatki rządowe wpływają nie tylko na produktywność, ale także na poziom zadowolenia gospodarstw domowych ${ }^{17}$, które maksymalizują następującą wartość oczekiwaną sumy zdyskontowanych użyteczności:

$$
U=E\left(\sum_{t=0}^{\infty} \beta^{t} u\left(c_{t}, l_{t}, g_{t}\right)\right)
$$

${ }^{14} \mathrm{~W}$ części modeli RBC przyjmuje się także, że na kształtowanie się możliwości produkcyjnych ma również wpływ poziom kapitału publicznego (por. np. Baxter i King, 1993; Bukowski i in., 2005) oraz zatrudnienie w sektorze publicznym (por. Ardagna, 2006).

${ }^{15}$ Aschauer (1988) przyjmuje w funkcji produkcji (a także w ograniczeniu budżetowym) poziom kapitału z okresu poprzedniego $k_{t}-1$, jednak w celu zachowania spójności oznaczeń z innymi modelami przedstawionymi w pracy, w opisie modelu przyjęto $\mathrm{w}$ funkcji produkcji (oraz w ograniczeniu budżetowym) bieżący poziom kapitału, co nie wpływa na wnioski wynikające z modelu.

${ }^{16}$ Czyli: $\rho_{t}=\frac{\partial f\left(k_{t}, l_{t}, g_{t}\right)}{\partial k_{t}}, w_{t}=\frac{\partial f\left(k_{t}, l_{t}, g_{t}\right)}{\partial l_{t}}, \mu_{t}=\frac{\partial f\left(k_{t}, l_{t}, g_{t}\right)}{\partial g_{t}}$.

${ }^{17}$ Do typowych wydatków rządowych wpływających na poziom użyteczności gospodarstw domowych zaliczyć można m.in. wydatki rządowe związane ze służbą zdrowia, kulturą, rekreacją itp. 
gdzie:

$$
\frac{\partial u_{t}}{\partial c_{t}}>0, \frac{\partial u_{t}}{\partial l_{t}}<0, \frac{\partial u_{t}}{\partial g_{t}}>0
$$

Na użyteczność gospodarstwa domowego wpływ ma zatem zarówno poziom konsumpcji prywatnej, jak i konsumpcji publicznej ${ }^{18}$. Definiując „efektywną konsumpcję" jako konsumpcję gospodarstw domowych wynikającą z konsumpcji prywatnej oraz z konsumpcji przez gospodarstwo domowe dóbr i usług dostarczanych przez państwo otrzymuje się (por. Bailey, 1971):

$$
c_{t}^{e}=c_{t}+\gamma g_{t},
$$

gdzie:

$$
\begin{aligned}
& c_{t}^{e} \text { - efektywna konsumpcja, } \\
& \gamma \in<0,1>\text {. }
\end{aligned}
$$

Parametr $\gamma^{19}$ określa siłę wpływu wydatków rządowych na efektywną konsumpcję. Oznacza on jednocześnie krańcową stopę substytucji pomiędzy konsumpcją prywatną a konsumpcją dóbr publicznych. Szacunki krańcowej stopy substytucji pomiędzy konsumpcją prywatną a konsumpcją dóbr publicznych znacznie się od siebie różnią. Przykładowo Aschauer (1985) dla gospodarki amerykańskiej uzyskał oszacowanie krańcowej stopy substytucji pomiędzy konsumpcją prywatną a publiczną w granicach 0,2-0,4, podczas gdy według Amano i Wirjanto (1997) wynosi 0,9 . Wyniki niektórych badań wskazują nawet, że konsumpcja publiczna stanowi dobro komplementarne względem konsumpcji prywatnej (por. Ismail, 2010) ${ }^{20}$.

W ramach analizy wpływu krańcowej stopy substytucji pomiędzy konsumpcją prywatną a konsumpcją dóbr publicznych na zachowanie gospodarstw domowych warto rozważyć dwa skrajne przypadki, tj. gdy $\gamma=0$ oraz $\gamma=1$.

Dla $\gamma=0$ wydatki rządowe nie powiększają użyteczności gospodarstw domowych z konsumpcji prywatnej (por. np. Cooper, 1997). Należy przy tym zaznaczyć, że przyjęcie, iż wydatki rządowe nie powiększają użyteczności gospodarstw domowych z konsumpcji prywatnej, nie jest jednoznaczne z założeniem, że wydatki rządowe nie wpływają na poziom użyteczności gospodarstw domowych (por. Christiano, Eichenbaum, 1992). Wydatki rządowe mogą bowiem oddziaływać

${ }^{18}$ Przykładowo, poziom zadowolenia gospodarstw domowych uzależniony jest zarówno od wysokości wydatków prywatnych na zakup książek, jak i wydatków publicznych związanych $\mathrm{z}$ utrzymaniem bibliotek.

${ }^{19}$ Ambler, Bouakez, Cardia (2010) analizują również implikacje teoretyczne występowania sytuacji, w której wydatki rządowe stanowią dobro komplementarne względem konsumpcji prywatnej, czyli taki, dla którego zachodzi $\gamma<0$.

${ }^{20}$ Szerzej na temat badań dotyczących substytucyjności pomiędzy konsumpcją publiczną a prywatną por. Karras (1994), Ho (2001), Okubo (2003), Bouakez, Rebei (2007), Ambler, Bouakez, Cardia (2010). 
osobnym, niepowiązanym z konsumpcją prywatną, kanałem na poziom użyteczności gospodarstwa domowego. Funkcja użyteczności przyjmuje wówczas postać:

$U=E\left(\sum_{t=0}^{\infty} \beta^{t} u\left(c_{t}, l_{t}\right)+\Gamma\left(g_{t}\right)\right)$,

gdzie:

$\Gamma^{\prime}\left(g_{t}\right)>0$.

Addytywne dodanie członu $\Gamma\left(g_{t}\right)$ nie wpływa na decyzje gospodarstw domowych, ponieważ wydatki rządowe są egzogenicznym, niezależnym od decyzji gospodarstw domowych, procesem stochastycznym.

$Z$ kolei gdy $\gamma=1$, wówczas na poziom użyteczności gospodarstw domowych z konsumpcji wpływa suma konsumpcji prywatnej i konsumpcji publicznej $\left(c_{t}+g_{t}\right)$. W takim przypadku, przy założeniu, że wydatki rządowe nie wpływają na produktywność, egzogeniczny szok dotyczący wydatków rządowych powoduje analogiczne wyparcie konsumpcji prywatnej, sprawiając, że pozostałe zmienne (np. produkcja, ilość kapitału i nakład pracy) pozostają niezmienione ${ }^{21}$.

W modelu występują dwa rodzaje podatków: niezryczałtowane (zależne od dochodu) oraz zryczałtowane (niezależne od dochodu). W przypadku podatków niezryczałtowanych, stopa opodatkowania jest jednakowa dla dochodów z kapitału, dochodów z pracy oraz dochodów z papierów wartościowych i nie występuje progresja podatkowa. Dzięki występowaniu jednakowej stopy podatkowej dla różnych rodzajów dochodów możliwe jest łączne rozpatrywanie decyzji gospodarstw domowych i przedsiębiorstw ${ }^{22}$.

Uwzględniając występowanie opodatkowania otrzymuje się ograniczenie budżetowe gospodarstwa domowego postaci:

$\left(b_{t+1}-b_{t}\right)+i_{t}+c_{t}=w_{t} l_{t}+\rho_{t} k_{t}+r_{t} b_{t}+\mu_{t} g_{t}-\tau_{t} w_{t} l_{t}-\tau_{t}\left(\rho_{t}-\delta\right) k_{t}-\tau_{t} r_{t} b_{t}-T_{t}$

gdzie:

$\tau_{t}$ - stopa opodatkowania dochodów,

$T_{t}^{t}$ - podatki zryczałtowane (ang. lump sum taxes),

$b_{t}-$ obligacje posiadane przez gospodarstwo domowe ${ }^{23}$,

$r_{t}-$ stopa procentowa.

${ }^{21} \mathrm{~W}$ rezultacie niewystępowanie w modelach RBC wydatków rządowych interpretować można jako przyjęcie założenia, że polityka fiskalna nie oddziałuje na funkcję produkcji, a na użyteczność gospodarstw domowych z konsumpcji wpływa suma konsumpcji prywatnej i konsumpcji publicznej.

${ }^{22}$ Zachowanie się gospodarstw domowych i przedsiębiorstw w przypadku bardziej skomplikowanego systemu podatkowego przedstawione zostało m.in. przez Brocka i Turnovsky'ego (1981), McGrattan (1994), Ljungqvista i Sargenta (2004), Bukowskiego i in. (2005) oraz Ferroniego (2010).

${ }^{23}$ Zarówno publiczne, jak i prywatne. W modelu obligacje emitowane przez podmioty prywatne i przez państwo są dla gospodarstw domowych doskonałymi substytutami. 
Jak wynika z równania (15), w modelu zakłada się, że produkcja wytwarzana przez państwo nie jest opodatkowana.

Równanie (15) można zapisać w postaci:

$$
\begin{aligned}
& \left(b_{t+1}-b_{t}\right)+\left(k_{t+1}-k_{t}+\delta k_{t}\right)+c_{t}= \\
& =w_{t} l_{t}+\rho_{t} k_{t}+r_{t} b_{t}-\tau_{t}\left(w_{t} l_{t}+\rho_{t} k_{t}+r_{t} b_{t}\right)+\tau_{t} \delta k_{t}-T_{t}+\mu_{t} g_{t},
\end{aligned}
$$

po przekształceniach otrzymując:

$\left(b_{t+1}-b_{t}\right)+\left(k_{t+1}-k_{t}\right)+c_{t}+T_{t}=\left(1-\tau_{t}\right)\left[w_{t} l_{t}+\left(\rho_{t}-\delta\right) k_{t}+r_{t} b_{t}\right]+\mu_{t} g_{t}$.

Ograniczenie budżetowe państwa określa następujące równanie:

$$
\left(b_{t+1}^{g}-b_{t}^{g}\right)+g_{t}=T_{t}+\tau_{t}\left[w_{t} l_{t}+\left(\rho_{t}-\delta\right) k_{t}+r_{t} b_{t}\right]+r_{t} b_{t}^{g},
$$

gdzie:

$b_{t}^{g}$ - obligacje posiadane przez państwo.

Ograniczenie budżetowe gospodarstw domowych można zapisać w postaci:

$$
\sum_{t=1}^{\infty} \hat{R}_{t}\left[c_{t}+\left(1-\tau_{t}\right) w_{t}\left(1-l_{t}\right)\right]=k_{0}+b_{0}+\sum_{t=1}^{\infty} \hat{R}_{t}\left[\left(1-\tau_{t}\right) w_{t}+\mu_{t} g_{t}-T_{t}\right] \text {, }
$$

gdzie $k_{0}$ oraz $b_{0}$ oznacza odpowiednio początkowy zasób kapitału i obligacji, natomiast czynnik dyskontowy $\hat{R}_{t}$ określony jest wzorem:

$$
\hat{R}_{t}=\frac{1}{\left[1+\left(1-\tau_{1}\right) r_{1}\right]\left[1+\left(1-\tau_{2}\right) r_{2}\right] \ldots\left[1+\left(1-\tau_{t}\right) r_{t}\right]} \text {. }
$$

Równanie (19) pokazuje, że wartość obecna wydatków na konsumpcję i czas wolny musi się równać początkowej wartości majątku powiększonej o wartość obecną (po opodatkowaniu) zasobu czasu wolnego i produkcji dostarczanej przez państwo, pomniejszonego o podatki zryczałtowane.

Analogiczny zapis można zastosować w przypadku ograniczenia budżetowego państwa, otrzymując:

$$
\sum_{t=1}^{\infty} \hat{R}_{t} g_{t}=b_{0}^{g}+\sum_{t=1}^{\infty} \hat{R}_{t}\left\{T_{t}+\tau_{t}\left[w_{t} l_{t}+\left(\rho_{t}-\delta\right) k_{t}+r_{t} b_{t}\right]\right\} \text {. }
$$

Powyższe równanie oznacza, że obecna wartość wydatków rządowych musi równać się początkowej wartości obligacji posiadanych przez państwo powiększonych o wartość obecną podatków zryczałtowanych i dochodowych.

Przyjmując, że jedyną formę opodatkowania stanowią podatki zryczałtowane, równanie (19), określające ograniczenie budżetowe gospodarstw domowych przyjmuje postać: 


$$
\sum_{t=1}^{\infty} \hat{R}_{t}\left[c_{t}+w_{t}\left(1-l_{t}\right)\right]=k_{0}+b_{0}+\sum_{t=1}^{\infty} \hat{R}_{t}\left[w_{t}+\mu_{t} g_{t}-T_{t}\right]
$$

natomiast ograniczenie budżetowe państwa upraszcza się do postaci:

$$
\sum_{t=1}^{\infty} \hat{R}_{t} g_{t}=b_{0}^{g}+\sum_{t=1}^{\infty} \hat{R}_{t} T_{t}
$$

gdzie:

$$
\hat{R}_{t}=\frac{1}{\left(1+r_{1}\right)\left(1+r_{2}\right) \ldots\left(1+r_{t}\right)},
$$

Podstawiając równanie (23) do równania (22) uzyskuje się, że w gospodarce, w której występują jedynie zryczałtowane podatki, ograniczenie budżetowe gospodarstw domowych przyjmuje postać:

$$
\sum_{t=1}^{\infty} \hat{R}_{t}\left[c_{t}+w_{t}\left(1-l_{t}\right)\right]=k_{0}+b_{0}+\sum_{t=1}^{\infty} \hat{R}_{t}\left(w_{t}+\mu_{t} g_{t}\right)-\left(\sum_{t=1}^{\infty} \hat{R}_{t} g_{t}-b_{0}^{g}\right)
$$

czyli:

$$
\sum_{t=1}^{\infty} \hat{R}_{t}\left[c_{t}+w_{t}\left(1-l_{t}\right)\right]=k_{0}+\left(b_{0}+b_{0}^{g}\right)+\sum_{t=1}^{\infty} \hat{R}_{t}\left[w_{t}-\left(1-\mu_{t}\right) g_{t}\right]
$$

W ograniczeniu budżetowym określonym równaniem (26) nie występują zryczałtowane podatki. Zatem zachowanie się gospodarstw domowych nie jest uzależnione od rozkładu podatków w czasie. Zachodzi wskazana przez Barro (1974) ekwiwalencja ricardiańska pomiędzy długiem publicznym a finansowaniem wydatków budżetowych ze zryczałtowanych podatków (por. też Krawczyk, 2007; Moździerz, 2009). Zatem w modelu obniżka podatków niezależnych od dochodu, której towarzyszy wzrost deficytu budżetowego, nie prowadzi do wzrostu konsumpcji. Gospodarstwa domowe, oczekując w przyszłości wyższych podatków koniecznych dla spłacenia zaciągniętego długu, zwiększają na ich poczet oszczędności. W takim przypadku pojawienie się deficytu budżetowego nie powoduje wzrostu stóp procentowych ${ }^{24}$.

Ekwiwalencja ricardiańska, choć wynika z założeń teoretycznych, jest często kwestionowana na gruncie praktycznym (por. np. Tobin, 1978; Moździerz, 2009). Jako potencjalne przyczyny nie występowania ekwiwalencji ricardiańskiej wskazać można m.in. skończony horyzont planowania, występowanie ograniczeń płynności na rynku kapitałowym, czy postępowanie gospodarstw domowych według „reguł praktycznych” (por. Romer, 2000).

${ }^{24}$ Dodatkowemu deficytowi towarzyszy taki bowiem sam co do wielkości wzrost oszczędności prywatnych. Jeżeli jednak ekwiwalencja ricardiańska nie występuje, wówczas w wyniku obniżki zryczałtowanych podatków, której towarzyszy wzrost deficytu budżetowego, z jednej strony rośnie konsumpcja, a z drugiej strony dochodzi do wypchania inwestycji. 
Skończony horyzont planowania wiąże się z faktem, że konsumenci nie żyją wiecznie, a więc zaciągnięcie długu w chwili obecnej jest dla nich okazją do zwiększenia konsumpcji kosztem przyszłych pokoleń, które będą musiały ten dług spłacić (por. Bernheim, 1987, 1991). Ponadto na rynku kapitałowym występować mogą różnice pomiędzy oprocentowaniem długu publicznego i oprocentowaniem kredytu gospodarstw domowych, a część gospodarstw może w ogóle nie mieć dostępu do rynku kredytowego. W takim przypadku zaciągnięcie zobowiązań przez państwo może stanowić okazję do zwiększenia chwilowej konsumpcji przez niektórych konsumentów, którzy nie mogli sobie na to pozwolić ze względu na istniejące ograniczenia płynności (por. Hubbard, Judd, 1986; Krawczyk, 2009). Kolejną przyczyną, dla której hipoteza ekwiwalencji ricardiańskiej może nie odpowiadać rzeczywistości, jest również nie w pełni racjonalne postępowanie konsumentów, którzy zamiast optymalizacji mogą kierować się uproszczonymi sposobami postępowania (por. Tversky, Kahneman, 1974; Campbell, Mankiw, 1989) ${ }^{25}$.

W celu wyodrębnienia wypływu wydatków rządowych Aschauer przyjmuje upraszczające założenie, że występują jedynie podatki zryczałtowane. Zakładając ponadto, że w początkowym okresie poziom kapitału oraz obligacji publicznych i prywatnych jest równy zero, a parametr $\mu_{t}$ określający krańcowy produkt wydatków rządowych jest stały, otrzymuje się następujące ograniczenie budżetowe gospodarstw domowych:

$$
\sum_{t=1}^{\infty} \hat{R}_{t}\left[c_{t}+w_{t}\left(1-l_{t}\right)\right]=\sum_{t=1}^{\infty} \hat{R}_{t}\left[w_{t}-(1-\mu) g_{t}\right]
$$

czyli:

$$
\sum_{t=1}^{\infty} \hat{R}_{t}\left[c_{t}^{e}+w_{t}\left(1-l_{t}\right)\right]=\sum_{t=1}^{\infty} \hat{R}_{t}\left[w_{t}-(1-\mu-\gamma) g_{t}\right]
$$

${ }^{25}$ Biorąc pod uwagę wymienione zastrzeżenia dotyczące ekwiwalencji ricardiańskiej, Romer (2000) konkluduje, że chociaż stanowi ona atrakcyjną propozycję teoretyczną, to jednak jej zastosowanie empirycznie jest ograniczone. Jednocześnie warto zaznaczyć, że finansowania dodatkowych wydatków rządowych deficytem budżetowym poprzez tzw. efekty niekeynesowskie, może pogorszyć oczekiwania dotyczące stabilności finansów publicznych, co przyczynić się może m.in. do zmniejszenia zainteresowania inwestorów daną gospodarką i prowadzić do wzrostu premii za ryzyko. Silne efekty niekeynesowskie polityki fiskalnej występują z reguły w krajach, w których poziom długu publicznego w relacji do PKB jest wysoki (por. Alesina i Perotti, 1996; Giavazzi i Pagano, 1998; Mitra, 2006; Afonso, Baxa i Slavík, 2011). Jak wskazuje Rzońca (2007), również niezależnie od początkowej sytuacji fiskalnej, zmniejszenie wydatków rządowych może poprzez efekty niekeynesowskie wpływać pozytywnie na gospodarkę - stymulując inwestycje i zmniejszając presję na wynagrodzenia (szerzej na temat efektów niekeynesowskich por. Rzońca, 2004, 2007; Rzońca i Ciżkowicz, 2005; Borys, Ciżkowicz i Rzońca, 2011). Na możliwość zwiększenia się PKB w wyniku efektów niekeynesowskich obniżenia wydatków publicznych wskazują analizy Hagemejera, Jędrzejowicza i Żółkiewskiego (2011). 
Wyrażenie $(1-\mu-\gamma)$ ukazuje $\mathrm{w}$ jakim stopniu wydatki rządowe oddziałują na poziom majątku gospodarstw domowych. Dla $\mu+\gamma=1$ zasoby gospodarcze zabrane przez państwo z sektora prywatnego dostarczają gospodarstwom domowym, poprzez zwiększone wydatki rządowe, ekwiwalentnych korzyści do tych, jakie przynosiłoby gospodarstwom domowym wykorzystanie zasobów. Na całkowitą korzyść gospodarstwa domowego ze zwiększonych wydatków rządowych składa się z jednej strony fakt, że wydatki rządowe przekładają się na wyższą produkcję (siłę tego wpływu ukazuje parametr $\mu$ ), a z drugiej strony to, że wydatki rządowe w pewnym stopniu zwiększają użyteczność gospodarstw domowych $\mathrm{z}$ konsumpcji (siłę tego wpływu ukazuje parametr $\gamma$ ). W rezultacie wydatki rządowe nie wpływają na poziom majątku i decyzje gospodarstw domowych.

Natomiast jeżeli $\mu+\gamma<1$, wówczas wzrost wydatków rządowych obniża poziom majątku gospodarstw domowych, czyli wywiera negatywny efekt majątkowy (por. Barro, 1981) ${ }^{26}$. Wynikający z przejściowego zwiększenia wydatków rządowych negatywny efekt majątkowy oddziałuje na zachowania gospodarstw domowych dwoma kanałami. Po pierwsze w okresie relatywnie gorszej sytuacji gospodarstw domowych pojawia się nadwyżkowy popyt. W okresie przejściowego wzrostu wydatków rządowych zmiana agregatowego popytu $\left(\Delta y_{t}^{d}\right)$ określona jest wzorem:

$\Delta y_{t}^{d}=\Delta c_{t}+\Delta g_{t}$,

czyli:

$\Delta y_{t}^{d}=\Delta c_{t}^{e}+(1-\gamma) \Delta g_{t}$.

Przy niezmienionej stopie procentowej gospodarstwo domowe nie zmienia decyzji dotyczących efektywnej konsumpcji i ilości pracy, a zatem:

$\Delta y_{t}^{d}=(1-\gamma) \Delta g_{t}$.

Wynikającą z wzrostu wydatków rządowych zmianę agregatowej podaży $\left(\Delta y_{t}^{s}\right)$ określa natomiast równanie:

$\Delta y_{t}^{s}=\mu \Delta g_{t}$.

Otrzymuje się więc:

$\Delta e_{t}=(1-\gamma) \Delta g_{t}-\mu \Delta g_{t}=(1-\gamma-\mu) \Delta g_{t}$.

gdzie: $\Delta e_{t}$ oznacza zmianę różnicy pomiędzy agregatowym popytem a podażą ${ }^{27}$. $\mathrm{Z}$ powyższego równania wynika, że dla $\mu+\gamma<1$ dochodzi do pojawienia się

\footnotetext{
${ }^{26}$ Jak wskazują szacunki Aschauera (1985) i Achmeda (1986) warunek ten jest zazwyczaj spełniony.

${ }^{27}$ Przy założeniu, że przed zmianą wydatków rządowych na rynku dóbr występowała równowaga, $\Delta e_{t}$ oznacza również nadwyżkowy popyt.
} 
nadwyżkowego popytu. W celu przywrócenia równowagi następuje wzrost stopy procentowej. Uwzględniając wpływ zwiększenia się stopy procentowej na rynek pracy otrzymuje się, że w efekcie ma miejsce wzrost produkcji dany wzorem:

$$
\Delta y_{t}=\mu \Delta g_{t}+w_{t} \frac{\partial l_{t}}{\partial r_{t}} \Delta r_{t},
$$

gdzie $\frac{\partial l_{t}}{\partial r_{t}}>0$ jest miarą międzyokresowej substytucji czasu wolnego.

Międzyokresowa substytucja czasu wolnego jest następstwem tego, że okres wyższych wydatków rządowych jest jednocześnie okresem relatywnie gorszej sytuacji gospodarstw domowych.

Wyższe wydatki rządowe oddziałują na decyzje gospodarstw domowych również poprzez wpływ na ich ogólny poziom bogactwa - sumę obecnego i zdyskontowanych przyszłych poziomów majątku ${ }^{28}$. W wyniku zmian wydatków rządowych zmiana zdyskontowanego poziomu majątku gospodarstw domowych $\left(\Delta \Omega_{t}\right)$ wynosi:

$$
\Delta \Omega_{t}=-(1-\mu-\gamma) \sum_{t=1}^{\infty} \hat{R}_{t} \Delta g_{t} .
$$

Zatem gdy spełniony jest warunek $\gamma+\mu<1$, wówczas obecny lub antycypowany przyszły wzrost wydatków rządowych prowadzi do obniżenia się zdyskontowanego poziomu majątku gospodarstw domowych ${ }^{29}$. Zakładając, że efektywna konsumpcja oraz podaż pracy są dobrami normalnymi uzyskuje się: $\frac{\partial c_{t}}{\partial \Omega_{t}}>0$, $\frac{\partial l_{t}}{\partial \Omega_{t}}<0$. W rezultacie wzrost wydatków rządowych prowadzi do zwiększenia się podaży pracy i ograniczenia konsumpcji.

Im bardziej długotrwała zmiana wydatków rządowych, tym negatywny efekt majątkowy w mniejszym stopniu oddziałuje przez substytucję czasu wolnego, a w większym poprzez wpływ na zdyskontowany majątek gospodarstw domowych. W przypadku trwałej zmiany wydatków rządowych międzyokresowa substytucja czasu wolnego nie występuje. Jeżeli zmiana wydatków rządowych jest trwała i wynosi $\Delta \bar{g}$, wówczas zmiana agregatowej podaży jest dana wzorem: wych.

${ }^{28}$ Miara ta w dalszej części określana jest jako zdyskontowany majątek gospodarstw domo-

${ }^{29} \mathrm{~W}$ analizie ukazującej oddziaływanie międzyokresowej substytucji czasu wolnego, w celu większej przejrzystości analizy, wpływ wydatków rządowych na zdyskontowany poziom majątku został pominięty. Wpływ ten jest nieznaczny przy przejściowym podwyższeniu wydatków rządowych, które jest bardzo krótkotrwałe. Natomiast z formalnego punktu widzenia oznacza to przyjęcie założenia: $\sum_{t=1}^{\infty} \hat{R}_{t} \Delta g_{t}=0$. 
$\Delta y_{t}^{s}=\mu \Delta \bar{g}+w_{t} \frac{\partial l_{t}}{\partial \Omega_{t}} \frac{\partial \Omega_{t}}{\partial \bar{g}} \Delta \bar{g}$

Natomiast zmiana efektywnej konsumpcji wynosi:

$$
\Delta c_{t}^{e}=\frac{\partial c_{t}}{\partial \Omega_{t}} \frac{\partial \Omega_{t}}{\partial \bar{g}} \Delta \bar{g}
$$

Uwzględniając równanie (35) otrzymuje się:

$$
\Delta y_{t}^{s}=\mu \Delta \bar{g}+w_{t} \frac{\partial l_{t}}{\partial \Omega_{t}}\left[-(1-\mu-\gamma) \sum_{t=1}^{\infty} \hat{R}_{t}\right] \Delta \bar{g}
$$

oraz:

$$
\Delta c_{t}^{e}=\frac{\partial c_{t}}{\partial \Omega_{t}}\left[-(1-\mu-\gamma) \sum_{t=1}^{\infty} \hat{R}_{t}\right] \Delta \bar{g} .
$$

W przypadku trwałej zmiany wydatków rządowych zmiana agregatowego popytu określona jest równaniem:

$\Delta y_{t}^{d}=\Delta c_{t}^{e}+(1-\gamma) \Delta \bar{g}$,

czyli nadwyżkowy popyt dany jest wzorem:

$$
\Delta e_{t}=\Delta c_{t}^{e}+(1-\gamma) \Delta \bar{g}-\Delta y_{t}^{s}
$$

Zatem, po podstawieniu równania (38) oraz równania (39) do równania (41), wzór na nadwyżkowy popyt przybiera postać:

$$
\begin{aligned}
& \Delta e_{t}=\frac{\partial c_{t}}{\partial \Omega_{t}}\left[-(1-\mu-\gamma) \sum_{t=1}^{\infty} \hat{R}_{t}\right] \Delta \bar{g}+ \\
& +(1-\gamma) \Delta g_{t}-\mu \Delta \bar{g}-w_{t} \frac{\partial l_{t}}{\partial \Omega_{t}}\left[-(1-\mu-\gamma) \sum_{t=1}^{\infty} \hat{R}_{t}\right] \Delta \bar{g},
\end{aligned}
$$

czyli:

$$
\Delta e_{t}=(1-\gamma-\mu) \Delta \bar{g}+\left(\frac{\partial c_{t}}{\partial \Omega_{t}}-w_{t} \frac{\partial l_{t}}{\partial \Omega_{t}}\right)\left[-(1-\mu-\gamma) \sum_{t=1}^{\infty} \hat{R}_{t}\right] \Delta \bar{g} .
$$

Powyższe równanie można uprościć do postaci:

$$
\Delta e_{t}=(1-\mu-\gamma)\left[1-\left(\frac{\partial c_{t}}{\partial \Omega_{t}}-w_{t} \frac{\partial l_{t}}{\partial \Omega_{t}}\right) \sum_{t=1}^{\infty} \hat{R}_{t}\right] \Delta \bar{g}
$$


Różniczkując ograniczenie budżetowe określone równaniem (27) względem $\Omega_{t}$ otrzymuje się:

$$
\sum_{t=1}^{\infty}\left[\frac{\partial c_{t}}{\partial \Omega_{t}}-w_{t} \frac{\partial l_{t}}{\partial \Omega_{t}}\right] \hat{R}_{t}=1 .
$$

Zakładając, że krańcowy produkt pracy jest stały w czasie oraz przyjmując, że siła efektu majątkowego w przypadku konsumpcji i czasu wolnego jest stała $\mathrm{W}$ czasie $^{30}$, równanie (45) można zapisać w postaci:

$$
\left(\frac{\partial c}{\partial \Omega}-w \frac{\partial l}{\partial \Omega}\right) \sum_{t=1}^{\infty} \hat{R}_{t}=1 .
$$

Wstawiając powyższe równanie do równania (44) uzyskuje się:

$$
\frac{\Delta e_{t}}{\Delta \bar{g}}=0 \text {. }
$$

Zatem trwały wzrost wydatków rządowych nie powoduje występowania nadwyżkowego popytu, a rynek dóbr i usług pozostaje w równowadze przy wyjściowej wysokości stopy procentowej.

W przypadku trwałego podwyższenia wydatków rządowych produkcja (wyznaczona z równania (40)) ulega zwiększeniu o następującą wielkość:

$$
\Delta y_{t}=1-\gamma+\frac{\partial c_{t}}{\partial \Omega_{t}} \frac{\partial \Omega_{t}}{\partial g_{t}} \Delta \bar{g}
$$

czyli:

$$
\Delta y_{t}=\left[1-\gamma-(1-\mu-\gamma) \sum_{t=1}^{\infty} \hat{R}_{t}\right] \Delta \bar{g} .
$$

Przy warunkach $(1-\mu-\gamma)>0, \gamma>0$ zachodzi zatem: $\frac{\Delta y_{t}}{\Delta \bar{g}}<1$, czyli wzrost produkcji jest mniejszy od wzrostu wydatków rządowych. Dobra dostarczane przez państwo stanowią bowiem substytut dóbr prywatnych, a ponadto następuje trwałe zmniejszenie wartości majątku gospodarstw domowych, co wpływa na ograniczenie poziomu konsumpcji.

Przyjmując, że występuje równowaga na rynku dóbr i rynku obligacji:

$$
c_{t}+i_{t}+g_{t}=y_{t},
$$

\footnotetext{
${ }^{30}$ Czyli przy następujących założeniach: $\frac{\partial c_{t}}{\partial \Omega_{t}}=\frac{\partial c}{\partial \Omega}, \frac{\partial l_{t}}{\partial \Omega_{t}}=\frac{\partial l}{\partial \Omega}, w_{t}=w$.
} 
$b_{t}+b_{t}^{g}=0$,

a także spełnione są warunki transwersalności wykluczające możliwość, by gospodarstwa domowe zwiększały obecną konsumpcję bez konieczności ograniczenia konsumpcji w przyszłości (por. np. McCandless, 2008):

$\lim _{t \rightarrow \infty} \beta^{t} u_{c, t} b_{t}=0$,

$\lim _{t \rightarrow \infty} \beta^{t} u_{c, t} k_{t}=0$,

gdzie: $u_{c, t}=\frac{\partial u\left(c_{t}, l_{t}, g_{t}\right)}{\partial c_{t}}$,

wyznaczyć można optymalne poziomy poszczególnych zmiennych. Na podstawie funkcji Lagrange'a otrzymuje następujące warunki maksymalizacji użyteczności:

$\frac{u_{c, t}}{u_{c, t+1}}=\beta\left[1+\left(1-\tau_{t+1}\right) r_{t+1}\right] \quad$ dla $t=1,2 \ldots$,

$\frac{u_{l, t}}{u_{c, t}}=-\left(1-\tau_{t}\right) w_{t} \quad \quad$ dla $t=1,2 \ldots$,

$r_{t}=\rho_{t}-\delta \quad$ dla $t=1,2 \ldots$,

gdzie:

$u_{l, t}=\frac{\partial u\left(c_{t}, l_{t}, g_{t}\right)}{\partial l_{t}}$.

$\mathrm{Z}$ równania (54) wynika, że gospodarstwa domowe tak dostosowują konsumpcję, aby krańcowa stopa substytucji pomiędzy konsumpcją obecną a przyszłą zrównywała się ze zdyskontowaną stopą zwrotu z obligacji (po opodatkowaniu). Warunek określony równaniem (55) oznacza, że krańcowa stopa substytucji pomiędzy czasem wolnym a konsumpcją zrównuje się z krańcowym produktem pracy (po opodatkowaniu). Natomiast równanie (56) wskazuje, że ilość kapitału kształtuje się na takim poziomie, dla którego stopa zwrotu z kapitału (uwzględniając deprecjację) zrównuje się ze stopą zwrotu z obligacji.

W stanie ustalonym gospodarka jest opisana przez następujące równania:

$$
\begin{aligned}
& -\frac{u_{l}^{*}}{u_{c}^{*}}=(1-\tau) w^{*}, \\
& \frac{1-\beta}{\beta}=(1-\tau) \rho^{*},
\end{aligned}
$$


$y^{*}=c^{*}+\delta k^{*}+g^{*}$,

gdzie:

$\rho^{*}=\frac{\partial f\left(k^{*}, l^{*}, g^{*}\right)}{\partial k^{*}}, w^{*}=\frac{\partial f\left(k^{*}, l^{*}, g^{*}\right)}{\partial l^{*}}, u_{l}^{*}=\frac{\partial u\left(c^{*}, l^{*}, g^{*}\right)}{\partial l^{*}}, u_{c}^{*}=\frac{\partial u\left(c^{*}, l^{*}, g^{*}\right)}{\partial c^{*}}$,

$l^{*}, k^{*}, g^{*}, c^{*}, y^{*}$ - wartości odpowiednio nakładu pracy, kapitału, wydatków rządowych, konsumpcji i produkcji w stanie ustalonym.

$\mathrm{Z}$ powyższych równań wynika, że w stanie ustalonym:

- krańcowa stopa substytucji pomiędzy konsumpcją a czasem wolnym zrównuje się z krańcowym produktem pracy po opodatkowaniu,

- konsumpcja jest niezmienna w czasie,

- inwestycje netto są równe zero.

Jeżeli wydatki rządowe nie wpływają na użyteczność i produkcję, wówczas krańcowe produkty i krańcowe użyteczności można zapisać następująco:

$w^{*}=\frac{\partial f\left(k^{*}, l^{*}\right)}{\partial l^{*}}, \rho^{*}=\frac{\partial f\left(k^{*}, l^{*}\right)}{\partial k^{*}}, u_{l}^{*}=\frac{\partial u\left(y^{*}-\delta k^{*}-g^{*}, l^{*}\right)}{\partial l^{*}}, u_{c}^{*}=\frac{\partial u\left(y^{*}-\delta k^{*}-g^{*}, l^{*}\right)}{\partial c^{*}}$.

W rezultacie równania (57)-(59) można przekształcić do postaci:

$-\frac{u_{l}^{*}\left(f\left(l^{*}, k^{*}\right)-\delta k^{*}-g^{*}, l^{*}\right)}{u_{c}^{*}\left(f\left(l^{*}, k^{*}\right)-\delta k^{*}-g^{*}, l^{*}\right)}=(1-\tau) \frac{\partial f\left(k^{*}, l^{*}\right)}{\partial l^{*}}$,

$\frac{1-\beta}{\beta}=(1-\tau) \frac{\partial f\left(k^{*}, l^{*}\right)}{\partial k^{*}}$.

W analizowanym przypadku, gdy wydatki rządowe stanowią drenaż zasobów z gospodarki, wzrost wydatków rządowych, poprzez negatywny efekt majątkowy, powoduje zwiększenie zatrudnienia oraz produkcji, a jednocześnie ograniczenie czasu wolnego i konsumpcji. Zatem kierunek oddziaływania wydatków rządowych na konsumpcję prywatną jest odmienny niż wynika to $\mathrm{z}$ większości badań empirycznych (por. np. Mountford, Uhlig, 2002; Perotti, 2002; Heppke-Falk, 2006; Gali, Lopez-Salido, Valles, 2007; Giordano i in., 2007) ${ }^{31}$. Szczegółową analizę zależności pomiędzy wydatkami rządowymi a konsumpcją prywatną w modelach RBC przedstawiają Bouakez i Rebei (2007). Wskazują oni, że wyjaśnieniem dodatniej zależności pomiędzy konsumpcją publiczną a prywatną może być komplementarność wymienionych rodzajów konsumpcji. W przypadku, gdy konsumpcja prywatna i publiczna są dobrami komplementarnymi model RBC gene-

\footnotetext{
${ }^{31}$ Warto przy tym zaznaczyć, że część badań empirycznych wskazuje na krótkookresowy ujemny wpływ wydatków rządowych na konsumpcję prywatną, por. Coenen, Straub (2005); Afonso, Sousa (2011).
} 
ruje bowiem, zgodnie z danymi empirycznymi, występowanie dodatniej korelacji pomiędzy wydatkami rządowymi a konsumpcją ${ }^{32}$.

Podwyższenie stopy podatkowej powoduje obniżenie zarówno produkcji, jak i konsumpcji. Wzrost opodatkowania zmniejsza krańcowy produkt z kapitału (po opodatkowaniu) przy początkowym poziomie kapitału i zatrudnienia. Aby przywrócić stan równowagi ilość kapitału ulega obniżeniu, tak by krańcowy produkt kapitału uległ zwiększeniu do początkowej wartości, określonej przez preferencje konsumpcji w czasie gospodarstw domowych (por. np. McGrattan, 1994; Ferroni, 2010). Wynikający z modelu RBC wpływ wzrostu opodatkowania na kształtowanie się zatrudnienia jest natomiast niejednoznaczny. Z jednej strony efekt substytucyjny prowadzi do obniżenia się zatrudnienia na rzecz czasu wolnego. $Z$ drugiej zaś efekt dochodowy związany z obniżeniem się kapitału i majątku gospodarstw domowych powoduje ograniczenie czasu wolnego i zwiększenie zatrudnienia.

\subsection{Wpływ stochastycznych zmian wydatków rządowych}

W pierwszych modelach realnego cyklu koniunkturalnego za jedyne źródło fluktuacji przyjmujących szoki technologiczne, występowała silna dodatnia korelacja pomiędzy zatrudnieniem i wydajnością pracy (por. Hansen, 1985; Hansen, Wright, 1992). W rzeczywistych gospodarkach korelacja pomiędzy liczbą przepracowanych godzin, wydajnością pracy i produkcją jest znacznie słabsza (por. np. Hansen, Wright, 1992; Rebelo, 2005; Kuchta, Piłat, 2010; McGrattan, Prescott, $2012)^{33}$. Zatem pierwsze modele RBC nie odwzorowywały poprawnie zależności pomiędzy tymi zmiennymi. Modele te, nie uwzględniając wpływu zmian w wydatkach rządowych, przyjmowały implicite, że konsumpcja prywatna i wydatki publiczne wywierają identyczny wpływ na użyteczność krańcową gospodarstw domowych. Jednak, jak wskazują Barro (1981) oraz Aschauer (1988), jeżeli na użyteczność gospodarstw domowych silniej wpływa konsumpcja prywatna niż publiczna, wówczas zmiany w wydatkach rządowych oddziałują na podaż pracy i produkcję. Wzrost wydatków rządowych powoduje wtedy zwiększenie się podaży pracy i zgodnie z prawem malejących przychodów zmniejszenie krańcowej produktywności pracy. W rezultacie występowanie wahań wydatków rządowych, w przypadku braku innych rodzajów szoków, implikować będzie ujemną korelację pomiędzy podażą pracy a wydajnością pracy (por. King, Rebelo, 2000). W ten

${ }^{32}$ Dodatnią zależność pomiędzy poziomem wydatków rządowych i konsumpcji prywatnej otrzymuje się również w modelach zakładających silną komplementarność konsumpcji i zatrudnienia (por. Bouakez, Rebei, 2007; Monacelli, Perottti, 2008).

${ }^{33}$ Przykładowo w gospodarce amerykańskiej od lat 90. XX w. korelacja pomiędzy odchyleniami wydajności pracy a odchyleniami produkcji od trendu jest jedynie nieznacznie wyższa od zera (por. McGrattan, Prescott, 2012). 
sposób wprowadzenie wahań wydatków rządowych osłabia dodatnią korelację pomiędzy wymienionymi zmiennymi wynikającą z występowania szoków technologicznych ${ }^{34}$.

Wpływ uwzględnienia szoków fiskalnych na poprawność odwzorowania przez modele RBC korelacji występujących pomiędzy rzeczywistymi zmiennymi makroekonomicznymi ukazuje model Christiano i Eichenbauma (1992). Analizują oni dwa przypadki wprowadzenia wydatków rządowych do modeli $\mathrm{RBC}$ - w oparciu o model z podzielną oraz niepodzielną pracą. W obydwu wersjach modelu zakłada się, podobnie jak u Aschauera (1988), że na efektywną konsumpcję wpływa zarówno konsumpcja prywatna, jak i publiczna (por. równanie (13)).

W modelu Christiano i Eichenbauma występują dwie zmienne stochastyczne - szoki technologiczne oraz szoki fiskalne dotyczące zmian wydatków rządowych. Wydatki rządowe określone są równaniem:

$\ln g_{t}=\ln \overline{g_{t}}+\ln z_{t}$,

gdzie:

$$
\begin{aligned}
\ln \overline{g_{t}} & =\left(1-\rho_{g}\right) \ln \bar{g}+\rho_{g} \ln \bar{g}_{t-1}+\varepsilon_{g, t}, \varepsilon_{g, t} \sim N\left(0, \sigma_{\varepsilon, g}{ }^{2}\right), \rho_{g} \in(-1,1), \\
\bar{g} & - \text { średni poziom } \overline{g_{t}} .
\end{aligned}
$$

Powyższa specyfikacja oznacza, że wysokość wydatków rządowych jest uzależniona od szoków technologicznych oraz szoków dotyczących polityki fiskalnej. Szoki technologiczne wpływają w tym przypadku na trwałe zmiany produkcji oraz wydatków rządowych. Natomiast szoki dotyczące polityki fiskalnej powodują przejściowe zmiany w wydatkach rządowych.

Przekształcając równanie (62) otrzymuje się:

$\overline{g_{t}}=\frac{g_{t}}{z_{t}}$.

Szok technologiczny, oddziałujący na trwałe zmiany wydatków rządowych, określa równanie:

$$
z_{t}=e^{\varepsilon_{z, t}} z_{t-1}, \varepsilon_{z, t} \sim N\left(0, \sigma_{\varepsilon, z}{ }^{2}\right) \text {. }
$$

W modelu funkcja produkcji jest zdefiniowana jako funkcja Cobba-Douglasa z postępem technicznym w sensie Harroda, czyli:

\footnotetext{
${ }^{34} \mathrm{Na}$ zmniejszenie korelacji pomiędzy liczbą przepracowanych godzin a wydajnością pracy w modelach RBC wpływa również uwzględnienie pracy na własny użytek, nierozdzielności czasu wolnego oraz uwzględnienie w kapitale wartości niematerialnych i prawnych (por. Benhabib, Rogerson, Wright; 1991; Hansen, Wright, 1992; McGrattan, Prescott, 2012).
} 
$y_{t}\left(z_{t}, k_{t}, l_{t}\right)=k_{t}^{\theta}\left(z_{t} l_{t}\right)^{1-\theta}$,

gdzie: $\theta \in(0,1)$.

W rezultacie, na podstawie powyższego równania, równania przyrostu kapitału oraz równania agregatowego popytu uzyskuje się:

$c_{t}=k_{t}^{\theta}\left(z_{t} l_{t}\right)^{1-\theta}-g_{t}-k_{t+1}+(1-\delta) k_{t}$.

W przypadku podzielnej pracy gospodarstwa domowe maksymalizują następującą wartość oczekiwaną sumy zdyskontowanych użyteczności:

$U=E\left(\sum_{t=0}^{\infty} \beta^{t}\left\{\ln c^{e}+A \ln \left(H-l_{t}\right)\right\}\right)$.

Uwzględniając równania (13) oraz (67) otrzymuje się:

$U=E\left(\sum_{t=0}^{\infty} \beta^{t}\left\{\ln \left(k_{t}^{\theta}\left(z_{t} l_{t}\right)^{1-\theta}-g_{t}-k_{t+1}+(1-\delta) k_{t}+\gamma g_{t}\right)+A \ln \left(H-l_{t}\right)\right\}\right)$,

Powyższe równanie uprościć można do postaci:

$U=E\left(\sum_{t=0}^{\infty} \beta^{t}\left\{\ln \left(k_{t}^{\theta}\left(z_{t} l_{t}\right)^{1-\theta}-k_{t+1}+(1-\delta) k_{t}+(\gamma-1) g_{t}\right)+A \ln \left(H-l_{t}\right)\right\}\right)$,

po przekształceniach uzyskując:

$U=E\left(\sum_{t=0}^{\infty} \beta^{t}\left\{\ln \left(e^{-\theta \varepsilon_{z, t}} l_{t}^{1-\theta} \bar{k}_{t}^{\theta}+e^{-\varepsilon_{z, t}}(1-\theta) \bar{k}_{t}-\bar{k}_{t+1}+(\gamma-1) \bar{g}_{t}\right)+A \ln \left(H-l_{t}\right)\right\}\right)+$

$+E \sum_{t=0}^{\infty} \beta^{t} \ln z_{t}$

gdzie: $\overline{c_{t}}=\frac{c_{t}}{z_{t}}, \overline{y_{t}}=\frac{y_{t}}{z_{t}}, \overline{k_{t}}=\frac{k_{t}}{z_{t}}$.

Powyższe wyrażenie można zapisać następująco:

$U=E\left(\sum_{t=0}^{\infty} \beta^{t}\left\{\ln \left(e^{-\theta \varepsilon_{z, t}} l_{t}^{1-\theta} \bar{k}_{t}^{\theta}+e^{-\varepsilon_{z, t}}(1-\theta) \bar{k}_{t}-\bar{k}_{t+1}+(\gamma-1) \bar{g}_{t}\right)+A V\left(H-l_{t}\right)\right\}\right)+\kappa$

gdzie:

$\kappa=E \sum_{t=0}^{\infty} \beta^{t} \ln z_{t}$,

czyli $\kappa$ nie jest uzależnione od decyzji gospodarstw domowych i nie wpływa na zachowanie gospodarstw domowych. 
W przypadku wersji modelu z niepodzielną pracą funkcja użyteczności jest dana wzorem:

$$
U=E\left(\sum_{t=0}^{\infty} \beta^{t}\left\{\ln c^{e}+A\left(H-l_{t}\right)\right\}\right) .
$$

Po przekształceniach, analogicznie jak w wariancie z podzielną pracą, otrzymuje się:

$$
\begin{aligned}
& U=E\left(\sum _ { t = 0 } ^ { \infty } \beta ^ { t } \left\{\ln \left(e^{-\theta \varepsilon_{z, t}} l_{t}^{1-\theta} \bar{k}_{t}^{\theta}+e^{-\varepsilon_{z, t}}(1-\theta) \bar{k}_{t}-\bar{k}_{t+1}+(\gamma-1) \bar{g}_{t}\right)+\right.\right. \\
& \left.\left.+A\left(H-l_{t}\right)\right\}\right)+\kappa
\end{aligned}
$$

Rozwiązanie analityczne powyższych problemów maksymalizacyjnych jest możliwe jedynie w przypadku wersji modelu z podzielną pracą, dla $\gamma, \delta=1$. W pozostałych przypadkach rozwiązanie można otrzymać jedynie metodą symulacyjną. Christiano i Eichenbaum stosują rozwiązanie numeryczne opierając się na metodologii zastosowanej przez Kydlanda i Prescotta (1982).

Otrzymane rozwiązanie przyjmuje następującą postać:

$$
\begin{aligned}
& \bar{k}_{t+1}=\bar{k}\left(\frac{\bar{k}_{t}}{\bar{k}}\right)^{r_{k}}\left(\frac{\bar{g}_{t}}{\bar{g}}\right)^{d_{k}} e^{e_{k}\left(\varepsilon_{z, t}-\varepsilon_{z}\right)}, \\
& \bar{l}_{t}=\bar{l}\left(\frac{\bar{k}_{t}}{\bar{k}}\right)^{r_{l}}\left(\frac{\bar{g}_{t}}{\bar{g}}\right)^{d_{l}} e^{e_{l}\left(\varepsilon_{z, t}-\varepsilon_{z}\right)},
\end{aligned}
$$

gdzie $\overline{l_{t}}=\frac{l_{t}}{z_{t}}, \bar{k}$ oraz $\bar{l}$ oznaczają średnie wartości odpowiednio kapitału i pracy, natomiast parametry $r_{k}, d_{k}, e_{k}, r_{l}, d_{l}, e_{l}$ są funkcjami parametrów strukturalnych modelu.

Christiano i Eichenbaum szacują parametry strukturalne modelu na podstawie danych dla gospodarki amerykańskiej. Następnie, w oparciu o oszacowane parametry za pomocą metod symulacyjnych, określane są wariancje zmiennych i korelacje pomiędzy zmiennymi. Z symulacji tych wynika, że wprowadzenie do modelu RBC stochastycznych zmian w wydatkach rządowych wpływa na lepsze odwzorowanie przez model zależności makroekonomicznych (por. też Cooper, 1997). W szczególności na podstawie symulacji przeprowadzonych przez Christiano i Eichenbauma otrzymuje się, że wprowadzenie wydatków rządowych obniża korelację pomiędzy liczbą przepracowanych godzin a wydajnością pracy, przybliżając oszacowaną korelację do wielkości występujących w rzeczywistych 
gospodarkach ${ }^{35}$. Warto jednocześnie zauważyć, że występowanie jedynie szoków wynikających z wahań wydatków rządowych generowałoby dane niezgodne z rzeczywistymi danymi, ponieważ skutkowałoby ujemną korelacją pomiędzy podażą pracy a wydajnością pracy (por. Hansen, Wright, 1992; King, Rebelo, 2000).

Podsumowując, z modelu przedstawionego przez Christiano i Eichenbauma (1992) wynika, że wprowadzenie dodatkowego źródła szoków w postaci zmian wydatków rządowych wpływa na lepsze odwzorowanie przez model zależności makroekonomicznych niż przez wcześniejsze modele RBC, w których jedyne źródło szoków stanowiły szoki technologiczne. Uwzględnienie wydatków rządowych obniża korelację pomiędzy liczbą przepracowanych godzin a wydajnością pracy, przybliżając uzyskane wartości do wielkości występujących w realnych gospodarkach. Wpływ uwzględnienia wydatków rządowych na lepsze odwzorowanie zależności pomiędzy zatrudnieniem a wydajnością pracy potwierdzają również inne modele RBC (por. m.in. Fairise, Langot, 1994; Rebelo, 2005).

\subsection{Oddziaływanie deterministycznych zmian w polityce fiskalnej}

Jak wynika z modelu Christiano i Eichenbauma (1992), uwzględnienie w modelu RBC stochastycznych szoków fiskalnych polepsza właściwości statystyczne modelu, głównie dotyczące korelacji pomiędzy zatrudnieniem a wydajnością pracy. Baxter i King (1993) analizie poddali natomiast wpływ deterministycznych zmian $\mathrm{w}$ polityce fiskalnej na kształtowanie się zmiennych makroekonomicznych, m.in. produkcji, konsumpcji, inwestycji oraz zatrudnienia. Na podstawie podażowego modelu RBC Baxter i King zbadali skutki zarówno trwałego, jak i przejściowego zwiększenia wydatków rządowych. Model Baxter i Kinga stanowi rozwinięcie modelu przedstawionego przez Barro (1989), w którym nakład kapitału może ulegać zmianie, jednak wielkość zatrudnienia jest ustalona na stałym poziomie. Natomiast Baxter i King uwzględniają, że gospodarstwa domowe mogą zmieniać zarówno nakład kapitału, jak i pracy.

W modelu analizowane są dwie możliwości reakcji polityki fiskalnej na zmianę poziomu wydatków rządowych: dostosowanie poziomu podatków uzależnionych od wielkości produkcji lub płatności transferowych ${ }^{36}$. Oprócz oszacowania podażowych efektów bieżących wydatków rządowych Baxter i King

${ }^{35}$ Zarówno w wariancie modelu z podzielną pracą, jak i z pracą niepodzielną.

${ }^{36} \mathrm{~W}$ modelu explicite nie jest brane pod uwagę występowanie deficytu budżetowego i długu publicznego, jednak zgodnie z ekwiwalencją ricardiańską przedstawioną przez Barro (1974) zmiany w płatnościach transferowych (lub zryczałtowanych podatkach) są ekwiwalentne z finansowaniem wydatków budżetowych za pomocą długu publicznego (szerzej na tent temat por. Krawczyk, 2007). Zatem przedstawione w modelu wnioski mają również zastosowanie w przypadku występowania deficytu budżetowego i długu publicznego. 
badają również wpływ publicznych wydatków kapitałowych na kształtowanie się poszczególnych zmiennych makroekonomicznych.

Model Baxter i Kinga opiera się na następujących założeniach:

1. Na wydatki publiczne $\left(E_{t}^{G}\right)$ składają się bieżące i inwestycyjne wydatki rządowe oraz transfery:

$E_{t}^{G}=g_{t}^{B}+i_{t}^{G}+T r_{t}$,

gdzie:

$g_{t}^{B}$ - bieżące wydatki rządowe na zakup dóbr i usług,

$i_{t}^{G}$ - inwestycyjne wydatki rządowe,

$T r_{t}$ - zryczałtowane płatności transferowe dla gospodarstw domowych.

2. Dochody publiczne $\left(R_{t}^{G}\right)$ składają się jedynie z podatków niezryczałtowanych (distortionary taxation), których wysokość uzależniona jest od poziomu dochodu:

$R_{t}^{G}=\tau_{t} y_{t}$.

3. W każdym okresie budżet jest zrównoważony, czyli uwzględniając równania (78) oraz (79) zachodzi:

$\tau_{t} y_{t}=g_{t}^{B}+i_{t}^{G}+T r_{t}$.

4. Gospodarstwa domowe maksymalizują sumę zdyskontowanych użyteczności postaci:

$U=E\left(\sum_{t=1}^{\infty} \beta^{t-1}\left[\ln \left(c_{t}\right)+A \ln \left(h_{t}\right)+\Gamma\left(g_{t}^{B}, k_{t}^{G}\right)\right]\right)$,

gdzie:

$k_{t}^{G}-$ zasób kapitału dostarczanego przez państwo,

$A>0, \frac{\partial \Gamma}{\partial g_{t}^{B}} \geq 0, \frac{\partial \Gamma}{\partial k_{t}^{G}} \geq 0$.

Wydatki rządowe i kapitał publiczny nie wpływają zatem na krańcową użyteczność z konsumpcji (por. Kamps, 2004).

5. W każdym z okresów gospodarstwo domowe stoi przed dwoma ograniczeniami:

- suma czasu wolnego i pracy nie może przekraczać całkowitego zasobu czasu (znormalizowanego w modelu do jedności):

$h_{t}+l_{t} \leq 1$

- suma wydatków konsumpcyjnych i inwestycyjnych gospodarstw domowych nie może przekraczać dochodu do dyspozycji: 
$c_{t}+i_{t} \leq\left(1-\tau_{t}\right) y_{t}+T r_{t}$,

6. Wielkość produkcji jest uzależniona od nakładów kapitału prywatnego, kapitału publicznego i pracy (por. np. Bukowski i in., 2005):

$y_{t}=f\left(k_{t}, k_{t}^{G}, l_{t}\right)$.

Baxter i King przyjmują funkcję produkcji postaci:

$y_{t}=k_{t}^{\theta}\left(k_{t}^{G}\right)^{\theta_{k G}} l_{t}^{1-\theta}$,

gdzie: $\theta \in(0,1), \theta_{k G}>0$.

Zatem analizowaną funkcję cechują stałe efekty skali względem kapitału prywatnego i nakładu pracy. W modelu kapitał publiczny oddziałuje na możliwości wytwórcze, natomiast wydatki rządowe nie wpływają na krańcową produktywność prywatnych czynników produkcji (por. Kamps, 2004).

7. Zasób kapitału prywatnego zmienia się zgodnie z typowym równaniem przyrostu kapitału, określonym równaniem (7).

8. Analogiczna sytuacja występuje w przypadku kapitału dostarczanego przez państwo, którego zasób określa następujące równanie:

$k_{t+1}^{G}=(1-\delta) k_{t}^{G}+i_{t}^{G}$.

9. Łączny popyt $\mathrm{w}$ gospodarce nie może przekraczać wielkości produkcji:

$c_{t}+i_{t}+g_{t}^{B}+i_{t}^{G} \leq y_{t}$.

Przeprowadzona przez Baxter i Kinga analiza wpływu polityki fiskalnej na produkcję i pozostałe zmienne makroekonomiczne opiera się na metodach numerycznych. Parametry w modelu są skalibrowane w taki sposób, by charakterystyki zmiennych zastosowanych w modelu odpowiadały charakterystykom rzeczywistych zmiennych $\mathrm{w}$ gospodarce amerykańskiej po II wojnie światowej.

Na podstawie modelu analizowane są skutki następujących czterech rodzajów nieoczekiwanych szoków fiskalnych ${ }^{37}$ :

- trwałego zwiększenia wydatków rządowych finansowanych niższymi płatnościami transferowymi,

- przejściowego zwiększenia wydatków rządowych finansowanych niższymi płatnościami transferowymi,

- trwałego zwiększenia wydatków rządowych finansowanych podatkami proporcjonalnymi do wielkości produkcji,

\footnotetext{
${ }^{37}$ Oddziaływanie oczekiwanych zmian fiskalnych analizują m.in. Ljungqvist i Sargent (2004).
} 
- trwałego zwiększenia inwestycyjnych wydatków rządowych finansowanych niższymi płatnościami transferowymi ${ }^{38}$.

$\mathrm{Z}$ modelu wynika, że trwałe zwiększenie wydatków rządowych finansowanych niższymi płatnościami transferowymi poprzez negatywny efekt majątkowy powoduje obniżenie konsumpcji i czasu wolnego oraz zwiększenie podaży pracy. Ponieważ wzrost zatrudnienia przesuwa krzywą krańcowego produktu kapitału w górę, rośnie więc pożądany zasób kapitału. W okresie dostosowawczym następuje silne zwiększenie inwestycji prowadzące do szybkiej konwergencji kapitału do poziomu docelowego. Gospodarka zmierza do nowego stanu ustalonego z wyższym poziomem kapitału i pracy. Jednocześnie w nowym stanie ustalonym stosunek kapitału do pracy pozostaje na wyjściowym poziomie. Z symulacji przeprowadzonych przez Baxter i Kinga wynika, że trwałe podniesienie wydatków rządowych o $1 \%$ PKB prowadzi do wzrostu PKB w gospodarce amerykańskiej o ok. 1,2\% ${ }^{39}$. W początkowym okresie (zanim nastąpi dostosowanie się ilości kapitału) wzrost PKB jest w głównej mierze spowodowany zwiększeniem się podaży pracy. W wyniku zmiany podaży pracy, przy niezmienionym poziomie kapitału, spada krańcowy produkt pracy i maleje stawka płac. Z drugiej strony wyższa podaż pracy powoduje wzrost krańcowego produktu kapitału i podwyższenie się stopy procentowej. W okresie dostosowawczym, wraz ze zwiększaniem się ilości kapitału, rośnie krańcowy produkt pracy i maleje krańcowy produkt kapitału. Obniżeniu ulega zatem stopa procentowa, a rośnie stawka płac. W długim okresie stopa procentowa i stawka płac zbiegają do wyjściowego poziomu ${ }^{40}$.

Oprócz trwałego wzrostu wydatków rządowych Baxter i King analizują również przejściowy wzrost wydatków rządowych, finansowanych niższymi płatnościami transferowymi. Baxter i King badają wpływ nieoczekiwanego wzrostu wydatków rządowych o $1 \%$ PKB, trwającego cztery okresy. Czteroletni okres zwiększonych wydatków rządowych autorzy interpretują jako okres zwiększonych wydatków rządowych w okresie trwania wojny. Z symulacji wynika, że w okresie utrzymywania się zwiększonych wydatków rządowych następuje obniżenie konsumpcji, czasu wolnego i inwestycji. Obniżenie się wymienionych wielkości

${ }^{38} \mathrm{~W}$ modelu przyjęto, że zryczałtowaną wielkością budżetową dostosowywaną w odpowiedzi na zmiany wydatków rządowych są płatności transferowe. Analogiczne wyniki otrzymuje się przy założeniu, że zmiany wydatków rządowych są finansowane zryczałtowanymi podatkami.

${ }^{39}$ Wyniki uzyskane przez Baxter i Kinga wskazują na silniejszy, niż wcześniejsze badania, wpływ trwałego wzrostu wydatków rządowych na kształtowanie się produkcji. Np. według Barro (1981) trwały wzrost wydatków rządowych o 1\% PKB podnosi produkcję o ok. 0,5\%. Przy czym oszacowania Barro opierają się na modelu, w którym nie następują zmiany podaży pracy (por. też Barro, 1989), zatem nie dochodzi do krótkookresowej zmiany stopy procentowej w wyniku wzrostu zatrudnienia prowadzącego do podniesienia się krańcowego produktu kapitału.

${ }^{40}$ Podobne zależności występują w przypadku oczekiwanych zmian wydatków rządowych (por. Ljungqvist i Sargent, 2004). 
jest efektem absorpcji zasobów z gospodarki przez państwo. Zmniejszenie się inwestycji w przejściowym okresie zwiększonych wydatków rządowych ma na celu wygładzenie wahań konsumpcji - następuje przesunięcie środków z inwestycji na konsumpcję, tak by nie dopuścić do gwałtownego obniżenia się konsumpcji w przejściowym okresie drenażu zasobów z gospodarki. Po okresie wojny następuje nieznaczny wzrost inwestycji, mający na celu odbudowanie ilości kapitału, a konsumpcja i czas wolny przez okres dostosowawczy kształtują się poniżej poziomu sprzed szoku, zbiegając do poziomu wyjściowego. Główna różnica pomiędzy kształtowaniem się zmiennych makroekonomicznych w przypadku przejściowego i trwałego wzrostu wydatków rządowych dotyczy inwestycji. Przy trwałym wzroście wydatków rządowych inwestycje kształtują się na poziomie wyższym od poziomu wyjściowego. Natomiast w przypadku szoku przejściowego w okresie wyższych wydatków rządowych nakłady inwestycyjne są niższe - inwestycje są „przejadane”, tak by wygładzić wahania konsumpcji. Na skutek przejściowej zmiany wydatków rządowych w okresie szoku zmianie ulegają ceny czynników produkcji. Stawka płac ulega obniżeniu, natomiast stopa procentowa wzrasta. W okresie dostosowywania się gospodarki po szoku, stawka płac oraz stopa procentowa stopniowo powracają do wyjściowego poziomu.

W przypadku szoku przejściowego wzrost produkcji w pierwszym roku po szoku jest mniejszy niż w przypadku szoku trwałego ${ }^{41}$. Zgodnie z symulacjami Baxter i Kinga w wyniku przejściowego zwiększenia wydatków rządowych o $1 \%$ PKB produkcja początkowo rośnie o ok. $0,6 \%{ }^{42}$. Ponadto w przypadku szoku przejściowego w kolejnych latach od wystąpienia szoku kształtowanie się produkcji jest odmienne niż w przypadku szoku trwałego. Przejściowa zmiana wydatków sprawia, że w kolejnych latach trwania szoku produkcja ulega stopniowemu obniżeniu, osiągając wartość poniżej poziomu wyjściowego tuż po zakończeniu szoku. Obniżenie produkcji poniżej poziomu wyjściowego wynika z niższego poziomu kapitału. Po zakończeniu się szoku kapitał zostaje stopniowo odbudowywany, powracając do wyjściowego poziomu, a wraz z nim do poziomu sprzed wystąpienia szoku zbiega również produkcja. Natomiast w przypadku trwałego wzrostu wydatków rządowych produkcja przez cały czas stopniowo rośnie, asymptotycznie zbiegając do poziomu długookresowego.

${ }^{41}$ Podobne wyniki otrzymali m.in. Devereux, Head i Lapham (1996) (szerzej na ten temat por. Hemming, Kell, Mahfouz, 2002). Wyniki otrzymane przez Baxter i Kinga, wskazujące, że przejściowy wzrost wydatków rządowych wywiera mniejszy wpływ na produkcję niż trwały wzrost wydatków rządowych, są natomiast odmienne od wcześniejszych wyników, otrzymanych przez Barro (1981).

${ }^{42}$ Nowsze badania wskazują przy tym, że siła podażowego oddziaływania trwałego zwiększenia wydatków rządowych uzależniona jest w znacznym stopniu od założeń dotyczących ryzyka związanego z inwestowaniem. Z analizy, którą przeprowadzili Angeletos i Panousi (2009) wynika, że przy występowaniu ryzyka inwestycyjnego podażowy efekt wzrostu wydatków rządowych jest znacznie słabszy. 
Oszacowana przez Baxter i Kinga siła oddziaływania na produkcję zarówno przejściowych, jak i trwałych zmian wydatków rządowych mieści się w przedziale oszacowań uzyskiwanych na podstawie wektorowej autoregresji. Jak wskazują Baum i Koester (2011) w większości badaniach krótkookresowe mnożniki fiskalne w ujęciu bezwzględnym kształtują się pomiędzy 0,2 a 2,0 (por. też Afonso, Sousa, 2009; Hall, 2009; Coenen i in., 2010) ${ }^{43}$.

Przedstawione powyżej oddziaływanie polityki fiskalnej na PKB dotyczy przypadku, w którym, w celu utrzymania równowagi budżetowej, zmianie poziomu wydatków rządowych towarzyszy dostosowanie płatności transferowych. Do odmiennych wniosków dochodzi się, gdy zmiany wydatków rządowych są finansowane niezryczałtowanymi podatkami, tj. podatkami uzależnionymi od wielkości produkcji. W tym przypadku transfery są ustalone na stałym poziomie, a stopa podatkowa jest co roku określana w taki sposób, by zrównoważyć budżet. Zatem stopa podatkowa jest uzależniona od zmian wydatków rządowych, tj. dana wzorem:

$\tau_{t}=\frac{\left(g_{t}+r T_{t}\right)}{y_{t}}$.

W przypadku wzrostu wydatków rządowych, aby zrównoważyć budżet, nastąpić musi podwyżka stopy podatkowej. Gdyby wysokość stopy podatkowej nie oddziaływała na podaż pracy i inwestycje, niezbędna zmiana stopy podatkowej wynosiłaby:

$\Delta \tau_{t}=\frac{\Delta g_{t}}{y_{t}}$

Jednak ze względu na to, że wzrost stopy podatkowej negatywnie oddziałuje na skłonność gospodarstw domowych do inwestowania i pracy, następuje zmniejszenie się bazy podatkowej. W efekcie, w celu zrównoważenia budżetu, stopa

${ }^{43}$ Przykładowo, dla gospodarki amerykańskiej na podstawie wektorowej autoregresji Blanchard i Perotti (2002) uzyskali mnożnik wydatków rządowych równy 0,9, Mountford i Uhlig (2002) - 0,65, Gali, Lopez-Salido i Valles (2007) - 0,41, Perotti (2007) - 0,7, natomiast Ramey (2008) - 0,3. Dla poszczególnych krajów wartości mnożników mogą być przy tym odmienne (por. Lubiński, 2010). Ponadto badania oparte na modelowaniu przełącznikowym wskazują, że w okresie recesji mnożniki fiskalne mogą być większe niż o okresie ożywienia gospodarczego. Jak wynika z pracy Auerbacha i Gorodnichenki (2011) w gospodarce amerykańskiej w okresie ożywienia gospodarczego mnożniki fiskalne nie przekraczają 0,5 , natomiast w okresie recesji - mieszczą się w przedziale 1,0-1,5. Potwierdzają to oszacowania Romera i Bernsteina (2009), według których fiskalne działania stymulacyjne w okresie kryzysu cechują się mnożnikiem fiskalnym wyższym od jedności. Również wyniki badań, które przedstawiają Afonso, Baxa i Slavík (2011), ukazują, że w okresie ostatniego kryzysu mnożniki fiskalne w większości krajów uległy zwiększeniu. Szczegółowy przegląd szacunków mnożników fiskalnych przed pojawieniem się kryzysu i w czasie jego trwania prezentuje Krzak (2012). 
podatkowa musi wzrosnąć bardziej niż wynika to z równania (89). Następuje zatem działanie mnożnikowe - wzrost stopy podatkowej pomniejsza bazę podatkową, co z kolei wymusza dalsze podwyższenie opodatkowania i obniżenie się bazy podatkowej.

Przy założeniu, że podaż pracy jest stała, zmiana bazy podatkowej (wielkości produkcji) wynikająca z podwyższenia opodatkowania o wielkość określoną równaniem (89) jest dana wzorem postaci:

$\Delta y_{t}=-\frac{\theta}{1-\theta-\tau_{t}} \Delta g_{t}$.

Zmiana produkcji określona powyższym równaniem jest ujemna (czyli podwyższenia stopy podatkowej powoduje ograniczenie bazy podatkowej) dla: $1-\theta-\tau_{t}>0$. Jak wskazują Baxter i King, w gospodarce amerykańskiej powyższy warunek jest spełniony.

Aby sfinansować wzrost wydatków budżetowych, spełniony musi być warunek:

$\Delta R_{t}^{G}=\Delta g_{t}$,

a procentowa zmiana wpływów podatkowych uzależniona jest od procentowych zmian stopy podatkowej i bazy podatkowej:

$\frac{\Delta R_{t}^{G}}{R_{t}^{G}}=\frac{\Delta \tau_{t}}{\tau_{t}}+\frac{\Delta y_{t}}{y_{t}}$,

a zatem w przypadku analizowanego wariantu polityki fiskalnej zachodzi zależność:

$\frac{\Delta \tau_{t}}{\tau_{t}}+\frac{\Delta y_{t}}{y_{t}}=\frac{\Delta g_{t}}{\tau_{t} y_{t}}$.

Przekształcając powyższe równanie uzyskuje się, że niezbędna zmiana stopy podatkowej w celu zrównoważenia budżetu jest określona wzorem:

$\Delta \tau_{t}=\frac{\Delta g_{t}}{y_{t}}-\tau_{t} \frac{\Delta y_{t}}{y_{t}}$.

Podstawiając do równania (94) równanie określające zmianę bazy podatkowej (tj. równanie (90)) otrzymuje się:

$\Delta \tau_{t}=\frac{\Delta g_{t}}{y_{t}}-\tau_{t} \frac{-\frac{\theta}{1-\theta-\tau_{t}} \Delta g_{t}}{y_{t}}$, 
czyli po przekształceniu:

$\Delta \tau_{t}=\left(1+\tau_{t} \frac{\theta}{1-\theta-\tau_{t}}\right) \frac{\Delta g_{t}}{y_{t}}$.

Kurczenie się bazy podatkowej na skutek wzrostu stopy podatkowej powoduje zatem, że w celu sfinansowania wydatków podniesienie stopy podatkowej musi być wyższe niż w przypadku, gdyby stopa podatkowa nie oddziaływała na wielkość bazy podatkowej.

Przy założonej początkowej stopie podatkowej wynoszącej 20\% Baxter i King otrzymali, że w wyniku trwałego wzrostu wydatków rządowych o 1\% PKB, finansowanych podatkami zależnymi od dochodu, następuje obniżenie produkcji o 1,1\%. Jak wskazuje Ludvigson (1996) również przejściowe zwiększenie wydatków rządowych finansowane wyższą stopą podatkową prowadzi do ograniczenia produkcji. Podażowe efekty polityki fiskalnej są zatem w przypadku finansowania wydatków rządowych podatkami niezryczałtowanymi całkowicie odmienne niż w sytuacji równoważenia budżetu przez zmiany płatności transferowych, gdzie wzrost wydatków rządowych przekładał się na znaczny wzrost produkcji (por. też Cooper, 1997; Hemming, Kell, Mahfouz, 2002).

W powyższej analizie nie był uwzględniany fakt, że zmiana opodatkowania może wpływać nie tylko na pożądany zasób kapitału, ale również na podaż pracy. Zmiana opodatkowania oddziałuje na podaż pracy dwojako: wywiera efekt substytucyjny oraz dochodowy. W przypadku funkcji użyteczności opisanej wzorem (81) efekt substytucyjny jest równy efektowi dochodowemu, jeżeli wartość początkowych transferów wynosi zero. W takim przypadku zmiana stopy podatkowej nie oddziałuje na podaż pracy. Jeżeli jednak wartość początkowych transferów jest dodatnia, wtedy zmiana opodatkowania oddziałuje na podaż pracy. Im wyższa wartość transferów, tym silniejszy jest negatywny wpływ wzrostu wydatków rządowych finansowanych niezryczałtowanymi podatkami na PKB. Z oszacowań Baxter i Kinga wynika, że dla początkowej wartości transferów równej 10\% PKB zwiększenie wydatków rządowych sfinansowane podwyżką niezryczałtowanych podatków o $1 \%$ PKB powoduje ograniczenie produkcji o ponad 2,5\%. Baxter i King, oprócz podażowych efektów zmian bieżących wydatków rządowych, badają również oddziaływanie zmian w poziomie inwestycyjnych wydatków rządowych na kształtowanie się produkcji ${ }^{4}$. W modelu analizowany jest wpływ trwałego zwiększenia publicznych wydatków inwestycyjnych, finansowanego poprzez zmianę poziomu płatności transferowych.

Oddziaływanie publicznych wydatków inwestycyjnych na produkcję jest uzależnione od następujących czynników:

\footnotetext{
${ }^{44}$ Oddziaływanie publicznych wydatków inwestycyjnych w modelu RBC ukazują również prace Amheda i Yoo (1995) oraz Ohaniana (1997).
} 
- wpływu zwiększenia ilości dostarczanego przez państwo kapitału na produkcję,

- oddziaływania publicznych wydatków inwestycyjnych na kształtowanie się podaży pracy i kapitału prywatnego.

Baxter i King analizują wpływ zwiększenia inwestycyjnych wydatków rządowych przy założeniu, że ich wyjściowy poziom wynosi 5\% PKB oraz $\theta_{k G}=0,05$. Przy założonych parametrach wzrost publicznych nakładów inwestycyjnych o $1 \%$ PKB, poprzez zwiększenie ilości dostarczanego przez państwo kapitału, bezpośrednio zwiększa produkcję również o $1 \%{ }^{45}$. Główny kanał oddziaływania publicznych wydatków inwestycyjnych na kształtowanie się produkcji odbywa się przy tym poprzez wpływ na podaż pracy i poziom kapitału prywatnego. Po uwzględnieniu indukowanego przez podwyższenie publicznych nakładów inwestycyjnych wzrostu nakładów pracy i kapitału prywatnego okazuje się, że całkowita produkcja ulega zwiększeniu o ok. 2,6\%. Zmiany zatem publicznych nakładów inwestycyjnych powodują znaczny wzrost produkcji, odbywający się w pewnym stopniu poprzez bezpośredni wpływ kapitału publicznego na produkcję, ale przede wszystkim jednak poprzez oddziaływanie publicznych inwestycji na poziom prywatnych czynników produkcji (szerzej na temat wpływu kapitału publicznego w modelu RBC por. Kamps, 2004).

Podsumowując, Baxter i King analizują następujące szoki dotyczące wydatków rządowych:

- zmiany wydatków rządowych finansowane płatnościami transferowymi,

- zwiększenie wydatków rządowych finansowanych podatkami proporcjonalnymi do wielkości produkcji,

- podniesienie inwestycji publicznych.

Z przeprowadzonych przez Baxter i Kinga symulacji wynika, że:

- trwałe zwiększenie wydatków rządowych, któremu towarzyszy obniżenie płatności transferowych (lub podniesienie zryczałtowanych podatków) powoduje mnożnikowe zwiększenie produkcji,

- finansowany w analogiczny sposób przejściowy wzrost wydatków rządowych wywiera znacznie słabszy wpływ na produkcję,

- wzrost wydatków rządowych, finansowany podatkami proporcjonalnymi do wielkości dochodu, prowadząc do wzrostu stopy podatkowej powoduje ograniczenie produkcji,

- publiczne wydatki inwestycyjne w istotny sposób dodatnio wpływają na produkcję i inwestycje prywatne.

${ }^{45}$ Jeżeli bowiem stopa inwestycyjnych wydatków rządowych równa się parametrowi $\theta_{k G}$, wówczas wzrost inwestycyjnych wydatków rządowych o jednostkę, przy niezmiennych nakładach kapitału i pracy, powoduje analogiczny wzrost produkcji. W rezultacie, przy niezmienionych nakładach prywatnych czynników produkcji, wzrost inwestycyjnych wydatków rządowych nie zmienia w tym przypadku wielkości produkcji pozostającej do dyspozycji gospodarstw domowych. 
Zatem, jeżeli nie następują dostosowania dotyczące stóp podatkowych, wówczas trwałe podniesienie wydatków rządowych wywiera silny, większy niż w sytuacji zmiany przejściowej, dodatni wpływ na produkcję. Oddziaływanie to jest szczególnie silne w przypadku inwestycyjnych wydatków rządowych. Natomiast do zupełnie odmiennych wniosków prowadzą wyniki symulacji dotyczących wpływu wydatków rządowych finansowanych z podatków niezryczałtowanych, uzależnionych od wielkości dochodu. Jeśli bieżące wydatki rządowe są finansowane takimi podatkami, wówczas wzrost wydatków rządowych przekłada się na znaczne ograniczenie produkcji.

\subsection{Analiza niezryczałtowanych podatków nakładanych na czynniki produkcji}

W przedstawionych dotychczas modelach zakładano występowanie jednakowego opodatkowania kapitału i pracy. Występujące w rzeczywistych gospodarkach podatki uzależnione od wysokości dochodu, czyli podatki niezryczałtowane, kształtują się z reguły odmiennie w przypadku poszczególnych czynników produkcji, co rzutuje na siłę oddziaływania polityki fiskalnej na ilość kapitału i poziom zatrudnienia. Model McGrattan (1994), uwzględniający występowanie odmiennych stóp podatkowych w przypadku poszczególnych czynników produkcji, stanowi kolejne rozwinięcie modeli realnego cyklu koniunkturalnego. Analiza modelu poprzedzona została przeglądem głównych mechanizmów oddziaływania podatków nakładanych na czynniki produkcji na kształtowanie się ilości kapitału oraz poziom zatrudnienia.

Oddziaływanie niezryczałtowanych podatków na kształtowanie się ilości kapitału odbywa się przede wszystkim poprzez obniżenie krańcowego dochodu z kapitału. Opodatkowanie dochodów z kapitału wiąże się z powstaniem tzw. klina podatkowego, czyli różnicy pomiędzy kosztami kapitału ponoszonymi przez przedsiębiorstwa a dochodami, jakie kapitał przynosi jego właścicielom. Przy wyższych niezryczałtowanych podatkach nakładanych na dochody z kapitału wyższa musi być stopa zwrotu przed opodatkowaniem z dodatkowej inwestycji, by otrzymać określoną wysokość stopy zwrotu po opodatkowaniu ${ }^{46}$. Na kształtowanie się poziomu kapitału negatywny wpływ wywierają również niezryczałtowane podatki obniżające poziom oszczędności. Mechanizmy, poprzez które podatki ${ }^{47}$ mogą prowadzić do obniżenia oszczędności są następujące:

${ }^{46}$ Według raportu OECD (2000) zwiększenie relacji dochodów podatkowych do PKB o 1 pkt proc. powoduje w długim okresie, poprzez negatywny wpływ na inwestycje, zmniejszenie PKB na jednego mieszkańca o 0,3-0,4\% (szerzej nt. wpływu podatków na inwestycje oraz długookresowy wzrost por. np. Krajewski i Mackiewicz, 2007 oraz Wnorowski, 2010).

${ }^{47}$ Zarówno podatki od odsetek, jak i inne podatki oddziałujące pośrednio na poziom oszczędności. 
- zmniejszenie przychodu z oszczędności ${ }^{48}$

- zmniejszenie dochodu do dyspozycji w okresie wysokich dochodów (w wieku produkcyjnym), czyli okresie, w którym generowane są oszczędności ${ }^{49}$;

- relatywne obniżenie, w przypadku podatków progresywnych, dochodów osób zamożniejszych, które cechują się z reguły wyższą krańcową skłonnością do oszczędzania niż osoby mniej zamożne;

- częściowe wyrównanie poziomu dochodów w ciągu życia poprzez przesuniecie części dochodów z okresu pracy na okres emerytury - emerytury finansowane są w znacznym stopniu z podatków (lub wpłat na obowiązkowy system ubezpieczeń społecznych, mających charakter parapodatków);

- zwiększenie zabezpieczenia w przypadku straty dochodu - finansowane z podatków świadczenia społeczne zmniejszają niepewność co do przyszłych dochodów (por. Leibfritz, Thornton, Bibbee, 1997; van den Noord, Heady, 2002).

Negatywny wpływ niezryczałtowanych podatków na oszczędności znajduje potwierdzenie $w$ badaniach empirycznych przeprowadzonych m.in. przez Tanziego i Zee (1998). Zgodnie z otrzymanymi przez nich wynikami, w krajach OECD udział niezryczałtowanych dochodów podatkowych w PKB miał istotny wpływ na stopę oszczędności gospodarstw domowych, a w rezultacie na kształtowanie się poziomu kapitału.

Niezryczałtowane podatki oddziałują również na kształtowanie się zatrudnienia. Opodatkowanie pracy powoduje, że płaca uzyskiwana przez pracownika jest niższa niż koszty pracy ponoszone przez pracodawcę. W wyniku wzrostu niezryczałtowanych podatków nakładanych na płace zwiększeniu ulega różnica między kosztem pracy dla pracodawcy a płacą otrzymywaną przez pracownika, rośnie zatem wysokość klina podatkowego i w rezultacie maleje zatrudnienie. Wpływ klina podatkowego na wysokość zatrudnienia uzależniony jest od elastyczności podaży pracy względem stawki płac i elastyczności popytu na pracę względem stawki płac. Im wyższa jest elastyczność popytu na pracę i podaży pracy względem stawki płac, tym silniejszy negatywny wpływ podatków na wysokość zatrudnienia.

Elastyczność popytu na pracę względem stawki płac wynika z możliwości substytucji pracy kapitałem oraz wpływu wyższych kosztów pracy na opłacalność produkcji. Im silniejszy jest wpływ kosztów pracy na opłacalność produkcji oraz im kapitał jest lepszym substytutem pracy, tym wyższa jest elastyczność popytu

${ }^{48}$ Efekt ten występuje szczególnie silnie w warunkach wysokiej inflacji, ponieważ podstawą opodatkowania jest z reguły dochód nominalny, a nie realny. Przykładowo, w przypadku gdy stopa inflacji jest równa realnej stopie procentowej, rzeczywiste opodatkowanie oszczędności (w ujęciu realnym) jest dwukrotnie wyższe niż nominalna stopa podatkowa.

${ }^{49}$ Zgodnie z teorią cyklu życia, zaproponowaną przez F. Modiglianiego (m.in. w Brumberg, Modigliani, 1954; Ando, Modigliani, 1957), wiek produkcyjny jest okresem uzyskiwania dochodów, wykorzystywanym przez racjonalnych konsumentów do gromadzenia oszczędności, których celem jest przede wszystkim finansowanie konsumpcji w okresie emerytalnym. 
na pracę względem stawki płac. Możliwość substytucji pracy kapitałem oddziałuje na popyt na pracę szczególnie w długim okresie, ponieważ dostosowania ilości kapitału wymagają czasu. Elastyczność popytu na pracę względem stawki płac jest $\mathrm{z}$ reguły wyższa:

- w odniesieniu do pracowników niewykwalifikowanych, ponieważ w tym przypadku zazwyczaj istnieje większa możliwość substytucji kapitału i pracy,

- w gałęziach pracochłonnych, gdyż w gałęziach tych wpływ wzrostu kosztów pracy na opłacalność produkcji jest silniejszy (por. Leibfritz, Thornton, Bibbee, 1997).

W przypadku podaży pracy szczególnie istotne jest rozróżnienie wpływu przejściowej oraz trwałej zmiany stawki płac. Wrażliwość podaży pracy na przejściowe zmiany stawki płac wynika m.in. z międzyokresowej substytucji pracy i czasu wolnego. Natomiast w przypadku trwałych zmian stawki płac efekt ten nie występuje, co wpływa na niższą długookresową wrażliwość podaży pracy względem stawki płac, a co za tym idzie słabsze oddziaływanie trwałych zmian w opodatkowaniu pracy na wysokość zatrudniania. Długookresowa elastyczność podaży pracy względem stawki płac jest szczególnie niska, gdy efekt dochodowy wzrostu płac jest relatywnie silny. W szczególnym przypadku, gdy efekt dochodowy wzrostu płac jest równy efektowi substytucyjnemu (czyli krzywa podaży pracy jest pionowa), podaż pracy jest nieelastyczna względem stawki płac, co oznacza, że wysokość opodatkowania pracy nie wpływa na wysokość zatrudnienia ${ }^{50}$. Elastyczność podaży pracy względem stawki płac, a więc i siła oddziaływania klina podatkowego na zatrudnienie, może być odmienna dla poszczególnych grup podatników. Relatywnie niska elastyczność podaży pracy względem stawki płac występuje, gdy w gospodarstwie domowym pracuje tylko jedna osoba oraz w przypadku podstawowego żywiciela w gospodarstwie domowym, czyli najwięcej zarabiającej osoby w tym gospodarstwie Jedynie w przypadku dodatkowego żywiciela w gospodarstwie domowym wpływ stawki płac na zatrudnienie jest wysoki. Przy wspólnym rozliczaniu się małżonków krańcowa stawka podatkowa pierwszego z małżonków ma przy tym wpływ na decyzję o podjęciu pracy przez drugiego z małżonków (por. van den Noord, Heady, 2002) ${ }^{51}$.

${ }^{50}$ Natomiast w przypadku zakrzywionej do tyłu krzywej podaży pracy, czyli gdy efekt dochodowy wzrostu płac jest silniejszy niż efekt substytucyjny, wzrost opodatkowania pracy powoduje wzrost zatrudnienia. Wpływ podatków na wysokość zatrudnienia w przypadku zakrzywionej do tyłu krzywej podaży pracy omówiony jest m.in. w pracy Stiglitza (1998).

${ }^{51} \mathrm{Na}$ kształtowanie się podaży pracy wpływa nie tylko opodatkowanie pracy, ale także wysokość niezryczałtowanych transferów z budżetu państwa do gospodarstw domowych. Wyższe transfery uzależnione od wysokości dochodu mogą zniechęcać gospodarstwa domowe do podjęcia pracy, ograniczając podaż pracy. Miarą oddziaływania państwa na decyzje dotyczące podjęcia pracy jest stosunek płacy netto do zasiłków otrzymywanych w przypadku zrezygnowania z pracy. Skłonność do podjęcia pracy maleje, gdy na skutek wzrostu roli państwa w gospodarce następuje spadek płacy po opodatkowaniu (na skutek wzrostu podatków) i wzrost transferów, które przyznawane są w przypadku braku zarobków (por. van den Noord, Heady, 2002). 
Elastyczność popytu na pracę względem stawki płac jest z reguły wyższa niż elastyczność podaży pracy względem stawki płac. Dlatego elastyczność rynku pracy wpływa na siłę oddziaływania klina podatkowego na wysokość zatrudnienia. W przypadku elastycznego rynku pracy na skutek wzrostu opodatkowania obniżeniu ulega płaca netto. W rezultacie na skutek wzrostu podatków maleje podaż pracy. W przypadku nieelastycznego rynku pracy nie ulega obniżeniu płaca netto, rosną natomiast koszty pracy. W rezultacie na skutek wzrostu podatków maleje popyt na pracę. Zatem większy negatywny wpływ wzrostu podatków na zatrudnienie występuje przy nieelastycznym rynku pracy (por. Leibfritz, Thornton, Bibbee, 1997).

Większość wyników badań empirycznych potwierdza występowanie zależności między poziomem niezryczałtowanych podatków a wysokością zatrudnienia. Na dodatnią zależność między poziomem opodatkowania pracy a wysokością bezrobocia wskazują m.in. Pissarides (1996), Nickell (1997), Nickell i Layard (1997), Heitger (2000, 2002). Występowanie negatywnego wpływu wyższych podatków na rynek pracy potwierdzają również analizy przeprowadzone w Polsce (por. Bukowski i in., 2005; Krajewski i Mackiewicz, 2006 oraz Góra i in., 2008).

Istnieją zatem empiryczne przesłanki, wskazujące, że opodatkowanie dochodów z kapitału oraz dochodów z pracy wpływa na poziom czynników produkcji. Model przedstawiony przez McGrattan (1994) zakłada, że podatki nakładane na dochody z kapitału i dochody z pracy kształtować się mogą na odmiennym poziomie, co umożliwia wyodrębnienie w modelu oddziaływania każdego $\mathrm{z}$ tych podatków na kształtowanie się poziomu kapitału oraz zatrudnienia.

W przypadku występowania osobnych podatków nakładanych na poszczególne czynniki produkcji ograniczenie budżetowe gospodarstw domowych jest dane wzorem:

$c_{t}+i_{t} \leq\left(1-\tau_{k, t}\right) \rho_{t} k_{t}+\delta \tau_{k, t} k_{t}+\left(1-\tau_{w, t}\right) w_{t} l_{t}+r T_{t}$,

gdzie:

$\tau_{k, t}$-stopa opodatkowania dochodów z kapitału,

$\tau_{w, t}-$ stopa opodatkowania dochodów z pracy,

$\tau_{k, t}, \tau_{w, t} \in(0,1)$.

W modelu przyjmuje się, że poziom użyteczności uzależniony jest od efektywnej konsumpcji oraz tzw. nierozdzielnego czasu wolnego (por. Hansen, Wrigth, 1992), a gospodarstwa domowe maksymalizują sumę zdyskontowanych użyteczności postaci:

$$
U=E\left(\sum_{t=0}^{\infty} \beta^{t} u\left(c_{t}^{e}, \alpha(L) h_{t}\right)\right),
$$


gdzie: $\alpha(L)=\sum_{j=0}^{\infty} \alpha_{j} L^{j}, L-$ operator opóźnień, $\alpha_{j}>0$.

Na kształtowanie się efektywnej konsumpcji $\left(c_{t}^{e}\right)$ oddziałuje zarówno poziom konsumpcji prywatnej, jak i konsumpcji publicznej (por. równanie (13)). Występowanie w funkcji (98) operatora opóźnień oznacza istnienie nierozdzielnego czasu wolnego, czyli wiąże się z założeniem, że na bieżącą użyteczność z czasu wolnego ma wpływ nie tylko bieżący poziom czasu wolnego, ale i jego wcześniejsze wartości (por. Hotz, Kydland, Sedlacek, 1988) ${ }^{52}$.

Przyjmując oznaczenie:

$\tilde{h}_{t}=\alpha(L) h_{t}$

oraz uwzględniając równanie (13) otrzymuje się:

$U=E\left(\sum_{t=0}^{\infty} \beta^{t} u\left(c_{t}+\gamma g_{t}, \tilde{h}_{t}\right)\right)$

McGrattan przyjmuje następującą postać funkcji użyteczności ${ }^{53}$ (por. np. Dejong, Dave, 2007):

$u\left(c_{t}, g_{t}, \tilde{h}_{t}\right)=\frac{\left(\left(c_{t}+\gamma g_{t}\right)^{\chi} \tilde{h}_{t}^{1-\chi}\right)^{1-\sigma_{u}}}{1-\sigma_{u}}$,

gdzie: $\chi \in(0,1), \gamma \in<0,1>, \sigma_{u}>0$.

W modelu, analogicznie jak w pracy Kydlanda i Prescotta (1982), przyjmuje się, że proces inwestycyjny trwa cztery okresy, czyli:

$i_{t}=\varphi_{1} s_{t-3}+\varphi_{2} s_{t-2}+\varphi_{3} s_{t-1}+\varphi_{4} s_{t}$

gdzie:

$s_{t}$ - inwestycje rozpoczęte w okresie $t, \varphi_{j} \geq 0, \sum_{j=1}^{4} \varphi_{j}=1$.

${ }^{52}$ Założenie o nierozdzielności czasu wolnego można zinterpretować następująco: na to, ile obecnie dana osoba potrzebuje czasu wolnego ma wpływ to, w jakim stopniu dysponowała ona w przeszłości czasem wolnym, umożliwiającym wykonanie okresowych napraw czy też regenerację sił (por. Hansen, Wrigth, 1992).

${ }^{53}$ Inną często stosowaną wersją funkcji użyteczności o stałej międzyokresowej elastyczności substytucji konsumpcji jest funkcji użyteczności, w której konsumpcja i czas pracy występują addytywnie, tj. w przypadku braku występowania polityki fiskalnej i niewystępowania nierozdzielnego czasu wolnego funkcja postaci: $u_{t}\left(c_{t}, l_{t}\right)=\frac{c_{t}{ }^{1-\sigma_{c}}}{1-\sigma_{c}}-\frac{l_{t}{ }^{1-\sigma_{l}}}{1-\sigma_{l}}$ (Koloch, 2008; rozszerzenia tej funkcji por. np. Levine, Pearlman, Yang, 2007; Kolasa, 2008). 
Zatem w powyższym równaniu $\varphi_{j}$ oznacza udział nakładów inwestycyjnych $\mathrm{z}$ okresu $t$ użytych w procesach inwestycyjnych $j$ okresów przed ukończeniem.

Kapitał w kolejnym okresie określony jest zatem wzorem:

$k_{t+1}=(1-\delta) k_{t}+s_{t-3}$.

W każdym okresie przedsiębiorstwa wybierają poziom produkcji, kapitału i pracy, który maksymalizuje zysk $f\left(z_{t}, k_{t}, l_{t}\right)-\rho_{t} k_{t}-w_{t} l_{t}$, gdzie $f$ jest funkcją produkcji Cobba-Douglasa o stałych efektach skali, natomiast $z_{t}$ oznacza zmienną stochastyczną obrazującą szoki dotyczące poziomu technologii.

McGrattan zakłada, że dochody budżetowe pochodzą z podatków nakładanych na czynniki produkcji i w każdym okresie budżet jest zrównoważony. Różnica pomiędzy dochodami z podatków a wydatkami rządowymi jest przeznaczana na transfery dla gospodarstw domowych, czyli:

$r T_{t}=\tau_{k, t}\left(\rho_{t}-\delta\right) k_{t}+\tau_{w, t} w_{t} l_{t}-g_{t}$.

W modelu występują następujące zmienne stochastyczne:

- poziom technologii,

- wydatki rządowe,

- stopa opodatkowania kapitału,

- stopa opodatkowania pracy.

Zmienne stochastyczne są określone równaniem postaci:

$v_{t+1}=a(L) v_{t}+b X_{t}+\xi_{t+1}$,

gdzie:

$v_{t}=\left[z_{t}, g_{t}, \tau_{k, t}, \tau_{w, t}\right]^{T}$,

$L$ - operator opóźnien,

$X_{t}=\left[1, k_{t}, s_{t-1}, s_{t-2}, s_{t-3}, i_{t}, l_{t}\right]^{T}$,

$\xi_{t}$ - wektor niezależnych składników losowych o rozkładzie normalnym.

McGrattan szacuje parametry modelu na podstawie metody największej wiarygodności opierając się na danych dla gospodarki amerykańskiej. Następnie w ramach modelu analizowane są skutki szoków fiskalnych dotyczących poziomu opodatkowania poszczególnych czynników produkcji.

Szok fiskalny polegający na wzroście opodatkowania wynagrodzeń sprawia, że maleje krańcowy produkt z pracy po opodatkowaniu, co przekłada się na obniżenie się poziomu zatrudnienia. Ograniczeniu ulega również ilość kapitału, ponieważ z jednej strony przy niższym poziomie zatrudnienia maleje krańcowy produkt kapitału, a z drugiej strony kapitał zamieniany jest na konsumpcję w celu zminimalizowania wahań konsumpcji. Analogicznie, wzrost opodatkowania dochodów z kapitału oddziałuje nie tylko na obniżenie się krańcowego produktu 
kapitału po opodatkowaniu, ale też w pewnym stopniu, w wyniku zmniejszenia się ilości kapitału, na kształtowanie się krańcowego produktu pracy. W rezultacie zmiany opodatkowania kapitału oddziałują również na kształtowanie się zatrudnienia.

Opierając się na wykonanych symulacjach McGrattan otrzymała, że istotna część wariancji produkcji (ok. 30\%) jest spowodowana szokami fiskalnymi: stochastycznymi zmianami wydatków rządowych, podatków nakładanych na dochody z kapitału oraz podatków nakładanych na wynagrodzenia. Z przeprowadzonych przez autorkę symulacji wynika, że spośród szoków fiskalnych na kształtowanie się fluktuacji produkcji w największym stopniu oddziałują zmiany opodatkowania kapitału. Zmiany opodatkowania poszczególnych czynników produkcji oddziałują także na pozostałe zmienne makroekonomiczne (konsumpcję, podaż pracy, kapitał i inwestycje), przy czym w ramach analizowanego modelu w przypadku wszystkich zmiennych poza podażą pracy wpływ zmian podatku nakładanego na kapitał okazał się silniejszy niż wpływ zmian opodatkowania pracy. Z drugiej strony z symulacji otrzymanych na podstawie modelu Ardagny (2001) wynika, że zmiany opodatkowania kapitału wywierają mniejszy wpływ na kształtowanie się fluktuacji PKB niż zmiany podatków nakładanych na wynagrodzenia (por. też Hemming, Kell, Mahfouz, 2002). Jak wskazują przytoczone wyniki badań, siła podażowego odziaływania szoków podatkowych na fluktuacje PKB może być odmienna dla różnych rodzajów podatków ${ }^{54}$. Jednocześnie $\mathrm{z}$ badań nie wynika jednoznacznie, jaki rodzaj opodatkowania w największym stopniu objaśnia podażowe wahania PKB, a uzyskane rezultaty uzależnione mogą być m.in. od specyfikacji modelu oraz wartości parametrów uzyskanych dla danego kraju i okresu objętego badaniem.

\section{Podsumowanie}

W rozdziale omówione zostały podażowe mechanizmy oddziaływania polityki fiskalnej na fluktuacje gospodarcze. Teoretyczną analizę efektów podażowych przedstawiono opierając się na modelach realnego cyklu koniunkturalnego, zaliczanych do grupy dynamicznych, stochastycznych modeli równowagi ogólnej. W modelach RBC zakłada się, że płace i ceny są doskonale elastyczne i natychmiast dostosowują się do poziomu równoważącego rynek, a wahania gospodarcze nie wynikają z odchyleń produkcji od poziomu potencjalnego, lecz z decyzji optymalizacyjnych gospodarstw domowych. W rezultacie na sferę realną oddziałuje jedynie podażowa strona gospodarki, co umożliwia wyodrębnienie podażowych efektów zmian w wydatkach rządowych i podatkach.

\footnotetext{
${ }^{54}$ Porównanie skutków opodatkowania dochodów z poszczególnych czynników produkcji ukazują też Dotsey (1994), Ohanian (1997), Romer i Romer (2007) oraz Ferroni (2010).
} 
Jak wynika m.in. z analiz Aschauera (1988) oraz Amblera, Bouakeza i Cardii (2010), podażowe odziaływanie wydatków rządowych na produkcję uzależnione jest od kształtowania się krańcowej stopy substytucji pomiędzy konsumpcją prywatną a konsumpcją dóbr publicznych oraz krańcowego produktu dóbr dostarczanych przez państwo. Jeżeli konsumpcja dóbr publicznych nie jest substytutem dóbr prywatnych, a dobra publiczne nie stanowią czynnika ułatwiającego produkcję dóbr prywatnych, wówczas wydatki rządowe stanowią drenaż zasobów z gospodarki i powodują proporcjonalne zmniejszenie majątku gospodarstw domowych. W tym przypadku wzrost wydatków rządowych powoduje negatywny efekt majątkowy. Następuje ograniczenie konsumpcji i czasu wolnego oraz wzrost podaży pracy. Jednocześnie rośnie zatrudnienie i produkcja, a zmniejszeniu ulega konsumpcja i stawka płac. Kierunek podażowego oddziaływania wzrostu wydatków rządowych na konsumpcję i stawkę płac jest więc odmienny niż w tradycyjnym popytowym podejściu keynesistowskim. Warto jednocześnie zaznaczyć, że przy całkowitej substytucji pomiędzy konsumpcją prywatną a konsumpcją dóbr publicznych lub wysokiej produktywności dóbr publicznych wydatki rządowe nie wpływają na poziom majątku i decyzje gospodarstw domowych.

W przypadku przejściowego wzrostu wydatków rządowych dochodzi do międzyokresowej substytucji czasu wolnego. Zmiany przejściowe wywierają jednak, co ukazują Baxter i King (1993), słabszy wpływ na produkcję niż trwałe podwyższenie wydatków rządowych.

Wprowadzenie do modeli realnego cyklu koniunkturalnego szoków wynikających ze stochastycznych zmian w wydatkach rządowych wpływa na lepsze odwzorowanie przez nie zależności makroekonomicznych. Jak wskazują m.in. Christiano i Eichenbaum (1992) oraz Rebelo (2005) uwzględnienie w modelach RBC wydatków rządowych obniża korelację pomiędzy ilością przepracowanych godzin a wydajnością pracy, przybliżając oszacowaną korelację do wielkości występujących w rzeczywistych gospodarkach.

Opisane powyżej pozytywne oddziaływanie wzrostu wydatków rządowych na kształtowanie się produkcji otrzymuje się przy założeniu finansowania wydatków rządowych transferami lub zryczałtowanymi podatkami, czyli podatkami niezależnymi od dochodu. Z modeli realnego cyklu koniunkturalnego wynika, że rozkład w czasie transferów lub zryczałtowanych podatków nie wpływa na kształtowanie się produkcji oraz pozostałych zmiennych realnych, czyli występuje postulowana przez Barro (1974) ekwiwalencja ricardiańska pomiędzy długiem publicznym a finansowaniem wydatków budżetowych ze zryczałtowanych podatków. Obniżka podatków, której towarzyszy wzrost deficytu budżetowego, nie prowadzi do wzrostu konsumpcji, ponieważ gospodarstwa domowe, oczekując w przyszłości wyższych podatków koniecznych dla spłacenia zaciągniętego długu, zwiększają na ich poczet oszczędności. Występowanie ekwiwalencji ricardiańskiej, choć wynika z założeń teoretycznych, jest często kwestionowane ze względu m.in. na skończony horyzont planowania, niepewność co do przyszłego 
rozkładu obciążeń podatkowych czy występowanie ograniczeń na rynku kapitałowym.

Uzależnione do wielkości dochodu podatki niezryczałtowane, w odróżnieniu od podatków zryczałtowanych, oddziałują na kształtowanie się produkcji. Podwyższenie stopy podatkowej prowadzi do obniżenia się produkcji i konsumpcji. Wzrost opodatkowania zmniejsza krańcowy produkt z kapitału po opodatkowaniu i sprawia, że ilość kapitału ulega obniżeniu. Natomiast teoretyczne implikacje wpływu stóp podatkowych na kształtowanie się zatrudnienia nie są jednoznaczne. Efekt substytucyjny powoduje bowiem obniżenie zatrudnienia na rzecz czasu wolnego, a jednocześnie efekt dochodowy związany z obniżeniem się kapitału i majątku gospodarstw domowych przekłada się na ograniczenie czasu wolnego i zwiększenie zatrudnienia. Wyniki badań empirycznych wskazują jednak, że wzrost opodatkowania negatywnie oddziałuje nie tylko na ilość kapitału, ale i na poziom zatrudnienia. Ponadto, jak wynika m.in. z badań przeprowadzonych przez McGrattan (1993) oraz Ferroniego (2010), siła podażowych efektów zmian stóp podatkowych może być odmienna w zależności od tego, czy analizowane szoki dotyczą podatków nakładanych na dochody z pracy, czy też na dochody z kapitału. Wpływ niezryczałtowanych podatków na decyzje gospodarstw domowych i przedsiębiorstw powoduje, że oddziaływanie wzrostu wydatków rządowych finansowanych niezryczałtowanymi podatkami na gospodarkę może być zupełnie odmienne niż w przypadku ich finasowania podatkami zryczałtowanymi, co pokazują m.in. symulacje Baxter i Kinga (1993). Wynika z nich, że choć zwiększenie wydatków rządowych prowadzi do wzrostu produkcji, jeśli w celu zrównoważenia budżetu następują dostosowania w poziomie podatków zryczałtowanych, to już w przypadku finasowania wyższych wydatków podatkami niezryczałtowanymi następuje znaczny spadek produkcji. Na podstawie podażowych modeli realnego cyklu koniunkturalnego otrzymuje się zatem, że sposób finansowania wydatków rządowych ma kluczowe znaczenie dla kierunku oddziaływania polityki fiskalnej na fluktuacje gospodarcze. 


\section{Popytowe efekty polityki fiskalnej na gruncie nowej ekonomii keynesistowskiej}

\section{Wprowadzenie}

Zgodnie z podejściem zapoczątkowanym przez Keynesa, zainspirowanego doświadczeniami Wielkiego Kryzysu, polityka fiskalna wpływa na gospodarkę przede wszystkim poprzez oddziaływanie na poziom agregatowego popytu. Analiza popytowych skutków zmian wydatków rządowych i podatków jest szczególnie istotna również obecnie, ponieważ począwszy od pojawienia się kryzysu finansowego na świecie nastąpiło znaczne zwiększenie znaczenia polityki fiskalnej jako narzędzia stymulowania popytu (por. np. Auerbach, 2009). Z tego względu w niniejszym rozdziale teoretycznej analizie poddane zostały efekty polityki fiskalnej w warunkach występowania sztywności nominalnych.

Jak powszechnie wiadomo, zgodnie z szeroko rozpowszechnioną interpretacją popytowego oddziaływania polityki fiskalnej na gospodarkę przedstawioną w podręczniku Samuelsona z 1948 roku (wydanie polskie - Samuelson, Nordhaus, 1995), wraz ze wzrostem wydatków rządowych następuje mnożnikowy wzrost agregatowego popytu i w efekcie również produkcji. Podobny, choć słabszy mechanizm, występuje w przypadku obniżenia poziomu podatków. Jednocześnie w modelu przedstawionym przez Samuelsona całkowicie pomijane są podażowe efekty wynikające z prowadzenia ekspansywnej polityki fiskalnej, a siła popytowego oddziaływania polityki fiskalnej na gospodarkę zależy przede wszystkim od wysokości krańcowej skłonności do konsumpcji ${ }^{1}$. W wyniku rozszerzenia modelu Samuelsona o rynek pieniężny powstał słynny model IS-LM Hicksa (1937) i Hansena (1953)². Uwzględnienie rynku pieniężnego osłabia oddziaływanie wydatków rządowych i podatków na produkcję, co wynika z wpływu wyższej produkcji na popyt na pieniądz, a w efekcie na wzrost stopy procento-

\footnotetext{
${ }^{1}$ Poziom krańcowej skłonności do konsumpcji zależy przy tym diametralnie od tego, czy analizowana jest trwała, czy też przejściowa zmiana dochodu (Ando i Modigliani, 1963). Ponadto krańcowa skłonność do konsumpcji nie musi być stała dla różnych poziomów produkcji. Jak zauważył już w 1936 r. Keynes krańcowa skłonność do konsumpcji wykazuje tendencję do obniżania się wraz ze wzrostem dochodów. Wynika to z faktu, że wraz ze wzrostem dochodu maleje udział konsumpcji w dochodzie (Keynes, 1936).

${ }^{2}$ Model Samuelsona oraz model IS-LM są szczegółowo opisane z perspektywy polityki fiskalnej m.in. przez Rzońcę (2007).
} 
wej i wypychanie części inwestycji. Jednak zgodnie z ortodoksyjnym podejściem keynesowskim popyt na pieniądz silnie reaguje na zmiany stopy procentowej, a jednocześnie inwestycje nie są silnie uzależnione od wysokości oprocentowania, czyli zmiany w wydatkach rządowych nadal silnie oddziałują na kształtowanie się agregatowego popytu ${ }^{3}$. Ortodoksyjne stanowisko keynesowskie odnoszące się do nachylenia krzywych IS i LM miało początkowo poparcie empiryczne (por. np. Klein, 1968), a popytowy model IS-LM miał dominujące znaczenie w myśleniu ekonomicznym w latach 50. i 60. XX w. (por. Snowdon, Vane, Wynarczyk, 1998).

Przedstawiony przez Samuelsona oraz Hicksa i Hansena popytowy mechanizm oddziaływania polityki fiskalnej opiera się na założeniu występowania sztywności nominalnych w gospodarce. Od lat 70 . XX w. coraz bardziej poddawane były pod wątpliwość założenia dotyczące sztywności nominalnych cen i płac. Wskazywano m.in. na brak przekonujących mikroekonomicznych przyczyn ich występowania (por. np. Blaug 1994; Snowdon, Vane, Wynarczyk, 1998)4. Po okresie zmasowanej krytyki w latach 90. XX w. nastąpił jednak renesans zainteresowania keynesizmem (por. Wojtyna, 2000). W tym w szczególności w ramach nowej ekonomii keynesistowskiej (New Keynesian) podjęto próbę wprowadzenia sztywności cen i płac do stochastycznych, dynamicznych modeli równowagi ogólnej.

Obecnie modele nowej ekonomii keynesistowskiej stanową jedno z podstawowych narzędzi badania skutków polityki gospodarczej. $Z$ tego względu w niniejszej pracy na ich podstawie przeprowadzono teoretyczną analizę oddziaływania polityki fiskalnej na wahania koniunktury w warunkach występowania sztywności nominalnych. Z jednej strony modele nowej ekonomii keynesistowskiej uwzględniają efekty popytowe. $Z$ drugiej strony modele te wykorzystują metodologię dynamicznych, stochastycznych modeli równowagi ogólnej, czyli w odróżnieniu od starszych modeli popytowych, takich jak np. model IS-LM, umożliwiają oparcie analizy na decyzjach optymalizacyjnych gospodarstw domowych i przedsiębiorstw.

W pierwszej części rozdziału przedstawione zostały główne założenia nowej ekonomii keynesistowskiej. Następnie poddano analizie efekty polityki fiskalnej w warunkach sztywności nominalnych cen oraz sztywności nominalnych płac. W dalszych podrozdziałach ukazano popytowe oddziaływanie polityki fiskalnej w sytuacji występowania przyzwyczajeń konsumpcyjnych oraz gospodarstw niericardiańskich.

\footnotetext{
${ }^{3}$ Uwzględniając ponadto efekty majątkowe wzrostu wydatków rządowych finansowanych emisją obligacji, otrzymuje się, że popytowe oddziaływanie polityki fiskalnej może być nawet silniejsze, niż wynika to ze standardowego modelu IS-LM (por. Blinder, Solow, 1975). Warto jednak zaznaczyć, że aby występowały efekty majątkowe emisji obligacji, muszą one stanowią majątek netto gospodarstw domowych, czyli nie może zachodzić ekwiwalencja ricardiańska opisana przez Barro (1974).

${ }^{4}$ Szerzej na głównych zarzutów wysuwanych wobec keynesizmu w latach 70. i 80. XX w. por. Wojtyna (2000).
} 


\subsection{Ogólna charakterystyka modeli nowej ekonomii keynesistowskiej}

Modele nowej ekonomii keynesistowskiej, określane również jako modele nowej syntezy neoklasycznej (New Neoclassical Synthesis) ${ }^{5}$, opierają się na podstawach mikroekonomicznych dotyczących zachowania się gospodarstw domowych i przedsiębiorstw, jednak w odróżnieniu od modeli realnego cyklu koniunkturalnego uwzględniają występowanie sztywności nominalnych $\mathrm{w}$ gospodarce (por. Wojtyna, 2000). Nowa ekonomia keynesistowska stanowi zatem oparcie podejścia keynesistowskiego na mikropodstawach. W podejściu tym zakłada się $\mathrm{z}$ reguły, że gospodarstwa domowe i przedsiębiorstwa opierają się na racjonalnych oczekiwaniach i na międzyokresowej optymalizacji (por. Bludnik, 2010). Jednocześnie jednak odchodzi się od założenia dotyczącego natychmiastowego dostosowywania się płac i cen, przyjmując występowanie konkurencji monopolistycznej i stopniowej indeksacji cen. W rezultacie rzeczywista produkcja może odbiegać od poziomu potencjalnego ${ }^{6}$. Ponadto polityka monetarna przestaje być neutralna w krótkim okresie (por. Gali, 2008).

Pierwsze prace uwzględniające podejście nowej ekonomii keynesistowskiej zawarte zostały w pracy Mankiwa i Romera (1991). W latach 90. XX w. modele nowokeynesistowskie ${ }^{7}$ stały się standardowym narzędziem służącym do analizy skutków polityki monetarnej (por. Clarida, Gali, Gertler, 1999; Baranowski, 2011). Równocześnie pojawiły się nowokeynesistowskie dynamiczne, stochastyczne modele równowagi ogólnej uwzględniające wpływ polityki fiskalnej. W modelach nowej ekonomii keynesistowskiej występuje zarówno efekt podażowy wzrostu wydatków rządowych, wynikający z negatywnego efektu majątkowego, jak i efekt popytowy, wynikający ze sztywności nominalnych w gospodarce.

Modele nowokeynesistowskie, podobnie jak modele RBC, oceniane są głównie na podstawie tego, czy zmienne symulowane wygenerowane na ich podstawie są w stanie odzwierciedlać relacje pomiędzy rzeczywistymi zmiennymi makroekonomicznych (por. np. Smets, Wouters 2003, 2004; Adolfson, Laseen, Linde, Villani, 2008; Kuchta, 2012).

${ }^{5}$ Określenie nowa synteza neoklasyczna wprowadzili Goodfriend i King (1997). Inne określenia nowej ekonomii keynesistowskiej to: model neowicksellowski (Woodford, 2003), nowy konsens w makroekonomii (Arestis 2009), model neokeynesowski (Blanchard, 2009).

${ }^{6} \mathrm{~W}$ modelach nowej ekonomii keynesistowskiej produkcja potencjalna odpowiada produkcji wynikającej ze standardowego modelu RBC (por. Bludnik, 2010). Występujące wahania produkcji mogą być zatem również następstwem zmian produkcji potencjalnej, tj. optymalnej reakcji gospodarki na zakłócenia realne (por. Mankiw, 2006; Gali, 2009).

${ }^{7} \mathrm{~W}$ pracy dla zachowania spójności z określeniem „nowa ekonomia keynesistowska” stosowany jest zwrot „model nowokeynesistowski”. Tłumaczenie takie stosują m.in. Baranowski i Szafrański (2011). Alternatywne thumaczenie - „model nowokeynesowski” znajduje się m.in. w pracach Bludnik (2010) oraz Grabka, Kłosa i Kolocha (2010). 
Podstawowy model nowej ekonomii keynesistowskiej określony jest przez trzy równania (por. np. Gali, 2008; Bludnik, 2010; Baranowski, 2011):

- funkcję zagregowanego popytu,

- nowokeynesistowską krzywą Phillipsa,

- regułę Taylora.

Funkcja zagregowanego popytu, stanowiąca dynamiczną wersję krzywej IS (por. Baranowski, 2011), określa następujące równanie:

$\tilde{y}_{t}=E_{t}\left(\tilde{y}_{t+1}\right)+\frac{1}{\sigma_{C}}\left[r_{t}^{n}-E_{t}\left(\pi_{t+1}\right)-r_{t}^{*}\right]+\xi_{y, t}$,

gdzie:

$\tilde{y}_{t}-$ luka produktowa ${ }^{8}$,

$r_{t}^{n}$ - nominalna stopa procentowa,

$r_{t}^{*}$ - naturalna stopa procentowa,

$\pi_{t}-$ inflacja,

$\sigma_{C}>0$.

Wysokość popytu uzależniona jest od decyzji optymalizacyjnych gospodarstw domowych. Naturalna stopa procentowa $r_{t}^{*}$ intepretowana jest jako stopa procentowa występującą w przypadku braku sztywności nominalnych, natomiast luka produktowa jako odchylenie produkcji od poziomu wynikającego z podażowego modelu RBC (por. Blanchard, 2009).

Nowokeynesistowską krzywa Phillipsa określa równanie postaci:

$\pi_{t}=\beta_{\pi} E_{t}\left(\pi_{t+1}\right)+\kappa_{y} \tilde{y}_{t}+\xi_{\pi, t}$,

gdzie $\beta_{\pi}, \kappa_{y}>0$.

Równanie (107) stanowi funkcję zagregowanej podaży. Podaż wyznaczana jest na podstawie decyzji cenowych przedsiębiorstw działających na rynku, który w modelach nowokeynesistowskich, odmiennie niż w modelach RBC, nie jest rynkiem doskonale konkurencyjnym. Ponadto decyzje cenowe firm nie są podejmowane jednocześnie. $W$ danym okresie jedynie część przedsiębiorstw rewiduje swoje decyzje na podstawie decyzji płynących z rynku (por. Calvo, 1983). W przypadku pozostałych podmiotów, które nie dostosowują w danym okresie cen, zmiany zagregowanego popytu oddziałują więc na kształtowanie się produkcji. W rezultacie istnienie sztywności nominalnych cen przekłada się na występowanie wahań produkcji wokół poziomu potencjalnego (por. Gali, Getler, 2007; Bludnik, 2010).

Podstawowa wersja reguły pieniężnej, stanowiąca regułę typu Taylora (1993), w modelach nowokeynesistowskich przyjmuje postać:

${ }^{8} \mathrm{Na}$ określenie różnicy pomiędzy produkcją rzeczywistą a potencjalną stosuje się również określenie luka popytowa, luka produkcyjna lub komponent cykliczny PKB.

${ }^{9}$ Przedstawione równanie stanowi podstawową wersję reguły Taylora. Opis rozszerzeń reguły Taylora omówiony jest m.in. w pracy Baranowskiego (2008). 
$r_{t}^{n}=r_{t}^{*}+r_{Y} \tilde{y}_{t}+r_{\pi}\left(\pi_{t}-\pi^{*}\right)+\xi_{r, t}$,

gdzie:

$\pi^{*}$ - docelowy poziom inflacji,

$r_{Y}, r_{\pi}>0$.

Zatem bank centralny podnosi poziom stóp procentowych w sytuacji, gdy inflacja kształtuje się powyżej poziomu docelowego lub rzeczywista produkcja przewyższa poziom potencjalny. W modelach nowokeynesistowskich zakłada się występowanie sztywności nominalnych cen, tak więc bank centralny, poprzez zmiany nominalnych stóp procentowych, oddziałuje na poziom realnej stopy procentowej oraz kształtowanie się PKB w krótkim okresie. Bank centralny oddziałuje ponadto na zachowanie gospodarstw domowych poprzez kanał oczekiwań. Gospodarstwa określając wartość oczekiwaną przyszłej luki produktowej i inflacji, uwzględniają bowiem nie tylko przyszłe zachowania podmiotów prywatnych, ale także określoną przez regułę Taylora politykę banku centralnego (por. Bludnik, 2010).

Ważny element modeli nowej ekonomii keynesistowskiej stanowi założenie dotyczące występowania konkurencji monopolistycznej (por. Wojtyna, 2000). Z reguły przyjmuje się jedno z poniższych założeń (por. np. Linnemann i Schabert, 2003):

- przedsiębiorcy, działając w warunkach konkurencji monopolistycznej, wytwarzają dobra pośrednie i sprzedają je firmom działającym w warunkach konkurencji doskonałej, które przetwarzają dobra pośrednie na dobra finalne zgodnie z funkcją produkcji cechującą się stałą elastycznością substytucji, czyli funkcją CES (Constant Elasticity of Substitution),

- przedsiębiorstwa sprzedają gospodarstwom domowych koszyk różnorodnych dóbr finalnych, natomiast gospodarstwa domowe agregują koszyk dóbr cechujących się stałą elastycznością substytucji.

Jeśli zakłada się, że rynek dóbr pośrednich jest rynkiem konkurencji monopolistycznej, wówczas z reguły przyjmuje się, że dobra pośrednie są przetwarzane na dobra finalne zgodnie z funkcją postaci:

$Y_{t}=\left(\int_{0}^{1} y_{t}(i)^{\frac{\eta-1}{\eta}} d i\right)^{\frac{\eta}{\eta-1}}$,

gdzie:

$Y_{t}$ - produkcja dobra finalnego ${ }^{10}$,

$y_{t}(i)$ - produkcja $i$-tego dobra pośredniego,

${ }^{10} \mathrm{~W}$ pracy przyjęto notację, zgodnie z którą jeśli w modelu występują zarówno dobra pośrednie, jak i dobra finalne, wówczas wielkości odnoszące się do dóbr finalnych są oznaczone wielką literą, natomiast wielkości dotyczące dóbr pośrednich - małą literą z subskryptem $i$. 
$\eta$ - elastyczność substytucji dóbr pośrednich wykorzystywanych do produkcji dobra finalnego,

$\eta>1$.

Popyt na każde z dóbr pośrednich jest określony wzorem:

$y_{t}(i)=P_{t}\left(\frac{p_{t}(i)}{P_{t}}\right)^{-\eta}$,

gdzie:

$p_{t}(i)$ - cena $i$-tego dobra pośredniego,

$P_{t}$ - cena dobra finalnego.

Natomiast cena dobra finalnego jest określona równaniem:

$P_{t}=\left[\int_{0}^{1} p_{t}(i)^{1-\eta} d i\right]^{\frac{1}{1-\eta}}$.

Alternatywnie założyć można, że gospodarstwa domowe konsumują różnorodne dobra dostarczane przez przedsiębiorstwa działające w warunkach konkurencji monopolistycznej, a następnie agregują je zgodnie z indeksem Dixit i Stiglitza (1977):

$C_{t}=\left[\int_{0}^{1} c_{i, t}^{\frac{\eta_{c}-1}{\eta_{c}}} d i\right]^{\frac{\eta_{c}}{\eta_{c}-1}}$,

gdzie:

$c_{i, t}-$ dobro $i$ w koszyku dóbr,

$\eta_{c}$ - elastyczność substytucji dóbr konsumpcyjnych składających się na koszyk dóbr konsumowany przez gospodarstwo domowe,

$$
\eta_{c}>1 \text {. }
$$

Na poziom użyteczności gospodarstw domowych wpływa nie wysokość konsumpcji poszczególnych dóbr, lecz jedynie wielkość indeksu $C_{t}$. Analogiczny indeks wyznaczyć można dla poziomu cen:

$P_{t}=\left[\int_{0}^{1} p_{i, t}{ }^{1-\eta_{c}} d i\right]^{\frac{1}{1-\eta_{c}}}$,

gdzie:

$p_{i, t}$ - cena dobra $i$ w koszyku konsumowanych dóbr.

Wysokość popytu na poszczególne dobra $c_{i, t}$ określona jest w tym przypadku wzorem: 
$c_{i, t}=C_{t}\left(\frac{p_{i, t}}{P_{t}}\right)^{-\eta_{c}}$.

Z punktu widzenia gospodarstw domowych istotna jest jedynie wielkość indeksów $C_{t}$ oraz $P_{t}$ (por. Woodford, 2003). Poziom użyteczności jest uzależniony od indeksu $C_{t}$, natomiast wydatki gospodarstw domowych wynoszą $C_{t} P_{t}$.

Jak widać, dla obydwu przedstawionych założeń dotyczących konkurencji monopolistycznej otrzymuje się analogiczne wyniki, przy czym odmienna jest ich interpretacja ${ }^{11}$.

Pierwsze modele nowej ekonomii keynesistowskiej zazwyczaj opierały się na wielu upraszczających założeniach, takich jak:

- dostęp do doskonałej informacji,

- brak niezależnej funkcji inwestycji,

- występowanie homogenicznych podmiotów,

- występowanie doskonałego rynku finansowego,

- brak rynku pracy ${ }^{12}$.

Współczesne modele nowokeynesistowskie często odchodzą od tych założeń. Skutki wprowadzenia reguł heurystycznych w miejsce doskonałej informacji ukazuje m.in. DeGrauwe (2008). Do głównych modeli zawierających funkcję inwestycji zaliczyć można modele Christiano, Eichenbauma i Evansa (2005) oraz Smetsa i Woutersa $(2003,2007)^{13}$. Skutki przyjęcia założenia o heterogeniczności podmiotów przedstawiają Ghironi i Melitz (2005) oraz Branch i McGough (2009). Założenie dotyczące występowania niedoskonałego rynku finansowego wprowadzili m.in. Bernanke, Gertler i Gilchrist (1999) oraz Meier i Muller (2006). Zagadnienia związane z bezrobociem do modeli nowej ekonomii keynesistowskiej analizują natomiast Mortensen i Pissarides (1999) oraz Danthine i Kurmann (2004).

Rozwinięcia modeli nowej ekonomii keynesistowskiej obejmują również analizę wydatków rządowych i podatków. Implikacje uwzględnienia polityki fiskalnej w modelach nowej ekonomii keynesistowskiej zostały przedstawione w dalszej części rozdziału. W pierwszej kolejności zaprezentowano skutki polityki

${ }^{11} \mathrm{~W}$ pracy w większości przypadków przyjęto, że konkurencja monopolistyczna występuje na rynku dóbr pośrednich. Jedynie w ramach analizy przyzwyczajeń konsumpcyjnych zawartej w dalszej części rozdziału założono, że gospodarstwa domowe konsumują różnorodne dobra dostarczane przez przedsiębiorstwa działające $\mathrm{w}$ warunkach konkurencji monopolistycznej na rynku dóbr finalnych. Przyjęcie takiego założenia w ramach analizy przyzwyczajeń konsumpcyjnych umożliwia bowiem bardziej intuicyjną interpretację wyników.

${ }^{12}$ Szerzej na temat znaczenia przedstawionych założeń w modelach nowej ekonomii keynesistowskiej por. Bludnik (2010).

${ }^{13}$ Zatem w modelach nowej ekonomii keynesistowskiej zawierających funkcję inwestycji, podobnie jak w modelach RBC, akumulacja kapitału jest objaśniana w ramach modelu (por. Gali, 2008). 
fiskalnej w warunkach występowania sztywności nominalnych cen oraz płac. Następnie zbadano wpływ uchylenia niektórych założeń podstawowego modelu nowokeynesistowskiego, tj. zaprezentowano efekty zmian wydatków rządowych i podatków przy występowaniu przyzwyczajeń konsumpcyjnych oraz w sytuacji, gdy część gospodarstw nie posiada dostępu do rynku kredytowego.

\subsection{Polityka fiskalna przy występowaniu sztywności nominalnych cen}

Modele dotyczące sztywności nominalnych na rynku produktów są często traktowane jako najistotniejszy element programu badawczego nowej ekonomii keynesistowskiej (por. Wojtyna, 2000). Sztywności nominalne cen objaśnia się głównie na podstawie modeli kosztów menu, w których kładzie się nacisk zarówno na koszty transakcyjne (Mankiw, 1985), jak i występowanie tzw. niemal racjonalności (Akerlof, Yellen, 1985) ${ }^{14}$. Założenie dotyczące występowania sztywności nominalnych cen ma przy tym poparcie w licznych badaniach na poziomie mikroekonomicznym (por. np. Cecchetti, 1986; Kashyap, 1995; Levy i in., 1997; Taylor, 1999; Bils, Klenow, 2004; Dhyne i in., 2006).

Skutki wprowadzenia polityki fiskalnej do modelu nowej ekonomii keynesistowskiej przy występowaniu sztywności nominalnych cen ukazuje praca Woodforda (1996) (por. Gali, 2008). Bardziej współczesne rozwinięcie analizy polityki fiskalnej w warunkach stopniowego dostosowywanie się cen stanowi model przedstawiony przez Linnemanna i Schaberta (2003).

Linnemann i Schabert zakładają, że przedsiębiorstwa, wytwarzające dobra pośrednie w warunkach konkurencji monopolistycznej, dostosowują ceny zgodnie ze schematem Calvo (1983). Dostosowania cenowe typu Calvo oznaczają, że istnieje określone, stałe prawdopodobieństwo, że przedsiębiorstwo w danym okresie zmieni cenę (por. np. Erceg, Henderson i Levin, 2000; Kollmann, 2001; McCandless, 2008). W rezultacie ustalony odsetek firm nie zmienia cen w danym okresie, niezależnie od tego, w jakim stopniu ustalona wcześniej cena odbiega od ceny opróżniającej rynek ${ }^{15}$. Otrzymuje się zatem:

${ }^{14}$ Koncepcja niemal racjonalności wiąże się z występowaniem sytuacji, w której wzrost zysku na skutek zmiany ceny z poziomu obecnego do poziomu optymalnego byłby niewielki, co sprawia, że przedsiębiorstwo nie ma wystarczających bodźców do dostosowania ceny (szerzej na ten temat por. Wojtyna, 2000).

${ }^{15}$ Do innych metod wprowadzenia do modelu sztywności nominalnych cen zaliczyć można schemat ustalania cen, w którym okres utrzymywania się ceny na niezmienionym poziomie jest określony deterministycznie (por. Taylor, 1980; Chari, Kehoe, McGrattan, 2000), czy też schemat, którym okres pojawienie się dostosowania cenowego jest uzależniony od sytuacji makroekonomicznej (por. Dotsey, King, Wolman, 1999; Golosov, Lucas, 2003; Gertel, Leahy, 2006). 
$P_{t}=\left[\left(1-\xi_{p}\right) \int_{0}^{1} p_{t}(i)^{1-\eta} d i+\xi_{p} \int_{0}^{1} p_{t-1}(i)^{1-\eta} d i\right]^{\frac{1}{1-\eta}}$,

gdzie:

$\xi_{p}$ - prawdopodobieństwo, że w danym okresie przedsiębiorstwo nie będzie optymalizowało poziomu cen (odsetek firm nie zmieniających cen w danym okresie),

$$
\xi_{p} \in(0,1) \text {. }
$$

Ponieważ firmy dostosowujące ceny w danym okresie napotkają na takie same warunki i stoją przed jednakowym problemem optymalizacyjnym (por. Woodford, 2003), dla każdego dobra pośredniego $i$ otrzymuje się:

$p_{t}(i)=P_{O P T, t}$,

gdzie:

$P_{O P T, t}$ - cena ustalana w okresie $t$.

Tak więc zachodzi:

$\int_{0}^{1} p_{t}(i)^{1-\eta} d i=P_{O P T, t}{ }^{1-\eta}$,

a równanie (115) można przekształcić do postaci:

$P_{t}=\left[\left(1-\xi_{p}\right) P_{O P T, t}^{1-\eta}+\xi_{p} \int_{0}^{1} p_{t-1}(i)^{1-\eta} d i\right]^{\frac{1}{1-\eta}}$.

Uwzględniając równanie (111) otrzymuje się:

$P_{t}=\left[\left(1-\xi_{p}\right) P_{O P T, t}^{1-\eta}+\xi_{p} P_{t-1}^{1-\eta}\right]^{\frac{1}{1-\eta}}$.

Występowanie przedstawionego mechanizmu dostosowywania się cen powoduje dodatnią zależność między kształtowaniem się inflacji a poziomem aktywności gospodarczej. Im wyższy jest parametr $\xi_{p}$, czyli im mniej firm dostosowuje ceny w danym okresie, tym silniej inflacja oddziałuje na kształtowanie się produkcji (por. Woodford, 2003).

W analizowanym modelu przyjęto upraszczające założenie, że występuje tylko jeden czynnik produkcji, a funkcja produkcji jest postaci:

$y_{t}(i)=l_{t}(i)$, 
gdzie:

$l_{t}(i)$ - nakład pracy przy produkcji $i$-tego dobra pośredniego.

W modelu przyjmuje się ponadto, że gospodarstwa domowe maksymalizują oczekiwaną wartość sumy zdyskontowanych użyteczności, które uzależnione są jedynie od ilości konsumpcji i czasu wolnego. Zatem użyteczność j-tego gospodarstwa domowego jest dana wzorem:

$U=E\left(\sum_{t=0}^{\infty} \beta^{t} u\left(C_{t}^{j}, 1-l_{t}^{j}\right)\right)$,

gdzie:

$C_{t}^{j}$ - konsumpcja dobra finalnego przez $j$-te gospodarstwo domowe,

$l_{t}^{j}-$ czas pracy $j$-te gospodarstwa domowego ${ }^{16}$,

Funkcja użyteczności jest dana wzorem:

$u\left(C_{t}^{j}, 1-l_{t}^{j}\right)=\frac{\left(C_{t}^{j}\right)^{1-\sigma_{c}}}{1-\sigma_{c}}+A \frac{\left(1-l_{t}^{j}\right)^{1-\sigma_{1}}}{1-\sigma_{1}}$,

gdzie:

$A>0, \sigma_{c}, \sigma_{1}>1^{17}$.

Występuje więc stała międzyokresowa elastyczność substytucji konsumpcji oraz stała międzyokresowa elastyczność substytucji czasu wolnego.

Linnemann i Schabert zakładają, że na rynku dóbr i usług wydatki gospodarstw domowych nie mogą przekraczać zasobu pieniądza powiększonego o transfery z budżetu, czyli gospodarstwa domowe stoją przed ograniczeniem dotyczącym bieżących zasobów gotówkowych (cash in-advance constrain):

$P_{t} C_{t}^{j} \leq m_{t}^{j}+\operatorname{Tr}_{t}^{j}$

gdzie:

$m_{t}^{j}$ - zasób pieniądza posiadany przez $j$-te gospodarstwo domowe ${ }^{18}$,

$\mathrm{Tr}_{t}^{j}$ - transfery otrzymywane przez $j$-te gospodarstwo domowe.

Gospodarstwa domowe uzyskują dochody z pracy, zyski z firm działających w warunkach konkurencji monopolistycznej, transfery oraz dochody z odsetek od

${ }^{16} \mathrm{~W}$ modelach nowokeynesistowskich, odmiennie niż w modelach $\mathrm{RBC}$, z reguły indeksuje się gospodarstwa domowe. Zgodnie $\mathrm{z}$ tą konwencją w niniejszym rozdziale, a także w rozdziale czwartym, wielkości z subskryptem $j$ oznaczają wielkości dotyczące $j$-tego gospodarstwa domowego.

${ }^{17}$ Parametr $\sigma_{c}$ stanowi odwrotność międzyokresowej elastyczności substytucji konsumpcji, natomiast parametr $\sigma_{1}-$ czasu wolnego.

${ }^{18}$ Ograniczenie gotówkowe dotyczy zatem jedynie dóbr konsumpcyjnych, a nie inwestycyjnych (por. Cooley, Hansen, 1989; McCandless, 2008). 
obligacji. Gospodarstwa domowe są homogeniczne. Pomijając subskrypty dotyczące poszczególnych gospodarstw domowych otrzymuje się zatem ograniczenie postaci:

$\Delta m_{t+1}+\Delta B_{t+1} \leq P_{t} w_{t} l_{t}+r_{t}^{n} B_{t}+P_{t} \operatorname{Tr}_{t}+\int_{0}^{1} \Omega_{i, t}^{n} d i-P_{t} C_{t}$,

gdzie:

$\Omega_{i, t}^{n}$ - zyski $i$-tej firmy działającej w warunkach konkurencji monopolistycznej (w ujęciu nominalnym),

$m_{t}-$ podaż pieniądza,

$B_{t}$ - zasób obligacji w ujęciu nominalnym ${ }^{19}$.

Maksymalizując sumę zdyskontowanych użyteczności określonych równaniem postaci (122) przy warunkach ograniczających określonych równaniami (123) oraz (124) otrzymuje się warunki konieczne maksymalizacji postaci:

$$
\Lambda_{t}=\frac{C_{t}^{-\sigma_{c}}}{1+r_{t}^{n}},
$$

$$
\Lambda_{t}=\beta E_{t}\left[\frac{\Lambda_{t+1}\left(1+r_{t+1}^{n}\right)}{\frac{P_{t}}{P_{t-1}}}\right],
$$

gdzie:

$\Lambda_{t}-$ mnożnik Lagrange'a.

W modelu, w ramach analizy polityki fiskalnej, zakłada się występowanie wydatków rządowych oraz transferów netto. W rezultacie, uwzględniając podaż pieniądza i obligacje, ograniczenie budżetowe państwa jest dane wzorem:

$P_{t} \operatorname{Tr}_{t}+P_{t} G_{t}+m_{t}+\left(1+r_{t}^{n}\right) B_{t}=B_{t+1}+m_{t+1}$,

gdzie:

$G_{t}$ - wydatki rządowe na zakup dóbr finalnych.

Szoki fiskalne dotyczą poziomu wydatków rządowych, zgodnie ze schematem autoregresyjnym postaci:

$\ln G_{t}=\rho_{G} \ln G_{t-1}+\xi_{G, t}$,

gdzie: $\rho_{G} \in(0,1), \xi_{G, t} \sim N\left(0, \sigma_{\xi, G}{ }^{2}\right)$.

$\mathrm{W}$ analizowanym modelu zakłada się dwie możliwości kształtowania się polityki monetarnej. Jednocześnie wybór wariantu polityki pieniężnej ma istotny

\footnotetext{
${ }^{19}$ Stawka płac, transfery oraz konsumpcja są przedstawione w ujęciu realnym.
} 
wpływ na charakter oddziaływania polityki fiskalnej na gospodarkę. W pierwszym wariancie przyjmuje się, że tempo wzrostu podaży pieniądza jest stałe, czyli podaż jest określona równaniem:

$m_{t+1}=\mu_{m} m_{t}$,

gdzie:

$\mu_{m}$ - stopa wzrostu podaży pieniądza.

Przy takim założeniu dotyczącym polityki pieniężnej otrzymuje się, że szok polegający na zwiększeniu wydatków rządowych prowadzi do wzrostu PKB oraz zatrudnienia, a jedocześnie do obniżenia się poziomu konsumpcji, inflacji i stawki płac. Obniżenie się konsumpcji prywatnej wynika z faktu, że wzrost wydatków rządowych powoduje ograniczenie zasobów w gospodarce i w rezultacie negatywny efekt majątkowy. Negatywny efekt majątkowy z kolei przekłada się na wzrost podaży pracy, a ograniczenie czasu wolnego i konsumpcji prywatnej. Mechanizm wpływu wydatków rządowych na wysokość konsumpcji prywatnej jest w tym przypadku analogiczny jak w modelach nie uwzględniających sztywności nominalnych.

Wzrost wydatków rządowych poprzez oddziaływanie negatywnego efektu majątkowego na podaż pracy i kształtowanie się produkcji wpływa także na obniżenie się stawki płac i inflacji. Jednocześnie, w wyniku zwiększenia wydatków rządowych, rośnie również agregatowy popyt, ponieważ wzrost wydatków rządowych jest wyższy niż ograniczenie prywatnej konsumpcji. Zmiana popytu wywiera $\mathrm{z}$ kolei presję na wzrost cen. Wzrost agregatowego popytu jest jednak niższy niż wzrost agregatowej podaży wynikający z większej podaży pracy, a zatem inflacja ulega obniżeniu. Przy tym, ze względu na występowanie sztywności nominalnych, tylko część firm dostosowuje poziom cen. Pozostałe zmniejszają produkcję przy danym poziomie cen, co prowadzi do zmniejszenia się popytu na pracę i obniżenia się nominalnej stawki płac.

W drugim analizowanym przez Linnemanna i Schaberta wariancie prowadzonej polityki, zakłada się, że władze monetarne ustalają wysokość stopy procentowej. Wysokość stopy procentowej jest ustalana na podstawie oczekiwań dotyczących przyszłego kształtowania się produkcji oraz inflacji, czyli² ${ }^{20}$ :

$\widetilde{r}_{t+1}^{n}=r_{\pi} E_{t}\left(\tilde{\pi}_{t+1}\right)+r_{Y} E_{t}\left(\tilde{y}_{t+1}\right)$,

gdzie:

$\widetilde{r}_{t}^{n}$ - odchylenie nominalnej stopy procentowej od poziomu ustalonego,

$\tilde{\pi}_{t}$ - odchylenie inflacji od celu inflacyjnego,

$r_{\pi}, r_{Y}>0$.

$\mathrm{W}$ modelu analizowany jest szczególny przypadek, gdy $r_{Y}=0$. Oznacza to, że docelowy poziom stopy procentowej nie jest uzależniony od przewidywań co

\footnotetext{
${ }^{20}$ Szerzej na temat stopy procentowej ustalanej na podstawie oczekiwań (reguły Taylora typu forward-looking), por. np. Baranowski (2011).
} 
do kształtowania się produkcji, a ustalany jedynie na podstawie oczekiwań dotyczących inflacji.

Przy założeniu występowania opisanej powyżej reguły polityki pieniężnej, podobniej jak wcześniej, okazuje się, że w wyniku wzrostu wydatków rządowych następuje podniesienie się poziomu zatrudnienia i produkcji, natomiast konsumpcja ulega ograniczeniu. Wpływ ekspansywnej polityki fiskalnej na kształtowanie się inflacji oraz cen czynników produkcji może być w tym przypadku jednak odmienny niż w przypadku wcześniej analizowanej wersji polityki pieniężnej. Co prawda, analogicznie jak w poprzedniej wersji modelu, na skutek wzrostu wydatków rządowych następuje negatywny efekt majątkowy powodujący wzrost podaży, a także zwiększenie się agregatowego popytu. Jednak w sytuacji, gdy bank centralny ustala poziom stopy procentowej, w odpowiedzi na wyższy agregatowy popyt rośnie podaż pieniądza, co sprawia, że firmy zaczynają podnosić ceny. Ze względu na sztywności nominalne nie wszystkie przedsiębiorstwa mogą natychmiast zmienić poziom cen. Część firm zamiast tego dostosowuje poziom produkcji. W rezultacie występowanie sztywności nominalnych powoduje, że na skutek zwiększenia wydatków rządowych produkcja rośnie o wiele bardziej, niż wynikałoby to jedynie z efektu majątkowego.

Wynikające z wyższej produkcji zwiększenie się popytu na pracę wywiera presję na wzrost stawki płac. Jak wskazują Linnemann i Schabert dla niskich wartości parametru $r_{Y} \mathrm{w}$ regule Taylora wzrost popytu na pracę silniej oddziałuje na stawkę płac niż wzrost podaży pracy. W rezultacie stawka płac ulega zwiększeniu ${ }^{21}$.

Podsumowując, w analizowanym modelu nowokeynesistowskim, w którym występują sztywności nominalne cen, zwiększenie wydatków rządowych prowadzi do wzrostu PKB i ograniczenia konsumpcji. Natomiast wpływ polityki fiskalnej na inflację zależy od rodzaju polityki monetarnej. Przy stałej stopie wzrostu podaży pieniądza wzrost wydatków rządowych pociąga za sobą spadek inflacji, natomiast przy ustalaniu przez bank stopy procentowej - może powodować wzrost tempa wzrostu cen.

\subsection{Oddziaływanie wydatków rządowych w warunkach sztywności nominalnych płac}

Brak doskonałej elastyczności płac stanowi jeden z dwóch, obok sztywności cen, podstawowych rodzajów sztywności nominalnych ${ }^{22}$. Występowanie sztywności nominalnych płac w modelach nowej ekonomii keynesistowskiej

${ }^{21}$ Wynika to z faktu, że w przypadku niskich wartości $r_{Y}$ w reakcji na wzrost PKB realna stopa procentowa ulega tylko niewielkiemu podwyższeniu i nie oddziałuje znacząco na poziom agregatowego popytu.

${ }^{22}$ Występowanie sztywności nominalnych płac, podobnie jak w przypadku sztywności nominalnych cen, ma potwierdzenie w licznych badaniach mikroekonomicznych. (por. np. Bewley, 1999; Taylor, 1999; Dickens i in., 2006). 
objaśniane jest głównie na podstawie modeli kontraktów płacowych, które, jak wskazuje Wojtyna (2000), odegrały dużą rolę w stworzeniu warunków do renesansu keynesizmu i rozwoju nowej ekonomii keynesistowskiej ${ }^{23}$.

Efekty polityki fiskalnej w modelu nowej ekonomii keynesistowskiej, w sytuacji występowania sztywności nominalnych płac i kontraktów płacowych, jako pierwsza zbadała Cardia (1995). Przyjęła ona, że co roku część pracowników podpisuje kontrakty dotyczące płac nominalnych. Jednocześnie ceny kształtują się w sposób całkowicie elastyczny ${ }^{24}$. Natomiast w zakresie polityki fiskalnej w analizowanym modelu zakłada się, że:

- na dochody budżetowe składają się jedynie podatki zryczałtowane,

- po stronie wydatkowej budżetu występują jedynie wydatki rządowe na zakup dóbr i usług,

- w każdym okresie występuje równowaga budżetowa,

- szoki fiskalne dotyczą poziomu wydatków rządowych.

W modelu, oprócz zmian w polityce fiskalnej, źródłem niepewności jest czas, w którym wygaśnie kontrakt płacowy. Długość kontraktu jest zmienną stochastyczną, gdzie $\left(1-\alpha_{w}\right)$ oznacza prawdopodobieństwo, że kontrakt płacowy wygaśnie wraz z końcem danego okresu. Zatem udział kontraktów, które trwają co najmniej $i$ okresów wynosi $\left(1-\alpha_{w}\right) \alpha_{w}{ }^{i}$. Natomiast średni czas trwania kontraktu płacowego jest równy $\frac{1}{\left(1-\alpha_{w}\right)}$.

Płaca nominalna ustalona w kontrakcie w okresie $t\left(v_{t}\right)$ dana jest wzorem:

$v_{t}=\left(1-\alpha_{w}\right) \sum_{i=0}^{\infty} \alpha_{w}^{i} E\left(W_{t+i}+\psi_{w}\left(l_{t+i}^{d}-l_{t+i}^{s}\right)\right)$,

gdzie:

$\alpha_{w}$ - prawdopodobieństwo niewygaśnięcia kontraktu płacowego w danym okresie,

$W_{t}$ - nominalna stawka płac,

$l_{t}^{d}-$ popyt na pracę,

$l_{t}^{s}$ - podaż pracy,

$\psi_{w}>0$.

Wysokość kontraktu płacowego zależy od kształtowania się obecnych i przyszłych płac oraz od kształtowania się obecnej i przyszłej nadwyżki popytu nad podażą na rynku pracy. Im większy jest parametr $\psi_{w}$, tym szybciej zbiega wartość

${ }^{23}$ Modele te, skonstruowane przez Fishera (1977), Phelpsa i Taylora (1977) oraz Taylora $(1979,1980)$, dobrze odwzorowywały bowiem występujące w rzeczywistych gospodarkach instytucje oraz wyjaśniały, że nawet przy uwzględnieniu hipotezy racjonalnych oczekiwań może dochodzić do sytuacji, w której płace nie mogą zmieniać się z okresu na okres (por. Wojtyna, 2000).

${ }^{24}$ Wnioski płynące $\mathrm{z}$ modelu, w którym zarówno ceny, jak i płace są ustalane zgodnie ze schematem Calvo znaleźć można w pracy Ercega, Hednersona i Levina (2000), por. też Gali (2008). 
kontraktu płacowego do wysokości płacy, dla której popyt na pracę zrównuje się z podażą pracy.

Bieżący poziom płacy nominalnej jest ważoną sumą wszystkich kontraktów płacowych obowiązujących w okresie $t$, czyli:

$W_{t}=\left(1-\alpha_{w}\right) \sum_{i=0}^{\infty} \alpha_{w}{ }^{i} v_{t-i}$

Na podstawie równań (131) i (132) otrzymuje się zatem:

$$
\begin{aligned}
& v_{t}=\frac{1}{\alpha_{w}} v_{t-1}-\frac{1-\alpha_{w}}{\alpha_{w}}\left[W_{t-1}+\psi_{w}\left(l_{t-1}^{d}-l_{t-1}^{s}\right)\right], \\
& W_{t}=\alpha_{w} W_{t-1}+\left(1-\alpha_{w}\right) v_{t} .
\end{aligned}
$$

W modelu zakłada się, że rzeczywiste zatrudnienie jest określone przez popyt na pracę.

Dla $\alpha_{w}=0$ otrzymuje się:

$$
v_{i}=W_{t},
$$

czyli rynek pracy jest w równowadze w każdym okresie.

Zatem w przypadku gdy $\alpha_{w}=0$ model upraszcza się do modelu doskonale oczyszczającego się rynku, w którym nie występują sztywności nominalne. W modelu zakłada się funkcję produkcji Cobba-Douglasa. Ponadto Cardia przyjmuje, że poszczególne gospodarstwa domowe maksymalizują funkcję użyteczności postaci:

$U=E\left(\sum_{t=0}^{\infty} \beta^{t}\left[\alpha_{1} \ln C_{t}^{j}+\alpha_{2} \mathrm{~h} \frac{m_{t}^{j}}{P_{t}}+\alpha_{3} \ln \left(1-l_{t}^{j}\right)\right]\right)$,

gdzie:

$$
\alpha_{1}, \alpha_{2}, \alpha_{3}>0^{25}
$$

przy ograniczeniu budżetowym, które w ujęciu realnym przyjmuje postać:

$$
k_{t+1}^{j}+\frac{m_{t+1}^{j}}{P_{t+1}}+C_{t}^{j}=\left(1+r_{t}\right) k_{t}^{j}+\left(1-\pi_{t}\right) \frac{m_{t}^{j}}{P_{t}}+W_{t} l_{t}^{j}+T r_{t}^{j},
$$

Gospodarstwa domowe są homogeniczne. Zatem pomijając subskrypty oznaczające poszczególne gospodarstwa domowe otrzymuje się:

${ }^{25}$ Zatem w modelu przyjmuje się, że realny zasób pieniądza wpływa na poziom użyteczności (więcej na temat konsekwencji uwzględnienia zasobu pieniądza w funkcji użyteczności por. np. McCandless, 2008). 
$\left(k_{t+1}+\frac{m_{t+1}}{P_{t+1}}\right)=\left(1+r_{t}\right)\left(k_{t}+\frac{m_{t}}{P_{t}}\right)+\frac{W_{t}}{P_{t}} l_{t}-C_{t}-r_{t}^{n} m_{t}+T r_{t}$

Przyjmując:

$a_{t}=k_{t}+\frac{m_{t}}{P_{t}}$

czyli definiując $a_{t}$ jako finansowy majątek gospodarstw domowych w postaci zasobów kapitału i realnych zasobów pieniądza otrzymuje się:

$a_{t+1}=\left(1+r_{t}\right) a_{t}+\frac{W_{t}}{P_{t}} l_{t}-C_{t}-r_{t}^{n} \frac{m_{t}}{P_{t}}+\operatorname{Tr}_{t}$.

W rezultacie uzyskuje się następujące warunki konieczne maksymalizacji użyteczności:

$C_{t+1}=\beta\left(1+r_{t+1}\right) C_{t}$,

$\frac{m_{t}}{P_{t}}=\frac{\alpha_{2}}{\alpha_{1}} \frac{C_{t}}{r_{t}^{n}}$

$l_{t}^{S}=1-\frac{\alpha_{3}}{\alpha_{1}} C_{t} \frac{P_{t}}{W_{t}}$.

Wykorzystując przedstawiony model Cardia analizuje skutki zmian wydatków rządowych finansowanych zryczałtowanymi podatkami. Okazuje się, że wpływ trwałego zwiększenia wydatków rządowych na gospodarkę zależy od elastyczności podaży pracy względem stawki płac. Jeżeli podaż pracy jest uzależniona od stawki płac, wówczas, w wyniku trwałego zwiększenia wydatków rządowych, następuje wzrost produkcji. Zmniejszenie się majątku gospodarstw domowych pociąga wtedy za sobą obniżenie się konsumpcji oraz czasu wolnego oraz zwiększenie się podaży pracy. Wraz ze wzrostem podaży pracy rośnie krańcowy produkt kapitału, co prowadzi do wzrostu inwestycji. Z symulacji przeprowadzonych przez Cardię dla gospodarki amerykańskiej wynika, że podwyższenie wydatków rządowych o 1\% PKB zwiększa produkcję o ok. 0,8\%. Im mniejszy jest parametr $\psi_{w}$, czyli im kontrakty płacowe słabiej reagują na sytuację na rynku pracy, tym silniejszy jest krótkookresowy wpływ wydatków rządowych na PKB. Dla niskich wartości parametru $\psi_{w}$ następuje , przestrzelenie” produkcji, czyli w krótkim okresie produkcja wzrasta powyżej nowego poziomu w stanie ustalonym.

W przypadku, gdy podaż pracy jest sztywna, wzrost wydatków rządowych powoduje analogiczne obniżenie prywatnej konsumpcji, a zatem w długim okresie 
produkcja pozostaje na niezmienionym poziomie. O ile jednak w przypadku niewystępowania kontraktów płacowych dostosowanie zachowania gospodarstw domowych jest natychmiastowe i produkcja pozostaje na niezmienionym poziomie również w krótkim okresie, o tyle przy występowaniu kontraktów płacowych wzrost wydatków rządowych, nawet przy sztywnej podaży pracy, wywiera krótkookresowy wpływ na produkcję. W okresie dostosowawczym, zanim kontrakty płacowe dostosowują się do nowego poziomu równowagi, wzrost wydatków rządowych powoduje bowiem obniżenie realnej stawki płac i w rezultacie wzrost popytu na pracę oraz produkcji.

$\mathrm{Z}$ modelu Cardii wypływa zatem wniosek, że wprowadzenie sztywności nominalnych płac (kontraktów płacowych) sprawia, że trwały wzrost wydatków rządowych wywiera krótkookresowy wpływ na produkcję nawet przy występowaniu pionowej (sztywnej) podaży pracy.

\subsection{Polityka fiskalna przy występowaniu przyzwyczajeń konsumpcyjnych}

Jak wynika z przedstawionych we wcześniejszej części rozdziału modeli, występowanie sztywności nominalnych cen lub płac nie stanowi warunku dostatecznego, by wzrost wydatków rządowych prowadził do zwiększenia konsumpcji prywatnej (por. też Gali, Lopez-Salido i Valles, 2007). Na kierunek oddziaływania polityki fiskalnej na konsumpcję prywatną istotny wpływ ma natomiast uwzględnienie dodatkowych założeń dotyczących zachowania gospodarstw domowych, obejmujących:

- występowanie przyzwyczajeń konsumpcyjnych (habit persistence), które powodują zachowania inercyjne (por. Abel, 1990; Grabek, Kłos, Utzig-Lenarczyk, $2007)^{26}$,

- występowanie gospodarstw domowych nie posiadających dostępu do rynku kredytowego.

Wnioski wynikające z uwzględnienia w modelu nowokeynesistowskim przyzwyczajeń konsumpcyjnych zostały ukazane w niniejszym podrozdziale. W następnym podrozdziale przedstawione zostały natomiast konsekwencje występowania gospodarstw domowych nie posiadających dostępu do rynku kredytowego.

Wprowadzone przez Abela (1990) założenie dotyczące przyzwyczajeń konsumpcyjnych, oznacza, że gospodarstwa domowe mają pewne nawyki, które sprawiają, że ich zachowania konsumpcyjne cechują się inercją. Zatem użyteczność z konsumpcji zależy nie tylko od poziomu bieżącej konsumpcji, ale także

\footnotetext{
${ }^{26}$ Baranowski (2011) zamiast określenia „przyzwyczajenia konsumenta” stosuje sformułowanie „trwałość nawyków”.
} 
od jej poziomu w okresie wcześniejszym (por. McCallum i Nelson, 1999; Fuhrer, $2000)^{27}$.

Gdy gospodarstwa nabywają poszczególne dobra na podstawie przyzwyczajeń, przedsiębiorstwa, ustalając cenę, muszą uwzględnić, że przyszły poziom popytu uzależniony będzie od obecnej wielkości sprzedaży. Wyższa konsumpcja danego dobra obecnie oznacza, że gospodarstwo domowe będzie także skłonne nabyć większą ilość tego dobra w przyszłości. W rezultacie określanie ceny w przedsiębiorstwie staje się problemem dynamicznym.

Model Ravna, Schmitt-Grohe i Uribe (2006) ukazuje wpływ polityki fiskalnej przy występowaniu przyzwyczajeń konsumpcyjnych. W modelu tym zakłada się, że w gospodarce występuje kontinuum identycznych gospodarstw domowych. Każde gospodarstwo domowe $j(j \in<0,1>)$ maksymalizuje zdyskontowaną wartość oczekiwaną użyteczności w poszczególnych okresach $t$, które uzależnione jest od indeksu zagregowanej konsumpcji oraz czasu wolnego:

$U=E \sum_{t=0}^{\infty} \beta^{t} u\left(C_{t}^{j}-\varepsilon_{t}^{\text {pref }}, 1-l_{t}^{j}\right)$,

gdzie $\varepsilon_{t}^{\text {pref }}$ oznacza egzogeniczne, stochastyczne szoki dotyczące preferencji gospodarstwa domowego, które określone są równaniem:

$\varepsilon_{t}^{\text {pref }}=\rho_{\varepsilon, \text { pref }} \varepsilon_{t-1}^{\text {pref }}+\zeta_{\text {pref }, t}, \zeta_{\text {pref }, t} \sim N\left(0, \sigma_{\zeta, \text { pref }}{ }^{2}\right), \rho_{\varepsilon, \text { pref }} \in(0,1)$.

Gospodarstwo domowe konsumuje koszyk dóbr (indeks zagregowanej konsumpcji) określony wzorem:

$C_{t}^{j}=\left[\int_{0}^{1}\left(c_{i, t}^{j}-a_{v} v_{i, t-1}\right)^{1-\frac{1}{\eta_{c}}} d i\right]^{\frac{1}{1-\frac{1}{\eta_{c}}},}$

gdzie:

$a_{v}$ - parametr określający znaczenie przyzwyczajeń konsumpcyjnych w podejmowaniu decyzji przez gospodarstwa domowe,

$v_{i, t}-$ miara określająca przyzwyczajenia konsumpcyjne dla całej gospodarki dotyczące dobra $i$,

$a_{v}, \in(0,1), \eta_{c} \in(0,1)$.

Miara określająca przyzwyczajenia konsumpcyjne $\left(v_{i, t}\right)$ określona jest równaniem:

$v_{i, t}=\rho_{v, i} v_{i, t-1}+\left(1-\rho_{v, i}\right) c_{i, t}$,

${ }^{27}$ Założenie, że decyzje konsumpcyjne gospodarstw domowych uzależnione są od ich wcześniejszych zachowań dotyczących poziomu konsumpcji, ma szerokie potwierdzenie empiryczne (por. np. Chintagunta, Kyriazidou, Perktold, 2001; Ravn, Schmitt-Grohe, Uribe, 2006). 
gdzie $\rho_{v, i} \in(0,1)$, natomiast $c_{i, t}$ oznacza średni dla całej gospodarki poziom konsumpcji dobra $i$, dany wzorem:

$c_{i, t}=\int_{0}^{1} c_{i, t}^{j} d j$.

Zatem poziom konsumpcji dobra $i$ przez gospodarstwo domowe jest uzależniony od wcześniejszych średnich poziomów konsumpcji tego dobra w gospodarce, które gospodarstwo domowe przyjmuje jako z góry ustalone.

Dla każdego poziomu indeksu zagregowanej konsumpcji gospodarstwo domowe zakupuje koszyk $i$ taki, aby zminimalizować wydatki wynoszące $\int_{0} p_{i, t} c_{i, t}^{j} d i$,
gdzie $p_{i, t}$ oznacza cenę dobra $i$ w okresie $t$.

W rezultacie optymalny poziom ilości dobra $i$ dla każdego gospodarstwa domowego jest dany równaniem:

$c_{i, t}^{j}=\left(\frac{p_{i, t}}{P_{t}}\right)^{-\eta_{c}} C_{t}^{j}+a_{v} v_{i, t-1}$,

gdzie indeks cen $P_{t}$ jest określony wzorem (113).

Agregując indeksy konsumpcji poszczególnych gospodarstw domowych otrzymuje się, że agregatowy popyt konsumpcyjny na dobro $i$ jest dany wzorem:

$c_{i, t}=\left(\frac{p_{i, t}}{P_{t}}\right)^{-\eta_{c}} C_{t}+a_{v} v_{i, t-1}$.

Wydatki rządowe na zakup dobra $i$ są w modelu zdefiniowane jako zmienna egzogeniczna, określona przez proces autoregresyjny postaci:

$g_{i, t}=\rho_{g} g_{i, t-1}+\zeta_{g, t}, \zeta_{g, t} \sim N\left(0, \sigma_{\zeta, g}{ }^{2}\right), \rho_{g} \in(0,1)$,

gdzie:

$g_{i, t}-$ wydatki rządowe na zakup dobra $i$.

Na łączne wydatki rządowe składają się wydatki rządowe na zakup poszczególnych dóbr $i$. Wydatki rządowe finansowane są podatkami niezależnymi od dochodu.

W modelu zakłada się, że celem polityki fiskalnej jest maksymalizacja indeksu wydatków rządowych $\left(G_{t}\right)$ określonego równaniem:

$G_{t}=\left[\int_{0}^{1}\left(g_{i, t}-a_{v} v_{i, t-1}^{g}\right)^{1-\frac{1}{\eta_{c}}} d i\right]^{\frac{1}{1-\frac{1}{\eta_{c}}}}$,

gdzie analogicznie jak w przypadku konsumpcji prywatnej gospodarstw domowych zachodzi: 
$v_{i, t}^{g}=\rho_{v, i} v_{i, t-1}^{g}+\left(1-\rho_{v, i}\right) g_{i, t}$.

Przyjęcie indeksu wydatków rządowych określonego równaniem (152) oznacza, że gospodarstwa domowe tworzą nawyki nie tylko dotyczące konsumpcji prywatnej, ale także konsumpcji publicznej. W efekcie otrzymuje się:

$g_{i, t}=\left(\frac{p_{i, t}}{P_{t}}\right)^{-\eta_{c}} G_{t}+a_{v} v_{i, t-1}^{g}$.

W modelu zakłada się, że przedsiębiorstwa działają w warunkach konkurencji monopolistycznej i wytwarzają dobra zgodnie z następującą funkcją produkcji:

$y_{i, t}=z_{t} k_{t}^{\theta} l_{t}^{1-\theta}-F C$,

gdzie:

$F C$ - koszty stałe, których wprowadzenie do modelu powoduje występowanie rosnących korzyści skali,

$\theta \in(0,1)$.

Występujące w skali całej gospodarki szoki technologiczne $\left(z_{t}\right)$ określone są przez proces autoregresyjny, analogiczny do procesu zdefiniowanego równaniem (5).

W modelu na łączny popyt na $i$-ty produkt firmy składa się popyt konsumpcyjny, popyt inwestycyjny oraz wydatki rządowe na zakup $i$-tego produktu. Zatem, agregatowy popyt na dobro $i\left(y_{i, t}^{d}\right)$ jest określony następującym równaniem ${ }^{28}$ :

$y_{i, t}^{d}=\left(\frac{p_{i, t}}{P_{t}}\right)^{-\eta_{c}}\left(C_{t}+I_{t}+G_{t}\right)+a_{v}\left(v_{i, t-1}+v_{i, t-1}^{g}\right)$.

Na podstawie równania (156) otrzymuje się, że elastyczność cenowa popytu jest procykliczna. Wysokość narzutów (kształtowanie się ceny w porównaniu z kosztem krańcowym) nakładanych przez firmy działające w warunkach konkurencji monopolistycznej jest tym wyższa im niższa jest elastyczność cenowa popytu. Model generuje więc antycykliczne kształtowanie się narzutów, czyli zgodne z wynikami empirycznymi (por. Rotemberg, Woodford, 1999) ${ }^{29}$.

Założenie dotyczące występowania przyzwyczajeń konsumpcyjnych ma istotny wpływ na efekty polityki fiskalnej, w tym przede wszystkim na kierunek oddziaływania wydatków rządowych na realną stawkę płac i konsumpcję prywatną. W modelu, w którym nie występują przyzwyczajenia konsumpcyjne wzrost

\footnotetext{
${ }^{28} \mathrm{Na}$ popyt na dobra inwestycyjne $I_{t}$ nawyki gospodarstw domowych nie mają wpływu.

${ }^{29}$ Odmiennie niż w modelach nie zakładających przyzwyczajeń konsumpcyjnych (por. Rotemberg, Woodford, 1991).
} 
wydatków rządowych zwiększa podaż pracy, co prowadzi do spadku realnej stawki płac. Ravn, Schmitt-Grohe i Uribe, na podstawie symulacji przeprowadzonych dla parametrów skalibrowanych dla gospodarki amerykańskiej, uzyskali, że w przypadku występowania przyzwyczajeń konsumpcyjnych określonych równaniami (146) i (152) zwiększenie wydatków rządowych prowadzi natomiast do wzrostu realnej stawki płac. Wynika to z faktu, że podniesienie wydatków rządowych oddziałuje na ograniczenie narzutu i silny wzrost popytu na pracę (por. Hall, 2009). Wyższy popyt na pracę powoduje z kolei podniesienie się realnej stawki płac. Jak wynika z symulacji przeprowadzonych przez Ravna, Schmitt-Grohe i Uribe oddziaływanie popytu na pracę na stawkę płac jest silniejsze niż wpływ, jaki wywiera na realną stawkę płac wyższa podaż pracy. W rezultacie uwzględnienie występowania przyzwyczajeń konsumpcyjnych sprawia, że zwiększenie wydatków rządowych prowadzi do wzrostu realnej stawki płac.

Występowanie przyzwyczajeń konsumpcyjnych oddziałuje ponadto na kierunek zależności pomiędzy wydatkami rządowymi a konsumpcją prywatną. W przypadku, gdy nie występują przyzwyczajenia konsumpcyjne, wzrost wydatków rządowych pociąga za sobą obniżenie konsumpcji prywatnej, co wynika z pojawienia się negatywnego efektu majątkowego. Natomiast w przypadku występowania przyzwyczajeń konsumpcyjnych oprócz efektu majątkowego ma również miejsce silny efekt substytucyjny - w wyniku wzrostu realnej stawki płac gospodarstwa domowe zastępują czas wolny konsumpcją. Jak wynika z symulacji, które na podstawie wartości parametrów typowych dla gospodarki amerykańskiej przeprowadzili Ravn, Schmitt-Grohe i Uribe, efekt dochodowy jest w tym przypadku słabszy niż efekt substytucyjny. W konsekwencji podniesienie wydatków rządowych powoduje, że zwiększeniu ulega również konsumpcja prywatna. Uwzględnienie przyzwyczajeń konsumpcyjnych polepsza więc właściwości statystyczne modelu, ponieważ dane empiryczne wskazują na występowanie dodatniej zależności pomiędzy konsumpcją prywatną a publiczną (por. Blanchard, Perotti 2002; Perotti, 2002; Gali, Lopez-Salido, Valles, 2007).

\subsection{Implikacje występowania gospodarstw niericardiańskich}

W podstawowym modelu nowokeynesistowskim zakłada się, że gospodarstwa domowe mają dostęp do doskonałego rynku finansowego. W rezultacie bieżący dochód nie ogranicza konsumpcji gospodarstw domowych, które decyzje konsumpcyjne podejmują na podstawie międzyokresowego ograniczenia budżetowego. W takim przypadku bieżący dochód jedynie w nieznacznym stopniu oddziałuje na decyzje konsumpcyjne gospodarstw domowych. Jak wynika jednak z badań empirycznych, bieżący dochód wywiera istotny wpływ na bieżącą konsumpcję gospodarstw domowych (por. np. Campbell, Mankiw, 1989; Deaton, 
1992; Johnson, Parker, Souleles, 2004). Z tego względu, zdaniem Mankiwa (2000), wskazane jest uwzględnienie w modelach nowej ekonomii keynesistowskiej podmiotów, które ze względu m.in. na brak dostępu do rynku kredytowego określają poziom konsumpcji na podstawie bieżącego dochodu ${ }^{30}$. Efekty polityki fiskalnej w przypadku występowania zarówno gospodarstw domowych zachowujących się zgodnie z międzyokresowym ograniczeniem budżetowym (gospodarstw ricardiańskich), jaki i gospodarstw domowych opierających swoje decyzje na bieżącym dochodzie (gospodarstw niericardiańskich) ukazuje model Galego, Lopez-Salido i Vallesa (2007). W modelu zakłada się występowanie sztywności nominalnych cen, zgodnie ze schematem Calvo (1983). Przedsiębiorstwa wytwarzają nieskończenie wiele dóbr pośrednich, które są przetwarzane na dobra finalne. Występuje kontinuum gospodarstwa domowych, $j \in<0,1>$, z których $\lambda$ podejmuje decyzje na podstawie bieżącego dochodu, natomiast $1-\lambda$ na podstawie międzyokresowego ograniczenia budżetowego. Gali, Lopez-Salido i Valles zakładają, że funkcja chwilowej użyteczności ricardiańskich gospodarstw domowych ma postać:

$u\left(C_{t}^{R}, l_{t}^{R}\right)=\ln C_{t}^{R}-\frac{\left(l_{t}^{R}\right)^{1+\varphi}}{1+\varphi}$,

gdzie $C_{t}^{R}$ oraz $l_{t}^{R}$ oznacza odpowiednio poziom konsumpcji dóbr finalnych oraz czas pracy gospodarstw ricardiańskich, $\varphi \geq 0$.

Gospodarstwa ricardiańskie biorą pod uwagę nie tylko bieżącą użyteczność, ale także przyszłe zdyskontowane użyteczności, a więc maksymalizują wyrażenie:

$U^{R}=E_{t}\left(\sum_{t=0}^{\infty} \beta^{t}\left(\ln C_{t}^{R}-\frac{\left(l_{t}^{R}\right)^{1+\varphi}}{1+\varphi}\right)\right)$.

Gospodarstwa ricardiańskie dla każdego $t$ stoją przed następującym ograniczeniem budżetowym:

$$
P_{t}\left(C_{t}^{R}+I_{t}^{R}\right)+\frac{B_{t+1}^{R}}{\left(1+r_{t}^{n}\right)}+P_{t} T_{t}^{R}=w_{t} P_{t} l_{t}^{R}+\left(1+r_{t}^{k}\right) P_{t}^{R} k_{t}^{R}+B_{t}^{R}+D_{t}^{R},
$$

gdzie:

$I_{t}^{R}$ - inwestycje gospodarstw ricardiańskich,

$k_{t}^{R}$ - kapitał posiadany przez gospodarstwa ricardiańskie,

${ }^{30}$ Do innych potencjalnych przyczyn tego typu zachowania gospodarstw domowych zaliczyć można np. krótkowzroczność czy strach przed oszczędzaniem (por. Gali, Lopez-Salido, Valles, 2007). 
$B_{t}^{R}$ - liczba jednookresowych obligacji przynoszących jednostkową płatność w okresie $t$, posiadanych przez gospodarstwa ricardiańskie na koniec okresu $t-1$, $r_{t}^{k}-$ stopa zwrotu z kapitału,

$D_{t}^{R}$ - dywidendy wypłacane będących właścicielami firm gospodarstwom ricardiańskim,

$T_{t}^{R}$ - podatki zryczałtowane płacone przez gospodarstwa ricardiańskie.

Równanie przyrostu kapitału Gali, Lopez-Salido i Valles określają równaniem:

$k_{t+1}^{R}=(1-\delta) k_{t}^{R}+f\left(\frac{I_{t}^{R}}{k_{t}^{R}}\right) k_{t}^{R}$,

gdzie:

$f^{\prime}>0, f^{\prime \prime}<0, f(\delta)=\delta, f^{\prime}(\delta)=1$.

$\mathrm{W}$ rezultacie, w przypadku ricardiańskich gospodarstw domowych otrzymuje się następujące warunki konieczne maksymalizacji wartości oczekiwanej sumy zdyskontowanych użyteczności:

$E_{t}\left(\beta \frac{C_{t}^{R}}{C_{t+1}^{R}}\right)=\frac{1}{1+r_{t}^{n}}$

$E_{t}\left(\beta \frac{C_{t}^{R}}{C_{t+1}^{R}}\left(1+r_{t+1}^{k}+Q_{T, t+1}\left(1-\delta+f\left(\frac{I_{t+1}^{R}}{k_{t+1}^{R}}\right)-\frac{I_{t+1}^{R}}{k_{t+1}^{R}} f^{\prime}\left(\frac{I_{t+1}^{R}}{k_{t+1}^{R}}\right)\right)\right)\right)=P_{t} Q_{T, t}$,

gdzie:

$$
Q_{T, t}=\frac{1}{f^{\prime}\left(\frac{I_{t}^{R}}{k_{t}^{R}}\right)},
$$

a zatem $Q_{T, t}$ oznacza współczynnik Q-Tobina.

Postać chwilowej funkcji użyteczności gospodarstw niericardiańskich jest analogiczna jak w przypadku gospodarstw ricardiańskich. Gospodarstwa niericardiańskie biorą jednak pod uwagę jednie użyteczność w bieżącym okresie, czyli maksymalizują wyrażenie:

$U^{N R}=\ln C_{t}^{N R}-\frac{\left(l_{t}^{N R}\right)^{1+\varphi}}{1+\varphi}$,

gdzie $C_{t}^{N R}$ oraz $l_{t}^{N R}$ oznacza odpowiednio poziom konsumpcji oraz czas pracy gospodarstw niericardiańskich.

Gospodarstwa niericardiańskie konsumują w każdym okresie cały posiadany dochód, czyli w ich przypadku ograniczenie budżetowe przyjmuje postać: 
$P_{t} C_{t}^{N R}+P_{t} T_{t}^{N R}=w_{t} P_{t} l_{t}^{R}$,

gdzie $T_{t}^{N R}$ oznacza podatki zryczałtowane płacone przez gospodarstwa niericardiańskie.

Równanie (165) można również zapisać w ujęciu realnym, czyli w postaci:

$C_{t}^{N R}=w_{t} l_{t}^{R}-T_{t}^{N R}$.

Dokonując agregacji wszystkich gospodarstw otrzymuje się:

$C_{t}=\lambda C_{t}^{N R}+(1-\lambda) C_{t}^{R}$,

$l_{t}=\lambda l_{t}^{N R}+(1-\lambda) l_{t}^{R}$,

$I_{t}=(1-\lambda) I_{t}^{R}$,

$k_{t}=(1-\lambda) k_{t}^{R}$.

Ponieważ gospodarstwa niericardiańskie konsumują cały dochód w każdym okresie, zatem całkowite inwestycje wynikają jedynie z inwestycji ponoszonych przez gospodarstwa ricardiańskie. W rezultacie są one właścicielami całego kapitału w gospodarce, a także wszystkich obligacji w gospodarce.

W modelu przyjmuje się, że polityka fiskalna poprzez podatki może w odmienny sposób oddziaływać na każdą grupę gospodarstw. Gali, Lopez-Salido i Valles zakładają przy tym, że występują jedynie podatki zryczałtowane, niezależne od dochodu. Na łączne podatki składają się zatem podatki zryczałtowane płacone przez gospodarstwa ricardiańskie oraz niericardiańskie:

$T_{t}=\lambda T_{t}^{N R}+(1-\lambda) T_{t}^{R}$.

$\mathrm{W}$ analizowanym modelu przyjmuje się ponadto, że odchylenia udziału wydatków rządowych w PKB od poziomu długookresowej równowagi są określone przez proces autoregresyjny pierwszego rzędu. Zatem:

$\frac{G_{t}-G^{*}}{Y^{*}}=\rho_{g / y} \frac{G_{t-1}-G^{*}}{Y^{*}}+\xi_{t}$,

gdzie $G^{*}$ oraz $Y^{*}$ oznaczają długookresowe poziomy w stanie ustalonym odpowiednio wydatków rządowych oraz PKB, $\rho_{g / y}>0$.

Władze fiskalne kształtują podatki zgodnie z następującą regułą fiskalną:

$T_{t}-T^{*}=\phi_{g / y}\left(G_{t}-G^{*}\right)+\phi_{B / y}\left(\frac{B_{t}}{P_{t-1}}-\frac{B^{*}}{P^{*}}\right)$, 
gdzie:

$T^{*}, B^{*}, P^{*}$ - odpowiednio podatki zryczałtowane, obligacje oraz poziom cen w stanie ustalonym,

$$
\begin{aligned}
& \phi_{g / y} \in<0,1>, \\
& \phi_{B / y}>0 .
\end{aligned}
$$

Zatem władze fiskalne utrzymują podatki na tym wyższym poziomie, im wyższe są wydatki rządowe oraz realny poziom zadłużenia państwa w stosunku do poziomów w stanie ustalonym.

W modelu analizowane są dwa alternatywne warianty rynku pracy:

- rynek pracy doskonale konkurencyjny,

- rynek pracy, na którym poziom płac określają związki zawodowe.

W przypadku rynku doskonale konkurencyjnego warunek konieczny optymalizacji jest taki sam dla obu rodzajów gospodarstw domowych:

$$
\begin{aligned}
& w_{t}^{R}=C_{t}^{R}\left(l_{t}^{R}\right)^{\varphi}, \\
& w_{t}^{N R}=C_{t}^{N R}\left(l_{t}^{N R}\right)^{\varphi} .
\end{aligned}
$$

Jeżeli wynagrodzenia są ustalane przez związki zawodowe, wówczas o poziomie zatrudnienia (czasie pracy danego gospodarstwa domowego) decyduje kształtowanie się popytu na pracę przy danej stawce płac. W modelu zakłada się, że poziom produkcji zależy od efektywnego poziomu zatrudnienia $l_{t}$, na który ma wpływ zatrudnienie w poszczególnych zawodach $j$, zgodnie z funkcją CES postaci:

$l_{t}=\left[\int_{0}^{1}\left(l_{j, t}\right)^{\frac{\eta_{w}-1}{\eta_{w}}} d j\right]^{\frac{\eta_{w}}{\eta_{w}-1}}$

gdzie:

$l_{j, t}$ - popyt na pracę w zawodzie $j$,

$\eta_{w}$-elastyczność substytucji pomiędzy poszczególnymi rodzajami zawodów.

Zatem poziom popytu na pracę $\mathrm{w}$ danym zawodzie określa równanie:

$l_{j, t}=\left(\frac{w_{j, t}}{w_{t}}\right)^{-\eta_{w}} l_{t}$

gdzie:

$w_{j, t}$ - stawka płac w zawodzie $j$.

Związki zawodowe poziom płac w danym zawodzie $j$ ustalają na takim poziomie by maksymalizować następującą funkcję celu:

$U\left(w_{j, t}\right)=\lambda\left(u_{C, t}^{N R} w_{j, t} l_{j, t}^{N R}-\frac{\left(l_{t}^{N R}\right)^{1+\varphi}}{1+\varphi}\right)+(1-\lambda)\left(u_{C, t}^{R} w_{j, t} l_{j, t}^{R}-\frac{\left(l_{t}^{R}\right)^{1+\varphi}}{1+\varphi}\right)$ 
gdzie:

$u_{C, t}^{N R}-$ krańcowa użyteczność konsumpcji w przypadku gospodarstw niericardiańskich,

$u_{C, t}^{R}$ - krańcowa użyteczność konsumpcji w przypadku gospodarstw ricardiańskich.

Przedsiębiorstwa, określając popyt na pracę, nie różnicują gospodarstw domowych, zatem przy danej stawce płac zachodzi:

$l_{j, t}^{R}=l_{j, t}^{N R}=l_{t}$,

czyli poziom zatrudnienia (czas pracy) jest jednakowy dla gospodarstw ricardiańskich i niericardiańskich. Równanie (178) można więc uprościć do postaci:

$U\left(w_{j, t}\right)=w_{j, t} l_{j, t}\left(\lambda u_{C, t}^{N R}+(1-\lambda) u_{C, t}^{R}\right)-\frac{\left(l_{t}\right)^{1+\varphi}}{1+\varphi}$.

Przy założonej funkcji użyteczności zachodzi:

$$
\begin{aligned}
& u_{C}^{N R}=\frac{1}{C_{t}^{N R}}, \\
& u_{C}^{R}=\frac{1}{C_{t}^{R}},
\end{aligned}
$$

a zatem równanie (180) można przekształcić do postaci:

$$
U\left(w_{j, t}\right)=w_{j, t} l_{j, t}\left(\frac{\lambda}{C_{t}^{R}}+\frac{1-\lambda}{C_{t}^{N R}}\right)-\frac{\left(l_{t}\right)^{1+\varphi}}{1+\varphi} .
$$

W rezultacie związki zawodowe ustalają stawkę płac na takim poziomie, by spełniony był warunek:

$$
\left(\frac{\lambda}{c_{t}^{N R}\left(l_{t}\right)^{\varphi}}+\frac{1-\lambda}{c_{t}^{N R}\left(l_{t}\right)^{\varphi}}\right) w_{t}=\frac{\eta_{w}}{1-\eta_{w}} .
$$

Gali, Lopez-Salido i Valles na podstawie symulacji dla każdego z wariantów rynku pracy analizują oddziaływanie wzrostu wydatków rządowych na kształtowanie się zmiennym makroekonomicznych, w tym, w szczególności, konsumpcji prywatnej. Parametry modelu oszacowane zostały na podstawie danych dla gospodarki amerykańskiej oraz na podstawie literatury (por. King i Watson, 1996; Rotemberg i Woodford, 1999; Mankiw, 2000).

Z przeprowadzonych przez autorów symulacji wynika, że na otrzymane wyniki istotny wpływ ma udział gospodarstw niericardiańskich w ogóle gospodarstw domowych. Dla każdego z analizowanych rynków pracy wraz ze wzrostem udziału 
gospodarstw zwiększeniu ulega siła pozytywnego oddziaływania wydatków rządowych na produkcję. W przypadku występowania doskonale konkurencyjnego rynku pracy mnożnik wydatków rządowych jest wyższy od jedności, jeśli udział gospodarstw niericardiańskich jest nie mniejszy niż 65\%. Natomiast w sytuacji, gdy rynek pracy nie jest doskonale konkurencyjny, lecz określony przez działanie związków zawodowych, wówczas mnożnik wydatków rządowych zaczyna być wyższy od jedności już od momentu, gdy udział gospodarstw niericardiańskich zaczyna przekraczać $25 \%$.

Również reakcja konsumpcji prywatnej na wzrost wydatków rządowych jest uzależniona od udziału gospodarstw niericardiańskich w gospodarce. Dla doskonale konkurencyjnego rynku pracy, jeżeli udział gospodarstw niericardiańskich jest niższy niż $60 \%$, wówczas wzrost wydatków rządowych, podobnie jak w standardowym modelu nowokeynesistowskim, powoduje ograniczenie konsumpcji prywatnej. Jednak gdy gospodarstwa niericardiańskie stanowią ponad $60 \%$ populacji, wówczas na podstawie modelu otrzymuje się dodatnią zależność pomiędzy wydatkami rządowymi a konsumpcją prywatną, czyli zależność zgodną z danymi empirycznymi. W sytuacji, gdy na rynku pracy działają związki zawodowe, wystarczy niewielki, wynoszący co najmniej $20 \%$, odsetek niericardiańskich gospodarstw domowych, by podniesienie wydatków rządowych skutkowało wzrostem konsumpcji prywatnej.

$\mathrm{Z}$ modelu wynika również, że warunkiem występowania dodatniej zależności pomiędzy wydatkami rządowymi a konsumpcją prywatną jest także występowanie sztywności nominalnych. Jeżeli nie występują sztywności nominalne, wówczas nawet w przypadku dużego udziału gospodarstw niericardiańskich w populacji wzrost wydatków rządowych prowadzi do ograniczenia konsumpcji prywatnej. W przypadku sztywności płac wzrost wydatków rządowych zwiększa bowiem agregatowy popyt, który z kolei oddziałuje na wzrost realnej stawki płac. Wyższy bieżący dochód oddziałuje na wzrost konsumpcji w przypadku niericardiańskiej części gospodarstw domowych. Zatem kierunek oddziaływania wydatków rządowych na konsumpcję prywatną uzależniony jest od występowania sztywności nominalnych oraz udziału gospodarstw domowych, których konsumpcja uzależniona jest od ich bieżącego dochodu (por. też. Bouakez, Rebei, 2007). Ponadto brak występowania sztywności nominalnych osłabia siłę oddziaływania wydatków rządowych na PKB.

W analizowanym modelu zakłada się, że podatki zryczałtowane dostosowują się w reakcji na wzrost wydatków rządowych oraz obligacji (por. równanie (173)). Im silniejsza reakcja podatków na wzrost wydatków rządowych, tym niższy wzrost deficytu budżetowego następujący bezpośrednio po zmianie polityki fiskalnej. To w jakim stopniu wyższe wydatki rządowe są w początkowym okresie finansowane $\mathrm{z}$ deficytem, a w jakim podatkami, ma istotny wpływ na reakcję produkcji i konsumpcji prywatnej na zmiany polityki fiskalnej. Jeśli gospodarstwa dzielą się po równo na gospodarstwa ricardiańskie i niericardiańskie, a wydatki 
są początkowo głownie finansowane deficytem budżetowym, wówczas mnożnik wydatków rządowych jest wyższy od jedności i występuje dodatnia zależność między wydatkami rządowymi a konsumpcją prywatną. Przy analogicznym założeniu dotyczącym gospodarstw domowych, lecz w sytuacji, gdy podwyżce wydatków rządowych od razu towarzyszy znaczny wzrost opodatkowania niedopuszczający do powstania deficytu budżetowego, mnożnik wydatków rządowych jest mniejszy od jedności, a zależność pomiędzy wydatkami rządowymi ma charakter ujemny. Zatem sposób finansowania wydatków rządowych wywiera w tym przypadku istotny wpływ na charakter oddziaływania polityki fiskalnej.

\section{Podsumowanie}

Modele nowej ekonomii keynesistowskiej, zwane inaczej modelami nowej syntezy neoklasycznej, zakładając występowanie sztywności nominalnych w gospodarce, umożliwiają uwzględnienie popytowego oddziaływania polityki fiskalnej. Jednocześnie opierają się one na podstawach mikroekonomicznych, czyli reakcja gospodarki na zmiany polityki fiskalnej wynika z decyzji optymalizacyjnych gospodarstw domowych i przedsiębiorstw. Nowa synteza neoklasyczna stanowi więc połączenie neoklasycznej metodologii dynamicznych modeli równowagi ogólnej z keynesistowskim założeniem dotyczącym krótkookresowych sztywności nominalnych w gospodarce. W rezultacie, w modelach nowej ekonomii keynesistowskiej polityka fiskalna oddziałuje na fluktuacje gospodarcze zarówno poprzez efekt majątkowy, jak i efekt popytowy, wynikający ze sztywności nominalnych w gospodarce.

Jak wskazują Linnemann i Schabert (2003) w przypadku występowania jedynie sztywności nominalnych cen wpływ polityki fiskalnej na gospodarkę uzależniony jest $\mathrm{w}$ znacznym stopniu od sposobu prowadzenia polityki pieniężnej. W szczególności charakter polityki pieniężnej rzutuje na kierunek oddziaływania wydatków rządowych na inflację. Przy stałej stopie wzrostu podaży pieniądza zwiększenie wydatków rządowych pociąga za sobą obniżenie się tempa wzrostu cen. Natomiast jeśli bank centralny, zgodnie z regułą Taylora, ustala poziom stopy procentowej, wówczas wzrost wydatków rządowych prowadzić może do podniesienia się poziomu inflacji. Ponadto, w przypadku ustalania przez bank centralny stopy procentowej, siła oddziaływania polityki fiskalnej na PKB jest większa efekt popytowy znacznie wzmacnia działanie efektu podażowego.

Cardia (1995) ukazuje, że na siłę oddziaływania polityki fiskalnej na gospodarkę wpływa również występowanie sztywności nominalnych płac. Im kontrakty płacowe słabiej reagują na sytuację na rynku pracy, tym większe są skutki zmian wydatków rządowych. Przy występowaniu sztywności nominalnych płac wzrost wydatków rządowych wywiera krótkookresowy wpływ na produkcję nawet przy 
sztywnej podaży pracy. W okresie dostosowawczym, zanim kontrakty płacowe dopasują się do nowego poziomu równowagi, wzrost wydatków rządowych powoduje bowiem obniżenie się realnej stawki płac i w rezultacie wzrost popytu na pracę oraz produkcji.

Efekty popytowe wynikające ze zwiększenia wydatków rządowych oddziałują na wzrost konsumpcji prywatnej. Jednocześnie jednak negatywny efekt majątkowy ma wpływ na jej ograniczenie. Dlatego występowanie jedynie sztywności nominalnych nie stanowi wystarczającego warunku, by wzrost wydatków rządowych przekładał się na zwiększenie się konsumpcji prywatnej. Potwierdzają to analizy Galego, Lopez-Salido i Vallesa (2007).

$\mathrm{Na}$ charakter oddziaływania polityki fiskalnej na konsumpcję prywatną istotny wpływ ma występowanie wśród gospodarstw domowych przyzwyczajeń konsumpcyjnych. Ravn, Schmitt-Grohe i Uribe (2006) wykazali, że jeśli zachowania konsumpcyjne gospodarstw domowych cechują się inercją, to zwiększenie wydatków rządowych prowadzi do wzrostu realnej stawki płac. Wynika to z faktu, że podniesienie wydatków rządowych wpływa wówczas na znaczne ograniczenie narzutu nakładanego na ceny przez przedsiębiorstwa i w rezultacie na wzrost popytu na pracę. W wyniku zwiększenia się realnej stawki pojawia się z kolei silny efekt substytucyjny - gospodarstwa domowe zastępują czas wolny konsumpcją. W rezultacie podniesienie wydatków rządowych sprawia, że zwiększeniu ulega również konsumpcja prywatna.

Symulacje, które przeprowadzili Gali, Lopez-Salido i Valles (2007) pokazują, że na kierunek oddziaływania polityki fiskalnej na konsumpcję prywatną wpływ ma również udział gospodarstw domowych nieposiadających dostępu do rynku kredytowego. Jeśli w gospodarce, w której występują sztywności nominalne, gospodarstwa niericardiańskie stanowią ponad $60 \%$ populacji, wówczas wzrost wydatków rządowych prowadzi do zwiększenia się konsumpcji prywatnej. Gdy uwzględni się możliwość występowania związków zawodowych, wówczas nawet przy niewielkim odsetku gospodarstw niericardiańskich uzyskuje się dodatnią zależność między wydatkami rządowymi a konsumpcją prywatną. Występowanie gospodarstw niericardiańskich ma też wpływ na siłę oddziaływania wydatków rządowych na produkcję. Im większy udział gospodarstw niericardiańskich, tym silniejsze popytowe efekty polityki fiskalnej i wyższy mnożnik wydatków rządowych. 



\section{Ocena podażowych skutków szoków fiskalnych na podstawie modelu realnego cyklu koniunkturalnego dla gospodarki polskiej}

\section{Wprowadzenie}

W niniejszym rozdziale, na podstawie modelu realnego cyklu koniunkturalnego, poddano analizie podażowe oddziaływanie polityki fiskalnej w Polsce. Podstawę teoretyczną oszacowania efektów podażowych zmian wydatków rządowych i podatków w gospodarce polskiej stanowi model Hansena (1985) z niepodzielną pracą, rozszerzony o dodatkowe założenia dotyczące występowania polityki fiskalnej. Wybór modelu podyktowany został następującymi przesłankami:

- w modelu na sferę realną oddziałuje jedynie podażowa strona gospodarki, co umożliwia wyodrębnienie podażowych efektów zmian w wydatkach rządowych i podatkach,

- przyjęcie założenia o niepodzielnej pracy powoduje, że model nie generuje dużych wahań podaży pracy w wyniku zmian stawki płac i w rezultacie w większym stopniu niż model z podzielną pracą odpowiada rzeczywistemu rynkowi pracy,

- model Hansena jest jednym z częściej analizowanych modeli realnego cyklu koniunkturalnego, co umożliwia dokonywanie porównań z innymi badaniami, np. dla gospodarki polskiej - z wynikami Kuchty i Piłat (2010).

Zaprezentowany $\mathrm{w}$ dalszej części rozdziału model stanowi rozwinięcie modelu Hansena o występowanie wydatków rządowych oraz podatków. W modelu Hansena jedyne źródło zaburzeń stanowią bowiem szoki technologiczne, natomiast w zastosowanym modelu występują również szoki fiskalne, dotyczące poziomu wydatków rządowych oraz stóp podatkowych. Założenia dotyczące polityki fiskalnej opierają się na przedstawionych w pierwszym rozdziale pracach Aschauera (1988), Christiano i Eichenbauma (1992), Baxter i Kinga (1993) oraz McGrattan (1994). Na podstawie modelu Aschauera (1988) oraz Christiano i Eichenbauma (1992) wprowadzono założenie dotyczące substytucyjności pomiędzy konsumpcją prywatną a publiczną. Dotyczące funkcji produkcji założenia zawarte w modelu Baxter i Kinga (1993) uwzględniono w celu analizy wpływu majątkowych wydatków inwestycyjnych i kapitału publicznego na wysokość produkcji. Z kolei opierając się na pracy McGrattan (1994) poddano analizie występowanie podatków nakładanych na dochody z kapitału i pracy. Ponadto, w celu określenia podażowych skutków polityki fiskalnej w ramach cyklu, uwzględniono możliwość pro- lub antycyklicznego kształtowania się wydatków rządowych oraz podatków. 
Model, na którego podstawie oszacowano podażowe skutki polityki fiskalnej w Polsce, różni się od oryginalnego modelu Hansena nie tylko z powodu uwzględnienia w nim szoków fiskalnych, ale także wartościami parametrów. W modelu Hansena występują wartości parametrów typowe dla gospodarki amerykańskiej, natomiast parametry analizowanego $\mathrm{w}$ rozdziale modelu oszacowano na podstawie danych dla gospodarki polskiej.

W pierwszej kolejności, ukazane zostały założenia modelu oraz oszacowania uzyskanych dla gospodarki polskiej parametrów. Następnie, na podstawie opracowanego modelu, analizie poddane zostały efekty zwiększenia wydatków rządowych finansowanych zryczałtowanymi podatkami oraz skutki zmian stóp podatkowych. Rozdział kończy się pokazaniem konsekwencji zmiany sposobu finansowania wydatków rządowych oraz przedstawieniem wniosków z przeprowadzonej analizy.

\subsection{Założenia i parametry modelu}

W opracowanym dla gospodarki polskiej modelu realnego cyklu koniunkturalnego przyjęto, że wartość oczekiwana sumy zdyskontowanych użyteczności gospodarstw domowych jest określona wzorem postaci:

$U=E\left(\sum_{t=0}^{\infty} \beta^{t}\left(\ln \left(c_{t}^{e}+A h_{t}\right)\right)\right.$

gdzie:

$A>0, \beta \in(0,1)$.

W funkcji użyteczności założono zatem występowanie niepodzielnej pracy. Wynikająca z modelu z podzielną pracą silna międzyokresowa substytucja podaży pracy nie ma bowiem potwierdzenia $\mathrm{w}$ badaniach empirycznych (por. np. Romer, 2000).

Analogicznie jak u Aschauera (1988) oraz Christiano i Eichenbauma (1992) założono, że efektywna konsumpcja uzależniona jest od konsumpcji prywatnej i bieżących wydatków rządowych, czyli:

$c_{t}^{e}=c_{t}+\gamma g_{t}^{B}$,

gdzie:

$\gamma \in<0,1>$.

W rezultacie funkcja użyteczności przyjmuje postać ${ }^{1}$ :

${ }^{1}$ Funkcja użyteczności jest więc zbliżona do funkcji określonej równaniem (74), przedstawionej w pierwszym rozdziale pracy. W opracowanym dla gospodarki polskiej modelu uwzględniono dodatkowo występowanie majątkowych wydatków rządowych, zatem w równaniu (187) zawarto, że na poziom użyteczności wpływają jedynie bieżące wydatki rządowe. 


$$
U=E\left(\sum_{t=0}^{\infty} \beta^{t}\left(\ln \left(c_{t}+\gamma g_{t}^{B}\right)+A h_{t}\right)\right) .
$$

$\mathrm{Na}$ wydatki publiczne składają się bieżące wydatki rządowe, inwestycyjne wydatki rządowe oraz transfery ${ }^{2}$. Natomiast spośród dochodów publicznych wyodrębniono podatki proporcjonalne do wysokości dochodu oraz podatki zryczałtowane. W rezultacie otrzymuje się:

$$
\sum_{t=1}^{\infty} \frac{\tau_{t} y_{t}+T_{t}}{\pi_{j=1}^{t}\left(1+\left(1-\tau_{j}\right) r_{j}\right)}=\sum_{t=1}^{\infty} \frac{g_{t}^{B}+i_{t}^{G}+T r_{t}}{\pi_{j=1}^{t}\left(1+\left(1-\tau_{j}\right) r_{j}\right)},
$$

gdzie:

$$
\pi_{j=1}^{t}\left(1+\left(1-\tau_{j}\right) r_{j}\right)=\left(1+\left(1-\tau_{1}\right) r_{1}\right)\left(1+\left(1-\tau_{2}\right) r_{2}\right) \ldots\left(1+\left(1-\tau_{t}\right) r_{t}\right) .
$$

W modelu założono, że bieżące i inwestycyjne wydatki rządowe stanowią stałą część wydatków publicznych:

$g_{t}^{B}=\alpha^{B} g_{t}$,

$i_{t}^{G}=\left(1-\alpha^{B}\right) g_{t}$,

gdzie:

$$
\alpha^{B} \in(0,1)
$$

Zasób kapitału publicznego $\left(k_{t}^{G}\right)$ określony jest przez standardowe równanie przyrostu kapitału, czyli:

$$
k_{t+1}^{G}=(1-\delta) k_{t}^{G}+\left(1-\alpha^{B}\right) g_{t},
$$

gdzie:

$\delta \in(0,1)$.

Ograniczenie budżetowe gospodarstw domowych jest postaci:

$$
k_{0}+\sum_{t=1}^{\infty} \frac{\left(1-\tau_{t}\right) w_{t} l_{t}-T_{t}+\operatorname{Tr}_{t}}{\pi_{j=1}^{t}\left[1+\left(1-\tau_{j}\right) r_{j}\right]}=\sum_{t=1}^{\infty} \frac{c_{t}}{\pi_{j=1}^{t}\left[1+\left(1-\tau_{j}\right) r_{j}\right]} .
$$

Przyjęto, podobnie jak w pracy Baxter i Kinga (1993), że funkcja produkcji jest funkcją potęgową o stałych efektach skali względem kapitału prywatnego

${ }^{2} \mathrm{~W}$ modelu transfery stanowią de facto ujemne podatki zryczałtowane. Zatem zarówno z punktu widzenia państwa, jak i gospodarstw domowych istotna jest jedynie różnica pomiędzy zryczałtowanymi podatkami a transferami. 
i nakładu pracy, zależną od łącznej produktywności czynników produkcji oraz poziomu kapitału publicznego, która po zlogarytmowaniu przyjmuje postać:

$\ln y_{t}=z_{t}+\theta \ln k_{t}+\theta_{k G} \ln k_{t}^{G}+(1-\theta) \ln l_{t}$,

gdzie:

$$
\theta, \theta_{k G} \in(0,1)
$$

Zaburzenia stanu równowagi wynikają z szoków fiskalnych dotyczących wydatków rządowych oraz stopy podatkowej:

$$
\begin{aligned}
& g_{t}=\left(1-\rho_{g}\right) \bar{g}+\rho_{g} g_{t-1}+\kappa_{g} \varepsilon_{z, t}+\varepsilon_{g, t}, \varepsilon_{g, t} \sim N\left(0, \sigma_{\varepsilon, g}{ }^{2}\right), \rho_{g} \in(0,1), \bar{g}>0, \\
& \tau_{t}=\left(1-\rho_{\tau}\right) \bar{\tau}+\rho_{\tau} \tau_{t-1}+\kappa_{\tau} \varepsilon_{z, t}+\varepsilon_{\tau, t}, \varepsilon_{\tau, t} \sim N\left(0, \sigma_{\varepsilon, \tau}{ }^{2}\right), \rho_{\tau} \in(0,1), \bar{\tau}>0,
\end{aligned}
$$

a także występujących w standardowym modelu RBC szoków technologicznych, określonych równaniem (5).

Zaburzenia stochastyczne dotyczące polityki fiskalnej oddziałują jednocześnie na bieżące i inwestycyjne wydatki rządowe. Ponadto w modelu zakłada się, że wysokość wydatków rządowych oraz stopy podatkowej może kształtować się pro- lub antycyklicznie. Dla $\kappa_{g}>0$ oraz $\kappa_{\tau}<0$ polityka fiskalna jest procykliczna. Natomiast $\kappa_{g}<0, \kappa_{\tau}>0$ oznacza politykę antycykliczną.

Wydatki rządowe, konsumpcja i inwestycje stanowią składniki agregatowego popytu (por. równanie (50)) oraz zachodzi równanie przyrostu kapitału prywatnego określone równaniem (7), a więc otrzymuje się:

$$
c_{t}=y_{t}+(1-\delta) k_{t}-k_{t+1}-g_{t} \text {. }
$$

Na podstawie przyjętych założeń uzyskuje się, że wewnątrzokresowe równanie podaży pracy oraz równanie Eulera przyjmują postać:

$$
(1-\theta)\left(1-\tau_{t}\right) y_{t}=A\left(c_{t}+\gamma \alpha^{B} g_{t}\right) l_{t}
$$

$\frac{1}{c_{t}+\gamma \alpha^{B} g_{t}}=\beta E_{t}\left(\frac{1}{c_{t+1}+\gamma \alpha^{B} g_{t+1}}\left(\theta \frac{y_{t+1}\left(1-\tau_{t+1}\right)}{k_{t+1}}+1-\delta\right)\right)$.

W rezultacie dynamikę modelu określają równania (5), (192), (194)-(199).

W modelu występuje 18 parametrów. Większość ocen parametrów wyznaczono empirycznie, wykorzystując dane kwartalne dla gospodarki polskiej z lat 1995-20103. Współczynniki autoregresji zmiennych fiskalnych wyznaczone zostały na podstawie estymacji, w oparciu o odsezonowane dane kwartalne z usuniętym trendem. W celu usunięcia trendu zastosowano filtr Christiano i Fitzgeralda (1999). Dane odsezonowano metodą Census $\mathrm{X}-12$. Natomiast wariancje zmiennych

\footnotetext{
${ }^{3}$ Dane Eurostatu, GUS oraz Ministerstwa Finansów.
} 
fiskalnych przyjęto na takim poziomie, by zmienność wydatków rządowych oraz stopy podatkowej zrównać z ich rzeczywistą zmiennością w gospodarce polskiej. Parametry $\bar{g}$ oraz $\bar{\tau}$ wyznaczono zrównując średni udział wydatków rządowych i wpływów podatkowych $\mathrm{w}$ PKB w modelu $\mathrm{z}$ rzeczywistym średnim udziałem wydatków rządowych i wpływów podatkowych w PKB w analizowanym okresie. Parametr $\alpha^{B}$ przyjęto na poziomie równym udziałowi średniemu udziałowi wydatków bieżących w wydatkach publicznych ogółem w badanym okresie.

Współczynnik autoregresji oraz wariancja łącznej produktywności czynników produkcji zostały wyznaczone w oparciu o równanie Solowa na podstawie odsezonowanych z usuniętym trendem, analogicznie jak w przypadku zmiennych fiskalnych ${ }^{4}$.

Elastyczność produkcji względem zatrudnienia oszacowano na poziomie 0,59, na podstawie udziału kosztów pracy w PKB z uwzględnieniem składek na ubezpieczenia społeczne płaconych przez pracodawcę, kosztów pracy osób samozatrudnionych oraz dochodów z pracy w szarej strefie. Wartość elastyczności produkcji względem kapitału obliczono odejmując od jedności elastyczność produkcji względem zatrudnienia. W rezultacie otrzymano elastyczność produkcji względem kapitału na poziomie $0,41^{5}$. Pozostałe parametry przyjęto na podstawie literatury, ze względu na brak możliwości ich precyzyjnego wyznaczenia w oparciu o dane makroekonomiczne. Stopę deprecjacji kapitału przyjęto na poziomie 2,5\% kwartalnie, analogicznie jak w pracy Kydlanda i Prescotta (1982). Elastyczność produkcji względem kapitału publicznego, podobnie jak Hulten i Schwab (1993), założono na poziomie 0,03. Czynnik dyskontujący skalibrowano na standardowym poziomie $0,99 \mathrm{w}$ ujęciu kwartalnym. Natomiast krańcową stopę substytucji konsumpcji prywatnej przyjęto na poziomie 0,23 (por. Aschauer, 1985; Heijdra, Ligthart, 1997). Parametr określający miarę wagi przypisywanej czasowi wolnemu względem konsumpcji obliczono korzystając z równana (9) przedstawionego $\mathrm{w}$ pierwszym rozdziale pracy, przyjmując średni udział czasu pracy równy 1/3, podobnie jak m.in. w opracowaniu Bukowskiego i in. (2005).

W podstawowej wersji modelu założono, że polityka fiskalna, zarówno po stronie dochodowej, jak i wydatkowej, jest acykliczna, czyli $\kappa_{g}, \kappa_{\tau}=0^{6}$.

${ }^{4}$ Średnią wartość łącznej produktywności czynników produkcji znormalizowano do jedności, tj. przyjęto $\bar{z}=0$.

${ }^{5}$ Warto zaznaczyć, że poszczególne oszacowania elastyczności produkcji względem kapitału dla Polski znacząco się różnią, a trudności z jednoznacznym wyznaczeniem tego parametru wynikają m.in. z faktu, że nie ma jednoznacznych miar kosztów pracy (por. Welfe, 2007). W części dynamicznych, stochastycznych modeli równowagi ogólnej dla gospodarki polskiej przyjmuje się niższą elastyczność produkcji względem kapitału. Przykładowo w pracach Bukowskiego i in. (2005), Grabka, Kłosa i Utzig-Lenarczyk (2007) oraz Kolasy (2008) wynosi on ok. 0,3. Z drugiej strony, według oszacowań Kuchty i Piłat (2010) elastyczność produkcji względem kapitału jest wyższa niż elastyczność produkcji względem zatrudnienia.

${ }^{6} \mathrm{~W}$ dalszej części rozdziału poddano analizie skutki uchylenia tych założeń, tj. zbadano oddziaływanie pro- $\mathrm{i}$ antycyklicznego kształtowania się wydatków rządowych oraz stopy podatkowej. 
Na podstawie przedstawionych założeń oraz oszacowań parametrów, w oparciu o oprogramowanie Dynare 4.1.3 (por. np. Barillas i in., 2007; Griffoli, 2007), wygenerowane zostały zmienne symulowane modelu. W celu oceny, w jakim stopniu przyjęty model poprawnie odwzorowuje rzeczywiste zależności pomiędzy zmiennymi, porównano korelacje pomiędzy zmiennymi symulowanymi $\mathrm{z}$ analogicznymi korelacjami między rzeczywistymi zmiennymi dla gospodarki polskiej ${ }^{7}$. Współczynniki korelacji dla zmiennych symulowanych przedstawione są w tabeli 1.

Tabela 1. Współczynniki korelacji zmiennych symulowanych - model uwzględniający szoki fiskalne

\begin{tabular}{|c|c|c|c|c|c|c|c|c|}
\hline Zmienna & $\begin{array}{l}\frac{\pi}{2} \\
\frac{0}{3} \\
\frac{0}{0} \\
0 \\
0\end{array}$ & 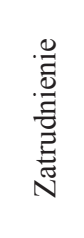 & 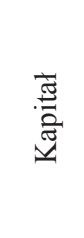 & $\begin{array}{l}\frac{0}{2} \\
\sum_{0}^{0} \\
\vdots \\
\vdots\end{array}$ & 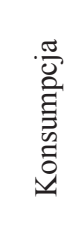 & 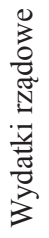 & 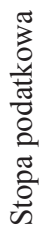 & 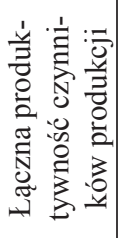 \\
\hline Produkcja & 1 & - & - & - & - & - & - & - \\
\hline Zatrudnienie & 0,92 & 1 & - & - & - & - & - & - \\
\hline Kapitał & 0,40 & 0,10 & 1 & - & - & - & - & - \\
\hline Inwestycje & 0,67 & 0,59 & 0,21 & 1 & - & - & - & - \\
\hline Konsumpcja & 0,44 & 0,13 & 0,99 & 0,10 & 1 & - & - & - \\
\hline Wydatki rządowe & 0,07 & 0,09 & $-0,13$ & $-0,38$ & $-0,17$ & 1 & - & - \\
\hline Stopa podatkowa & $-0,84$ & $-0,95$ & $-0,21$ & $-0,39$ & $-0,21$ & 0 & 1 & - \\
\hline $\begin{array}{l}\text { Łączna produktyw- } \\
\text { ność czynników } \\
\text { produkcji }\end{array}$ & 0,52 & 0,27 & 0,23 & 0,77 & 0,31 & 0 & 0 & 1 \\
\hline
\end{tabular}

Źródło: opracowanie własne na podstawie danych Eurostatu, GUS i Ministerstwa Finansów.

Zarówno w przypadku danych rzeczywistych, jak i symulowanych produkcja jest najsilniej dodatnio skorelowana $\mathrm{z}$ zatrudnieniem, inwestycjami oraz łączną produktywnością czynników produkcji, a najsłabiej z wydatkami rządowymi i kapitałem. Warto też dodać, że zarówno w przypadku danych rzeczywistych, jak i symulowanych występuje ujemna korelacja pomiędzy stopą podatkową a produkcją.

W modelu występuje bardzo silna korelacja dodatnia pomiędzy konsumpcją a ilością kapitału, która nie ma odzwierciedlenia w danych rzeczywistych. Bliski jedności współczynnik korelacji pomiędzy ilością kapitału a konsumpcją wynika z faktu, że w modelu zarówno szoki technologiczne, jak i szoki fiskalne wywierają jednokierunkowy wpływ na kapitał oraz konsumpcję. Dodatni szok

${ }^{7}$ Z usuniętym trendem (szerzej na ten temat por. Kuchta, Piłat, 2010). 
technologiczny podwyższa ilość kapitału oraz zwiększa konsumpcję, natomiast wzrost wydatków rządowych lub stopy podatkowej obniża obie te zmienne.

Na podstawie zmiennych symulowanych uzyskano, że wydatki rządowe są dodatnio skorelowane jedynie z produkcją i wielkością zatrudnienia. W szczególności model generuje ujemną korelację, niemającą potwierdzenia w danych rzeczywistych, pomiędzy wydatkami rządowymi a wielkością konsumpcji. Wynika to z faktu, że w modelu wpływ wydatków rządowych na zachowanie gospodarstw domowych odbywa się głównie poprzez efekt majątkowy. Wzrost wydatków rządowych powoduje negatywny efekt majątkowy, a w rezultacie ograniczenie konsumpcji. Na występowanie w modelu ujemnej zależności pomiędzy konsumpcją a wydatkami rządowymi wpływa również fakt, że konsumpcja publiczna stanowi w modelu dobro substytucyjne względem konsumpcji prywatnej. W rezultacie wzrost wydatków rządowych dodatkowo ogranicza wysokość konsumpcji prywatnej.

$\mathrm{Z}$ porównania analizowanego modelu z modelem Hansena nieuwzględniającym polityki fiskalnej, opracowanym przez Kuchtę i Piłat (2010), wynika, że rozszerzenie modelu o politykę fiskalną zmniejsza korelacje pomiędzy łączną produktywnością czynników produkcji a pozostałymi zmiennymi, przybliżając je do wielkości występujących w polskiej gospodarce (por. tab. 2). Ponadto wprowadzenie do modelu wydatków rządowych i podatków znacznie zmniejsza korelację pomiędzy konsumpcją prywatną a produkcją. W rezultacie, o ile w modelu Kuchty i Piłat uzyskano współczynnik korelacji między tymi zmiennymi wyższy niż dla danych rzeczywistych, o tyle w modelu uwzględniającym politykę fiskalną jest on niedoszacowany.

Tabela 2. Współczynniki korelacji zmiennych symulowanych - model nie uwzględniający polityki fiskalnej

\begin{tabular}{|c|c|c|c|c|c|}
\hline Zmienna & 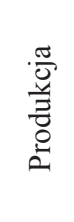 & 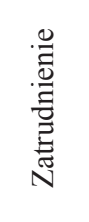 & 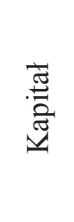 & 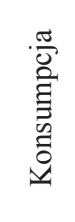 & 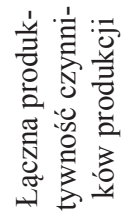 \\
\hline Produkcja & 1 & - & - & - & - \\
\hline Zatrudnienie & 0,98 & 1 & - & - & - \\
\hline Kapitał & 0,36 & 0,17 & 1 & - & - \\
\hline Konsumpcja & 0,66 & 0,50 & 0,94 & 1 & - \\
\hline $\begin{array}{l}\text { Łączna produktywność czynników } \\
\text { produkcji }\end{array}$ & 1,00 & 0,97 & 0,40 & 0,69 & 1 \\
\hline
\end{tabular}

Źródło: Kuchta, Piłat (2010). 
W modelu występują trzy źródła szoków: zmiany w wydatkach rządowych, zmiany stopy podatkowej oraz szoki technologiczne. Podażowe efekty szoków fiskalnych przedstawiono w dalszej części rozdziału, w oparciu o funkcje reakcji na impuls, uwzględniające wszystkie równoczesne oraz opóźnione zależności pomiędzy zmiennymi modelu (por. np. Grabek, Kłos, Koloch, 2010). Natomiast wpływ dodatniego szoku technologicznego jest analogiczny jak w standardowym modelu RBC - wzrost łącznej produktywności czynników produkcji zwiększa zarówno poziom zatrudnienia, kapitału, produkcji, jak i konsumpcji ${ }^{8}$.

\subsection{Podażowe efekty zwiększenia wydatków rządowych}

W pierwszej kolejności poddano analizie efekty szoku fiskalnego polegającego na zwiększeniu wydatków rządowych, sfinansowanym wyższymi podatkami zryczałtowanymi (niezależnymi od dochodu). Zgodnie z ekwiwalencją ricardiańską, rozkład w czasie podatków niezależnych od dochodu (lub deficytu budżetowego) nie wpływa na decyzje gospodarstw domowych, zatem przedstawiona analiza umożliwia wyodrębnienie podażowych skutków przejściowych zmian wydatków rządowych ${ }^{9}$. Na rysunku 1 przedstawiono oddziaływanie szoku fiskalnego, polegającego na trwającym 1 rok podwyższeniu wydatków rządowych o 1\% PKB, na kształtowanie się poszczególnych zmiennych w modelu (jeden okres oznacza kwartał ${ }^{10}$. Na podstawie obserwacji powojennych wahań aktywności gospodarczej prowadzonych przez National Bureau of Economics Research (NBER) długość trwania cyklu koniunkturalnego określa się na okres od około sześciu do trzydziestu dwóch kwartałów (por. Baxter i King, 1995; Christiano, Fitzgerald, 1999). Z tego względu w pracy, w oparciu o funkcje reakcji na impuls, analizowane jest oddziaływanie polityki fiskalnej na gospodarkę obejmujące 32 kwartały.

${ }^{8}$ Wynikające z modelu wnioski dotyczące podażowych efektów zmian łącznej produktywności czynników produkcji są zbliżone do wniosków przedstawionych w pracy Kuchty i Piłat (2010). Szczegółowy opis oddziaływania szoku technologicznego przedstawiony jest w przywołanej pracy.

${ }^{9} \mathrm{~W}$ dalszej części rozdziału poddano również analizie podażowe efekty podniesienia wydatków rządowych sfinansowanego wyższą stopą podatkową, gdzie na końcowy efekt szoku fiskalnego składa się oddziaływanie na decyzje gospodarstw domowych zarówno zmian wydatków rządowych, jak i stopy opodatkowania.

${ }^{10}$ Funkcje reakcji na impuls ukazują często skutki zaburzenia danej zmiennej o wysokość odchylenia standardowego, która następnie wygasa zgodnie z założonym procesem autoregresyjnym. W pracy analizowane są skutki zwiększenia wydatków rządowych o 1\% PKB (lub w przypadku stóp podatkowych - o 1 pkt proc.), które po okresie jednego roku wracają do poziomu sprzed wystąpienia zaburzenia, ze względu na większą możliwość interpretacji ekonomicznej tak zdefiniowanych szoków fiskalnych. 

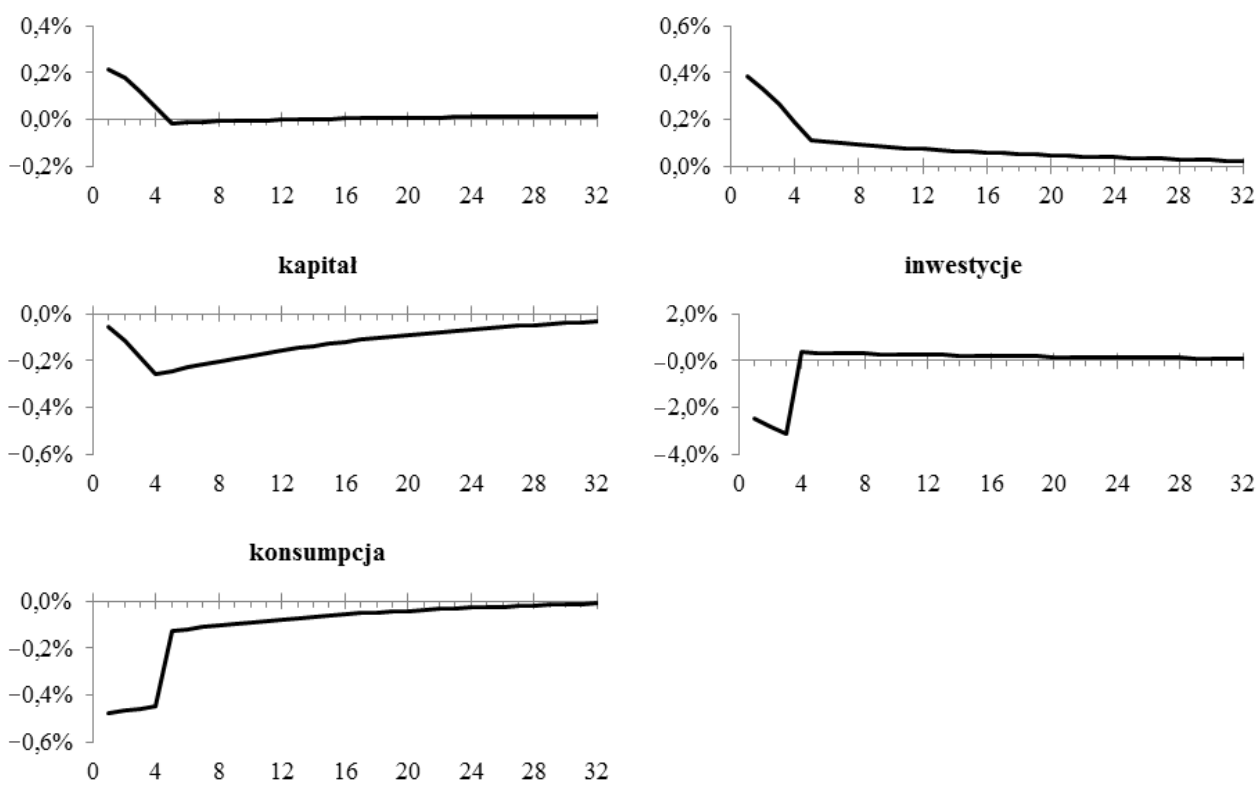

Rysunek 1. Oddziaływanie przejściowego, trwającego jeden rok, zwiększenia wydatków rządowych o $1 \%$ PKB na procentowe odchylenie poszczególnych zmiennych od poziomu bazowego (dane kwartalne)

Źródło: opracowanie własne na podstawie danych Eurostatu, GUS i Ministerstwa Finansów.

Z przeprowadzonych symulacji wynika, że w pierwszym kwartale po wystąpieniu szoku fiskalnego produkcja ulega zwiększeniu o $0,2 \%$. Otrzymany na podstawie modelu RBC mnożnik fiskalny jest więc zdecydowanie niższy od jedności.

Uzyskane mnożniki fiskalne porównano z oszacowaniami krótkookresowego, podażowego wpływu wydatków rządowych, otrzymanymi na podstawie innych modeli $\mathrm{RBC}^{11}$. W ramach analizy oddziaływania polityki fiskalnej na gospodarkę polską oszacowania wynikające z modelu RBC przedstawiają Bukowski i in. (2005). W omawianym przez nich modelu parametry są przyjęte, odmiennie niż w niniejszym rozdziale, na analogicznym poziomie, jak w modelach dla gospodarki amerykańskiej oraz strefy euro. $Z$ analiz Bukowskiego i in. wynika,

${ }^{11}$ W tym rozdziale dokonano porównania wyników z innymi obliczeniami dotyczącymi krótkookresowych, podażowych skutków zmian wydatków rządowych, tj. szacunkami wykonanymi na podstawie modeli realnego cyklu koniunkturalnego. Przegląd oszacowań mnożników fiskalnych wyznaczonych na podstawie modeli uwzględniających efekty popytowe ukazano w następnym rozdziale. 
że w przypadku, gdy okres półtrwania szoku wynosi cztery kwartały, wówczas finansowane spadkiem zryczałtowanych transferów podwyższenie konsumpcji publicznej o 1\% PKB zwiększa w początkowym okresie produkcję o ok. $0,15 \%{ }^{12}$. Zarazem, jak wskazują Bukowski i in., wydłużenie trwania szoku fiskalnego zwiększa jego siłę oddziaływania na gospodarkę. Zgodnie z oszacowaniami autorów, jeśli okresu półtrwania szoku wynosi 16 kwartałów, wówczas w pierwszym roku produkcja ulega zwiększeniu o prawie $0,4 \%$ PKB.

Zestawiając otrzymane wyniki z rezultatami uzyskanymi przez Baxter i Kinga (1993) zaobserwować można, że podażowy wpływ zwiększenia wydatków rządowych jest w gospodarce polskiej relatywnie słabszy niż w gospodarce amerykańskiej. Zgodnie z szacunkami Baxter i Kinga, w przypadku trwającego cztery lata podwyższenia poziomu wydatków rządowych o $1 \%$ PKB produkcja w pierwszym roku rośnie o $0,6 \%$, a następnie stopniowo zbiega do poziomu sprzed wystąpienia szoku fiskalnego. Wyższy wzrost PKB wynika częściowo $\mathrm{z}$ dłuższego niż $\mathrm{w}$ analizowanym modelu dla gospodarki polskiej, założonego okresu trwania szoku fiskalnego. Warto przy tym zaznaczyć, że nowsze badanie, które na podstawie modelu RBC dla gospodarki amerykańskiej przeprowadziła Pappa (2004), wskazują, że w gospodarce amerykańskiej przejściowe zwiększenie wydatków rządowych skutkuje krótkotrwałym zwiększeniem produkcji o nie więcej niż $0,2 \%$. Natomiast Totzek i Winkler (2010) otrzymali na podstawie modelu RBC dla gospodarki amerykańskiej, że przejściowe zwiększenie wydatków rządowych o $1 \%$ PKB wpływa na przejściowe zwiększenie produkcji o $0,44 \%$.

W zastosowanym w niniejszym rozdziale modelu wzrost wydatków rządowych wpływa na PKB poprzez dwa wzmacniające się efekty. Po pierwsze, negatywny efekt majątkowy powoduje zmniejszenie czasu wolnego oraz zwiększenie zatrudnienia. Po drugie, wynikający z wyższych inwestycyjnych wydatków rządowych wzrost kapitału publicznego zgodnie z funkcją produkcji oddziałuje na możliwości wytwórcze.

Negatywny efekt majątkowy wpływa zarówno na zmniejszenie ilości czasu wolnego, jak i konsumpcji. Na podstawie symulacji otrzymuje się również, że na skutek podwyższenia wydatków rządowych w początkowym okresie następuje znaczny spadek inwestycji. Niższy poziom inwestycji ma na celu wygładzenie wahań konsumpcji - następuje przesunięcie środków z inwestycji na konsumpcję, tak by nie doprowadzić do gwałtownych wahań konsumpcji w przejściowym okresie drenażu zasobów z gospodarki. Gdy wydatki rządowe wracają do poziomu sprzed szoku następuje nieznaczny wzrost inwestycji, mający na celu odbudowanie ilości kapitału prywatnego. $Z$ jednej strony zatem wyższe zatrudnienie wpływa na wzrost PKB, a z drugiej strony ograniczenie ilości kapitału

\footnotetext{
${ }^{12}$ Jak wspomniano wcześniej, zmniejszenie zryczałtowanych transferów powoduje analogiczne skutki jak podniesienie zryczałtowanych podatków.
} 
obniża wartość produkcji. Początkowo wzrost produkcji wynikający z wyższego poziomu zatrudnienia jest znacznie silniejszy niż ograniczenie produkcji na skutek niższego poziomu kapitału. Jednak wraz z obniżaniem się zatrudnienia do poziomu wyjściowego produkcja ulega ograniczeniu. W rezultacie oddziaływanie szoku fiskalnego na poziom PKB szybko wygasa. Po ustąpieniu szoku fiskalnego (tj. po 4 kwartałach) utrzymywanie się produkcji powyżej poziomu wyjściowego wynika przede wszystkim z wyższego poziomu kapitału publicznego. W analizowanym modelu wydatki rządowe oddziałują bowiem na PKB nie tylko poprzez efekt majątkowy, ale i poprzez wpływ na kształtowanie się kapitału publicznego. Inwestycyjne wydatki rządowe w okresie trwania szoku zwiększają zasób kapitału publicznego, który w kolejnych latach zgodnie z funkcją określoną równaniem (194) powoduje wzrost produkcji.

Na skutek przejściowej zmiany wydatków rządowych w okresie szoku zmianie ulegają również ceny czynników produkcji. Stawka płac ulega obniżeniu, natomiast stopa procentowa wzrasta. W okresie dostosowywania się gospodarki po szoku, stawka płac oraz stopa procentowa stopniowo powracają do wyjściowego poziomu.

Na podstawie modelu otrzymuje się ujemną zależność pomiędzy wydatkami rządowymi i konsumpcją. Wynika ona zarówno z substytucyjności wydatków rządowych i konsumpcji prywatnej, jak i z faktu, że wyższe wydatki rządowe powodują negatywny efekt majątkowy. Pierwszy z wymienionych efektów występuje jedynie $\mathrm{w}$ okresie występowania szoku, czyli przez pierwsze 4 kwartały. Natomiast obniżenie się konsumpcji prywatnej, będące następstwem drenażu przez wydatki rządowe zasobów z gospodarki, ma charakter bardziej długotrwały, ponieważ gospodarstwa domowe starają się ograniczyć wahania konsumpcji i rozkładają w czasie skutki negatywnego efektu majątkowego.

Jak wskazano powyżej, jedną z przyczyn występowania w modelu ujemnej korelacji pomiędzy tymi zmiennymi jest przyjęcie założenia, że konsumpcja prywatna i publiczna są dobrami substytucyjnymi. Choć założenie to jest często przyjmowane w literaturze (por. np. Aschauer 1988; Christiano i Eichenbaum, 1992; Amano, Wirjanto, 1997), to brak jest w Polsce badań empirycznych określających poziom substytucyjności pomiędzy konsumpcją prywatną a publiczną. Warto przy tym zaznaczyć, że jeżeli konsumpcja prywatna i publiczna nie są dobrami substytucyjnymi, wówczas wpływ wzrostu wydatków rządowych na kształtowanie się produkcji jest silniejszy ${ }^{13}$. Wynika to $\mathrm{z}$ faktu, że w tym przypadku negatywny efekt majątkowy silniej oddziałuje na gospodarstwa domowe. Wyższe wydatki rządowe zmniejszają bowiem dostępną ilość zasobów w gospodarce, nie wpływając na podniesienie poziomu użyteczności osiąganego przez gospodarstwa domowe. W rezultacie, w większym stopniu niż w przypadku występowania substytucyjności pomiędzy konsumpcją prywatną a publiczną, zmniejszeniu ulega czas

${ }^{13} \mathrm{Z}$ wykonanych symulacji wynika, że dla $\gamma=0$ mnożnik wydatków rządowych wynosi $0,3 \%$. 
wolny, a zwiększeniu - zatrudnienie. Relatywnie słabiej na szok fiskalny reaguje natomiast konsumpcja prywatna. Wyższa konsumpcja publiczna nie stanowi bowiem w tym przypadku substytutu względem niższej konsumpcji gospodarstw domowych, które nie chcąc doprowadzić do dużych wahań użyteczności jedynie w ograniczonym zakresie ograniczają poziom konsumpcji.

Na wydatki rządowe składają się zarówno wydatki bieżące, jak i inwestycyjne. Mechanizm oddziaływania każdej z tych kategorii budżetowych jest odmienny. Wydatki bieżące oddziałują poprzez efekt majątkowy, natomiast wydatki inwestycyjne - głównie poprzez funkcję produkcji. W dyskursie na temat reformy finansów publicznych często wskazuje się, że z punktu widzenia oddziaływania polityki fiskalnej na gospodarkę korzystne jest zwiększanie udziału wydatków majątkowych. Na rysunku 2 przedstawione zostały podażowe skutki przejściowego, trwającego jeden rok, podniesienia o 1 punkt proc. udziału majątkowych wydatków rządowych w wydatkach rządowych ogółem.
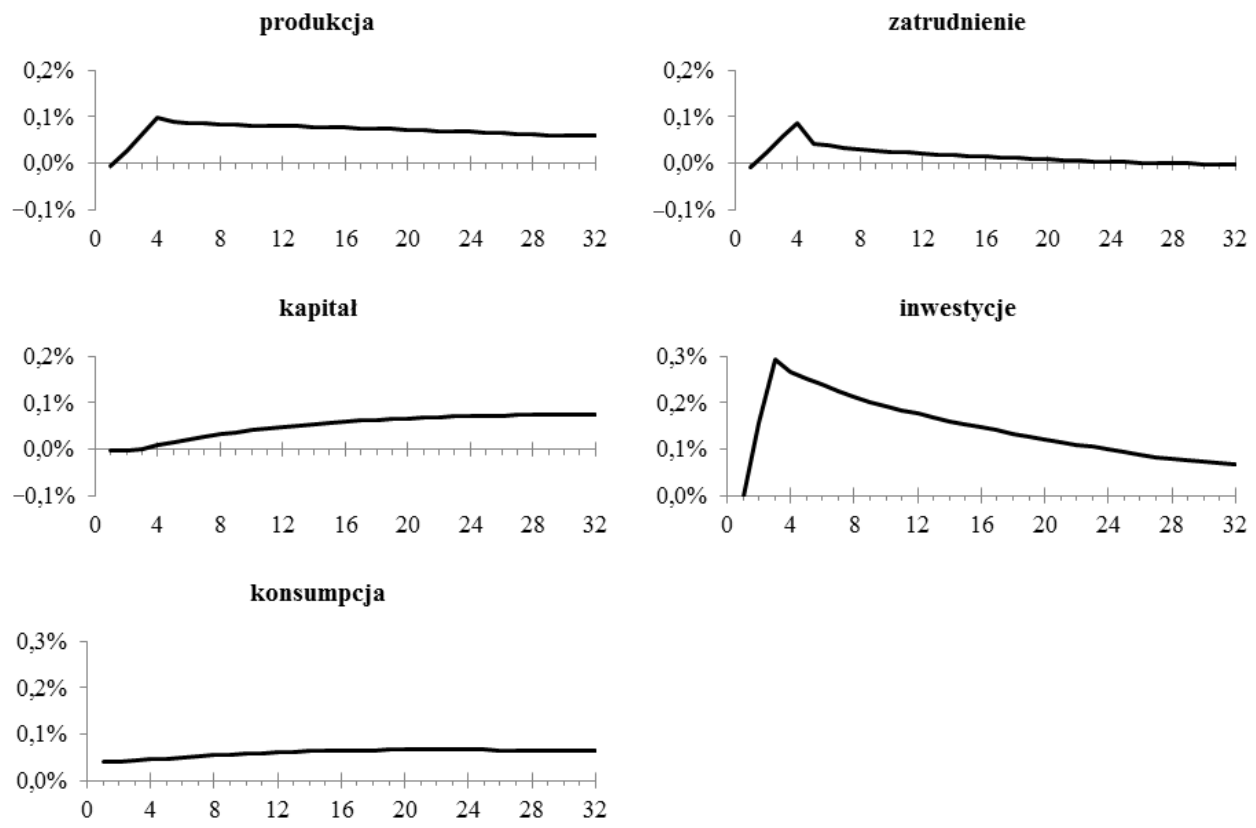

Rysunek 2. Wpływ przejściowego, trwającego jeden rok, zwiększenia o 1 pkt proc. udziału majątkowych wydatków publicznych w wydatkach rządowych ogółem na procentowe odchylenie poszczególnych zmiennych od poziomu bazowego (dane kwartalne)

Źródło: opracowanie własne na podstawie danych Eurostatu, GUS i Ministerstwa Finansów.

Z przeprowadzonych symulacji wynika, że zastąpienie części bieżących wydatków rządowych wydatkami majątkowym prowadzi do wzrostu produkcji. 
Podniesienie wydatków majątkowych oddziałuje na podwyższenie poziomu kapitału publicznego, który z kolei wpływa na kształtowanie się PKB w sposób analogiczny jak łączna produktywność czynników produkcji. Następuje zatem zwiększenie poziomu konsumpcji, kapitału oraz zatrudnienia. Wynikający ze zwiększenia wydatków majątkowych wzrost konsumpcji i kapitału jest ponadto wzmocniony przez działanie pozytywnego efektu majątkowego wynikającego ze zmniejszenia bieżących wydatków rządowych.

Następstwa podwyższenia udziału wydatków majątkowych są relatywnie trwałe, ponieważ zwiększony kapitał publiczny przez wiele okresów oddziałuje na funkcję produkcji, zbiegając do wyjściowego poziomu bardzo powoli, jedynie na skutek deprecjacji. W rezultacie skutki przejściowego zwiększenia wydatków majątkowych są trwalsze niż skutki przejściowych szoków technologicznych, które stopniowo wygasają (por. Kuchta, Piłat, 2010) ${ }^{14}$. Z modelu wynika zatem, że zwiększenie $w$ wydatkach rządowych udziału publicznych wydatków majątkowych wywiera pozytywny wpływ na gospodarkę. W sposób relatywnie trwały podwyższa produkcję, konsumpcję, zatrudnienie i poziom kapitału, zarówno publicznego, jak i prywatnego. Zbliżone rezultaty otrzymano dla gospodarki amerykańskiej - zgodnie z oszacowaniami Baxter i Kinga (1993) zwiększenie publicznych wydatków majątkowych silnie oddziałuje na wzrost kapitału, zatrudnienia oraz produkcji.

Do tej pory zakładano, że wydatki rządowe kształtują się w sposób acykliczny. Jednocześnie antycykliczne kształtowanie się wydatków budżetowych jest wskazywane jako jeden z mechanizmów oddziaływania państwa na ograniczenie fluktuacji gospodarczych (por. np. Giorno, Richardson, Roseveare, van den Noord, 1995; Brandner, Diebalek, Schuberth, 1998; Brunila, Buti, in't Veld, 2002). $Z$ tego względu analizie poddany został wpływ procyklicznego i antycyklicznego kształtowania się wydatków rządowych na podażowe oddziaływanie polityki fiskalnej.

Kształtowanie się wydatków rządowych w ramach cyklu określa równanie (195). W przypadku, gdy $\kappa_{g}>0$, państwo prowadzi politykę procykliczną, natomiast dla $\kappa_{g}<0$, występuje polityka antycykliczna. W tabeli 3 ukazany został wpływ cykliczności prowadzonej polityki fiskalnej na wielkość fluktuacji zmiennych symulowanych. Dla polityki fiskalnej antycyklicznej przyjęto $\kappa_{g}=-5$, natomiast dla procyklicznej $\kappa_{g}=5$.

${ }^{14}$ Warto przy tym zaznaczyć, że w pracy Kuchty i Piłat (2010) analizowany jest szok technologiczny, który utrzymuje się przez wiele okresów (zgodnie z założonym procesem autoregresyjnym), co wpływa na relatywnie trwalsze jego skutki. Natomiast analizowane w niniejszym rozdziale szoki fiskalne trwają jedynie jeden rok. Mimo innego zdefiniowania szoków, porównanie symulacji Kuchty i Piłat dotyczących następstw szoku technologicznego z wynikami przedstawionymi na rysunku 2 wskazuje, że po 8 latach od wystąpienia zaburzeń efekty szoku fiskalnego są większe. 
Tabela 3. Odchylenia standardowe zmiennych symulowanych w przypadku prowadzenia procyklicznej i antycyklicznej polityki fiskalnej dotyczącej wydatków rządowych

\begin{tabular}{|l|c|c|}
\hline \multirow{2}{*}{\multicolumn{1}{|c|}{ Zmienna }} & \multicolumn{2}{|c|}{$\begin{array}{c}\text { Odchylenie standardowe zmiennej w relacji do jej odchylenia } \\
\text { standardowego w przypadku prowadzenia polityki acyklicznej }\end{array}$} \\
\cline { 2 - 3 } & polityka procykliczna & polityka antycykliczna \\
\hline Produkcja & 1,051 & 0,964 \\
\hline Zatrudnienie & 1,021 & 0,983 \\
\hline Kapitał & 0,789 & 1,496 \\
\hline Inwestycje & 0,702 & 1,571 \\
\hline Konsumpcja & 0,771 & 1,484 \\
\hline Wydatki rządowe & 1,944 & 1,944 \\
\hline Stopa podatkowa & 1,000 & 1,000 \\
\hline $\begin{array}{l}\text { Łączna produktywność } \\
\text { czynników produkcji }\end{array}$ & 1,000 & 1,000 \\
\hline
\end{tabular}

Źródło: opracowanie własne na podstawie danych Eurostatu, GUS i Ministerstwa Finansów.

W przypadku antycyklicznej polityki fiskalnej reakcja produkcji na szok technologiczny jest nieznacznie słabsza, niż w sytuacji, gdy wydatki rządowe mają charakter procykliczny. Jednocześnie na podstawie analizowanego modelu podażowego otrzymuje się, że w przypadku antycyklicznej polityki fiskalnej w reakcji na szok technologiczny następują większe zmiany w poziomie konsumpcji, inwestycji oraz kapitału. Wynika to z faktu, że wraz ze spadkiem PKB następuje wzrost wydatków rządowych, który poprzez negatywny efekt majątkowy prowadzi co prawda do ograniczenia spadku produkcji, ale jednocześnie powoduje obniżenie się ilości kapitału i konsumpcji. W rezultacie efekty podażowe antycyklicznej polityki fiskalnej wpływają na pogłębienie się wahań kapitału i konsumpcji będących następstwem szoków technologicznych. Zatem na podstawie analizy efektów podażowych otrzymuje się, że antycykliczna polityka fiskalna nie jest skutecznym narzędziem niwelowania wynikających z fluktuacji gospodarczych wahań konsumpcji prywatnej. Z modelu wynika jednocześnie, że antycykliczna polityka fiskalna prowadzi do zmniejszenia się wahań zatrudnienia. W przypadku tak prowadzonej polityki fiskalnej następujący na skutek pozytywnego szoku technologicznego wzrost zatrudnienia jest częściowo niwelowany przez towarzyszący spadkowi wydatków rządowych pozytywny efekt majątkowy. Pozytywny efekt majątkowy prowadzi bowiem do zwiększenia czasu wolnego i spadku zatrudnienia. W rezultacie antycykliczna polityka fiskalna, poprzez efekt majątkowy, może doprowadzić nawet do sytuacji, w której pozytywny szok technologiczny skutkować będzie nie wzrostem, lecz spadkiem zatrudnienia.

Charakter podażowego oddziaływania wydatków rządowych zależy od tego, czy dany wydatek ma charakter bieżący, czy też majątkowy. Ponadto w przypadku 
wydatków bieżących wpływ polityki fiskalnej na konsumpcję uzależniony jest od substytucyjności danego wydatku względem konsumpcji prywatnej. W celu identyfikacji podażowego oddziaływania poszczególnych kategorii wydatkowych przyjęto, że osobne szoki fiskalne, analogiczne jak w przypadku równania (195), występują dla:

- bieżących wydatków rządowych doskonale substytucyjnych względem konsumpcji prywatnej,

- bieżących wydatków rządowych niebędących substytutami względem konsumpcji prywatnej,

- inwestycyjnych wydatków rządowych.

Gospodarstwa domowe w analizowanej wersji modelu maksymalizują wartość oczekiwaną sumy zdyskontowanych użyteczności postaci:

$$
U=E\left(\sum_{t=0}^{\infty} \beta^{t}\left(\ln \left(c_{t}+g_{t}^{S}\right)+A h_{t}\right)\right)
$$

gdzie:

$g_{t}^{S}-$ wydatki bieżące doskonale substytucyjne względem konsumpcji prywatnej ${ }^{15}$.

Z przeprowadzonych symulacji wynika, że wzrost wydatków inwestycyjnych (majątkowych) wywiera na pozostałe zmienne wpływ zbliżony do oddziaływania pozytywnego szoku technologicznego. Wyższe wydatki majątkowe podwyższają zarówno poziom zatrudnienia, kapitału, produkcji, jak i konsumpcji. Oddziaływanie na produkcję jest $\mathrm{w}$ tym przypadku relatywnie trwałe $\mathrm{z}$ następujących, wzmacniających się powodów. Po pierwsze, wyższy poziom wydatków majątkowych przekłada się na wieloletnie utrzymywanie się kapitału publicznego powyżej poziomu wyjściowego. Po drugie, szok fiskalny dotyczący poziomu wydatków majątkowych wygasa stopniowo, przez kilka okresów podwyższając poziom kapitału publicznego. W rezultacie jeszcze po ośmiu latach od momentu wystąpienia szoku poziom produkcji utrzymuje się na poziomie istotnie wyższym od poziomu wyjściowego.

Zwiększenie bieżących wydatków rządowych niebędących substytutami konsumpcji prywatnej wywiera natomiast jedynie przejściowy wpływ na produkcję. Po okresie szoku, tj. po czterech kwartałach, produkcja wraca do poziomu wyjściowego. Jednocześnie poziom konsumpcji przez dłuższy czas utrzymuje się poniżej poziomu wyjściowego. Zatem wzrost bieżących wydatków rządowych nie będących substytutami konsumpcji prywatnej powoduje relatywnie trwałe obniżenie konsumpcji i jedynie krótkotrwały wzrost PKB. Ponadto na skutek negatywnego efektu majątkowego następuje wzrost zatrudnienia i obniżenie poziomu kapitału. Wydatki rządowe będące doskonałymi substytutami konsumpcji prywatnej oddziałują z kolei

\footnotetext{
${ }^{15}$ Założono, że wydatki substytucyjne względem konsumpcji prywatnej połowę bieżących wydatków rządowych. Udział w wydatkach rządowych wydatków substytucyjnych względem konsumpcji prywatnej nie wpływa przy tym w istotny sposób na otrzymane funkcje reakcji na impuls.
} 
jedynie na konsumpcję prywatną. Podwyższenie tej kategorii wydatków rządowych powoduje analogiczne obniżenie konsumpcji prywatnej i w rezultacie nie oddziałuje na poziom użyteczności gospodarstw domowych oraz ich decyzje dotyczące czasu pracy i ilości kapitału. Zmiany tej kategorii wydatków nie wpływają zatem na wysokość produkcji, zatrudnienia czy kapitału.

$\mathrm{Z}$ modelu wynika więc, że bieżące wydatki rządowe nie oddziałują na kształtowanie się produkcji w dłuższym okresie. Co więcej, zmiany bieżących wydatków rządowych będących doskonałymi substytutami konsumpcji prywatnej nie powodują nawet krótkookresowych zmian PKB.

\subsection{Skutki zmian stóp podatkowych}

Zmiany stóp podatkowych stanowią drugi, obok zmian wydatków rządowych, mechanizm oddziaływania polityki fiskalnej na gospodarkę. Rysunek 3 przedstawia funkcje reakcji na szok w polityce fiskalnej, polegający na przejściowym zwiększeniu stopy podatkowej.
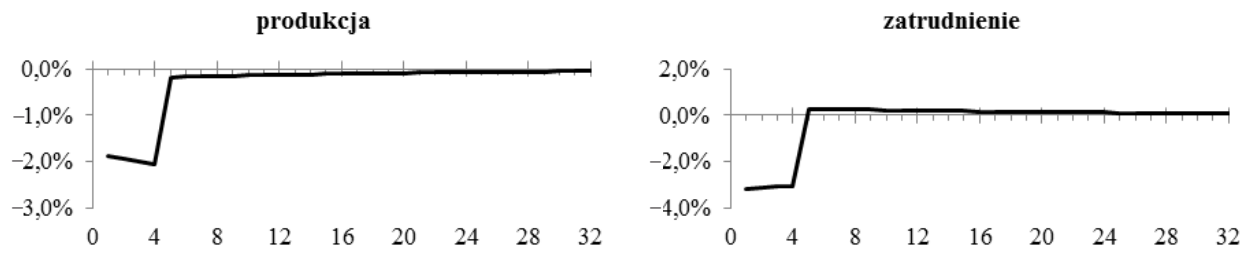

kapital

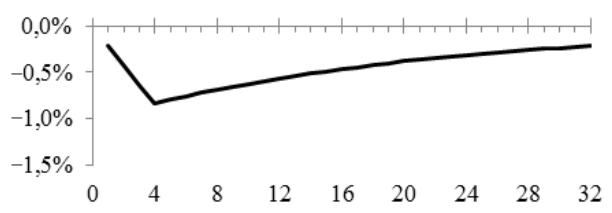

inwestycje

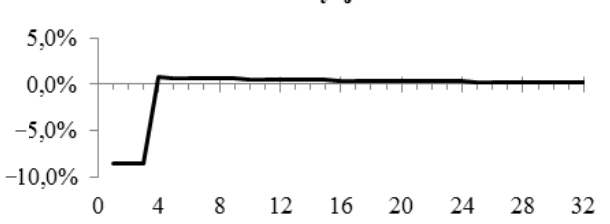

konsumpcja

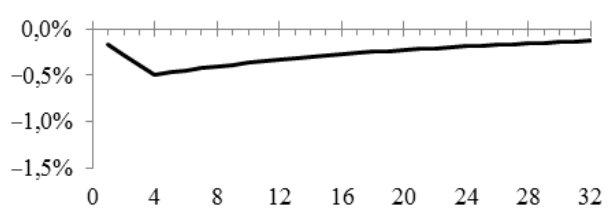

Rysunek 3. Oddziaływanie przejściowego, trwającego jeden rok, wzrostu stopy opodatkowania dochodów o $1 \mathrm{pkt}$ proc. na procentowe odchylenie zmiennych od poziomu bazowego (dane kwartalne)

Źródło: opracowanie własne na podstawie danych Eurostatu, GUS i Ministerstwa Finansów. 
Wzrost stopy podatkowej prowadzi do obniżenia się krańcowego produktu kapitału oraz krańcowego produktu pracy po opodatkowaniu. Zmniejsza się poziom kapitału i zatrudnienia, a w efekcie ograniczeniu ulega także wysokość produkcji. Czynnikiem produkcji silniej reagującym na szok fiskalny jest zatrudnienie, które jednak wraca do poziomu wyjściowego relatywnie szybko. Natomiast negatywny wpływ wyższego opodatkowania na kształtowanie się ilości kapitału jest co prawda słabszy, ale równocześnie bardziej długotrwały.

Kapitał ulega obniżeniu zarówno ze względu na fakt, że zmniejszeniu ulega krańcowy produkt kapitału, jak i w wyniku tego, że część kapitału zostaje zastąpiona konsumpcją, tak by nie dopuścić do nadmiernych wahań konsumpcji gospodarstw domowych. Dostosowania w poziomie kapitału prowadzą do bardzo silnych zmian inwestycji - w następstwie szoku fiskalnego inwestycje ulegają przejściowemu obniżeniu o ok. $8 \%$. W rezultacie zwiększenie stopy opodatkowania o 1 pkt proc. powoduje znaczne ograniczenie PKB. W czasie występowania szoku produkcja ulega zmniejszeniu o ok. 2\%. Natomiast w następnych latach kształtuje się na poziomie o $0,1-0,2 \%$ niższym od poziomu wyjściowego. Zatem z modelu wynika, że zacieśnienie polityki fiskalnej po stronie dochodowej wywiera silniejszy negatywny wpływ PKB niż ograniczenie wydatków rządowych ${ }^{16}$. Wyższe opodatkowanie $\mathrm{w}$ większym stopniu negatywnie oddziałuje przy tym na obydwa czynniki produkcji - zarówno zatrudnienie, jak i ilość kapitału.

Otrzymane wyniki, zgodnie z którymi zwiększenie stóp podatkowych wywiera silny wpływ na produkcję, są zbieżne z rezultatami, które uzyskali Ludvigson (1996) oraz Fatas i Mihov (2001) dla gospodarki amerykańskiej (por. też Alesina i Ardagna, 2010). Jednocześnie wskazują one na znacznie silniejsze negatywne podażowe oddziaływanie zwiększenia opodatkowania niż wynika to z modelu RBC przedstawionego przez Bukowskiego i in. (2005). Autorzy ci uzyskali, że przejściowy wzrost opodatkowania o $1 \% \mathrm{PKB}^{17}$ powoduje przejściowe ograniczenie produkcji o mniej niż $1 \%{ }^{18}$. Różnice w otrzymanych efektach podażowych wzrostu stóp podatkowych wynikać mogą m.in. z innych założeń dotyczących funkcji użyteczności, a także z innych wartości parametrów. Przykładowo, w analizowanym w niniejszym rozdziale pracy modelu na podstawie danych dla gospodarki polskiej oszacowano elastyczność

${ }^{16}$ Przy czym podniesienie stopy podatkowej o 1 pkt proc. przekłada się na wzrost dochodów publicznych o mniej niż $1 \%$ PKB, ze względu na negatywne oddziaływanie wyższej stopy podatkowej na produkcję i w rezultacie zmniejszenie się bazy podatkowej. Podażowe oddziaływanie na gospodarkę przejściowego wzrostu wydatków rządowych sfinansowanego wyższymi o $1 \%$ PKB podatkami nakładanymi na dochody przedstawiono w dalszej części rozdziału.

${ }^{17}$ Zatem analizowane w pracy Bukowskiego i in. (2005) zwiększenie stopy podatkowej jest wyższe niż 1 pkt proc., ze względu na zmniejszenie się bazy podatkowej.

${ }^{18}$ Według Bukowskiego i in. (2005) w zależności od rodzaju opodatkowania i trwania szoku spadek produkcji wynosi od $0,1 \%$ do $0,8 \%$. Warto zaznaczyć, że na relatywnie słaby wpływ podatków na kształtowanie się agregatowej podaży wskazują również oszacowania ekonometryczne Milo i in. (1999). 
produkcji względem kapitału na poziomie 0,41, podczas gdy Bukowski i in. przyjęli tę elastyczność równą 0,3 . Ponadto inna jest specyfikacja wydatków inwestycyjnych. W analizowanym $\mathrm{w}$ niniejszym rozdziale modelu publiczne wydatki inwestycyjne stanowią stałą część wydatków rządowych, natomiast Bukowski i in. przyjmują, że stanowią one stałą część PKB.

Reakcje na impuls przedstawione na rysunku 3 ukazują skutki zmian stopy podatkowej w przypadku, gdy wpływy podatkowe są proporcjonalne do dochodów, czyli stopa podatkowa nie jest uzależniona od fluktuacji produkcji. Władze fiskalne mogą jednak wpływać na kształtowanie się stopy podatkowej w ramach cyklu prowadząc antycykliczną lub procykliczną politykę podatkową ${ }^{19}$. Z tego względu, podobnie jak w przypadku strony wydatkowej finansów publicznych, na podstawie modelu poddano analizie efekty pro- $i$ antycyklicznej polityki podatkowej. W przypadku obniżenia stawek podatkowych w reakcji na wzrost produkcji polityka fiskalna będzie miała charakter antycykliczny. Natomiast podwyższanie stawek podatkowych w reakcji na obniżenie produkcji skutkować będzie wzrostem fluktuacji gospodarczych.

Tabela 4 zawiera informacje o odchyleniach standardowych zmiennych w przypadku prowadzenia antycyklicznej i procyklicznej polityki podatkowej. Dla polityki fiskalnej antycyklicznej przyjęto $\kappa_{\tau}=0,5$, natomiast dla procyklicznej $\kappa_{\tau}=-0,5$.

Tabela 4. Odchylenia standardowe zmiennych symulowanych w przypadku prowadzenia procyklicznej i antycyklicznej polityki fiskalnej dotyczącej stóp podatkowych

\begin{tabular}{|l|c|c|}
\hline \multirow{2}{*}{\multicolumn{1}{|c|}{ Zmienna }} & \multicolumn{2}{|c|}{$\begin{array}{c}\text { Odchylenie standardowe zmiennej w relacji do jej odchylenia } \\
\text { standardowego w przypadku prowadzenia polityki acyklicznej }\end{array}$} \\
\cline { 2 - 3 } & polityka procykliczna & polityka antycykliczna \\
\hline Produkcja & 1,114 & 0,922 \\
\hline Zatrudnienie & 1,087 & 0,971 \\
\hline Kapitał & 1,112 & 0,906 \\
\hline Inwestycje & 1,176 & 0,854 \\
\hline Konsumpcja & 1,111 & 0,902 \\
\hline Wydatki rządowe & 1,000 & 1,000 \\
\hline Stopa podatkowa & 1,029 & 1,029 \\
\hline $\begin{array}{l}\text { Łączna produktywność } \\
\text { czynników produkcji }\end{array}$ & 1,000 & 1,000 \\
\hline
\end{tabular}

Źródło: opracowanie własne na podstawie danych Eurostatu, GUS i Ministerstwa Finansów.

${ }^{19} \mathrm{~W}$ rozdziale cykliczność polityki fiskalnej oceniana jest na podstawie kształtowania się stóp podatkowych, a nie wpływów podatkowych, które w sposób automatyczny zmieniają się wraz z wahaniami koniunktury, działając jako automatyczne stabilizatory koniunktury (por. rozdz. 5). 
Kierunek oddziaływania spadku stóp podatkowych na pozostałe zmienne (produkcję, kapitał, konsumpcję i zatrudnienie) jest taki sam jak w przypadku wystąpienia szoku technologicznego polegającego na zwiększeniu się łącznej produktywności czynników produkcji. W rezultacie procykliczna polityka fiskalna, polegająca na obniżaniu stóp podatkowych w reakcji na wzrost produkcji, zwiększa wahania PKB i pozostałych zmiennych. Natomiast polityka antycykliczna jest w tym przypadku skutecznym narzędziem ograniczania nie tylko wahań produkcji, ale także konsumpcji, zatrudnienia i ilości kapitału ${ }^{20}$.

$\mathrm{Na}$ podstawie modelu otrzymuje się, że polityka podatkowa w większym stopniu wpływa na kształtowanie się zatrudnienia, niż na poziom kapitału. W rezultacie, przy wystarczająco silnej antycyklicznej polityce fiskalnej, zmiany łącznej produktywności czynników produkcji i zatrudnienia mogą przebiegać w przeciwnych kierunkach. Wynikający z szoku technologicznego wzrost produkcji powoduje w takim przypadku podwyższenie stóp podatkowych, które na tyle silnie oddziałują na poziom zatrudnienia, że wraz z dodatnim szokiem technologicznym następuje obniżenia się poziomu zatrudnienia.

W przedstawionej do tej pory analizie przyjmowano upraszczające założenie, że w gospodarce występuje jedna stawka podatkowa. W rzeczywistych gospodarkach dla każdego z czynników produkcji stopy podatkowe mogą się kształtować na odmiennym poziomie. Jednocześnie siła i kierunek oddziaływania zmian stóp podatkowych uzależnione są od tego, jakiego rodzaju podatku dotyczą. $\mathrm{Z}$ tego względu model rozszerzono o występowanie podatków nakładanych na poszczególne czynniki produkcji.

Przy uwzględnieniu, że podatki nakładane na dochody z kapitału i wynagrodzenia mogą być różnej wysokości ograniczenie budżetowe państwa określa równanie postaci:

$$
\sum_{t=1}^{\infty} \frac{\tau_{w, t} w_{t} l_{t}+\tau_{k, t}\left(\rho_{t}-\delta\right) k_{t}+T_{t}}{\pi_{j=1}^{t}\left(1+\left(1-\tau_{k, j}\right) r_{j}\right)}=\sum_{t=1}^{\infty} \frac{g_{t}^{B}+i_{t}^{G}+T r_{t}}{\pi_{j=1}^{t}\left(1+\left(1-\tau_{k, j}\right) r_{j}\right)},
$$

gdzie:

$$
\tau_{w, t}, \tau_{k, t} \in(0,1) \text {. }
$$

Ograniczenie budżetowe gospodarstwa domowego jest natomiast określone równaniem:

$$
k_{0}+\sum_{t=1}^{\infty} \frac{\left(1-\tau_{w, t}\right) w_{t} l_{t}-T_{t}+T_{t}}{\pi_{j=1}^{t}\left[1+\left(1-\tau_{k, j}\right) r_{j}\right]}=\sum_{t=1}^{\infty} \frac{c_{t}}{\pi_{j=1}^{t}\left[1+\left(1-\tau_{k, j}\right) r_{j}\right]} .
$$

${ }^{20}$ Jak wskazano we wcześniejszej części rozdziału, polityka antycykliczna polegająca na zmianach wydatków rządowych w ramach cyklu prowadzi natomiast do wzrostu fluktuacji konsumpcji i kapitału. 
Pozostałe założenia są analogiczne jak w modelu, w którym występuje tylko jedna stopa opodatkowania dochodów. Analogicznie jak w wersji modelu z jedną stopą podatkową, przedmiot analizy stanowi reakcja symulowanej gospodarki na jednorazowe, przejściowe zmiany dotyczące opodatkowania dochodów z kapitału oraz wynagrodzeń. Skutki makroekonomiczne trwającego cztery kwartały zwiększenia o 1 pkt proc. opodatkowania dochodów z kapitału i dochodów z pracy przedstawiono na rysunku 4 i 5.
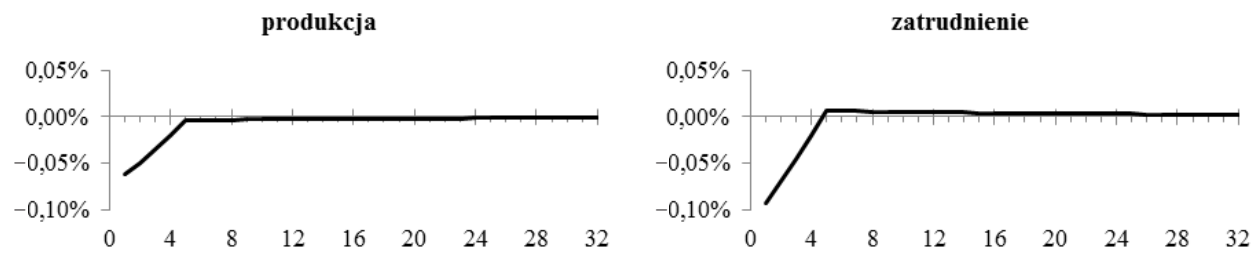

kapital

inwestycje
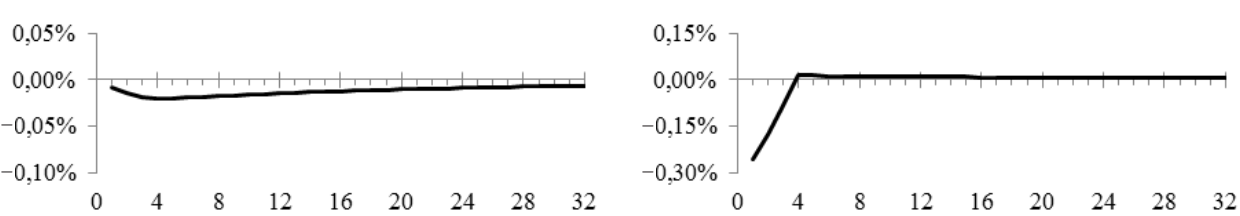

konsumpcja

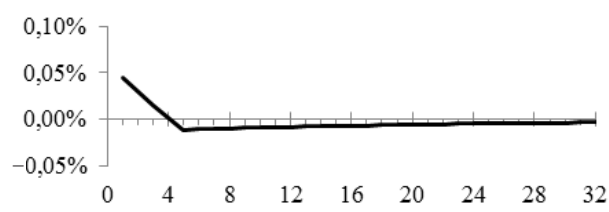

Rysunek 4. Efekty przejściowego, trwającego jeden rok, wzrostu stopy opodatkowania dochodów z kapitału o 1 pkt proc. na procentowe odchylenie zmiennych od poziomu bazowego (dane kwartalne)

Źródło: opracowanie własne na podstawie danych Eurostatu, GUS i Ministerstwa Finansów.

Jak wynika z danych przedstawionych na rysunku 4, wzrost opodatkowania dochodów z kapitału zmniejsza poziom kapitału i zatrudnienie, a w efekcie obniża poziom produkcji. Jednocześnie zwiększeniu ulega konsumpcja, ponieważ w okresie wyższego opodatkowania dochodów z kapitału gospodarstwa domowe zastępują część kapitału, przynoszącego w tym okresie niższe dochody po opodatkowaniu, konsumpcją. W rezultacie, w czasie trwania szoku fiskalnego zmienia się struktura agregatowego popytu - zmniejsza się udział inwestycji, a rośnie udział konsumpcji. 

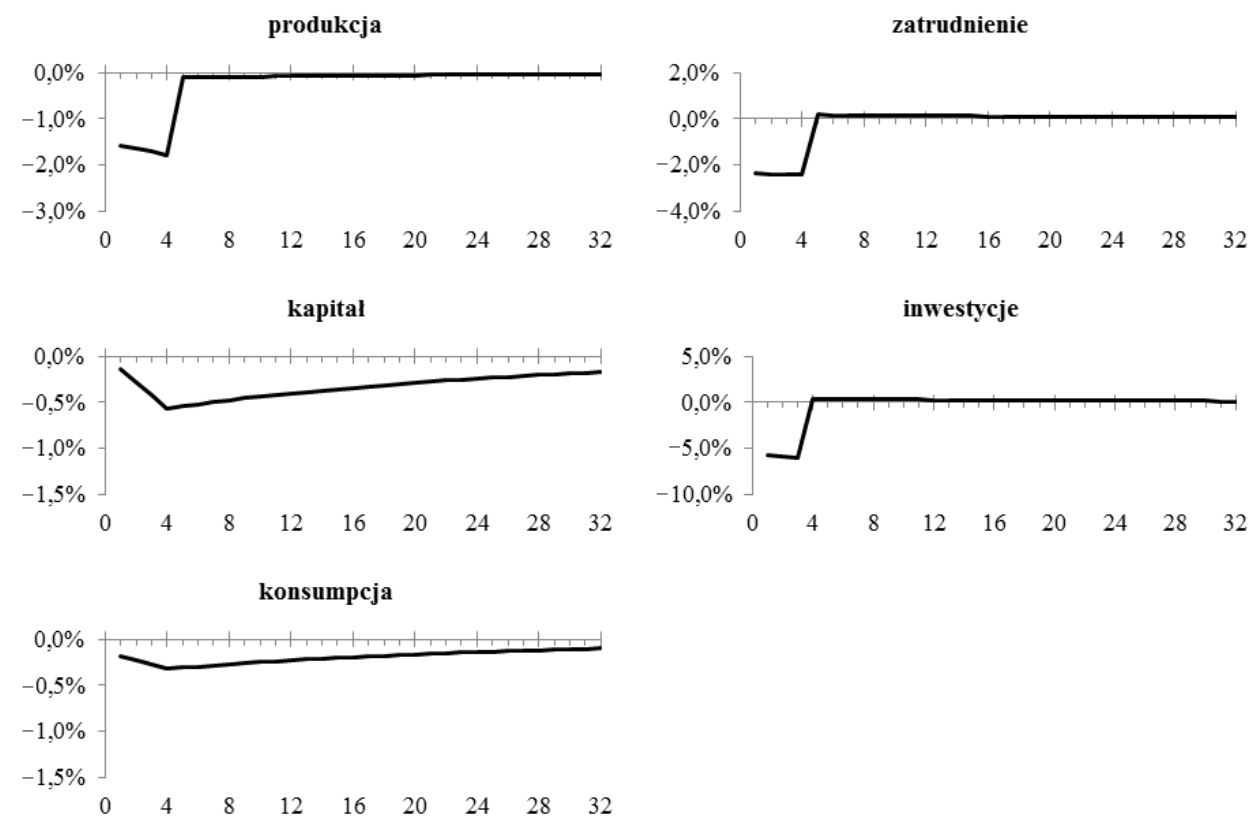

Rysunek 5. Efekty przejściowego, trwającego jeden rok, wzrostu stopy opodatkowania wynagrodzeń o 1 pkt proc. na procentowe odchylenie zmiennych od poziomu bazowego (dane kwartalne)

Źródło: opracowanie własne na podstawie danych Eurostatu, GUS i Ministerstwa Finansów.

Spadek zatrudnienia w wyniku zwiększenia stopy podatkowej nakładanej na dochody z pracy jest wynikiem zmniejszenia się krańcowego produktu pracy po opodatkowaniu. Obniżeniu ulega również ilość kapitału, ponieważ z jednej strony przy niższym poziomie zatrudnienia maleje krańcowy produkt kapitału, a z drugiej strony kapitał zamieniany jest na konsumpcję w celu ograniczenia wahań konsumpcji. Po powrocie stopy podatkowej do poziomu wyjściowego kapitał zostaje stopniowo odbudowywany, a konsumpcja stopniowo ulega zwiększeniu, jednak jeszcze przez wiele okresów utrzymując się poniżej poziomu sprzed szoku.

Z przeprowadzonych symulacji wynika, że przejściowa zmiana opodatkowania wynagrodzeń wywiera silniejszy podażowy wpływ zarówno na poziom kapitału, jak i zatrudnienia. W rezultacie spadek produkcji będący następstwem zwiększenia stopy opodatkowania dochodów z pracy jest znacznie większy niż w przypadku zmian dotyczących opodatkowania dochodów z kapitału.

Podobne wnioski dotyczące podażowego wpływu przejściowych zmian opodatkowania poszczególnych czynników produkcji na PKB otrzymali Bukowski 
i in. $(2005)^{21}$. Również z modelu RBC dla gospodarki amerykańskiej wynika, że zmiany opodatkowania zatrudnienia poprzez mechanizmy podażowe silniej oddziałują na wahania produkcji niż zmiany opodatkowania kapitału (por. Totzek i Winkler, 2010) ${ }^{22}$.

\subsection{Oddziaływanie wydatków rządowych finansowanych podatkami zależnymi od dochodu}

W dotychczasowej analizie przyjmowano, że polityka fiskalna oddziaływać może na gospodarkę poprzez:

- zmiany wydatków rządowych finansowanych zryczałtowanymi podatkami lub, zgodnie z ekwiwalencją ricardiańską, deficytem budżetowym,

- zmiany stóp podatkowych.

Podniesienie wydatków rządowych, finansowanych deficytem budżetowym lub podatkami niezależnymi od dochodu, których rozkład nie oddziałuje na decyzje gospodarstw domowych, prowadzi do wzrostu produkcji i zatrudnienia. Natomiast zwiększenie stopy opodatkowania dochodów negatywnie oddziałuje na poziom tych zmiennych. Kierunek wpływu wydatków rządowych oraz stóp podatkowych na poziom produkcji jest zatem odmienny. Podażowe efekty zwiększenia wydatków rządowych finansowanego poprzez podniesienie stopy opodatkowania nie są więc jednoznaczne i zależą od uwarunkowań danej gospodarki. $\mathrm{Z}$ tego względu, na gruncie modelu RBC dla gospodarki polskiej, poddano analizie podażowe oddziaływanie zwiększenia wydatków rządowych finansowanego wyższymi podatkami zależnymi od dochodu.

W przypadku tak prowadzonej polityki fiskalnej w reakcji na szoki dotyczące wydatków rządowych następuje dostosowanie się stopy podatkowej w celu utrzymania salda budżetowego na niezmienionym poziomie. Zatem stopa podatkowa w wyniku szoków dotyczących wydatków rządowych zmienia się zgodnie z równaniem (94). Rysunek 6 przedstawia podażowe skutki przejściowego zwiększania wydatków rządowych, sfinansowanego podwyżką stopy opodatkowania dochodów.

${ }^{21}$ Jednocześnie, jak wskazują Bukowski i in. (2005), w przypadku trwałych zmian negatywne oddziaływanie podniesienia stóp podatkowych na produkcję jest większe w przypadku zwiększenia opodatkowania dochodów z kapitału.

${ }^{22}$ Totzek i Winkler (2010) otrzymali, że krótkookresowy mnożnik fiskalny w przypadku opodatkowania wynagrodzeń wynosi - 0,94 , natomiast w przypadku opodatkowania dochodów z kapitału kształtuje się na poziomie - 0,64 . 

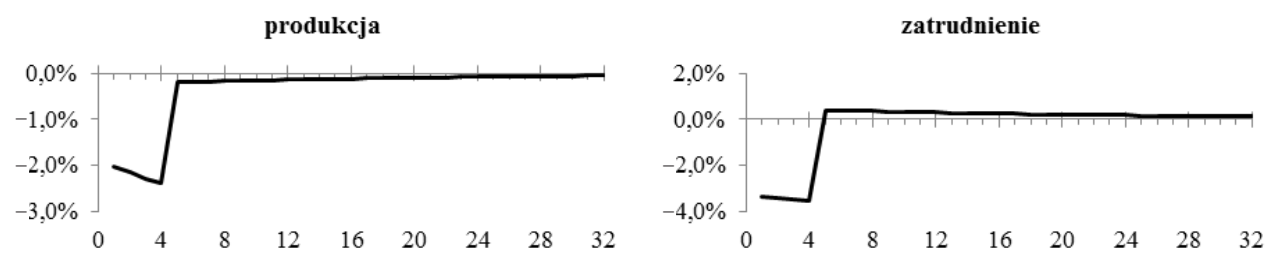

kapital

inwestycje
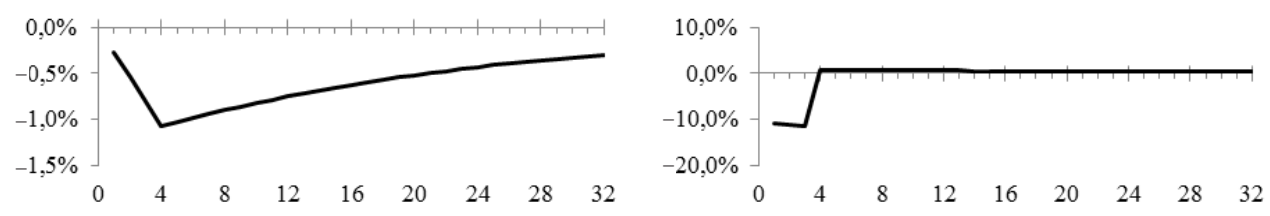

konsumpcja

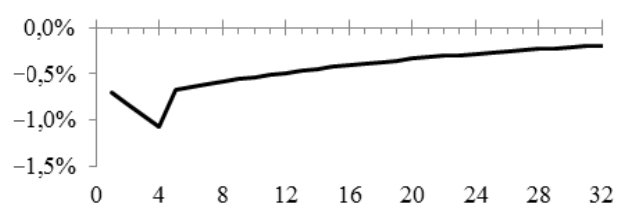

Rysunek 6. Oddziaływanie przejściowego, trwającego jeden rok, wzrostu wydatków rządowych o 1\% PKB finansowanego podwyżką stopy opodatkowania dochodów na procentowe odchylenie poszczególnych zmiennych od poziomu bazowego (dane kwartalne)

Źródło: opracowanie własne na podstawie danych Eurostatu, GUS i Ministerstwa Finansów.

Wzrost wydatków rządowych, któremu towarzyszy wzrost stopy opodatkowania, powoduje ograniczenie zarówno ilości produkcji, konsumpcji, kapitału prywatnego, jak i zatrudnienia. W efekcie przejściowego zwiększenia o $1 \%$ PKB wydatków rządowych, sfinansowanego wyższymi podatkami zależnymi od dochodu, następuje obniżenie się PKB o ponad $2 \%{ }^{23}$. Uzyskano więc odmienny kierunek oddziaływania polityki fiskalnej na fluktuacje produkcji, niż w sytuacji, gdy wydatki rządowe są finansowane zryczałtowanymi podatkami.

Znaczne obniżenie się konsumpcji oraz kapitału prywatnego wynika z faktu, że zarówno wyższe wydatki rządowe, jak i stopa podatkowa wywierają negatywny wpływ na poziom tych zmiennych ${ }^{24}$. Natomiast spadek produkcji i zatrudnienia w wy-

${ }^{23}$ Porównując symulacje przedstawione na rysunkach 3 oraz 6 zaobserwować można, że polityka fiskalna polegająca na podniesieniu stopy opodatkowania dochodów o 1 pkt proc., w mniejszym stopniu negatywnie oddziałuje na PKB niż podniesienie wydatków rządowych sfinansowane podwyżką podatków zależnych od dochodu o $1 \%$ PKB. Wynika to z faktu, że drugi z ww. wariantów polityki fiskalnej, ze względu na negatywny wpływ wyższego opodatkowania na produkcję, pociąga za sobą podniesienie stopy opodatkowania o więcej niż 1 pkt proc.

${ }^{24}$ Ze względu na wzmacniające się negatywne oddziaływanie na pożądany zasób kapitału wyższych wydatków rządowych oraz wyższej stopy podatkowej następuje też bardzo silne obniżenie się poziomu inwestycji. 
niku analizowanego szoku fiskalnego oznacza, że negatywny wpływ wzrostu opodatkowania na analizowane zmienne jest silniejszy niż pozytywne oddziaływanie wzrostu wydatków rządowych ${ }^{25}$. Z jednej strony bowiem wzrost wydatków rządowych poprzez negatywny efekt majątkowy powoduje ograniczenie czasu wolnego, a co za tym idzie - wzrost zatrudnienia. Wyższe zatrudnienie wpływa z kolei na wzrost PKB. Równocześnie jednak, wraz ze wzrostem wydatków rządowych, w celu jego sfinansowania, następuje podwyższenie stopy opodatkowania dochodów. Na skutek wzrostu stopy podatkowej dochodzi do obniżenia się krańcowego produktu kapitału oraz krańcowego produktu pracy po opodatkowaniu. W rezultacie zmniejsza się poziom kapitału i zatrudnienia, a w efekcie ograniczeniu ulega wysokość produkcji.

Również w pracy Bukowskiego i in. (2005) otrzymano, że wzrost wydatków rządowych finansowany niezryczałtowanymi podatkami skutkuje obniżeniem się produkcji. Według oszacowań przywołanych autorów negatywny wpływ na PKB takiej polityki fiskalnej jest jednak znacznie słabszy niż wynika to z symulacji przedstawionych na rysunku $6^{26}$. Jak wspomniano wcześniej, różnice w uzyskanych rezultatach mogą wynikać z innych oszacowań parametrów, a także z odmiennej specyfikacji funkcji użyteczności.

Otrzymane w pracy oszacowania, wskazujące na silny negatywny podażowy wpływ zwiększania wydatków rządowych, któremu towarzyszy podwyżka stóp podatkowych, są zbliżone do oszacowań, które na podstawie modelu RBC dla gospodarki amerykańskiej otrzymali Baxter i King (1993). Według Baxter i Kinga zwiększenie o $1 \%$ PKB wydatków rządowych finansowanych podatkami zależnymi od dochodu prowadzi od obniżenia się PKB o ponad 2,5\%. Z drugiej strony $\mathrm{z}$ analiz, które przeprowadzili Totzek i Winkler (2010) wynika, że w gospodarce amerykańskiej negatywne skutki tego typu polityki fiskalnej są znacznie słabsze ${ }^{27}$.

\section{Podsumowanie}

W rozdziale zbadano podażowe oddziaływanie wydatków rządowych oraz podatków na fluktuacje gospodarcze w Polsce. Analizę przeprowadzono opierając się na należącym do grupy modeli realnego cyklu koniunkturalnego modelu Hansena (1985) z niepodzielną pracą, który zaimplementowano do warunków gospodarki polskiej i rozszerzono o założenia dotyczące polityki fiskalnej.

${ }^{25}$ Zbliżone rezultaty uzyskuje się na podstawie modelu Aschauera (por. Krajewski, 2011).

${ }^{26}$ Według Bukowskiego i in. (2005) przejściowe zwiększenie o 1\% PKB wydatków rządowych finansowane podatkiem PIT poprzez efekty podażowe prowadzi do przejściowego ograniczenia produkcji o ok. $0,9 \%$.

${ }^{27} \mathrm{Na}$ podstawie modelu RBC dla gospodarki amerykańskiej Totzek i Winkler (2010) szacują, że przejściowe podniesienie wydatków rządowych o $1 \%$ PKB sfinansowane wyższymi podatkami niezryczałtowanymi powoduje przejściowe obniżenie się produkcji o $0,84 \%$. 
Z przeprowadzonych symulacji wynika, że model relatywnie dobrze odwzorowuje korelacje pomiędzy wielkością PKB i pozostałymi zmiennymi. W szczególności, porównanie wyników modelu z rezultatami otrzymanymi przez Kuchtę i Piłat (2010) ukazuje, że rozszerzenie modelu o politykę fiskalną zmniejsza korelację pomiędzy łączną produktywnością czynników produkcji a produkcją, przybliżając ją do wielkości występującej w gospodarce polskiej. Nie ma natomiast potwierdzenia $\mathrm{w}$ danych rzeczywistych wynikająca $\mathrm{z}$ modelu ujemna zależność pomiędzy wydatkami rządowymi i konsumpcją.

W analizowanym modelu wzrost wydatków rządowych finansowany deficytem budżetowym lub podatkami nie uzależnionymi od dochodu wpływa na zwiększenie PKB poprzez dwa wzmacniające się efekty podażowe. Po pierwsze, negatywny efekt majątkowy powoduje ograniczenie czasu wolnego oraz wzrost zatrudnienia i produkcji. Po drugie, będący następstwem wyższych inwestycyjnych wydatków rządowych wzrost kapitału publicznego oddziałuje na możliwości wytwórcze. Z przeprowadzonych symulacji wykonanych w oparciu o oszacowane dla gospodarki polskiej parametry wynika, że przejściowy wzrost wydatków rządowych o $1 \%$ PKB powoduje przejściowe zwiększenie produkcji o ok. $0,2 \%$. Otrzymano więc podażowe mnożniki wydatków rządowych zbliżone do oszacowań Bukowskiego i in. (2005), a niższe niż uzyskali na podstawie modelu realnego cyklu koniunkturalnego Totzek i Winkler (2010) dla gospodarki amerykańskiej.

Funkcje reakcji na impuls wskazują, że zwiększenie w wydatkach rządowych udziału wydatków majątkowych wywiera pozytywny wpływ na gospodarkę w sposób relatywnie trwały podwyższa produkcję, konsumpcję, zatrudnienie i poziom kapitału. $\mathrm{Z}$ modelu wynika też, że antycykliczne kształtowanie wydatków rządowych co prawda zmniejsza fluktuacje produkcji, ale jednocześnie prowadzi do zwiększenia wahań kapitału i konsumpcji. Zatem antycykliczna polityka fiskalna nie jest $\mathrm{w}$ tym przypadku skutecznym narzędziem niwelowania wynikających z fluktuacji gospodarczych wahań konsumpcji prywatnej.

Dekompozycja wydatków rządowych na poszczególne kategorie wskazuje, że wydatki majątkowe wpływają w sposób relatywnie trwały na kształtowanie się produkcji. Wzrost wydatków bieżących wywiera natomiast jedynie przejściowy wpływ na poziom PKB. Ponadto im silniejszym substytutem konsumpcji prywatnej jest konsumpcja publiczna, tym słabsze oddziaływanie wydatków rządowych na kształtowanie się produkcji. Jeśli konsumpcja publiczna jest doskonałym substytutem konsumpcji prywatnej, wówczas zwiększenie wydatków rządowych powoduje analogiczne zmniejszenie konsumpcji prywatnej i nie oddziałuje na pozostałe zmienne makroekonomiczne.

Przedstawione w rozdziale wyniki symulacji ukazują, że podażowe skutki zwiększenia wydatków rządowych są w kliku aspektach odmienne niż efekty popytowe. Przede wszystkim przeciwny jest kierunek oddziaływania na konsumpcję 
prywatną, co m.in. rzutuje na odmienne skutki prowadzenia antycyklicznej polityki fiskalnej.

Analizie poddano również oddziaływanie zmian stóp podatkowych na fluktuacje gospodarcze w Polsce. Z modelu wynika, że na skutek wzrostu stopy opodatkowania dochodów następuje obniżenie się poziomu kapitału i zatrudnienia. Przy czym, o ile zatrudnienie wraca do poziomu wyjściowego już po roku, to negatywny wpływ wyższego opodatkowania na kształtowanie się ilości kapitału jest bardziej długotrwały. W efekcie obniżenia się obydwu czynników produkcji silnemu zmniejszeniu ulega również PKB. Z przeprowadzonych symulacji wynika, że przejściowe zwiększenie stopy opodatkowania dochodów o 1 pkt proc. powoduje obniżenie produkcji aż o $2 \%$. Wynikające z modelu negatywne oddziaływanie wyższego opodatkowania jest więc znacznie silniejsze niż w modelu RBC opracowanym przez Bukowskiego i in. (2005).

Na podstawie przeprowadzonych symulacji zaobserwować można, że antycykliczna polityka fiskalna, polegająca na podwyższaniu stóp podatkowych w reakcji na wzrost produkcji, jest skutecznym narzędziem ograniczania nie tylko wahań produkcji, ale także konsumpcji, zatrudnienia i ilości kapitału. Warto przy tym zaznaczyć, że ponieważ polityka podatkowa w większym stopniu wpływa na kształtowanie się poziomu zatrudnienia niż na poziom kapitału, zatem przy silnej antycyklicznej reakcji fiskalnej na dodatni szok technologiczny wraz ze wzrostem PKB nastąpić może nawet obniżenie się poziomu zatrudnienia.

$\mathrm{Na}$ podstawie analizowanego modelu zbadano podażowe oddziaływanie zmian stawek podatkowych $\mathrm{w}$ dekompozycji na podatki nakładane na poszczególne czynniki produkcji. Porównując wynikające z modelu efekty zmian w opodatkowaniu dochodów z kapitału i pracy zaobserwować można, że zmiana opodatkowania wynagrodzeń wywiera większy podażowy wpływ na gospodarkę niż zmiana opodatkowania dochodów z kapitału. Na skutek zwiększenia podatków nakładanych na wynagrodzenia silniejszemu ograniczeniu ulega przy tym nie tylko zatrudnienie, ale także poziom kapitału.

Wzrost wydatków rządowych finansowany deficytem budżetowym prowadzi do wzrostu produkcji, natomiast podniesienie stopy podatkowej - do ograniczenia PKB. W ramach przeprowadzonych symulacji zbadano zatem, w jaki sposób oddziałuje na produkcję podwyższenie wydatków rządowych sfinansowane wyższym opodatkowaniem dochodów. Otrzymano, że w przypadku finasowania wzrostu wydatków rządowych podatkami zależnymi od dochodu następuje ograniczenie poziomu zatrudnienia, kapitału, konsumpcji oraz produkcji. Uzyskano więc odmienny kierunek oddziaływania polityki fiskalnej na fluktuacje produkcji i zatrudnienia niż w sytuacji, gdy wydatki rządowe są finansowane deficytem budżetowym lub zryczałtowanymi podatkami. 


\section{Oddziaływanie wydatków rządowych i podatków na wahania koniunktury w Polsce $w$ świetle modelu nowokeynesistowskiego}

\section{Wprowadzenie}

Analizę skutków polityki fiskalnej w gospodarce polskiej przy występowaniu sztywności nominalnych przeprowadzono opierając się na nowokeynesistowskim modelu Smetsa i Woutersa (2003), który w odróżnieniu od modelu realnego cyklu koniunkturalnego uwzględnia popytowe efekty polityki fiskalnej, szczególnie istotne w okresie kryzysu. Model Smetsa i Woutersa stanowi rozwinięcie omówionego $\mathrm{w}$ rozdziale drugim podstawowego modelu nowokeynesistowskiego o występowanie funkcji inwestycji, przyzwyczajeń konsumpcyjnych, częściowej indeksacji cen i płac, zmiennego stopnia wykorzystania kapitału oraz kosztów dostosowania ilości kapitału (por. King, Rebelo 2000; Ravn, Schmitt-Grohe, Uribe, 2006; Grabek, Kłos, Utzig-Lenarczyk, 2007; Kuchta, 2012).

W modelach nowej ekonomii keynesistowskiej zawierających funkcję inwestycji, odmiennie niż w podstawowym modelu nowokeynesistowskim, a podobnie jak w modelach realnego cyklu koniunkturalnego, akumulacja kapitału jest objaśniana $\mathrm{w}$ ramach modelu, dzięki czemu możliwa jest analiza oddziaływania szoków na obydwa czynniki produkcji (por. Gali, 2008). Zatem zastosowanie w pracy modelu Smetsa i Woutersa zapewnia większą, niż w przypadku podstawowego modelu nowokeynesistowskiego, porównywalność wyników z rezultatami uzyskanymi na podstawie modelu RBC. Ważne założenie modelu stanowi występowanie przyzwyczajeń konsumpcyjnych. Jak przedstawiono w rozdziale drugim przesłanki teoretyczne wskazują bowiem, że przyzwyczajenia konsumpcyjne mogą mieć istotne znaczenie z punktu widzenia charakteru oddziaływania polityki fiskalnej na gospodarkę, w tym na kształtowanie się konsumpcji prywatnej. Warto przy tym zaznaczyć, że mimo rozbudowanej struktury modelu Smetsa-Woutersa, nie jest on wolny od potencjalnych ograniczeń nowokeynesistowskich modeli DSGE, do których zaliczyć można m.in. możliwość wystąpienia błędów specyfikacji (por. Gali i in., 2005; Canova, Sala, 2009).

Analizowany w rozdziale model uwzględnia występowanie sztywności nominalnych zarówno cen, jak i płac. Ceny oraz płace ustalane są zgodnie ze schematem Calvo (1983). Porównanie wyników symulacji przeprowadzonych dla różnych wartości parametrów określających poziom sztywności nominalnych umożliwia dekompozycję oddziaływania polityki fiskalnej na komponent popytowy i podażowy. 
Dla potrzeb analizy skutków polityki fiskalnej model Smetsa i Woutersa rozszerzono o dodatkowe założenia dotyczące polityki fiskalnej, tj. występowanie podatków zależnych od dochodu oraz podatków nakładanych na poszczególne czynniki produkcji. Model zaimplementowano do warunków gospodarki polskiej poprzez estymację parametrów modelu na podstawie danych kwartalnych dla gospodarki polskiej z lat 1995-2010. Zastosowano estymację bayesowską, stanowiącą w ostatnich latach jedną z częściej stosownych metod estymacji parametrów modeli nowokeynesistowskich (por. np. Ferroni, 2010).

Struktura rozdziału jest następująca: w pierwszej kolejności przedstawiono założenia modelu; następnie ukazane zostały wyniki bayesowskiej estymacji parametrów. W dalszych częściach rozdziału poddano kolejno analizie wynikające z modelu oddziaływanie wydatków rządowych finansowanych zryczałtowanymi podatkami, stóp podatkowych oraz wydatków rządowych finansowanych podatkami zależnymi od dochodu. W końcowej części rozdziału zawarto podsumowanie oraz wnioski wynikające z przeprowadzonych symulacji.

\subsection{Założenia modelu}

W modelu zakłada się, że występuje kontinuum gospodarstw domowych indeksowanych względem $j, j \in<0,1>$. Gospodarstwa domowe maksymalizują wartość oczekiwaną sumy zdyskontowanych użyteczności postaci ${ }^{1}$ :

$$
U=E_{t} \sum_{t=0}^{\infty} \beta^{t} u\left(C_{t}^{j}-v_{t}, l_{t}^{j}\right)
$$

Wpływ przyzwyczajeń konsumpcyjnych $\left(v_{t}\right)$ określony jest równaniem:

$v_{t}=a_{v} C_{t-1}$,

gdzie $a_{v} \in(0,1)^{2}$.

Funkcja użyteczności gospodarstwa domowego przyjmuje postać:

$u_{t}=\varepsilon_{t}^{\text {pref }}\left(\frac{1}{1-\sigma_{c}}\left(C_{t}^{j}-v_{t}\right)^{1-\sigma_{c}}-\frac{\varepsilon_{t}^{l}}{1+\sigma_{l}}\left(l_{t}^{j}\right)^{1+\sigma_{l}}\right)$,

${ }^{1}$ Wielkości dotyczące dóbr finalnych, wytwarzanych w oparciu o dobra pośrednie, analogicznie jak w rozdziale drugim, oznaczone są wielkimi literami. Natomiast dobra pośrednie oznaczono małymi literami z subskryptem $i$.

${ }^{2}$ Zatem w modelu przyzwyczajenia konsumpcyjne uzależnione są od konsumpcji w skali całej gospodarki w poprzednim okresie. Bardziej rozwiniętą wersję przyzwyczajeń konsumpcyjnych, gdy na przyzwyczajenia wpływa również poziom konsumpcji w skali gospodarki we wcześniejszych okresach omówiono w rozdziale drugim. Natomiast analizy, w których przyzwyczajenia konsumpcyjne zależą od wcześniejszej indywidualnej konsumpcji danego gospodarstwa domowego przedstawiają Christiano, Eichenbaum i Evans (2005) oraz Fernandez-Villaverde (2010). 
gdzie:

$\sigma_{c}$ - odwrotność międzyokresowej elastyczności substytucji konsumpcji,

$\sigma_{l}$-odwrotność elastyczności podaży pracy względem realnej stawki płac,

$\varepsilon_{t}^{\text {pref }}$ - szok dotyczący preferencji w czasie, określony równaniem (145),

$\varepsilon_{t}^{l}$ - szok oddziałujący na podaż pracy, zdefiniowany przez proces postaci:

$\varepsilon_{t}^{l}=\rho_{\varepsilon, l} \varepsilon_{t-1}^{l}+\zeta_{l, t}, \zeta_{l, t} \sim N\left(0, \sigma_{\zeta, l}{ }^{2}\right), \rho_{\varepsilon, l} \in(0,1)$.

W modelu zakłada się, że gospodarstwa domowe przechowują majątek finansowy w postaci jednookresowych obligacji $\left(B_{t}^{j}\right)$. Ograniczenie budżetowe gospodarstw domowych przyjmuje więc postać:

$P_{t}^{B} \frac{B_{t}^{j}}{P_{t}}+C_{t}^{j}+I_{t}^{j}=\frac{B_{t-1}^{j}}{P_{t}}+Y_{t}^{j}$,

gdzie:

$Y_{t}^{j}$ - dochody netto $j$-tego gospodarstwa domowego,

$I_{t}^{j}$ - inwestycje $j$-tego gospodarstwa domowego,

$P_{t}^{B}$ - cena obligacji.

Równanie (207) można również zapisać w postaci:

$\frac{B_{t}^{j}}{R_{t} P_{t}}+C_{t}^{j}+I_{t}^{j}=\frac{B_{t-1}^{j}}{P_{t}}+Y_{t}^{j}$,

gdzie $R_{t}$ oznacza nominalną całkowitą stopę zwrotu z obligacji, zdefiniowaną następująco:

$R_{t}=\frac{1}{P_{t}^{B}}=1+r_{t}^{n}$.

Na dochód gospodarstw domowych składają się następujące rodzaje dochodów:

- dochody z pracy,

- wypłaty wynikające z uczestnictwa w systemie ubezpieczeniowym,

- dochody z wykorzystywanego kapitału pomniejszone o koszty związane z niepełnym lub nadmiernym stopniem wykorzystania kapitału,

- dywidendy wypłacane przez firmy działające w warunkach konkurencji monopolistycznej,

- transfery z budżetu państwa.

Występowanie systemu ubezpieczeniowego powoduje, że wszystkie gospodarstwa otrzymują identyczny dochód netto z pracy powiększony o wypłaty z systemu ubezpieczeń. W rezultacie każde gospodarstwo domowe uzyskuje taką samą krańcową użyteczność wynikającą ze wzrostu poziomu majątku. W modelu Smetsa i Woutersa, analogicznie jak w pracach Greenwooda, Hercowitza 
i Huffmanna (1988) oraz Kinga i Rebelo (2000), uwzględnia się możliwość niepełnego wykorzystania kapitału oraz przyjmuje się, że niepełny (lub nadmierny) stopień wykorzystaniu kapitału wiąże się z dodatkowymi kosztami.

Wszystkie dochody gospodarstwa domowego są opodatkowane według stopy podatkowej $\tau_{t}$. W rezultacie dochody netto gospodarstwa domowego określa wzór postaci:

$Y_{t}^{j}=\left(1-\tau_{t}\right)\left(w_{t}^{j} l_{t}^{j}+r_{t}^{K} u_{K, t}^{j} k_{t}^{j}-\Psi\left(u_{K, t}^{j}\right) k_{t-1}^{j}+D_{t}^{j}\right)+A_{t}^{j}+T r_{t}^{j}-T_{t}^{j}$,

gdzie:

$w_{t}^{j}$ - realna stawka płac uzyskiwana przez $j$-te gospodarstwo domowe,

$k_{t}^{j}$ - kapitał rzeczowy posiadany przez $j$-te gospodarstwo domowe,

$u_{K, t}^{j}-$ stopień wykorzystania kapitału rzeczowego,

$D_{t}^{j}$ - dywidendy wypłacane $j$-temu gospodarstwu domowemu przez przedsiębiorstwa działające w konkurencji monopolistycznej,

$A_{t}^{j}$ - wypłaty z ubezpieczenia otrzymywane przez $j$-te gospodarstwo domo$\mathrm{we}^{3}$,

$\Psi\left(u_{K, t}^{j}\right)$ - koszty związane z niepełnym lub nadmiernym stopniem wykorzystania kapitału ${ }^{4}$

$$
\begin{aligned}
& \Psi(1)=0, \Psi\left(u_{K, t}^{j}\right)>0 \text { dla } u_{K, t}^{j} \in(0,1) \text { lub } u_{K, t}^{j}>1, \\
& \Psi^{\prime}\left(u_{K, t}^{j}\right)<0 \text { dla } u_{K, t}^{j} \in(0,1), \Psi^{\prime}\left(u_{K, t}^{j}\right)>0 \text { dla } u_{K, t}^{j}>1 .
\end{aligned}
$$

Na podstawie funkcji użyteczności (205) przy ograniczeniu budżetowym (207) otrzymuje się, że gospodarstwo domowe w celu maksymalizacji wartości oczekiwanej sumy zdyskontowanych użyteczności podejmuje takie decyzje dotyczące poziomu konsumpcji i obligacji, aby spełniony był warunek:

$E_{t}\left(\beta \frac{u_{c, t+1}^{j}}{u_{c, t}^{j}} \frac{R_{t} P_{t}}{P_{t+1}}\right)=1$,

gdzie:

$u_{c, t}^{j}-$ krańcowa użyteczność konsumpcji j-tego gospodarstwa domowego.

${ }^{3} \mathrm{~W}$ modelu zakłada się, że dochody z ubezpieczeń nie są opodatkowane, a wszystkie gospodarstwa otrzymują identyczny dochód netto z pracy powiększony o wypłaty z systemu ubezpieczeń $\left(1-\tau_{t}\right) w_{t}^{j} l_{t}^{j}+A_{t}^{j}$. Identyczne wnioski otrzymuje się przy przyjęciu założenia, że wypłaty z ubezpieczeń $A_{t}^{\prime j}$ są opodatkowane i wypłacane w taki sposób, by wszystkie gospodarstwa otrzymywały jednakowe dochody z pracy powiększone o wypłaty ubezpieczeń, równe $\left(1-\tau_{t}\right)\left(w_{t}^{j} l_{t}^{j}+A_{t}^{\prime j}\right)$.

${ }^{4}$ Koszty niepełnego i nadmiernego wykorzystania kapitału można również uwzględnić poprzez przyjęcie wyższej stopy deprecjacji kapitału. Zastosowana przez Smetsa i Woutersa (2003) formuła liczenia kosztu ma jednak tę przewagę, że umożliwia jego wyrażenie w dobrach konsumpcyjnych (por. Greenwood, Hercowitz, Huffman, 1988; DeJong, Ingram, Whiteman, 2000). 
Dla przyjętej postaci funkcji użyteczności zachodzi zatem:

$$
E_{t}\left(\beta \frac{\varepsilon_{t+1}^{\text {pref }}}{\varepsilon_{t}^{\text {pref }}}\left(\frac{C_{t+1}^{j}-v_{t+1}}{C_{t}^{j}-v_{t}}\right)^{-\sigma_{c}} \frac{R_{t} P_{t}}{P_{t+1}}\right)=1 .
$$

Na rynku pracy występuje konkurencja monopolistyczna. Praca dostarczana przez poszczególne gospodarstwa domowe $\left(l_{t}^{j}\right)$ różni się od siebie, co powoduje, że gospodarstwa domowe mają na rynku pracy pewną siłę monopolistyczną. Na możliwości produkcyjne przedsiębiorstw wpływ ma kształtowanie się agregatowego indeksu zatrudnienia $\left(L_{t}\right)$, uzależnionego od czasu pracy poszczególnych gospodarstw domowych. Agregatowy indeks zatrudnienia w gospodarce określony jest przez funkcję Dixit-Stiglitza (1977):

$L_{t}=\left[\int_{0}^{1}\left(l_{t}^{j}\right)^{\frac{1}{1+\lambda_{w, t}}} d j\right]^{1+\lambda_{w, t}}$,

gdzie:

$$
\lambda_{w, t}>0
$$

Natomiast nominalną stawkę płac $\left(W_{t}\right)$ określa równanie:

$W_{t}=\left[\int_{0}^{1}\left(W_{t}^{j}\right)^{-\frac{1}{\lambda_{w, t}}} d j\right]^{-\lambda_{w, t}}$.

$\lambda_{w, t}$ określa wielkość narzutu na wynagrodzenia ${ }^{5}$. W modelu zakłada się, że narzut na wynagrodzenia może podlegać wahaniom. Kształtowanie się szoków dotyczących narzutu na wynagrodzenia określa równanie postaci:

$\lambda_{w, t}=\lambda_{w}+\zeta_{w, t}$,

gdzie:

$\lambda_{w}$ - parametr określający średnią wielkość narzutu na wynagrodzenia, $\zeta_{w, t} \sim N\left(0, \sigma_{\zeta, w}{ }^{2}\right)$.

Z równań (213)-(214) wynika, że popyt na pracę poszczególnego gospodarstwa domowego określa równanie:

$l_{t}^{j}=\left(\frac{W_{t}^{j}}{W_{t}}\right)^{-\left(\frac{1+\lambda_{w, t}}{\lambda_{w, t}}\right)} L_{t}$.

${ }^{5}$ Czyli nakładany przez gospodarstwa domowe narzut na wynagrodzenia ponad krańcową stopę substytucji, wynikający z ich siły monopolistycznej (por. Woodford, 2003). 
Alternatywnie, równania (213)-(214) można zapisać w postaci (por. np. Woodford, 2003; McCandless, 2008):

$L_{t}=\left[\int_{0}^{1}\left(l_{t}^{j}\right)^{\frac{\eta_{l, t}-1}{\eta_{l, t}}} d j\right]^{\frac{\eta_{l, t}}{\eta_{l, t}-1}}$

$W_{t}=\left[\int_{0}^{1}\left(W_{t}^{j}\right)^{1-\eta_{l, t}} d j\right]^{\frac{1}{1-\eta_{l, t}}}$,

gdzie $\eta_{l, t}$ oznacza elastyczność substytucji pracy dostarczanej przez poszczególne gospodarstwa domowe ${ }^{6}$, otrzymując:

$l_{t}^{j}=\left(\frac{W_{t}^{j}}{W_{t}}\right)^{-\eta_{l, t}} L_{t}$.

W modelu, zgodnie ze schematem Calvo (1983), w każdym okresie jedynie część płac jest optymalizowana. Prawdopodobieństwo, że w danym okresie gospodarstwo domowe będzie ustalać stawkę płac maksymalizującą poziom użyteczności jest stałe i nie zależy od tego, kiedy poprzednio gospodarstwo domowe dostosowywało poziom płac. Nie optymalizowane płace są częściowo indeksowane na podstawie kształtowania się inflacji w poprzednim okresie.

Uwzględniając, że w każdym okresie część gospodarstw domowych indeksuje stawkę płac, a część podejmuje decyzje optymalizacyjne, na podstawie równania (214) otrzymuje się następujący wzór określający poziom płac nominalnych w gospodarce:

$\left.W_{t}=\left(\xi_{w} W_{I N D, t}{ }^{-\frac{1}{\lambda_{w, t}}}+\left(1-\xi_{w}\right) W_{O P T, t}\right)^{-\frac{1}{\lambda_{w, t}}}\right)^{-\lambda_{w, t}}$,

gdzie:

$1-\xi_{w}-$ prawdopodobieństwo, że w danym okresie gospodarstwo domowe będzie optymalizowało poziom płac,

$W_{I N D, t}$ - poziom nominalnej stawki płac gospodarstw domowych ustalających płace na podstawie indeksacji,

${ }^{6}$ Pomiędzy elastycznością substytucji a narzutem na wynagrodzenia zachodzi zatem zależność: $1+\lambda_{w, t}=\frac{\eta_{l, t}}{\eta_{l, t}-1}$ (por. Woodford, 2011). 
$W_{O P T, t}$ - poziom nominalnej stawki płac gospodarstw domowych podejmujących decyzje optymalizacyjne.

Dla każdego gospodarstwa domowego, które nie optymalizuje w danym okresie stawki płac, kształtowanie się płacy nominalnej określane jest na podstawie indeksacji, przeprowadzanej w oparciu o przeszłą inflację, czyli:

$W_{I N D, t}^{j}=\left(\frac{P_{t-1}}{P_{t-2}}\right)^{\gamma_{w}} W_{t-1}^{j}$,

gdzie:

$W_{I N D, t}^{j}$ - nominalna stawka płac otrzymywana przez $j$-te gospodarstwo domowe, ustalana na podstawie indeksacji,

$\gamma_{w}-$ stopień indeksacji płac,

$\gamma_{w} \in<0,1>$.

Dla $\gamma_{w}=1$ zachodzi pełna indeksacja płac, natomiast dla $\gamma_{w}=0$ płace nie są indeksowane. Jak wynika z równania (221) indeksacja dotyczy płacy brutto. Kształtowanie się ustalanej na podstawie indeksacji płacy netto uzyskiwanej przez $j$-te gospodarstwo domowe określa zatem następujący wzór:

$N W_{I N D, t}^{j}=\frac{1-\tau_{t-1}}{1-\tau_{t}}\left(\frac{P_{t-1}}{P_{t-2}}\right)^{\gamma_{w}} N W_{t-1}^{j}$,

gdzie:

$N W_{t}^{j}$ - stawka płac netto otrzymywana przez $j$-te gospodarstwo domowe.

Natomiast w przypadku gospodarstw domowych, które w danym okresie optymalizują poziom wynagrodzeń, wysokość stawki płac określana jest w taki sposób, aby spełniony był następujący warunek dotyczący realnej płacy netto:

$$
\frac{N W_{O P T, t}^{j}}{P_{t}}=\frac{E_{t}\left(\sum_{i=0}^{\infty} \beta^{i} \xi_{w}^{i} l_{t+i}^{j}\left(-u_{l, t+i}\right)\right)}{E_{t}\left(\sum_{i=0}^{\infty} \beta^{i} \xi_{w}^{i}\left(\frac{P_{t}}{P_{t-1}} \frac{P_{t+i-1}}{P_{t+i}}\right)^{\gamma_{w}} \frac{l_{t+i}^{j} u_{c, t+i}}{1+\lambda_{w, t+i}}\right)},
$$

gdzie:

$$
u_{c, t}=\frac{\partial u_{t}}{\partial c_{t}}>0, u_{l, t}=\frac{\partial u_{t}}{\partial l_{t}}<0 .
$$

Płaca brutto ustalana przez gospodarstwa domowe podejmujące decyzje optymalizacyjne $\left(W_{O P T, t}^{j}\right)$ wynosi zatem: 


$$
W_{O P T, t}^{j}=\frac{P_{t} E_{t}\left(\sum_{i=0}^{\infty} \beta^{i} \xi_{w}^{i} l_{t+i}^{j}\left(-u_{l, t+i}\right)\right)}{\left(1-\tau_{t}\right) E_{t}\left(\sum_{i=0}^{\infty} \beta^{i} \xi_{w}^{i}\left(\frac{1+\pi_{t}}{1+\pi_{t+i}}\right)^{\gamma_{w}} \frac{l_{t+i}^{j} u_{c, t+i}}{1+\lambda_{w, t+i}}\right)} .
$$

W rezultacie, uwzględniając kształtowanie się indeksowanych oraz optymalizowanych stawek płac oraz równanie (220) otrzymuje się, że średnia stawka płac w całej gospodarce jest określona wzorem:

$W_{t}=\left(\xi_{w}\left(\left(1+\pi_{t-1}\right)^{\gamma_{w}} W_{t-1}\right)^{-\frac{1}{h_{w} t}}+\left(1-\xi_{w}\right)\left(\frac{\frac{P_{t}}{1-\tau_{t}} E_{t}\left(\sum_{i=0}^{\infty} \beta^{i} \xi_{w}^{i} l_{t+i}^{j}\left(-u_{l, t+i}\right)\right)}{E_{t}\left(\sum_{i=0}^{\infty} \beta^{i} \xi_{w}^{i}\left(\frac{1+\pi_{t}}{1+\pi_{t+i}}\right)^{\gamma_{w}} \frac{l_{t+i}^{j} u_{c, t+i}}{1+\lambda_{w, t+i}}\right)}\right)^{-\frac{1}{\lambda_{w, t}}}\right)^{-\lambda_{w, t}}$.

Uwzględniając, że przy założonej postaci funkcji użyteczności zachodzi:

$$
\begin{aligned}
& u_{l, t}=-\varepsilon_{t}^{l}\left(l_{t}^{j}\right)^{\sigma_{l}}, \\
& u_{c, t}=\varepsilon_{t}^{c}\left(C_{t}^{j}-v_{t}\right)^{-\sigma_{c}}
\end{aligned}
$$

otrzymuje się:

$$
\left.W_{t}=\left(\xi_{w}\left(\left(1+\pi_{t-1}\right)^{\gamma_{w}} W_{t-1}\right)^{-\frac{1}{\lambda_{w}}}+\left(1-\xi_{w}\right)\left(\frac{\frac{P_{t}}{1-\tau_{t}} E_{t}\left(\sum_{i=0}^{\infty} \beta^{i} \xi_{w}^{i} \varepsilon_{t}^{l}\left(l_{t+i}^{j}\right)^{1+\sigma_{l}}\right)}{E_{t}\left(\sum_{i=0}^{\infty} \frac{\left.\beta^{i} \xi_{w}^{i} l_{t+i}^{j} \varepsilon_{t+i}^{c}\left(\frac{1+\pi_{t}}{1+\pi_{t+i}}\right)^{\gamma_{w}}\right)}{\left(1+\lambda_{w, t+i}\right)\left(C_{t+i}^{j}-v_{t+i}\right)^{\sigma_{c}}}\right)}\right)^{-\frac{1}{\lambda_{w, t}}}\right)^{-\lambda_{w, t}}\right) .
$$


W modelu zakłada się, że zmiany w poziomie inwestycji wiążą się z dodatkowymi kosztami ${ }^{7}$. W rezultacie funkcja przyrostu inwestycji jest określona wzorem:

$$
k_{t}=(1-\delta) k_{t-1}+\left(1-S\left(\frac{\varepsilon_{t}^{I} I_{t}}{I_{t-1}}\right)\right) I_{t},
$$

gdzie:

$\varepsilon_{t}^{I}$ - szoki dotyczące poziomu kosztów związanych ze zmianami inwestycji. Funkcja ukazująca koszty związane ze zmianami poziomu inwestycji spełnia następujące warunki: $S(1)=0, S^{\prime}\left(\frac{\varepsilon_{t}^{I} I_{t}}{I_{t-1}}\right)<0$ dla $\frac{\varepsilon_{t}^{I} I_{t}}{I_{t-1}} \in(0,1), S^{\prime}\left(\frac{\varepsilon_{t}^{I} I_{t}}{I_{t-1}}\right)>0$ dla $\frac{\varepsilon_{t}^{I} I_{t}}{I_{t-1}}>1$. Natomiast szoki dotyczące poziomu kosztów związanych ze zmianami inwestycji określone są przez proces autoregresyjny postaci:

$$
\varepsilon_{t}^{I}=\rho_{\varepsilon, I} \varepsilon_{t-1}^{I}+\zeta_{I, t}, \zeta_{I, t} \sim N\left(0, \sigma_{\zeta, I}{ }^{2}\right), \rho_{\varepsilon, I} \in(0,1)
$$

Przy założonej, uwzględniającej koszty zmian poziomu inwestycji, postaci funkcji przyrostu kapitału oraz występowaniu opodatkowania oraz kosztów związanych z niepełnym lub nadmiernym stopniem wykorzystania kapitału (por. równanie (210)) otrzymuje się następujące warunki optymalizacji dotyczące kształtowania się wartości kapitału, poziomu inwestycji oraz stopy wykorzystania kapitału:

$Q_{t} S^{\prime}\left(\frac{\varepsilon_{t}^{I} I_{t}}{I_{t-1}}\right) \frac{\varepsilon_{t}^{I} I_{t}}{I_{t-1}}+\beta E_{t}\left(Q_{t+1} \frac{\varepsilon_{t+1}^{\text {pref }}}{\varepsilon_{t}^{\text {pref }}}\left(\frac{C_{t+1}^{j}-v_{t+1}}{C_{t}^{j}-v_{t}}\right)^{-\sigma_{c}} S^{\prime}\left(\frac{\varepsilon_{t+1}^{I} I_{t+1}}{I_{t}}\right)\left(\frac{\varepsilon_{t+1}^{I} I_{t+1}}{I_{t}}\right) \frac{I_{t+1}}{I_{t}}\right)=1$,

$$
\begin{aligned}
& \Psi^{\prime}\left(u_{K, t}\right)=r_{t}^{K}, \\
& Q_{t}=E_{t}\left(\beta \frac{\varepsilon_{t+1}^{\text {pref }}}{\varepsilon_{t}^{\text {pref }}}\left(\frac{C_{t+1}^{j}-v_{t+1}}{C_{t}^{j}-v_{t}}\right)^{-\sigma_{c}}\left(Q_{t+1}(1-\delta)+\left(1-\tau_{t}\right) u_{K, t} r_{t}^{K}-\Psi^{\prime}\left(u_{K, t}\right)\right)\right),
\end{aligned}
$$

gdzie:

$Q_{t}-$ wartość kapitału.

${ }^{7}$ Szerzej na temat kosztów dostosowania inwestycji por. np. Angeloni, Coenen i Smets (2003), Christiano, Eichenbaum i Evans (2005) oraz Milo i in. (2010). 
Jak wynika z równania (233) wartość kapitału uzależniona jest od jego przyszłej wartości oczekiwanej, przy uwzględnieniu deprecjacji kapitału oraz przychodów z kapitału po opodatkowaniü.

W modelu zakłada się, że występuje jedno dobro finalne, które jest produkowane $\mathrm{w}$ oparciu o kontinuum dóbr pośrednich, indeksowanych względem $i(i \in<0,1>)^{9}$. Dobra pośrednie są wytwarzane przez firmy działające $\mathrm{w}$ warunkach konkurencji monopolistycznej. Każde dobro pośrednie $i$ jest produkowane przez inną firmę. Dobro finalne jest wytwarzane w oparciu o dobra pośrednie przy wykorzystaniu następującej technologii:

$Y_{t}=\left[\int_{0}^{1} y_{t}(i)^{\frac{1}{1+\lambda_{p, t}}} d i\right]^{1+\lambda_{p, t}}$,

gdzie:

$\lambda_{p, t}-$ parametr określający wysokość narzutu ${ }^{10}$. postaci ${ }^{11}$ :

Parametr $\lambda_{p, t}$ ma charakter szoku stochastycznego, określonego przez proces $\lambda_{p, t}=\lambda_{p}+\zeta_{\lambda, p, t}, \zeta_{\lambda, p, t} \sim N\left(0, \sigma_{\lambda, p}{ }^{2}\right)$.

Na podstawie warunku dotyczącego minimalizacji kosztów produkcji dóbr finalnych otrzymuje się, że popyt na dobro pośrednie jest dany wzorem $^{12}$ :

$y_{t}(i)=\left(\frac{p_{t}(i)}{P_{t}}\right)^{-\frac{1+\lambda_{p, t}}{\lambda_{p, t}}} Y_{t}$,

${ }^{8}$ Pomniejszonych o koszty związane z niepełnym lub nadmiernym stopniem wykorzystania kapitału.

${ }^{9}$ Jak wspomniano w rozdziale drugim, w części modeli DSGE przyjmuje się alternatywne założenie, że przedsiębiorstwa działające w warunkach konkurencji monopolistycznej sprzedają gospodarstwom domowych różnorodne dobra finalne, a następnie gospodarstwa domowe agregują koszyk dóbr finalnych, cechujących się stałą elastycznością substytucji.

${ }^{10}$ Podobnie jak w przypadku wynagrodzeń, równanie (234) można w postaci określonej równaniem (109), w której poziom produkcji dobra finalnego jest uzależniony nie od kształtowania się narzutu, lecz od elastyczności substytucji dóbr pośrednich wykorzystywanych do produkcji dobra finalnego (por. np. Woodford, 2003; McCandless, 2008; Christiano, Eichenbaum, i Rebelo, 2009; Grabek, Kłos, Koloch, 2010). W rozdziale przyjęto jednak notację wykorzystującą wysokość narzutu, ze względu na fakt, że w modelu szoki stochastyczne dotyczą bezpośrednio wysokości narzutu, a nie kształtowania się elastyczności.

11 Jak wskazują Smets i Wouters (2003) określające wysokość narzutu zmiany $\lambda_{p, t}$ interpretowane mogą być jako szoki kosztowe oddziałujące na kształtowanie się inflacji.

${ }^{12}$ Im niższa wartość parametru $\lambda_{p, t}$ tym wyższa wartość bezwzględna elastyczności substytucji $\eta_{t}, \mathrm{tj} .: \eta_{t}=\frac{1+\lambda_{p, t}}{\lambda_{p, t}}$ (por. równanie (110)). 
a poziom ceny dobra finalnego określa równanie:

$P_{t}=\left[\int_{0}^{1} p_{t}(i)^{-\frac{1}{\lambda_{p, t}}} d i\right]^{-\lambda_{p, t}}$.

Dobra pośrednie są wytwarzane zgodnie z następującą funkcją produkcji:

$y_{t}(i)=z_{t}\left(u_{K, t} k_{t}(i)\right)^{\theta} L_{t}(i)^{1-\theta}-F C$,

gdzie:

$k_{t}(i)$ - kapitał wykorzystywany do produkcji $i$-tego dobra pośredniego,

$L_{t}(i)$ - zagregowany indeks zatrudnienia zaangażowany w produkcje $i$-tego dobra pośredniego,

$\theta \in(0,1)$.

Jak wynika z równania (238) szok dotyczący łącznej produktywności czynników produkcji czynników oddziałuje w taki sam sposób na produkcję każdego z dóbr pośrednich. Łączna produktywność czynników produkcji zmienia się zgodnie z procesem autoregresyjnym określonym równaniem (5).

Na podstawie warunku minimalizacji kosztów otrzymuje się:

$$
\frac{W_{t} L_{t}(i)}{r_{t}^{k} u_{K, t} k_{t}(i)}=\frac{1-\theta}{\theta} \text {. }
$$

Warunek ten jest taki sam dla każdego dobra pośredniego $i$. Relacja indeksu zatrudnienia do kapitału jest więc jednakowa dla każdego dobra pośredniego $i$, a w rezultacie także w skali całej gospodarki, czyli:

$$
\frac{k_{t}(i)}{L_{t}(i)}=\frac{k_{t}}{L_{t}} \text {. }
$$

Koszt krańcowy $\left(M C_{t}\right)$ jest określony wzorem postaci:

$M C_{t}=\frac{\left(r_{t}^{k}\right)^{\theta} W_{t}^{1-\theta}}{z_{t} \theta^{\theta}(1-\theta)^{1-\theta}}$.

Zatem koszt krańcowy, podobnie jak kształtowanie się relacji kapitału do pracy, jest taki sam dla każdego z dóbr pośrednich, a więc i dla całej gospodarki.

Zysk przedsiębiorstwa produkującego dobro pośrednie $\left(\Pi_{t}(i)\right)$, uwzględniając równanie (236), można zapisać w postaci: 
$\Pi_{t}(i)=\left(p_{t}(i)-M C_{t}\right)\left(\frac{p_{t}(i)}{P_{t}}\right)^{-\frac{1+\lambda_{p, t}}{\lambda_{p, t}}} Y_{t}-M C_{t} F C$.

Przedsiębiorstwo produkujące dobro pośrednie, działając $\mathrm{w}$ warunkach konkurencji monopolistycznej, ma wpływ na cenę dobra $p_{t}(i)$. W modelu zakłada się, że jedynie część firm ustala ceny optymalizujące zyski, a reszta firm dostosowuje ceny na podstawie wcześniejszej inflacji. Podobnie jak w przypadku płac przyjmuje się, że ceny ustalane są zgodnie ze schematem Calvo (1983). A zatem:

$\left.P_{t}=\left(\xi_{p} P_{I N D, t}{ }^{\frac{1}{\lambda_{p, t}}}+\left(1-\xi_{p}\right) P_{O P T, t}\right)^{-\frac{1}{\lambda_{p, t}}}\right)^{-\lambda_{p, t}}$,

gdzie $P_{I N D, t}$ oznacza cenę ustalaną przez firmy dokonujące indeksacji ${ }^{13}$.

Poszczególne firmy podejmujące decyzje na podstawie indeksacji ustalają ceny zgodnie z następującą formułą:

$p_{I N D, t}(i)=\left(\frac{P_{t-1}}{P_{t-2}}\right)^{\gamma_{P}} p_{t-1}(i)=\left(1+\pi_{t-1}\right)^{\gamma_{P}} p_{t-1}(i)$,

gdzie:

$p_{I N D, t}(i)$ - cena $i$-tego dobra pośredniego, ustalana na podstawie indeksacji,

$\gamma_{P}-$ stopień indeksacji cen,

$\gamma_{P} \in<0,1>$.

Przedsiębiorstwa podejmujące decyzje optymalizacyjne ustalają ceny maksymalizujące wartość oczekiwaną sumy zdyskontowanych zysków. Czynnik dyskontujący $\left(\rho_{t+k}^{\pi}\right)$ w tym przypadku przyjmuje postać:

$$
\rho_{t+k}^{\pi}=\beta^{k} \frac{u_{c, t+k}}{u_{c, t}} \frac{1}{P_{t+k}} .
$$

Dla założonej funkcji użyteczności zachodzi więc:

$\rho_{t+k}^{\pi}=\beta^{k} \frac{\varepsilon_{t+k}^{\text {pref }}}{\varepsilon_{t}^{\text {pref }}}\left(\frac{C_{t+k}-v_{t+k}}{C_{t}-v_{t}}\right)^{-\sigma_{c}} \frac{1}{P_{t+k}}$.

W rezultacie na podstawie równania (242) oraz równania (246) otrzymuje się, że przedsiębiorstwo maksymalizuje wartość oczekiwaną sumy zdyskontowanych zysków postaci:

13 Równanie (243) stanowi zatem bardziej ogólną wersję równania (119), tj. uwzględnia, że cena nie optymalizowana może w wyniku indeksacji różnić się od ceny z poprzedniego okresu, a także, że elastyczność substytucji może ulegać zmianom. 


$$
\begin{aligned}
& E_{t} \sum_{k=0}^{\infty} \rho_{t+k}^{\pi} \Pi_{t+k}(i)= \\
& =E_{t} \sum_{k=0}^{\infty} \beta^{k} \frac{\varepsilon_{t+k}^{\text {pref }}}{\varepsilon_{t}^{\text {pref }}}\left(\frac{C_{t+k}-v_{t+k}}{C_{t}-v_{t}}\right)^{-\sigma_{c}} \frac{1}{P_{t+k}}\left(\left(p_{t}(i)-M C_{t}\right)\left(\frac{p_{t}(i)}{P_{t}}\right)^{-\frac{1+\lambda_{p, t}}{\lambda_{p, t}}} Y_{t}-F C\right) .
\end{aligned}
$$

Przedsiębiorstwo, ustalając cenę maksymalizującą wartość oczekiwaną sumy zdyskontowanych zysków, bierze pod uwagę, że w przyszłości z prawdopodobieństwem $\xi_{p}$ będzie zmieniało poziomu cen na podstawie indeksacji. W rezultacie otrzymuje się następujący warunek optymalizacji:

$E_{t} \sum_{k=0}^{\infty} \beta^{k} \xi_{p}^{k} \frac{\varepsilon_{t+k}^{\text {pref }}}{\left(C_{t+k}-v_{t+k}\right)^{\sigma}} y_{t+k}(i)\left(\frac{P_{O P T, t}}{P_{t}}\left(\frac{1+\pi_{t}}{1+\pi_{t+k}}\right)^{\gamma_{P}}-\left(1+\lambda_{p, t+k}\right) m c_{t+k}\right)=0$,

gdzie $m c_{t}$ oznacza realny koszt krańcowy, czyli:

$m c_{t}=\frac{M C_{t}}{P_{t}}$.

Równanie agregatowego popytu, uwzględniając, że część wydatków związanych jest z kosztami niepełnego lub nadmiernego stopnia wykorzystania kapitału, przyjmuje postać:

$Y_{t}=C_{t}+I_{t}+\Psi\left(u_{K, t}\right) k_{t-1}+G_{t}$.

W modelu polityka fiskalna oddziałuje na gospodarkę poprzez szoki dotyczące wydatków rządowych $\left(G_{t}\right)$ oraz stopy podatkowej $\left(\tau_{t}\right)$. Stochastyczne zmiany wydatków rządowych oraz stopy podatkowej określają procesy autoregresyjne postaci:

$$
\begin{aligned}
& G_{t}=\left(1-\rho_{G}\right) \bar{G}+\rho_{G} G_{t-1}+\zeta_{G, t}, \\
& \tau_{t}=\left(1-\rho_{\tau}\right) \bar{\tau}+\rho_{\tau} \tau_{t-1}+\zeta_{\tau, t},
\end{aligned}
$$

gdzie:

$$
\begin{gathered}
\zeta_{G, t} \sim N\left(0,{\sigma_{\zeta, G}}^{2}\right), \bar{G}>0, \rho_{G} \in(0,1), \\
\zeta_{\tau, t} \sim N\left(0,{\sigma_{\zeta, \tau}}^{2}\right), \bar{\tau}>0, \rho_{\tau} \in(0,1) .
\end{gathered}
$$

W odpowiedzi na szoki fiskalne dotyczące wydatków rządowych oraz stopy podatkowej zryczałtowane podatki są dostosowane w taki sposób, by utrzymywać saldo budżetowe na stałym poziomie ${ }^{14}$.

14 Identyczne wyniki otrzymuje się, gdy dostosowywania dotyczą transferów. Podobnie jak w modelu w poprzednim rozdziale, z punktu widzenia państwa oraz gospodarstw domowych istotna jest bowiem jedynie różnica pomiędzy zryczałtowanymi podatkami a transferami. 
Równowaga na rynku dóbr i usług ma miejsce w sytuacji, gdy popyt określony równaniem (250) zrównuje się z podażą określoną równaniem (234), która z kolei wynika z produkcji poszczególnych dóbr pośrednich. Równowaga na rynku pracy występuje wtedy, gdy popyt na pracę producentów dóbr pośrednich zrównuje się z agregatowym indeksem podaży pracy, przy stawce płac ustalanej przez gospodarstwa domowe. $Z$ kolei równowaga na rynku kapitałowym ma miejsce, gdy popyt na kapitał zgłaszany przez producentów dóbr pośrednich zrównuje się z podażą kapitału dostarczanego przez gospodarstwa domowe.

Kształtowanie się nominalnej stopy procentowej wynika z prowadzonej polityki pieniężnej. Reguła polityki pieniężnej stanowi rozwinięcie reguły Taylora (1993) i przyjmuje postać:

$$
\begin{aligned}
& \tilde{r}_{t}^{n}=\rho_{r} \widetilde{r}_{t-1}^{n}+\left(1-\rho_{r}\right)\left(\bar{\pi}_{t}+r_{\pi}\left(\pi_{t-1}-\pi_{t}^{*}\right)+r_{Y}\left(\widetilde{Y}_{t}-\widetilde{Y}_{t}^{P}\right)\right)+ \\
& +r_{\Delta \pi}\left(\tilde{\pi}_{t}-\tilde{\pi}_{t-1}\right)+r_{\Delta Y}\left(\left(\widetilde{Y}_{t}-\widetilde{Y}_{t}^{P}\right)-\left(\widetilde{Y}_{t-1}-\widetilde{Y}_{t-1}^{P}\right)\right)+\zeta_{r, t},
\end{aligned}
$$

gdzie:

$\pi_{t}^{*}$ - poziom celu inflacyjnego określony przez proces autoregresyjny postaci:

$$
\pi_{t}^{*}=\rho_{\pi} \pi_{t-1}^{*}+\zeta_{\pi, t}, \zeta_{\pi, t} \sim N\left(0, \sigma_{\zeta, \pi}{ }^{2}\right), \rho_{\pi} \in(0,1)
$$

$\rho_{r}$ - parametr określający stopień wygładzenia stopy procentowej ${ }^{15}$,

$\zeta_{r, t}-$ szoki dotyczące stopy procentowej,

$\widetilde{r}_{t}^{n}, \widetilde{Y}_{t}, \widetilde{Y}_{t}^{P}, \widetilde{\pi}_{t}$ - odchylenia logarytmów odpowiednio nominalnej stopy procentowej, produkcji, produkcji potencjalnej oraz inflacji od poziomu steadystate $^{16}$,

$$
r_{\pi}, r_{Y}, r_{\Delta \pi}, r_{\Delta Y}>0, \rho_{r} \in(0,1), \zeta_{r, t} \sim N\left(0, \sigma_{\zeta, r}{ }^{2}\right) .
$$

A zatem władze monetarne reagują na odchylenia produkcji od poziomu potencjalnego, poziomu inflacji od celu inflacyjnego, a także na ostatnie zmiany dotyczące odchylenia produkcji od poziomu potencjalnego i inflacji ${ }^{17}$. Produkcja potencjalna definiowana jest jako poziom produkcji, dla której ceny i płace są elastyczne oraz nie występują szoki kosztowe.

15 Im wyższy parametr $\rho_{r}$ tym silniejsze wygładzenie stopy procentowej, a słabszy wpływ pozostałych zmiennych na bieżące kształtowanie się stopy procentowej.

${ }^{16}$ Przyjęto więc następujące oznaczenie: $\widetilde{x}_{t}=\ln x_{t}-\ln x^{*}$, gdzie $x^{*}$ oznacza poziom zmiennej w stanie ustalonym. W analogiczny sposób zdefiniowano pozostałe zmienne z tyldą w dalszej części rozdziału.

${ }_{17}$ Założony charakter polityki fiskalnej i monetarnej określa jednocześnie policy mix, czyli kombinację polityki fiskalnej i monetarnej. W modelu szoki fiskalne, wpływając na kształtowanie się produkcji i inflacji, pociągają za sobą zmiany stopy procentowej zgodnie z regułą Taylora. Zbadanie efektów szoków fiskalnych przy innych założeniach dotyczących policy mix, w tym w ramach analizy gospodarki otwartej, stanowi interesujące pole do dalszych badań. 
W modelu zakłada się, że cel inflacyjny może podlegać stochastycznym zmianom. Ponadto stopa procentowa podlega przejściowym szokom, określanych przez Smetsa i Woutersa jako szoki w polityce monetarnej.

Na podstawie przedstawionych założeń modelu, po log-linearyzacji zmiennych ${ }^{18}$, otrzymuje się, że dynamikę modelu określa następujący zestaw równań:

1. Równanie konsumpcji:

$$
\begin{aligned}
& \widetilde{C}_{t}=\frac{a_{v}}{1+a_{v}} \widetilde{C}_{t-1}+\frac{1}{1+a_{v}} E_{t}\left(\widetilde{C}_{t+1}\right)-\frac{1-a_{v}}{\left(1+a_{v}\right) \sigma_{c}}\left(\widetilde{R}_{t}-E_{t}\left(\widetilde{\pi}_{t+1}\right)\right)+ \\
& +\frac{1-a_{v}}{\left(1+a_{v}\right) \sigma_{c}}\left(\widetilde{\varepsilon}_{t}^{\text {pref }}-E_{t}\left(\widetilde{\varepsilon}_{t+1}^{\text {pref }}\right)\right) .
\end{aligned}
$$

2. Równanie inflacji:

$$
\begin{aligned}
& \tilde{\pi}_{t}=\frac{\beta}{1+\beta \gamma_{p}} E_{t}\left(\tilde{\pi}_{t+1}\right)+\frac{\gamma_{p}}{1+\beta \gamma_{p}} \tilde{\pi}_{t-1}+ \\
& +\frac{1}{1+\beta \gamma_{p}} \frac{\left(1-\beta \xi_{p}\right)\left(1-\xi_{p}\right)}{\xi_{p}}\left(\alpha \widetilde{r}_{t}^{k}+(1-\alpha) \widetilde{w}_{t}-\widetilde{z}_{t}+\zeta_{\lambda p, t}\right) .
\end{aligned}
$$

3. Równanie dotyczące płac ustalanych przez gospodarstwa domowe:

$$
\begin{aligned}
& \widetilde{w}_{t}=\frac{\beta}{1+\beta} E_{t}\left(\widetilde{w}_{t+1}\right)+\frac{1}{1+\beta} \widetilde{w}_{t-1}+\frac{\beta}{1+\beta} E_{t}\left(\widetilde{\pi}_{t+1}\right)-\frac{1+\beta \gamma_{w}}{1+\beta} \widetilde{\pi}_{t}+\frac{\gamma_{w}}{1+\beta} \widetilde{\pi}_{t-1}+ \\
& -\frac{1}{1+\beta} \frac{\left(1-\beta \xi_{w}\right)\left(1-\xi_{w}\right)}{\left(1+\frac{\left(1+\lambda_{w}\right) \sigma_{l}}{\lambda_{w}}\right) \xi_{w}}\left(\widetilde{w}_{t}-\widetilde{\tau}_{t}-\sigma_{l} \widetilde{L}_{t}-\frac{\sigma_{c}}{1-a_{v}}\left(\widetilde{C}_{t}-a_{v} \widetilde{C}_{t-1}\right)-\widetilde{\varepsilon}_{t}^{l}-\eta_{w, t}\right) .
\end{aligned}
$$

4. Równanie popytu na pracę:

$$
\widetilde{L}_{t}=-\widetilde{w}_{t}+\left(1+\frac{1}{\psi}\right) \widetilde{r}_{t}^{k}+\widetilde{k}_{t-1}
$$

gdzie:

$$
\psi=\frac{\Psi^{\prime \prime}(1)}{\Psi^{\prime}(1)},
$$

czyli $\psi$ stanowi elastyczność funkcji $\Psi$ względem stopnia wykorzystania możliwości wytwórczych.

18 Szerzej na temat log-linearyzacji zmiennych w modelach DSGE por. np. Dejong, Dave (2007); McCandless (2008). 
5. Równanie inwestycji:

$\widetilde{I}_{t}=\frac{1}{1+\beta} \widetilde{I}_{t-1}+\frac{\beta}{1+\beta} E_{t}\left(\widetilde{I}_{t+1}\right)+\frac{1}{\varphi_{S}(1+\beta)} \widetilde{Q}_{t}-E_{t} \frac{\beta}{1+\beta} \widetilde{\varepsilon}_{t+1}^{I}+\frac{1}{1+\beta} \widetilde{\varepsilon}_{t}^{I}$,

gdzie $\varphi_{S}=S^{\prime \prime}(1)$.

6. Równanie akumulacji kapitału:

$\widetilde{k}_{t}=(1-\delta) \widetilde{k}_{t-1}+\delta \widetilde{I}_{t-1}$.

7. Równanie określające wartość kapitału:

$$
\begin{aligned}
& \widetilde{Q}_{t}=-\left(\widetilde{R}_{t}-E_{t}\left(\widetilde{\pi}_{t+1}\right)\right)+\frac{1-\delta}{1-(1-\tau) \delta+(1-\tau) \bar{r}^{k}} E_{t}\left(\widetilde{Q}_{t+1}\right)+ \\
& +\frac{\bar{r}^{k}(1-\tau)}{1-(1-\tau) \delta+(1-\tau) \bar{r}^{k}} E_{t}\left(\widetilde{r}_{t+1}^{k}-\widetilde{\tau}_{t+1}\right)+\zeta_{Q, t},
\end{aligned}
$$

gdzie:

$\tau$ - poziom stopy podatkowej w stanie ustalonym,

$\zeta_{Q, t}-$ szok dotyczący wymaganej stopy zwrotu z inwestycji, $\zeta_{Q, t} \sim N\left(0, \sigma_{\zeta, Q}{ }^{2}\right)^{19}$,

$\bar{r}^{k}$ - wartość stopy zwrotu z wynajmu kapitału rzeczowego w stanie ustalonym, dla której zachodzi:

$\bar{r}^{k}=\frac{1}{\beta}-1+\delta$.

8. Równanie podaży:

$\widetilde{Y}_{t}=\left(1+F C_{y}\right)\left(\widetilde{z}_{t}+\theta \widetilde{k}_{t-1}+\theta \psi\left(\widetilde{r}_{t}^{k}\right)+(1-\theta) \widetilde{L}_{t}\right)$,

gdzie $F C_{y}$ stanowi miarę określająca wysokość kosztów stałych w relacji do wielkości produkcji:

$F C_{y}=\frac{F C}{Y}$,

gdzie $Y$ oznacza poziom produkcji w stanie ustalonym.

9. Równanie agregatowego popytu:

$\widetilde{Y}_{t}=\left(1-\delta k_{y}-g_{y}\right) \widetilde{C}_{t}+\delta k_{y} \widetilde{I}_{t}+g_{y} \widetilde{G}_{t}$,

19 Szok ten jako jedyny, jak podkreślają Smets i Wouters (2003), nie jest wyprowadzony z założeń dotyczących struktury gospodarki, lecz przyjęty ad hoc, w celu uwzględnienia wpływu zmian w wymaganej stopie zwrotu z inwestycji na dynamikę gospodarki. 
gdzie:

$g_{y}$ - udział wydatków rządowych w PKB w stanie ustalonym,

$k_{y}$ - współczynnik kapitałochłonności w stanie ustalonym.

10. Reguła polityki pieniężnej jest określona równaniem $(253)^{20}$.

W modelu wydatki rządowe oddziałują na gospodarkę poprzez wpływ na poziom agregatowego popytu (równanie (266)). Natomiast zmiany dotyczące stóp podatkowych przekładają się na wartość kapitału oraz poziom płac ustalanych przez gospodarstwa domowe (równania (262) oraz (257)). W wyniku sprzężeń zwrotnych pomiędzy poszczególnymi równaniami określającymi dynamikę modelu polityka fiskalna, wpływając na agregatowy popyt, poziom płac oraz wartość kapitału, oddziałuje również na pozostałe wielkości makroekonomiczne w analizowanej gospodarce.

\subsection{Metoda i wyniki estymacji parametrów}

Większość parametrów modelu, analogicznie jak w pracy Smetsa i Woutersa (2003), została oszacowana na podstawie estymacji bayesowskiej. Podejście bayesowskie jest obecnie jedną z coraz częściej stosowanych metod estymacji parametrów dynamicznych, stochastycznych modeli równowagi ogólnej (por. Adolfson, Linde, Villani 2007; Ruge-Murcia 2007; BrzozaBrzezina, Makarski, 2009; Gradzewicz, Makarski, 2009; Ferroni, 2010; Kuchta, 2012).

Wśród najważniejszych zalet tej metody wymienić należy (por. np. FernandezVillaverde, 2010; Kuchta, 2012):

- możliwość uwzględnienia informacji spoza próby o wartościach parametrów, w tym wyników badań mikroekonomicznych,

- niską wrażliwość wyników na błędy specyfikacji modelu ekonomicznego,

- porównywalność różnych modeli ekonomicznych.

Podejście bayesowskie opiera się na teoremacie Bayesa. W metodzie tej, w oparciu o informację a priori oraz aproksymację funkcji wiarygodności, znajduje się rozkłady a posterior $i^{21}$. Aproksymację funkcji wiarygodności przeprowadza się w wyniku zastosowaniu filtru Kalmana w oparciu o reprezentację

${ }^{20} \mathrm{~W}$ celu wyznaczenia produkcji potencjalnej zawartej w regule polityki pieniężnej wyznaczono dynamikę modelu na podstawie zmodyfikowanych równań 1-9, przy założeniu niewystępowania sztywności nominalnych cen i płac oraz szoków kosztowych.

${ }^{21}$ Metoda bayesowska jest szczegółowo opisana w pracach Osiewalskiego (1991) i (2001), Domańskiego i Pruskiej (2000) oraz Pipienia (2006). 
przestrzeni stanów. W pracy rozkład a posteriori wyznaczany jest przy wykorzystaniu algorytmu Metropolisa - Hastingsa (por. Metropolis i in., 1953; Hastings, 1970) ${ }^{22}$.

Kalibrację, podobnie jak w pracy Smetsa i Woutersa, zastosowano w przypadku tych parametrów, które uzależnione są przede wszystkim od wartości zmiennych w stanie ustalonym ${ }^{23}$. Elastyczność produkcji względem zatrudnienia oszacowano na poziomie 0,59 , analogicznie jak w rozdziale trzecim, na podstawie udziału kosztów pracy w PKB z uwzględnieniem składek na ubezpieczenia społeczne płaconych przez pracodawcę, kosztów pracy osób samozatrudnionych oraz dochodów z pracy w szarej strefie. W rezultacie otrzymano elastyczność produkcji względem kapitału $(\theta)$ wynoszącą 0,41 .

Poziom w stanie ustalonym udziału wydatków rządowych w PKB $\left(g_{y}\right)$, stopy podatkowej $(\tau)$ oraz kapitałochłonności $\left(k_{y}\right)$ przyjęto na podstawie średnich wielkości wymienionych zmiennych $\mathrm{w}$ gospodarce polskiej $\mathrm{w}$ latach $1995-2010^{24}$. Czynnik dyskontowy $(\beta)$ oraz stopę deprecjacji kapitału $(\delta)$ przyjęto, podobnie jak w modelu RBC analizowanym w poprzednim rozdziale, na standardowych poziomach zakładanych w literaturze, tj. odpowiednio 0,99 oraz 0,025 w skali kwartału.

$\mathrm{Na}$ podstawie kalibracji przyjęto również parametr określający marżę nakładaną na wynagrodzenia w stanie ustalonym $\left(\lambda_{w}\right)$, ze względu na fakt, że parametr ten nie jest identyfikowalny. Analogicznie jak w pracy Smetsa i Woutersa wysokość marży nakładanej na wynagrodzenia przyjęto na poziomie 0,5 .

Pozostałe parametry wyznaczono przy wykorzystaniu estymacji bayesowskiej. W estymacji uwzględniono następujące zmienne obserwowalne: PKB, zatrudnienie ${ }^{25}$, wynagrodzenia realne, spożycie indywidualne, nakłady brutto na środki trwałe, krótkookresowe 3-miesieczne stopy procentowe rynku pieniężnego oraz deflator $\mathrm{PKB}^{26}$. Wartości steady-state zmiennych obserwowalnych wyznaczono na podstawie filtra Christiano-Fitzgeralda (1999).

\footnotetext{
${ }^{22}$ Szerzej na temat wykorzystania algorytmu Metropolisa-Hastingsa w metodach DSGE por. np. Grabek, Kłos, Koloch (2010).

${ }^{23}$ Estymacja parametrów modelu opiera się na odchyleniach od steady-state, a zatem nie jest możliwe na jej podstawie wyznaczenie wartości parametrów uzależnionych od wartości zmiennych w stanie ustalonym.

${ }^{24}$ Dane Eurostatu i Ministerstwa Finansów.

${ }^{25} \mathrm{~W}$ ramach modelu popyt na pracę definiowany jest jako łączna liczba godzin pracy. Zmienna ta jest zmienną nieobserwowalną i dlatego w celu estymacji parametrów została zastąpiona ściśle z nią powiązaną zmienną obserwowalną, tj. poziomem zatrudnienia. Analogicznie jak u Smetsa i Woutersa (2003) założono, że w ramach fluktuacji makroekonomicznych poziom zatrudnienia dostosowuje się wolniej niż liczna godzin pracy i jedynie określony odsetek firm $\xi_{\text {emp }} \in(0,1)$ dostosowuje poziom zatrudnienia do nowych warunków na rynku pracy.

${ }^{26}$ Dane Eurostatu i GUS.
} 
Rozkłady a priori parametrów strukturalnych modelu oraz parametrów charakteryzujących szoki stochastyczne przyjęto analogicznie jak w pracy Smetsa i Woutersa. Rozkłady a priori parametrów strukturalnych modelu przedstawiono w tabeli 5.

Tabela 5. Rozkłady a priori parametrów strukturalnych

\begin{tabular}{|c|c|c|c|c|}
\hline Nazwa parametru & Symbol & $\begin{array}{c}\text { Typ } \\
\text { rozkładu }\end{array}$ & Średnia & $\begin{array}{l}\text { Odchylenie } \\
\text { standardowe }\end{array}$ \\
\hline $\begin{array}{l}\text { Odwrotność międzyokresowej } \\
\text { elastyczności substytucji }\end{array}$ & $\sigma_{c}$ & normalny & 1,5 & 0,375 \\
\hline Odwrotność elastyczności podaży pracy & $\sigma_{l}$ & normalny & 2 & 0,75 \\
\hline $\begin{array}{l}\text { Parametr określający siłę } \\
\text { przyzwyczajeń konsumpcyjnych }\end{array}$ & $a_{v}$ & beta & 0,7 & 0,1 \\
\hline $\begin{array}{l}\text { Prawdopodobieństwo zmiany poziomu } \\
\text { płac na podstawie indeksacji }\end{array}$ & $\xi_{w}$ & beta & 0,75 & 0,05 \\
\hline Parametr indeksacji dla płac & $\gamma_{w}$ & beta & 0,75 & 0,15 \\
\hline $\begin{array}{l}\text { Prawdopodobieństwo zmiany poziomu } \\
\text { cen dóbr pośrednich na podstawie } \\
\text { indeksacji }\end{array}$ & $\xi_{p}$ & beta & 0,75 & 0,05 \\
\hline $\begin{array}{l}\text { Parametr indeksacji dla cen dóbr } \\
\text { pośrednich }\end{array}$ & $\gamma_{p}$ & beta & 0,75 & 0,15 \\
\hline $\begin{array}{l}\text { Parametr dotyczący udziału kosztów } \\
\text { stałych w produkcie }\end{array}$ & $F C_{y}$ & normalny & 1,45 & 0,25 \\
\hline $\begin{array}{l}\text { Parametr określający koszty } \\
\text { dostosowania inwestycji }\end{array}$ & $\varphi_{S}$ & normalny & 4 & 1,5 \\
\hline $\begin{array}{l}\text { Parametr określający koszty zmiennego } \\
\text { stopnia wykorzystania kapitału }\end{array}$ & $\psi$ & normalny & 0,2 & 0,075 \\
\hline Parametr wygładzania w regule Taylora & $\rho_{r}$ & beta & 0,8 & 0,1 \\
\hline $\begin{array}{l}\text { Parametr reakcji w regule Taylora na } \\
\text { inflację }\end{array}$ & $r_{\pi}$ & normalny & 1,7 & 0,1 \\
\hline $\begin{array}{l}\text { Parametr reakcji w regule Taylora na } \\
\text { produkcję }\end{array}$ & $r_{Y}$ & normalny & 0,125 & 0,05 \\
\hline $\begin{array}{l}\text { Parametr reakcji w regule Taylora na } \\
\text { przyrost inflacji }\end{array}$ & $r_{\Delta \pi}$ & normalny & 0,3 & 0,1 \\
\hline $\begin{array}{l}\text { Parametr reakcji w regule Taylora na } \\
\text { przyrost produkcji }\end{array}$ & $r_{\Delta Y}$ & normalny & 0,0625 & 0,05 \\
\hline $\begin{array}{l}\text { Parametr określający dostosowania } \\
\text { zatrudnienia }\end{array}$ & $\xi_{\text {emp }}$ & beta & 0,5 & 0,15 \\
\hline
\end{tabular}

Źródło: Smets, Wouters (2003). 
W modelu występują dodatkowe parametry dotyczące szoków stochastycznych, związane z polityką podatkową, nie występujące w modelu Smetsa i Woutersa. W pracy założono, że rozkłady a priori parametrów określających charakter szoków dotyczących stóp podatkowych są analogiczne, jak w przypadku szoków dotyczących wydatków rządowych. Rozkłady parametrów a priori charakteryzujących szoki stochastyczne przedstawione zostały w tabeli 6 .

Tabela 6 . Rozkłady a priori parametrów charakteryzujących szoki stochastyczne

\begin{tabular}{|c|c|c|c|c|}
\hline Nazwa parametru & Symbol & $\begin{array}{c}\text { Typ } \\
\text { rozkładu }\end{array}$ & Średnia & $\begin{array}{c}\text { Odchylenie stan- } \\
\text { dardowe/stopnie } \\
\text { swobody* }\end{array}$ \\
\hline 1 & 2 & 3 & 4 & 5 \\
\hline $\begin{array}{l}\text { Szok dotyczący wydatków rządowych } \\
\text { - współczynnik autoregresji }\end{array}$ & $\rho_{G}$ & beta & 0,85 & 0,1 \\
\hline $\begin{array}{l}\text { Szok dotyczący wydatków rządowych } \\
\text { - odchylenie standardowe }\end{array}$ & $\sigma_{\zeta, G}$ & $\begin{array}{l}\text { odwrotny } \\
\text { gamma }\end{array}$ & 0,3 & 2 \\
\hline $\begin{array}{l}\text { Szok dotyczący stopy podatkowej } \\
\text { - współczynnik autoregresji }\end{array}$ & $\rho_{\tau}$ & beta & 0,85 & 0,1 \\
\hline $\begin{array}{l}\text { Szok dotyczący stopy podatkowej } \\
\text { - odchylenie standardowe }\end{array}$ & $\sigma_{\zeta, \tau}$ & $\begin{array}{l}\text { odwrotny } \\
\text { gamma }\end{array}$ & 0,3 & 2 \\
\hline $\begin{array}{l}\text { Szok dotyczący preferencji } \\
\text { - współczynnik autoregresji }\end{array}$ & $\rho_{\varepsilon, p r e f}$ & beta & 0,85 & 0,1 \\
\hline $\begin{array}{l}\text { Szok dotyczący preferencji } \\
\text { - odchylenie standardowe }\end{array}$ & $\sigma_{\zeta, p r e f}$ & $\begin{array}{l}\text { odwrotny } \\
\text { gamma }\end{array}$ & 0,2 & 2 \\
\hline $\begin{array}{l}\text { Szok dotyczący podaży pracy } \\
\text { - współczynnik autoregresji }\end{array}$ & $\rho_{\varepsilon, l}$ & beta & 0,85 & 0,1 \\
\hline $\begin{array}{l}\text { Szok dotyczący podaży pracy } \\
\text { - odchylenie standardowe }\end{array}$ & $\sigma_{\zeta, l}$ & $\begin{array}{l}\text { odwrotny } \\
\text { gamma }\end{array}$ & 1 & 2 \\
\hline $\begin{array}{l}\text { Szok dotyczący narzutu na płace } \\
\text { - odchylenie standardowe }\end{array}$ & $\sigma_{\zeta, w}$ & $\begin{array}{l}\text { odwrotny } \\
\text { gamma }\end{array}$ & 0,25 & 2 \\
\hline $\begin{array}{l}\text { Szok dotyczący narzutu na ceny } \\
\text { - odchylenie standardowe }\end{array}$ & $\sigma_{\zeta, p}$ & $\begin{array}{l}\text { odwrotny } \\
\text { gamma }\end{array}$ & 0,15 & 2 \\
\hline $\begin{array}{l}\text { Szok dotyczący inwestycji } \\
\text { - współczynnik regresji }\end{array}$ & $\rho_{\varepsilon, I}$ & beta & 0,85 & 0,1 \\
\hline $\begin{array}{l}\text { Szok dotyczący inwestycji } \\
\text { - odchylenie standardowe }\end{array}$ & $\sigma_{\zeta, I}$ & $\begin{array}{l}\text { odwrotny } \\
\text { gamma }\end{array}$ & 0,1 & 2 \\
\hline $\begin{array}{l}\text { Szok dotyczący wymaganej stopy zwrotu } \\
\text { - odchylenie standardowe }\end{array}$ & $\sigma_{\zeta, Q}$ & $\begin{array}{l}\text { odwrotny } \\
\text { gamma }\end{array}$ & 0,4 & 2 \\
\hline $\begin{array}{l}\text { Szok technologiczny } \\
\text { - współczynnik autoregresji }\end{array}$ & $\rho_{z}$ & beta & 0,85 & 0,1 \\
\hline
\end{tabular}


Tabela 6. (cd.)

\begin{tabular}{|l|c|c|c|c|}
\hline \multicolumn{1}{|c|}{1} & 2 & 3 & 4 & 5 \\
\hline $\begin{array}{l}\text { Szok technologiczny } \\
\text { - odchylenie standardowe }\end{array}$ & $\sigma_{\varepsilon, z}$ & $\begin{array}{c}\text { odwrotny } \\
\text { gamma }\end{array}$ & 0,4 & 2 \\
\hline $\begin{array}{l}\text { Szok dotyczący celu inflacyjnego } \\
\text { - współczynnik autoregresji }\end{array}$ & $\rho_{\pi}$ & beta & 0,85 & 0,1 \\
\hline $\begin{array}{l}\text { Szok dotyczący celu inflacyjnego } \\
\text { - odchylenie standardowe }\end{array}$ & $\sigma_{\zeta, \pi}$ & $\begin{array}{c}\text { odwrotny } \\
\text { gamma }\end{array}$ & 0,02 & 2 \\
\hline $\begin{array}{l}\text { Szok dotyczący stopy procentowej } \\
\text { - odchylenie standardowe }\end{array}$ & $\sigma_{\zeta, r}$ & $\begin{array}{c}\text { odwrotny } \\
\text { gamma }\end{array}$ & 0,1 & 2 \\
\hline
\end{tabular}

*Odchylenie standardowe dla rozkładu beta, stopnie swobody dla odwrotnego rozkładu gamma. Źródło: Smets, Wouters (2003) oraz opracowanie własne.

Oszacowania a posteriori wykonano na podstawie danych kwartalnych Eurostatu oraz GUS z lat 1995-2010. Estymacji parametrów modelu dokonano w oparciu o oprogramowanie Dynare. Uzyskane oceny średnich z rozkładów a posteriori zawarto $\mathrm{w}$ tabeli 7 oraz 8 .

Tabela 7. Oszacowania średnich z rozkładów a posteriori parametrów strukturalnych

\begin{tabular}{|l|c|c|c|c|}
\hline \multicolumn{1}{|c|}{ Nazwa szacowanego parametru } & Symbol & $\begin{array}{c}\text { Ocena } \\
\text { średniej }\end{array}$ & $\begin{array}{c}\text { Dolna granica } \\
\text { przedziału } \\
\text { ufności (5\%) }\end{array}$ & $\begin{array}{c}\text { Górna granica } \\
\text { przedziału } \\
\text { ufności (95\%) }\end{array}$ \\
\hline \multicolumn{1}{|c|}{$\begin{array}{l}\text { Odwrotność międzyokresowej } \\
\text { elastyczności substytucji }\end{array}$} & $\sigma_{c}$ & 2,063 & 2,051 & 5 \\
\hline $\begin{array}{l}\text { Odwrotność elastyczności podaży } \\
\text { pracy }\end{array}$ & $\sigma_{l}$ & 3,185 & 3,091 & 3,076 \\
\hline $\begin{array}{l}\text { Parametr określający siłę } \\
\text { przyzwyczajeń konsumpcyjnych }\end{array}$ & $a_{v}$ & 0,408 & 0,404 & 0,412 \\
\hline $\begin{array}{l}\text { Prawdopodobieństwo zmiany poziomu } \\
\text { płac na podstawie indeksacji }\end{array}$ & $\xi_{w}$ & 0,441 & 0,432 & 0,451 \\
\hline Parametr indeksacji dla płac & $\gamma_{w}$ & 0,513 & 0,505 & 0,519 \\
\hline $\begin{array}{l}\text { Prawdopodobieństwo zmiany poziomu } \\
\text { cen dóbr pośrednich na podstawie } \\
\text { indeksacji }\end{array}$ & $\xi_{p}$ & 0,524 & 0,519 & 0,531 \\
\hline $\begin{array}{l}\text { Parametr indeksacji dla cen dóbr } \\
\text { pośrednich }\end{array}$ & $\gamma_{p}$ & 0,503 & 0,494 & 0,515 \\
\hline $\begin{array}{l}\text { Parametr dotyczący udziału kosztów } \\
\text { stałych w produkcie }\end{array}$ & $F C_{y}$ & 1,595 & 1,559 & 1,622 \\
\hline
\end{tabular}


Tabela 7. (cd.)

\begin{tabular}{|l|c|c|c|c|}
\hline \multicolumn{1}{|c|}{1} & 2 & 3 & 4 & 5 \\
\hline $\begin{array}{l}\text { Parametr określający koszty } \\
\text { dostosowania inwestycji }\end{array}$ & $\varphi_{S}$ & 4,916 & 4,734 & 5,093 \\
\hline $\begin{array}{l}\text { Parametr określający koszty zmiennego } \\
\text { stopnia wykorzystania kapitału }\end{array}$ & $\psi$ & 0,303 & 0,298 & 0,307 \\
\hline Parametr wygładzania w regule Taylora & $\rho_{r}$ & 0,745 & 0,733 & 0,757 \\
\hline $\begin{array}{l}\text { Parametr reakcji w regule Taylora na } \\
\text { inflację }\end{array}$ & $r_{\pi}$ & 1,901 & 1,894 & 1,909 \\
\hline $\begin{array}{l}\text { Parametr reakcji w regule Taylora na } \\
\text { produkcję }\end{array}$ & $r_{Y}$ & 0,155 & 0,149 & 0,160 \\
\hline $\begin{array}{l}\text { Parametr reakcji w regule Taylora na } \\
\text { przyrost inflacji }\end{array}$ & $r_{\Delta \pi}$ & 0,400 & 0,398 & 0,402 \\
\hline $\begin{array}{l}\text { Parametr reakcji w regule Taylora na } \\
\text { przyrost produkcji }\end{array}$ & $r_{\Delta Y}$ & 0,306 & 0,302 & 0,310 \\
\hline $\begin{array}{l}\text { Parametr określający dostosowania } \\
\text { zatrudnienia }\end{array}$ & $\xi_{e m p}$ & 0,706 & 0,693 & 0,718 \\
\hline
\end{tabular}

Źródło: opracowanie własne na podstawie danych Eurostatu i GUS.

Tabela 8 . Oceny średnich z rozkładów a posteriori parametrów charakteryzujących szoki stochastyczne

\begin{tabular}{|l|c|c|c|c|}
\hline \multicolumn{1}{|c|}{ Nazwa szacowanego parametru } & Symbol & $\begin{array}{c}\text { Ocena } \\
\text { średniej }\end{array}$ & $\begin{array}{c}\text { Dolna granica } \\
\text { przedziału } \\
\text { ufności (5\%) }\end{array}$ & $\begin{array}{c}\text { Górna granica } \\
\text { przedziału } \\
\text { ufności (95\%) }\end{array}$ \\
\hline \multicolumn{1}{|c|}{ (1 } & 2 & 3 & 4 & 5 \\
\hline $\begin{array}{l}\text { Szok dotyczący wydatków rządowych } \\
\text { - współczynnik autoregresji }\end{array}$ & $\rho_{G}$ & 0,539 & 0,528 & 0,549 \\
\hline $\begin{array}{l}\text { Szok dotyczący wydatków rządowych } \\
\text { - odchylenie standardowe }\end{array}$ & $\sigma_{\zeta, G}$ & 0,699 & 0,698 & 0,700 \\
\hline $\begin{array}{l}\text { Szok dotyczący stopy podatkowej } \\
\text { - współczynnik autoregresji }\end{array}$ & $\rho_{\tau}$ & 0,523 & 0,517 & 0,530 \\
\hline $\begin{array}{l}\text { Szok dotyczący stopy podatkowej } \\
\text { - odchylenie standardowe }\end{array}$ & $\sigma_{\zeta, \tau}$ & 0,692 & 0,681 & 0,700 \\
\hline $\begin{array}{l}\text { Szok dotyczący preferencji } \\
\text { - współczynnik autoregresji }\end{array}$ & $\rho_{\varepsilon, p r e f}$ & 0,494 & 0,490 & 0,498 \\
\hline $\begin{array}{l}\text { Szok dotyczący preferencji } \\
\text { - odchylenie standardowe }\end{array}$ & $\sigma_{\zeta, p r e f}$ & 0,697 & 0,663 & 0,700 \\
\hline $\begin{array}{l}\text { Szok dotyczący podaży pracy } \\
\text { - współczynnik autoregresji }\end{array}$ & $\rho_{\varepsilon, l}$ & 0,463 & 0,453 & 0,474 \\
\hline $\begin{array}{l}\text { Szok dotyczący podaży pracy } \\
\text { - odchylenie standardowe }\end{array}$ & $\sigma_{\zeta, l}$ & 5,526 & 5,364 & 5,670 \\
\hline
\end{tabular}


Tabela 8. (cd.)

\begin{tabular}{|l|c|c|c|c|}
\hline \multicolumn{1}{|c|}{1} & 2 & 3 & 4 & 5 \\
\hline $\begin{array}{l}\text { Szok dotyczący narzutu na płace } \\
\text { - odchylenie standardowe }\end{array}$ & $\sigma_{\zeta, w}$ & 0,598 & 0,596 & 0,600 \\
\hline $\begin{array}{l}\text { Szok dotyczący narzutu na ceny } \\
\text { - odchylenie standardowe }\end{array}$ & $\sigma_{\zeta, p}$ & 0,448 & 0,445 & 0,450 \\
\hline $\begin{array}{l}\text { Szok dotyczący inwestycji } \\
\text { - współczynnik regresji }\end{array}$ & $\rho_{\varepsilon, I}$ & 0,506 & 0,501 & 0,508 \\
\hline $\begin{array}{l}\text { Szok dotyczący inwestycji } \\
\text { - odchylenie standardowe }\end{array}$ & $\sigma_{\zeta, I}$ & 0,183 & 0,162 & 0,200 \\
\hline $\begin{array}{l}\text { Szok dotyczący wymaganej stopy zwrotu } \\
\text { - odchylenie standardowe }\end{array}$ & $\sigma_{\zeta, Q}$ & 1,016 & 0,964 & 1,070 \\
\hline $\begin{array}{l}\text { Szok technologiczny } \\
\text { - współczynnik autoregresji }\end{array}$ & $\rho_{z}$ & 0.536 & 0,527 & 0,543 \\
\hline $\begin{array}{l}\text { Szok technologiczny } \\
\text { - odchylenie standardowe }\end{array}$ & $\sigma_{\varepsilon, z}$ & 0,893 & 0,885 & 0,900 \\
\hline $\begin{array}{l}\text { Szok dotyczący celu inflacyjnego } \\
\text { - współczynnik autoregresji }\end{array}$ & $\rho_{\pi}$ & 0,519 & 0,512 & 0,525 \\
\hline $\begin{array}{l}\text { Szok dotyczący celu inflacyjnego } \\
\text { - odchylenie standardowe }\end{array}$ & $\sigma_{\zeta, \pi}$ & 0,020 & 0,010 & 0,030 \\
\hline $\begin{array}{l}\text { Szok dotyczący stopy procentowej } \\
\text { - odchylenie standardowe }\end{array}$ & $\sigma_{\zeta, R}$ & 0,199 & 0,197 & 0,200 \\
\hline
\end{tabular}

Źródło: opracowanie własne na podstawie danych Eurostatu i GUS.

Porównując oszacowania parametrów strukturalnych analizowanego modelu z innymi oszacowaniami parametrów estymowanych modeli nowokeynesistowskich dla gospodarki polskiej zaobserwować można, że w wielu przypadkach oszacowania parametrów różnią się od siebie w sposób istotny (por. Grabek, Kłos i Utzig-Lenarczyk 2007; Kolasa, 2008; Gradzewicz, Makarski, 2009; Grabek, Kłos, Koloch, 2010; Kuchta, 2012). Przy czym jak wskazuje Kuchta (2012), pełna porównywalność parametrów wszystkich estymowanych modeli DSGE dla gospodarki polskiej nie jest możliwa, ze względu na inną strukturę, m.in. modeli gospodarki otwartej oraz gospodarki zamkniętej. Ponadto poszczególne opracowania różnią się od siebie badanym okresem, na podstawie którego dokonano estymacji.

\subsection{Skutki zwiększenia wydatków rządowych w sytuacji występowania sztywności nominalnych}

W modelu występuje 11 źródeł szoków, w tym 2 dotyczące polityki fiskalnej:

- szoki dotyczące wydatków rządowych,

- szoki dotyczące stopy podatkowej. 
W pierwszej kolejności poddano analizie oddziaływanie polityki fiskalnej polegającej na kształtowaniu wydatków rządowych, a następnie zbadano skutki zmian stawki podatkowej.
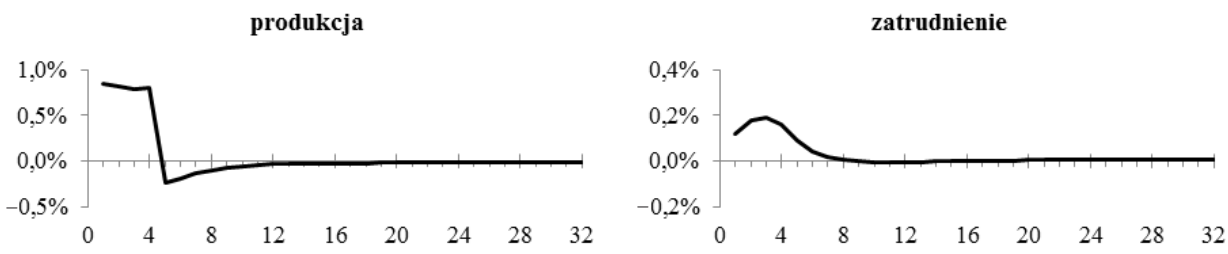

kapital

inwestycje
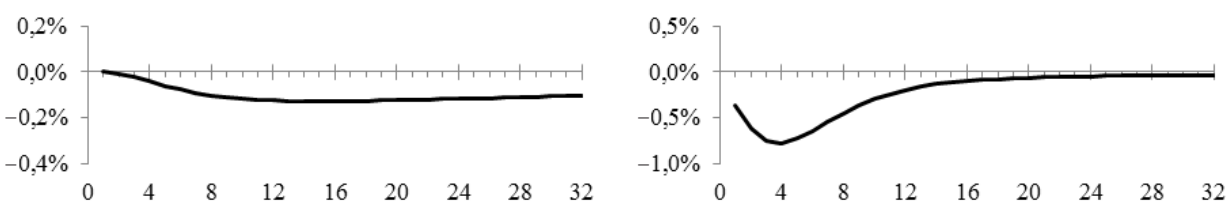

konsumpcja

inflacja
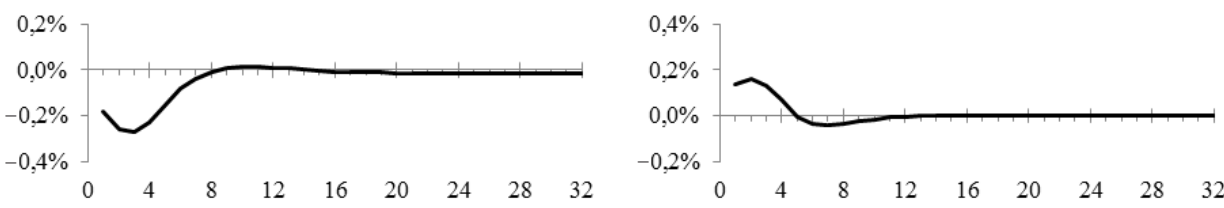

stawka plac

stopa procentowa
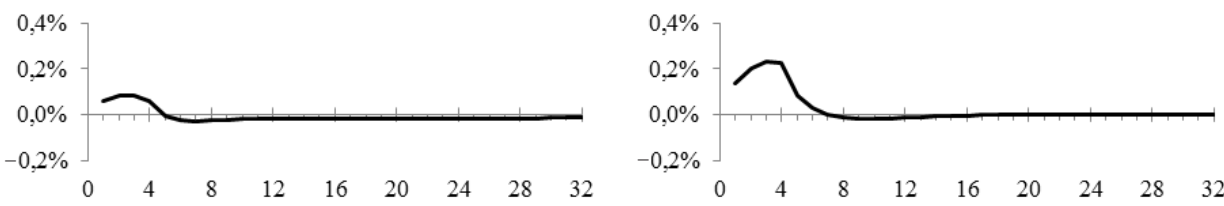

Rysunek 7. Oddziaływanie przejściowego, trwającego jeden rok, zwiększenia wydatków rządowych o 1\% PKB na procentowe odchylenie poszczególnych zmiennych od poziomu bazowego (dane kwartalne)

Źródło: opracowanie własne na podstawie danych Eurostatu, GUS i Ministerstwa Finansów

W modelu zmiany wydatków rządowych oddziałują na gospodarkę poprzez równanie agregatowego popytu. Na rysunku 7 ukazano wynikające z modelu oddziaływanie szoku w polityce fiskalnej, polegającego na trwającym 1 rok podwyższeniu wydatków rządowych sfinansowanych wyższymi podatkami niezależnymi od dochodu ${ }^{27}$. Analiza opiera się na danych kwartalnych, zatem jeden okres

${ }^{27} \mathrm{~W}$ rozdziale, w celu większej czytelności wyników oraz ich porównywalności z rezultatami przedstawionymi w rozdziale trzecim, przedstawiono estymacje punktowe. Zastosowanie metody 
oznacza kwartał. W modelu, w odróżnieniu od modelu RBC, zmienne nominalne oddziałują na procesy realne, tak więc oprócz zmiennych realnych uwzględniono również zmienne nominalne - inflację oraz stawkę płac i stopę procentową.

$\mathrm{Z}$ modelu wynika, że podniesienie wydatków rządowych o $1 \%$ PKB prowadzi od przejściowego wzrostu produkcji o ok. 0,8\%. Uzyskany mnożnik wydatków rządowych jest więc znacznie wyższy niż w przypadku modelu realnego cyklu koniunkturalnego.

Na wzrost produkcji wynikający ze zwiększenia wydatków rządowych wpływają zarówno czynniki podażowe, związane z negatywnym efektem majątkowym, jak i popytowe, będące skutkiem oddziaływania agregatowego popytu na poziom produkcji w warunkach sztywności nominalnych. $Z$ jednej strony negatywny efekt majątkowy, podobnie jak w modelu RBC, zwiększa podaż pracy. Wyższe wydatki rządowe stanowią bowiem drenaż zasobów z gospodarki i ograniczają poziom konsumpcji i czasu wolnego, a więc wzrost podaży pracy. $Z$ drugiej strony wzrost wydatków rządowych prowadzi do wzrostu agregatowego popytu. Ze względu na sztywności nominalne niektóre firmy nie reagują na wzrost popytu dostosowaniem cen, tylko dodatkowo zwiększoną produkcją. W rezultacie wzrost agregatowego popytu prowadzi do zwiększenia się popytu na pracę.

W wyniku wzrostu agregatowego popytu zwiększeniu ulega inflacja oraz poziom stopy procentowej. Zmiany stopy procentowej oddziałują z kolei na poziom konsumpcji prywatnej. W rezultacie, na skutek zwiększenia wydatków rządowych konsumpcja, podobnie jak w modelu RBC, ulega zmniejszeniu. Wyższe stopy procentowe zachęcają do ograniczenia konsumpcji obecnej na rzecz konsumpcji przyszłej. Występuje więc efekt wypychania konsumpcji przez wydatki rządowe. Wzrost agregatowego popytu przyczynia się jednak w pewnym stopniu do wzrostu produkcji, w wyniku czego efekt wypychania w mniejszym stopniu oddziałuje na kształtowanie się konsumpcji niż ma to miejsce w podażowym modelu RBC. Również inwestycje ulegają ograniczeniu. Spadek inwestycji jest przy tym relatywnie silniejszy niż w przypadku konsumpcji prywatnej. Jednocześnie ograniczenie inwestycji przyczynia się do częściowego wygładzenia wahań konsumpcji.

Porównując wyniki symulacji z rezultatami Smetsa i Woutersa (2003) zaobserwować można, że w obydwu przypadkach mnożniki wydatków rządowych są niższe od jedności, przy czym krótkookresowy wpływ zwiększenia wydatków rządowych jest w Polsce silniejszy niż w krajach strefy euro ${ }^{28}$. Wniosek ten po-

\footnotetext{
bayesowskiej umożliwia również generowanie funkcji reakcji na impuls zawierających przedziały ufności. Zarówno w przypadku szoków dotyczących wydatków rządowych, jak i analizowanych w dalszej części rozdziału szoków podatkowych, przedziały ufności ukazują, że wszystkie analizowane zmienne w sposób statystycznie istotny reagują na zmiany fiskalne.

${ }^{28}$ Wyniki symulacji przeprowadzone przez Smetsa i Woutersa (2003) na podstawie danych dla krajów strefy euro wskazują bowiem, że ekspansywna polityka fiskalna w istotny sposób wypycha inwestycje i konsumpcję prywatną, w wyniku czego mnożnik wydatków rządowych jest znacznie niższy od jedności.
} 
twierdzają również wyniki, które na podstawie modeli DSGE dla strefy euro otrzymali Coenen i Straub (2005) oraz Ratto, Roeger i in't Veld (2008) ${ }^{29}$. Jak wskazuje Wieland i in. (2012) również dla gospodarki amerykańskiej, opierając się na modelu Smetsa i Woutersa, otrzymuje się mnożnik wydatków rządowych niższy od jedności ${ }^{30}$. Dla gospodarki amerykańskiej nie przekraczający jedności mnożnik wydatków rządowych generuje również nowokeynesistowski model Levina, Wielanda i Williamsa $(2003)^{31}$.

$\mathrm{Z}$ opartego na modelu nowokeynesistowskim badania Caraianiego (2010) dotyczącego krajów Europy Środkowej wynika, że siła oddziaływania polityki fiskalnej na kształtowanie się PKB jest w gospodarce polskiej podobna jak w Czechach. Ekspansywna polityka fiskalna silniej niż w Polsce oddziałuje na kształtowanie się produkcji w Rumunii, natomiast słabiej - na Węgrzech ${ }^{32}$.

Grabek, Kłos i Utzig-Lenarczyk (2007) na podstawie nowokeynesistowskiego modelu SOE dla gospodarki polskiej otrzymali, że przejściowe zwiększenie wydatków rządowych o $1 \%$ PKB powoduje relatywnie słabszy wzrost produkcji, wynoszący ok. $0,6 \%$. Jak wskazują wymienieni autorzy, niewielka siła wpływu polityki fiskalnej wynikać może ze sposobu, w jaki w modelu SOE jest specyfikowany blok fiskalny ${ }^{33}$. Oddziaływanie wydatków rządowych na PKB wynikające $\mathrm{z}$ analizowanego $\mathrm{w}$ niniejszym rozdziale modelu jest natomiast zbliżone do rezultatów otrzymanych na podstawie modelu nowokeynesistowskiego Bukowskiego i in. (2005) ${ }^{34}$. Zgodnie w szacunkami przywołanych autorów, na

${ }^{29}$ Coenen i Straub (2005) uzyskali mnożnik wydatków rządowych na poziomie 0,68 (sposób wyliczenia ww. mnożnika por. Hall, 2009), natomiast Ratto, Roeger i in't Veld, (2008) - wynoszący 0,6.

${ }^{30}$ Wieland i in. (2012) na podstawie modelu Smetsa i Woutersa estymowanego na danych amerykańskich uzyskali mnożnik wydatków rządowych wynoszący ok. 0,4.

${ }^{31}$ W przypadku modelu Levina, Wielanda i Williamsa (2003) mnożnik wydatków rządowych kształtuje się na poziomie ok. 0,9 (por. Wieland i in., 2012). Jednocześnie jednak, jak wskazują Eggertsson (2008), Christiano, Eichenbaum, i Rebelo (2009) oraz Woodford (2011), jeśli stopy procentowe zbliżają się do granicy zerowego oprocentowania, wówczas na podstawie modeli nowokeynesistowskich uwzględniających limit zerowych stóp procentowych uzyskuje się mnożniki wydatków rządowych wyższe od jedności. Ponadto wyższe od jedności mnożniki wydatków rządowych generują modele, w których założony jest wysoki poziom sztywności cen (por. Hall, 2009) oraz duży odsetek gospodarstw niericardiańskich (por. Gali, Lopez-Salido, Valles, 2007; Eggertson, Krugman, 2012). Sytuacje takie występują w większym stopniu w krajach dotkniętych kryzysem gospodarczym (por. Blanchard, Leigh, 2013).

${ }^{32}$ Dla Polski oraz Czech Caraiani (2010) otrzymał mnożnik wydatków rządowych wynoszący ok. 0,7, dla Węgier - 0,5, natomiast dla Rumunii - pow. 1,5.

${ }^{33} \mathrm{~W}$ modelu SOE zmienne fiskalne pochodzą z odrębnie estymowanego modelu SVAR (por. Grabek, Kłos i Utzig-Lenarczyk, 2007). Warto również zaznaczyć, że wyznaczanie mnożnika wydatków rządowych bezpośrednio z popytowego wzoru na mnożnik generuje z kolei oszacowania wyższe od jedności (por. Łaski, Osiatyński i Zięba, 2010).

${ }^{34}$ Bukowski i in. (2005) przedstawiają model RBC oraz model nowokeynesistowski, stąd odniesienie do uzyskanych przez nich wyników zawarto zarówno w poprzednim, jak i w niniejszym rozdziale. 
skutek przejściowego zwiększenia wydatków rządowych o 1\% PKB początkowo produkcja ulega podwyższeniu o ok $1 \%$, a następnie stopniowo powraca do poziomu wyjściowego. Istotne różnice pomiędzy oszacowaniami Bukowskiego $\mathrm{i}$ in. a symulacjami ukazanymi na rysunku 7 dotyczą natomiast kierunku oddziaływania wydatków rządowych na inwestycje. Z przeprowadzonych przez Bukowskiego $i$ in. symulacji wynika bowiem, że wzrost wydatków rządowych o $1 \%$ PKB finansowany spadkiem zryczałtowanych transferó $\mathrm{w}^{35}$ powoduje przejściowy wzrost inwestycji o ok. $0,4 \%$. Z drugiej strony, wynikające z przedstawionych na rysunku 7 symulacji wnioski dotyczące charakteru oddziaływania wydatków rządowych na inwestycje są zgodne w wynikami Kolasy (2008), który na podstawie modelu DSGE otrzymał, że wzrost wydatków rządowych powoduje istotny spadek inwestycji ${ }^{36}$.

Porównanie otrzymanych wyników z wynikami uzyskanymi dla podażowego modelu realnego cyklu koniunkturalnego wskazuje, że uwzględnienie efektów popytowych znacznie zwiększa siłę oddziaływania wydatków rządowych na produkcję. W modelu RBC przejściowy wzrost wydatków rządowych o $1 \%$ PKB prowadził bowiem do zwiększenia PKB zaledwie o ok. $0,2 \%$, podczas gdy w modelu nowokeynesistowskim - o ok. $0,8 \%$. Uzyskane dla obydwu modeli rezultaty mogą świadczyć o tym, że efekt popytowy wzrostu wydatków jest w gospodarce polskiej silniejszy niż efekt podażowy. Wyniki wskazujące na znacznie słabsze oddziaływanie wydatków rządowych w modelu Hansena mogą mieć jednak również inne źródła, m.in. wynikać mogą z odmiennej metody szacowania parametrów lub innej postaci funkcji użyteczności. Dlatego w celu porównania siły efektów popytowych i podażowych na gruncie jednego modelu w modelu nowokeynesistowskim wyodrębniono efekty podażowe i popytowe. Podażowe oddziaływanie wydatków rządowych zdefiniowano jako ich wpływ w przypadku doskonale elastycznych cen i płac $^{37}$. Efekty popytowe zdefiniowano natomiast jako oddziaływanie polityki fiskalnej wynikające $\mathrm{z}$ występowania sztywności nominalnych, czyli wyznaczono jako różnicę miedzy otrzymanymi całkowitym efektami wzrostu wydatków rządowych a oszacowaniem efektu podażowego.

$\mathrm{Na}$ rysunku 8 ukazano oddziaływanie zwiększenia wydatków rządowych w dekompozycji na efekt podażowy i popytowy.

\footnotetext{
${ }^{35}$ Lub ekwiwalentnie - wzrostem zryczałtowanych podatków.

${ }^{36}$ Analogiczne wnioski dotyczące kierunku oddziaływania przejściowych zmian wydatków rządowych na inwestycje w modelu nowokeynesistowskim otrzymali dla gospodarki amerykańskiej m.in. Botman i Kumar (2006).

${ }^{37}$ Dla $\xi_{w}, \xi_{P}=0$.
} 
produkcja - efekt podażowy

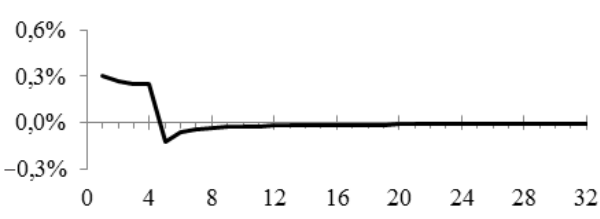

produkcja - efekt popytowy

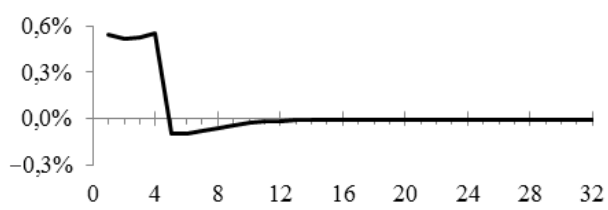

Rysunek 8. Podażowe oraz popytowe oddziaływanie jednorocznego zwiększenia wydatków rządowych o 1\% PKB na procentowe odchylenie produkcji od poziomu bazowego (dane kwartalne)

Źródło: opracowanie własne na podstawie danych Eurostatu, GUS i Ministerstwa Finansów.

Wzrost wydatków rządowych oddziałuje na produkcję przede wszystkim poprzez efekt popytowy. W przypadku braku występowania sztywności nominalnych przejściowe zwiększenie wydatków rządowych o 1\% PKB skutkowałoby średniorocznym wzrostem produkcji w pierwszym roku po wystąpieniu szoku wynoszącym $0,25 \%$. Natomiast występowanie sztywności nominalnych powoduje, że PKB ulega zwiększeniu dodatkowo o $0,55 \%$. Zarówno efekt podażowy, jak i popytowy jest przy tym przejściowy. Ponadto w obydwu przypadkach następuje efekt ,,przestrzelenia". W przypadku efektu podażowego jest on następstwem niższego poziomu kapitału, który jest potem stopniowo odbudowywany. W przypadku efektu popytowego wynika natomiast z przyzwyczajeń konsumpcyjnych. Wyższe wydatki rządowe w okresie trwania szoku wypychają konsumpcję. Tuż po zakończeniu szoku popyt maleje poniżej poziomu wyjściowego, ponieważ z jednej strony na agregatowy popyt przestają oddziaływać wyższe wydatki rządowe, a z drugiej strony gospodarstwa domowe są przyzwyczajone do niższej konsumpcji.

Podniesienie wydatków rządowych, jak wspomniano wcześniej, oddziałuje na wzrost zatrudnienia zarówno poprzez mechanizmy popytowe, jak i podażowe. Jednocześnie każdy z tych mechanizmów w odmienny sposób oddziałuje na kształtowanie się wynagrodzeń. Jeśli wzrost popytu na pracę wynikający z wyższego agregatowego popytu jest większy niż wzrost podaży pracy wynikający z negatywnego efektu majątkowego, wówczas poziom płac ulega zwiększeniu. W przeciwnym wypadku, analogicznie jak w modelu RBC, następuje spadek poziomu płac. Oddziaływanie wydatków rządowych na rynek pracy w dekompozycji na efekt podażowy i popytowy ukazano na rysunku 9.

Z funkcji reakcji na impuls wynika, że zwiększenie wydatków rządowych powoduje wzrost zatrudnienia głównie dzięki mechanizmom popytowym. Ponadto oddziaływanie efektów podażowych na stawkę płac jest słabsze niż czynników popytowych i w konsekwencji następuje wzrost stawki płac ${ }^{38}$. Uzyskane rezultaty

\footnotetext{
${ }^{38} \mathrm{Na}$ sposób reakcji wynagrodzeń na zmiany poziomu wydatków rządowych oddziałuje w pewnym stopniu występowanie przyzwyczajeń konsumpcyjnych. Przyzwyczajenia konsumpcyjne powodują bowiem, że przedsiębiorstwa częściowo ograniczają narzuty, w wyniku czego większy
} 
wskazują więc, że w gospodarce polskiej wydatki rządowe w większym stopniu wpływają na rynek pracy poprzez agregatowy popyt niż poprzez efekty podażowe.
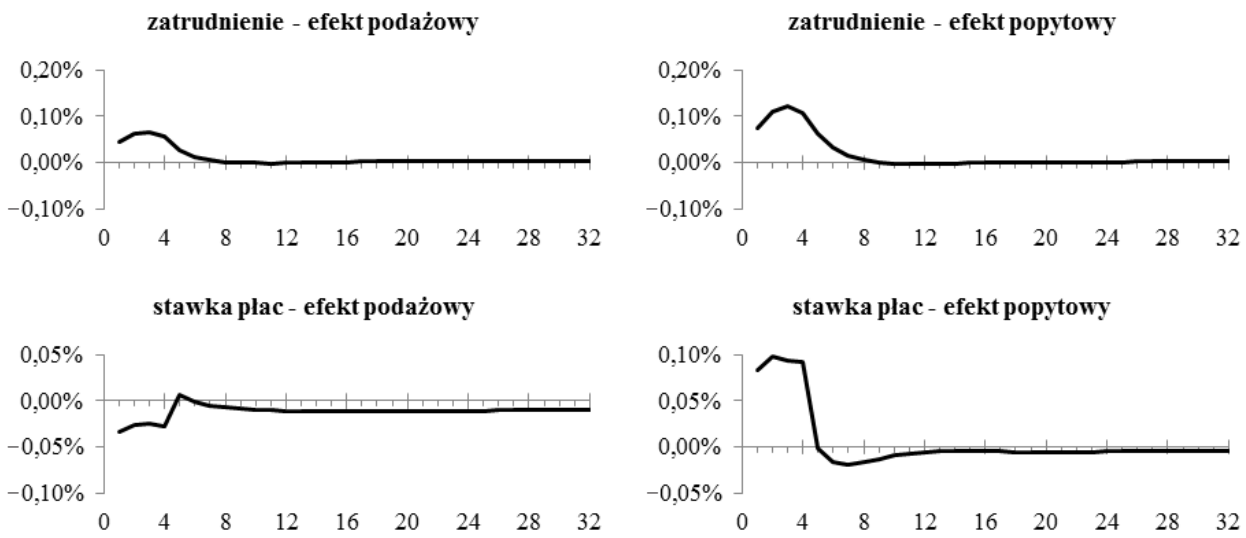

Rysunek 9. Podażowe oraz popytowe oddziaływanie trwającego jeden rok wzrostu wydatków rządowych o $1 \%$ PKB na procentowe odchylenie zatrudnienia i stawki płac od poziomu bazowego (dane kwartalne)

Źródło: opracowanie własne na podstawie danych Eurostatu, GUS i Ministerstwa Finansów.

Odmienny jest również podażowy i popytowy kierunek oddziaływania wydatków rządowych na kształtowanie się konsumpcji prywatnej. W tym przypadku z przeprowadzonych symulacji wynika, że efekt podażowy jest silniejszy. W rezultacie wyższe wydatki rządowe prowadzą do zmniejszenia się konsumpcji prywatnej (por. rys. 10).
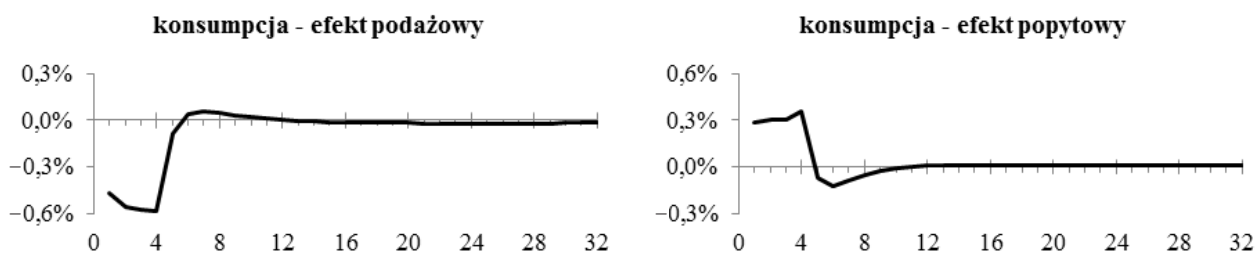

Rysunek 10. Podażowe oraz popytowe oddziaływanie trwającego jeden rok wzrostu wydatków rządowych o $1 \%$ PKB na procentowe odchylenie konsumpcji od poziomu bazowego (dane kwartalne)

Źródło: opracowanie własne na podstawie danych Eurostatu, GUS i Ministerstwa Finansów.

jest wzrost popytu na pracę, którego wpływ na kształtowanie się stawki płac jest w rezultacie silniejszy, niż w przypadku podaży pracy (por. Ravn, Schmitt-Grohe, Uribe, 2006). 
Jedną z przyczyn występowania ujemnej zależności pomiędzy konsumpcją prywatną i publiczną jest przyjęcie założenia o występowaniu w gospodarce homogenicznych gospodarstw domowych podejmujących decyzje optymalizacyjne (por. Linnemann i Schabert, 2003; Bouakez, Rebei, 2007). Podobne wyniki na podstawie modeli nowokeynesistowskich zakładających występowanie jedynie gospodarstw ricardiańskich uzyskali dla gospodarki polskiej Bukowski i in. (2005), dla amerykańskiej - Gali, Lopez-Salido i Valles (2007) oraz Cogan i in. (2009), a dla strefy euro - Smets i Wouters (2003) oraz Coenen i Straub (2005) ${ }^{39}$. Jak wskazują Gali, Lopez-Salido i Valles (2007) wysoki udział gospodarstw niericardiańskich powoduje, że zmienia się kierunek oddziaływania wydatków rządowych na poziom konsumpcji. Dlatego rozszerzenie modelu nowokeynesistowskiego dla gospodarki polskiej o założenia dotyczące występowanie gospodarstw niericardiańskich, podejmujących decyzje na podstawie jedynie bieżącego dochodu, stanowi interesujący obszar do dalszych badań.

\subsection{Oddziaływanie szoków dotyczących podatków niezryczaltowanych}

Jak wynika z przedstawionych we wcześniejszym podrozdziale symulacji przejściowe podwyższenie wydatków rządowych powoduje wzrost PKB. Kierunek oddziaływania zwiększenia stopy podatkowej jest natomiast odmienny. Na rysunku 11 przedstawiono oddziaływanie szoku w polityce fiskalnej, polegającego na trwającym jeden rok podwyższeniu stopy opodatkowania dochodów o 1 pkt proc. na kształtowanie się poszczególnych zmiennych (jeden okres oznacza kwartał).

Wzrost stopy opodatkowania obniża zarówno poziom zatrudnienia, jak i kapitału. W rezultacie produkcja ulega istotnemu obniżeniu. Z przeprowadzonych symulacji wynika, że przejściowy wzrost stopy podatkowej o 1 pkt proc. prowadzi od ograniczenia PKB o ok. 1,4\%. Podobnie jak w przypadku modelu RBC otrzymano zatem, że produkcja bardzo silnie reaguje na zmiany stóp podatkowych ${ }^{40}$. Zmiany stopy podatkowej oddziałują na kształtowanie się zarówno krańcowego dochodu z kapitału po opodatkowaniu, jak i krańcowego dochodu z pracy po opodatkowaniu.

${ }^{39}$ Coenen i Straub (2005) oraz Gali, Lopez-Salido i Valles (2007) analizują również wersje modeli z gospodarstwami niericardiańskimi.

${ }^{40}$ Jednocześnie porównanie wyników uzyskanych na podstawie obydwu modeli ukazuje, że występowanie sztywności nominalnych nie zwiększa siły oddziaływania zmian stóp podatkowych na PKB. Brak silnego wpływu popytowego wynika $z$ faktu, że analizowane zmiany stóp podatkowych są rekompensowane zmianami zryczałtowanych podatków. W rezultacie łączne wpływy podatkowe, pomniejszające dochody do dyspozycji, utrzymują się na stałym poziomie, natomiast zmniejszeniu ulegają wielkości krańcowe, wpływające na optymalizacyjne decyzje gospodarstw domowych i przedsiębiorstw. 
Z jednej strony wyższe opodatkowanie wpływa na wartość oczekiwaną stopy zwrotu z kapitału, a w rezultacie na wartość kapitału (por. równanie (262)). Obniżenie się wartości kapitału wpływa na poziom inwestycji (por. równanie (260)), co przekłada się na kształtowanie się ilości kapitału rzeczowego. Z drugiej strony wzrost stopy podatkowej obniża dochody netto z pracy. Niższa płaca netto wpływa na podaż pracy oferowaną przez gospodarstwa domowe (por. równanie (257)). Niższa podaż pracy skutkuje z kolei obniżeniem się poziomu zatrudnienia.
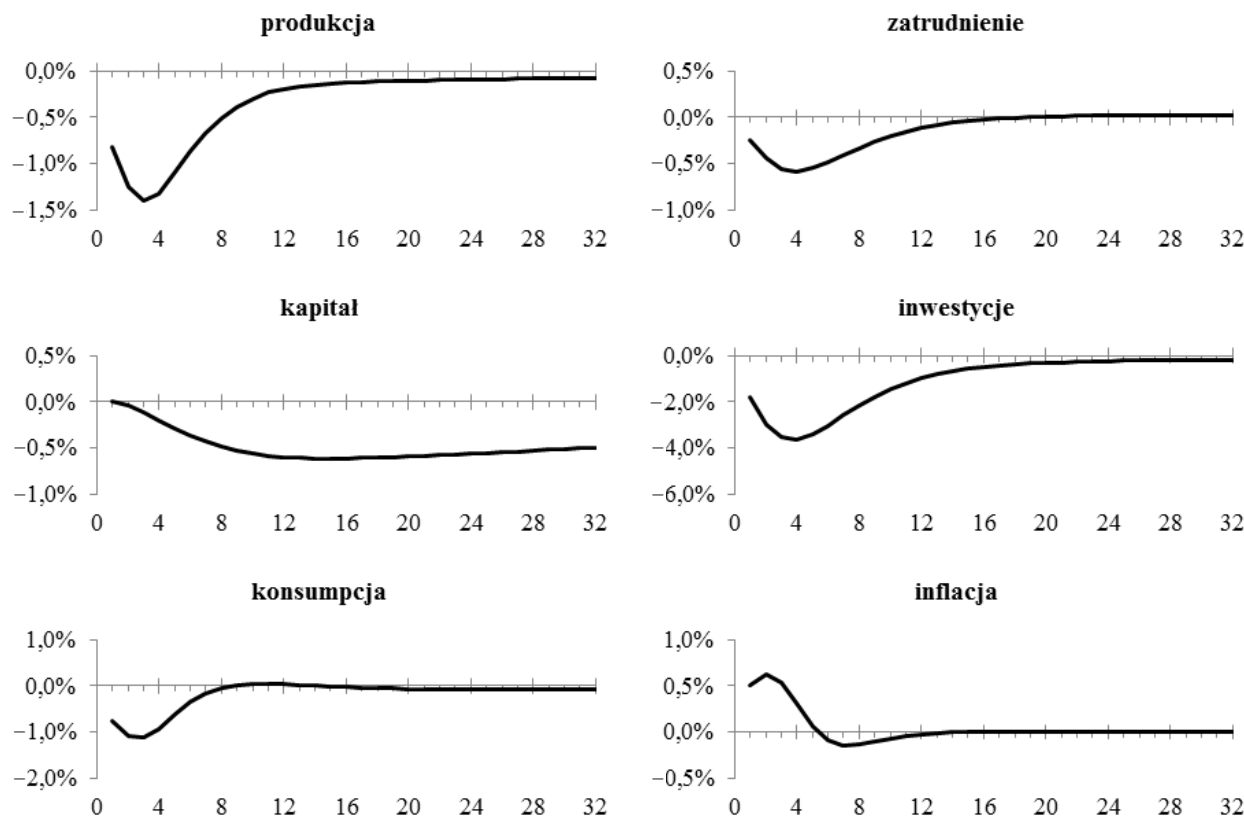

stawka plac

stopa procentowa
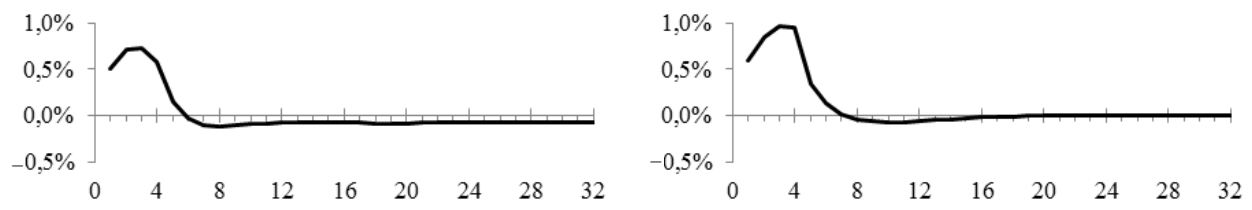

Rysunek 11. Oddziaływanie trwającego jeden rok podniesienia stopy podatkowej o 1 pkt proc. na procentowe odchylenie poszczególnych zmiennych od poziomu bazowego (dane kwartalne)

Źródło: opracowanie własne na podstawie danych Eurostatu, GUS i Ministerstwa Finansów.

W wyniku zatem zwiększenia opodatkowania maleje poziom każdego z czynników produkcji, co przekłada się na poziom PKB. Jednocześnie zmiana opodatkowania, poprzez ograniczenie podaży pracy, wpływa na podniesienie 
się stawki płac przed opodatkowaniem ${ }^{41}$. Zgodnie z nowokeynesistowską krzywą Phillipsa poziom inflacji jest powiązany z kształtowaniem się płac (por. równanie (256)). Wyższa inflacja wywołuje reakcję banku centralnego - podniesienie stopy procentowej. Wzrost oprocentowania ponad inflację oddziałuje z kolei na decyzje gospodarstw domowych, wpływając na ograniczenie konsumpcji prywatnej.

Również na podstawie modeli nowokeynesistowskich dla innych krajów otrzymuje się, że wzrost stopy podatkowej prowadzi do istotnego ograniczenia PKB (por. np. Ratto, Roeger, in't Veld, 2008; Yasuharu, 2009; van Brusselen, 2010; Zubairy, 2010; Chahrour, Schmitt-Grohe, Uribe, 2012). Przykładowo Chahrour, Schmitt-Grohe i Uribe (2012) na podstawie modelu dla gospodarki amerykańskiej oszacowali mnożnik podatkowy na poziomie $-1,78$. Wysoka co do wartości bezwzględniej wartość mnożnika podatkowego wynika z faktu, że wyższa stopa podatkowa oddziałuje negatywnie na produkcję zarówno poprzez mechanizmy popytowe, jak i podażowe. Wyniki uzyskane przez Bukowskiego $i$ in. (2005) na podstawie modelu nowokeynesistowskiego dla gospodarki polskiej prowadzą do analogicznych wniosków.

W analizowanym modelu występowała jedna stopa podatkowa, nakładana na dochody. Uwzględniając, że opodatkowanie dochodów z kapitału kształtować może się w odmienny sposób niż opodatkowanie dochodów z pracy równania (262) oraz (257) przyjmują postać:

$$
\begin{aligned}
& \widetilde{Q}_{t}=-\left(\widetilde{R}_{t}-E_{t}\left(\widetilde{\pi}_{t+1}\right)\right)+\frac{1-\delta}{1-(1-\tau) \delta+(1-\tau) \bar{r}^{k}} E_{t}\left(\widetilde{Q}_{t+1}\right)+ \\
& +\frac{\bar{r}^{k}(1-\tau)}{1-(1-\tau) \delta+(1-\tau) \bar{r}^{k}} E_{t}\left(\widetilde{r}_{t+1}^{k}-\widetilde{\tau}_{t+1}^{k}\right)+\zeta_{Q, t}, \\
& \widetilde{w}_{t}=\frac{\beta}{1+\beta} E_{t}\left(\widetilde{w}_{t+1}\right)+\frac{1}{1+\beta} \widetilde{w}_{t-1}+\frac{\beta}{1+\beta} E_{t}\left(\widetilde{\pi}_{t+1}\right)-\frac{1+\beta \gamma_{w}}{1+\beta} \widetilde{\pi}_{t}+\frac{\gamma_{w}}{1+\beta} \widetilde{\pi}_{t-1}+ \\
& -\frac{1}{1+\beta} \frac{\left(1-\beta \xi_{w}\right)\left(1-\xi_{w}\right)}{\left(1+\frac{\left(1+\lambda_{w}\right) \sigma_{l}}{\lambda_{w}}\right) \xi_{w}}\left(\widetilde{w}_{t}-\widetilde{\tau}_{t}^{w}-\sigma_{l} \widetilde{L}_{t}-\frac{\sigma_{c}}{1-a_{v}}\left(\widetilde{C}_{t}-a_{v} \widetilde{C}_{t-1}\right)-\widetilde{\varepsilon}_{t}^{l}-\eta_{w, t}\right),
\end{aligned}
$$

gdzie kształtowanie się stopy opodatkowania dochodów z kapitału oraz dochodów z pracy określają procesy autoregresyjne, analogiczne jak w przypadku równania (252).

W rezultacie, w przypadku uwzględnienia odmiennego opodatkowania dochodów z kapitału i wynagrodzeń, dynamikę modelu określają równania (253)(256), (258)-(261) oraz (263)-(268). Wyznaczone na podstawie estymacji

\footnotetext{
${ }^{41}$ Przy czym stawka płac netto (po opodatkowaniu) ulega obniżeniu.
} 
bayesowskiej oszacowania parametrów kształtują się na zbliżonym poziomie jak w przypadku modelu z jedną stopą podatkową.

Z przeprowadzonych symulacji wynika, że wzrost opodatkowania wynagrodzeń silniej oddziałuje na ograniczenie produkcji niż wzrost opodatkowania dochodów z kapitału. Przejściowa podwyżka opodatkowania wynagrodzeń o 1 pkt proc. prowadzi od obniżenia się PKB o ok. 1,4\%. Natomiast analogiczne zwiększenie opodatkowania dochodów z kapitału przekłada się na jedynie nieznaczny spadek produkcji, wynoszący ok. $0,1 \%$. Otrzymane wyniki są więc podobne jak w modelu RBC. W przypadku przejściowego podniesienia opodatkowania wynagrodzeń o 1 pkt proc. stawka płac brutto ulega zwiększeniu o ok. 0,7\%. Jednocześnie stawka płac netto maleje. Niższa płaca netto wpływa na ograniczenie podaży pracy. W wyniku wzrostu opodatkowania dochodów z pracy zmniejszeniu ulegają również inwestycje i konsumpcja prywatna. Przy wyższych płacach brutto zwiększeniu ulega inflacja.

Odmienną reakcję gospodarki otrzymuje się w sytuacji podwyższenia opodatkowania dochodów $\mathrm{z}$ kapitału. W tym przypadku co prawda również następuje spadek produkcji, ilości kapitału i zatrudnienia, ale jednocześnie wpływ na konsumpcję, stawkę płac i inflację jest inny niż w przypadku zmian opodatkowania wynagrodzen. Wartości tych zmiennych ulegają bowiem przejściowemu wzrostowi. Konsumpcja ulega zwiększeniu, gdyż wyższe podatki nakładane na dochody z kapitału powodują, że podmioty zastępują przynoszący niższe dochody netto kapitał konsumpcją. Stawka płac maleje, ponieważ przy niższej ilości kapitału maleje również popyt na pracę. Inflacja ulega obniżeniu w wyniku zmniejszenia się agregatowego popytu oraz stawki płac.

\subsection{Wpływ wydatków rządowych finansowanych podatkami zależnymi od dochodu}

Oprócz efektów podniesienia wydatków rządowych sfinansowanych wyższymi podatkami zryczałtowanymi, podobnie jak w przypadku podażowego modelu RBC, zbadany został wpływ zwiększenia wydatków rządowych, któremu towarzyszy podniesienie podatków zależnych od dochodu. W takim przypadku zmiany stóp podatkowych nakładanych na dochody są zdeterminowane przez szoki dotyczące wydatków rządowych. Stopa podatkowa dostosowuje się w taki sposób, by w wyniku szoków dotyczących wydatków rządowych nie uległo zmianie saldo budżetowe. W rezultacie zaburzenia fiskalne oddziałują na gospodarkę jednocześnie poprzez zmianę poziomu wydatków rządowych i stopy podatkowej. Na rysunku 12 ukazano reakcję gospodarki na przejściowe podniesienie wydatków rządowych o $1 \%$ PKB sfinansowane podwyżką stopy opodatkowania dochodów ${ }^{42}$.

\footnotetext{
${ }^{42}$ Wyniki symulacji dotyczą wersji modelu z jedną stopą opodatkowania dochodów $\tau_{t}$.
} 
produkcja

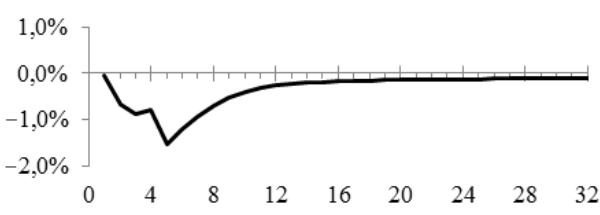

kapital

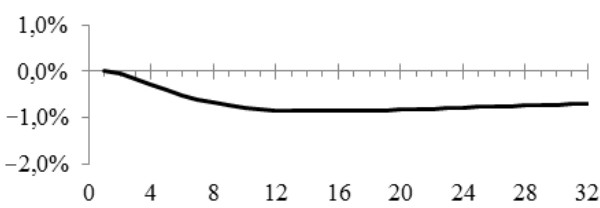

konsumpcja

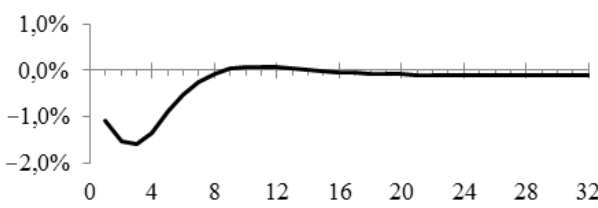

stawka plac

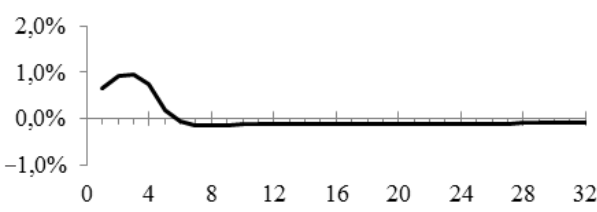

zatrudnienie

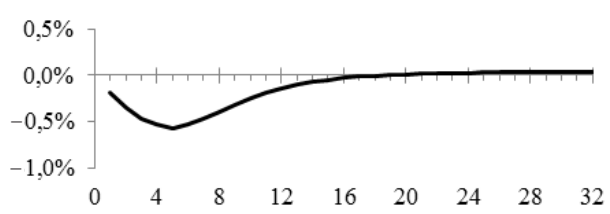

inwestycje

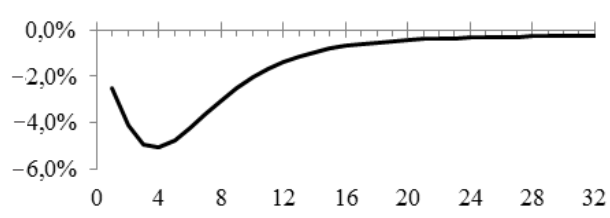

inflacja

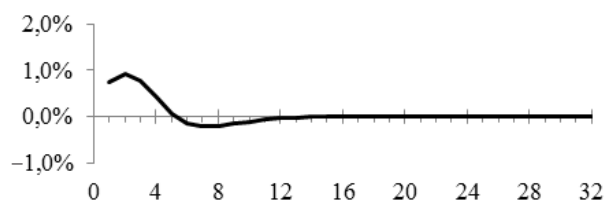

stopa procentowa

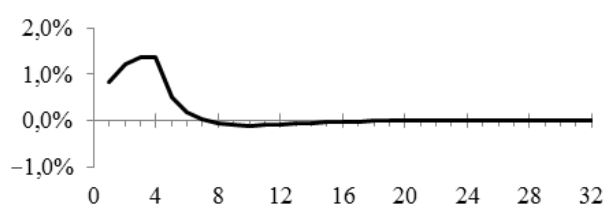

Rysunek 12. Oddziaływanie trwającego jeden rok wzrostu wydatków rządowych o 1\% PKB finansowanego wyższą stopą podatkową na procentowe odchylenie poszczególnych zmiennych od poziomu bazowego (dane kwartalne)

Źródło: opracowanie własne na podstawie danych Eurostatu, GUS i Ministerstwa Finansów.

Z wygenerowanych funkcji reakcji na impuls wynika, że wzrost wydatków rządowych finansowany wyższą stopą opodatkowania wywiera negatywny wpływ na produkcję. Negatywne oddziaływanie wyższych podatków na PKB jest więc silniejsze niż wzrost produkcji wynikający z wyższych wydatków rządowych.

Pozytywne oddziaływanie wydatków rządowych na poziom agregatowego popytu ma charakter krótkotrwały - trwa jedynie w okresie szoku. Natomiast negatywny wpływ wyższego opodatkowania na produkcję ma charakter bardziej długotrwały. W rezultacie w przypadku przejściowego podwyższenia wydatków rządowych finansowanego wyższymi podatkami nakładanymi na 
dochody PKB osiąga najniższy poziom nie tuż po wystąpieniu szoku, lecz po jego zakończeniu.

Jak wynika z przeprowadzonych symulacji, wszystkie zmienne realne, poza wydatkami rządowymi, w wyniku pojawienia się analizowanego zaburzenia fiskalnego ulegają ograniczeniu. Najmniejszym wahaniom podlega zatrudnienie, co wiąże się z tym, że kierunek wpływu wydatków rządowych i stopy podatkowej jest w przypadku tej zmiennej odmienny. Natomiast na pozostałe zmienne zwiększenie wydatków rządowych i opodatkowania oddziałuje w tym samym kierunku. Szczególnie silny negatywny wpływ szoku fiskalnego jest widoczny w przypadku inwestycji.

W wyniku wzrostu wydatków rządowych finansowanego podniesieniem podatków zależnych od dochodu zwiększeniu ulegają wszystkie zmienne nominalne - nominalna stawka płac, inflacja oraz stopa procentowa. Wahania wymienionych zmiennych są przy tym relatywnie duże. Wydatki rządowe i podatki oddziałują bowiem na ich przebieg w tym samym kierunku.

Uzyskane wyniki dotyczące kierunku oddziaływania analizowanego szoku fiskalnego na PKB oznaczają, że mimo iż w przypadku występowania sztywności nominalnych wzrost wydatków wywiera silniejszy wpływ na gospodarkę niż w modelu RBC, to jednak nadal negatywne oddziaływanie wyższych krańcowych stóp podatkowych jest silniejsze. Otrzymane dla Polski wyniki są odmienne niż wynika to z oszacowań Zubairy (2010). Autorka na podstawie modelu nowokeynesistowskiego estymowanego na danych amerykańskich uzyskała bowiem, że zwiększenie wydatków rządowych prowadzi do wzrostu produkcji, niezależnie czy wydatki są finansowane podatkami zryczałtowanymi, czy też niezryczałtowanymi ${ }^{43}$. Z kolei z symulacji, które przedstawili Botman i Kumar (2006) wynika, że w warunkach występowania sztywności nominalnych na skutek zwiększenia wydatków rządowych finansowanego podwyżką podatków niezryczałtowanych PKB po krótkotrwałym wzroście spada poniżej poziomu sprzed wystąpienia szoku fiskalnego ${ }^{44}$. Również Uhlig (2010) wskazuje, że w przypadku finasowania dodatkowych wydatków rządowych wyższą stopą opodatkowania następuje spadek produkcji. Zgodnie z symulacjami Uhliga, wykonanymi na podstawie modelu DSGE dla gospodarki amerykańskiej, wzrost wydatków rządowych o 1\% PKB całkowicie sfinansowany wyższymi podatkami niezryczałtowanymi skutkuje obniżeniem się produkcji o ok. $0,7 \%$, czyli relatywnie mniejszym niż wynika to $\mathrm{z}$ modelu dla gospodarki polskiej ${ }^{45}$.

${ }^{43}$ Jak wskazuje Eggertsson $(2010$, 2011) wydatki rządowe finansowane wyższymi podatkami dochodowymi mogą prowadzić do wzrostu PKB szczególnie wtedy, gdy gospodarka zbliża się do granicy zerowych stóp procentowych.

${ }^{44}$ Początkowy wzrost produkcji jest następstwem tego, że Botman i Kumar (2006) przyjmują, że dostosowanie stopy podatkowej następuje z pewnym opóźnieniem.

${ }^{45}$ Uhlig (2010) wskazuje ponadto, że jeśli wydatki rządowe są częściowo finansowane podwyżką stopy podatkowej, a częściowo długiem publicznym, wówczas negatywne oddziaływanie polityki fiskalnej na produkcję jest jeszcze słabsze. 


\section{Podsumowanie}

W rozdziale na podstawie modelu nowej ekonomii keynesistowskiej oszacowano siłę oddziaływania wydatków rządowych i podatków na wahania koniunktury w Polsce. Analizę przeprowadzono na podstawie modelu Smetsa i Woutersa (2003), który rozszerzono o założenia dotyczące występowania podatków niezryczałtowanych. W modelu przyjęto, że ceny i płace dostosowują się stopniowo, zgodnie ze schematem Calvo (1983), a więc poprzez założenie występowania sztywności nominalnych uwzględniono popytowe oddziaływanie polityki fiskalnej. Ponadto do głównych cech modelu zaliczyć można występowanie zaproponowanych przez Abela (1990) przyzwyczajeń konsumpcyjnych, kosztów dostosowania ilości kapitału, kosztów zmiennego stopnia wykorzystania kapitału oraz polityki pieniężnej prowadzonej zgodnie z regułą Taylora (1993).

Parametry modelu oszacowano na podstawie danych dla gospodarki polskiej przy wykorzystaniu metody bayesowskiej. Z przeprowadzonych symulacji wynika, że sfinansowane zryczałtowanymi podatkami podniesienie wydatków rządowych o $1 \%$ PKB prowadzi do przejściowego wzrostu produkcji o ok. $0,8 \%$. Porównując wyniki otrzymane dla gospodarki polskiej, z uzyskanymi na podstawie modeli nowokeynesistowskich dla gospodarki amerykańskiej i strefy euro oszacowaniami Coenena i Strauba (2005), Ratto, Roegera i in't Velda (2008) czy Wielanda i in. (2012), zaobserwować można, że przy występowaniu sztywności nominalnych oddziaływanie wydatków rządowych w gospodarce polskiej jest relatywnie silne. Natomiast badanie Caraianiego (2010) dotyczące krajów Europy Środkowej ukazuje, że siła oddziaływania polityki fiskalnej na kształtowanie się PKB jest w Polsce podobna jak w Czechach, słabsza niż w Rumunii, a silniejsza niż na Węgrzech.

W modelu zwiększenie wydatków rządowych wpływa na wzrost produkcji zarówno poprzez czynniki podażowe, związane z negatywnym efektem majątkowym, jak i popytowe, wynikające z oddziaływania agregatowego popytu na poziom produkcji w warunkach sztywności nominalnych. Wyodrębnienie na gruncie modelu Smetsa i Woutersa efektów podażowych i popytowych wskazuje przy tym, że wzrost wydatków rządowych oddziałuje na produkcję przede wszystkim poprzez efekt popytowy. Otrzymano, że w wyniku przejściowego zwiększania wydatków rządowych o $1 \%$ PKB w przypadku braku występowania sztywności nominalnych wzrost produkcji wyniósłby jedynie $0,25 \%$. Natomiast występowanie dostosowań cenowych typu Calvo sprawia, że produkcja ulega zwiększeniu dodatkowo o $0,55 \%$.

Dekompozycja oddziaływania wydatków rządowych na komponent popytowy i podażowy jest szczególnie interesująca $\mathrm{w}$ przypadku stawki płac oraz konsumpcji prywatnej, ponieważ czynniki podażowe i popytowe wpływają na te zmienne w przeciwnych kierunkach. Przeprowadzone symulacje wskazują, że 
wydatki rządowe oddziałują na rynek pracy głównie poprzez agregatowy popyt. W rezultacie podniesienie wydatków rządowych powoduje wzrost stawki płac. W przypadku konsumpcji otrzymano z kolei, że efekt podażowy jest silniejszy niż efekt popytowy. Zatem, podobnie jak m.in. u Bukowskiego i in. (2005) oraz Cogana i in. (2009) uzyskano, że wzrost wydatków rządowych poprzez efekt wypychania prowadzi do spadku konsumpcji prywatnej. Jak wskazują Gali, Lopez-Salido i Valles (2007) przeciwny kierunek oddziaływania polityki fiskalnej na konsumpcję prywatną ma natomiast miejsce wówczas, gdy występuje duży odsetek gospodarstw niericardiańskich.

Na podstawie modelu uzyskano, że wzrost stopy opodatkowania obniża zarówno poziom zatrudnienia, jak i kapitału. W rezultacie w wyniku zwiększenia stopy opodatkowania o 1 pkt proc. produkcja ulega obniżeniu o ponad $1 \%$. Produkcja bardzo silnie reaguje zatem na zmiany stóp podatkowych. Podobne wyniki otrzymali Chahrour, Schmitt-Grohe i Uribe (2012) na podstawie modelu nowokeynesistowskiego dla gospodarki amerykańskiej.

Jak wynika z przeprowadzonych symulacji wzrost opodatkowania wynagrodzeń silniej oddziałuje na ograniczenie produkcji niż wzrost opodatkowania dochodów z kapitału. Przejściowa podwyżka opodatkowania wynagrodzeń o 1 pkt proc. prowadzi od obniżenia się PKB o ok. 1,4\%. Natomiast analogiczne zwiększenie opodatkowania dochodów z kapitału przekłada się na jedynie nieznaczny spadek produkcji, wynoszący ok. $0,1 \%$. Wyniki dotyczące skutków zmian stóp podatkowych są więc podobne jak w modelu RBC.

Przeprowadzone symulacje umożliwiają porównanie efektywności, jako narzędzia stymulowania koniunktury, dwóch wariantów polityki fiskalnej: zwiększenia wydatków rządowych oraz obniżenia stopy opodatkowania dochodów. Z modelu wynika, że obniżenie stopy podatkowej bardziej zwiększa produkcję niż podnoszenie o analogiczną wielkość wydatków rządowych. Obniżenie stopy opodatkowania silnej niż wydatki rządowe oddziałuje na obydwa czynniki produkcji - zarówno kapitał, jak i zatrudnienie. Niższe opodatkowanie prowadzi ponadto do wzrostu konsumpcji i inwestycji oraz spadku inflacji, podczas gdy wydatki rządowe, poprzez efekt wypychania, ograniczają inwestycje i konsumpcję oraz wpływają na wzrost inflacji. Zatem obniżenie stopy podatkowej stanowi efektywniejszą metodę stymulowania gospodarki niż ponoszenie wydatków rządowych. Otrzymane wyniki, oparte na modelu uwzględniającym zarówno mechanizmy podażowe, jak i popytowe, są więc odmienne niż wynikałoby to z czysto popytowego podejścia nie bazującego na podstawach mikroekonomicznych, zgodnie z którym wydatki rządowe najsilniej oddziałują na agregatowy popyt. Warto jednocześnie zaznaczyć, że, jak wskazuje m.in. Orłowski (2008), obniżanie stóp podatkowych wpływa w odmienny sposób na redystrybucję dochodów niż podnoszenie wydatków rządowych. Zwiększanie wydatków zmniejsza bowiem nierówności dochodowe, natomiast obniżanie podatków prowadzi do ich zwiększenia (por. Owsiak, 2012). Biorąc zatem pod uwagę jedynie antycykliczną funkcję polityki fiskalnej w 
okresie spowolnienia gospodarczego bardziej wskazane jest obniżanie stóp podatkowych. Natomiast, uwzględniając również jej funkcję redystrybucyjną, wnioski dotyczące optymalnej reakcji władz fiskalnych na zmiany koniunktury nie są już takie jednoznaczne. Warto również dodać, że w przypadku załamania się sytuacji gospodarczej znacznej zmianie mogą ulec mnożniki fiskalne (por. Blanchard, Leigh, 2013), co może rzutować na optymalny kształt antycyklicznej polityki fiskalnej w przypadku zaistnienia recesji gospodarczej w Polsce.

Zbadano również konsekwencje podwyżki wydatków rządowych sfinansowanej podniesieniem stopy podatkowej. Zaobserwowano, że taka polityka fiskalna prowadzi do obniżenia produkcji. Kierunek oddziaływania wydatków rządowych finansowanych podatkami niezryczałtowanymi jest więc taki sam jak u Uhliga (2010), a odmienny niż wynika to z nowokeynesistowskiego modelu Zubairy (2010).

Przeprowadzone symulacje wskazują, że w gospodarce polskiej zwiększenie się PKB na skutek podniesienia wydatków rządowych jest bardzo krótkotrwałe, natomiast negatywny wpływ wyższego opodatkowania na produkcję ma charakter bardziej długotrwały i jedynie stopniowo wygasa po okresie wystąpienia szoku. W rezultacie w przypadku podwyższenia wydatków rządowych sfinansowanego wyższymi niezryczałtowanymi podatkami PKB osiąga najniższy poziom nie tuż po wystąpieniu szoku, lecz po jego zakończeniu. Ponadto, w wyniku równoczesnego podniesienia wydatków rządowych i stopy podatkowej następuje silny efekt wypychania inwestycji. Jednocześnie w wyniku wzrostu wydatków rządowych finansowanego podniesieniem podatków zależnych od dochodu zwiększeniu ulegają wszystkie zmienne nominalne - nominalna stawka płac, inflacja oraz stopa procentowa. Wahania wymienionych zmiennych są przy tym relatywnie duże, co wynika $\mathrm{z}$ faktu, że wydatki rządowe i podatki oddziałują na ich przebieg w tym samym kierunku. 


\section{Wpływ aktywnej i pasywnej polityki fiskalnej na przebieg cyklu koniunkturalnego w gospodarce polskiej}

\section{Wprowadzenie}

Politykę fiskalną podzielić można na polityką aktywną, związaną z działaniami państwa, oraz pasywną, wynikającą z występowania automatycznych stabilizatorów koniunktury (por. np. Owsiak, 2002; Moździerz, 2009). Mają one odmienny charakter oraz przyczyny występowania, m.in. w odróżnieniu od polityki aktywnej, uruchomienie automatycznych stabilizatorów koniunktury nie wymaga decyzji władz fiskalnych. W rezultacie wyodrębnienie skutków działania automatycznych stabilizatorów koniunktury umożliwia bardziej precyzyjną ocenę prowadzonej polityki gospodarczej. $Z$ tego względu w niniejszym rozdziale zbadano oddziaływanie aktywnej i pasywnej polityki fiskalnej na przebieg cyklu koniunkturalnego w Polsce.

Działanie automatycznych stabilizatorów koniunktury wynika z występowania sprzężeń zwrotnych pomiędzy stanem finansów publicznych a fluktuacjami gospodarczymi. Badania dotyczące automatycznych stabilizatorów koniunktury sięgają lat 30. XX w. (por. Myrdal, 1939 oraz Hansen, 1941)1. W latach 80. i 90. nasiliło się zainteresowanie analizami dotyczącymi wynikającego z fluktuacji gospodarczych deficytu cyklicznego (por. np. Roger, in't Veld, 1997; Momigliano, 1999). Oprócz badań dotyczących wbudowanej reakcji salda budżetowego na sytuację gospodarczą rosnącego znaczenia nabierają również analizy cykliczności aktywnej polityki fiskalnej (por. np. Woo, 2005; Alesina i Tabellini, 2008). Wpływ współzależności pomiędzy sytuacją finansów publicznych a stanem koniunktury uwidocznił się szczególnie silnie podczas kryzysu finansowego, który rozpoczął się w 2007 roku. Próby łagodzenia skutków kryzysu poprzez prowadzenie aktywnej polityki fiskalnej, łącznie z pojawieniem się deficytów cyklicznych, doprowadziły bowiem z jednej strony do ograniczenia fluktuacji gospodarczych, a z drugiej strony do znacznego zwiększenia nierównowagi finansów publicznych w większości krajów Unii Europejskiej (por. European Commission, 2011).

Układ rozdziału jest następujący. W pierwszej kolejności przedstawiono ogólną charakterystykę aktywnej i pasywnej polityki fiskalnej. Następnie ukazano

\footnotetext{
${ }^{1}$ Powstanie i rozwijanie się koncepcji automatycznych stabilizatorów koniunktury w latach 40. XX w. zostało szczegółowo opisane w pracy Kropiwnickiego (1976).
} 
metody wyodrębniania strukturalnych i cyklicznych komponentów budżetowych, związanych z wymienionymi rodzajami polityki fiskalnej oraz oszacowano komponenty cykliczne dochodów i wydatków publicznych w Polsce w latach 1995-2010. $\mathrm{Na}$ podstawie kształtowania się, skorygowanych o wahania cykliczne podatków, wydatków rządowych oraz mnożników fiskalnych, wyznaczonych w rozdziale trzecim i czwartym, poddano analizie oddziaływanie aktywnej polityki fiskalnej na przebieg luki produktowej w Polsce. W dalszej kolejności, na podstawie kształtowania się komponentów cyklicznych dochodów i wydatków publicznych, oszacowano efektywność automatycznych stabilizatorów w gospodarce polskiej. Rozdział kończy się podsumowaniem zawierającym wnioski z przeprowadzonej analizy.

\subsection{Ogólna charakterystyka aktywnej i pasywnej polityki fiskalnej}

Zmiany deficytu budżetowego w ramach pasywnej polityki fiskalnej są następstwem właściwej niektórym rodzajom podatków i wydatków publicznych wrażliwości na zmiany PKB. W okresie recesji, wraz ze spadkiem produkcji, zatrudnienia oraz dochodów ludności i firm, maleją również dochody budżetowe (por. np. Owsiak, 2011a)². Natomiast podczas recesji wysokość wydatków publicznych związanych z bezrobociem ulega zwiększeniu. W wyniku tego, przy niezmienionej polityce fiskalnej, deficyt budżetowy rośnie podczas recesji i maleje w okresie ożywienia. Pasywna polityka fiskalna jest więc związana z występowaniem cyklicznego deficytu sektora finansów publicznych, będącego rezultatem cyklu koniunkturalnego (por. Owsiak, 2002)3. Wynikające z fluktuacji gospodarczych cykliczne komponenty dochodów i wydatków publicznych działają z kolei jako automatyczne stabilizatory koniunktury, zmniejszając skalę wahań PKB.

Aktywna polityka fiskalna jest natomiast związana ze zmianami dochodów i wydatków publicznych, nie wynikającymi z wahań koniunktury. Aktywną politykę fiskalną określa strukturalny deficyt sektora finansów publicznych. Deficyt strukturalny jest wielkością hipotetyczną, informującą o tym, jaka byłaby wysokość deficytu, gdyby rzeczywista produkcja równała się produkcji potencjalnej, czyli nie występowała luka produktowa (por. Józefiak, Krajewski, Mackiewicz, 2006)4.

\footnotetext{
${ }^{2}$ Warto przy tym zaznaczyć, że wahania koniunktury oddziałują zarówno na dochody sektora rządowego, jak i samorządowego (por. np. Guziejewska 2010a, 2010b).

${ }^{3}$ Jak wskazują Pietrzak, Polański i Woźniak (2003), s. 692 - „deficyt cykliczny (koniunkturalny) jest rezultatem cyklicznego przebiegu procesów gospodarczych, obrazuje wpływ cyklu koniunkturalnego na zmiany w dochodach i wydatkach budżetu i jest niezależny od bieżącej polityki fiskalnej".

${ }^{4}$ „Element strukturalny deficytu informuje, jaka jest relacja między dochodami i wydatkami budżetu przy przeciętnym (normalnym) poziomie aktywności gospodarczej” (Lubiński, 2002, s. 18).
} 
Deficyt strukturalny uzyskuje się więc poprzez skorygowanie rzeczywistego deficytu o wpływ czynników cyklicznych ${ }^{5}$. Posługiwanie się wysokością nieskorygowanego o wahania cykliczne deficytu budżetowego może mylnie wskazywać na zaostrzenie polityki fiskalnej podczas ożywienia i poluzowanie podczas recesji (por. Owsiak, Kosek-Wojnar, Surówka, 1993). Wyodrębnienie komponentu strukturalnego i cyklicznego w deficycie budżetowym umożliwia identyfikację źródeł powstawania deficytu budżetowego, określenie, czy wynika on ze zmian koniunktury gospodarczej, czy z rozwiązań systemowych, w tym działań dyskrecjonalnych państwa (Murchison, Robbins, 2002) ${ }^{6}$. Deficyt skorygowany o wahania cykliczne jest ponadto używany jako bardziej precyzyjna niż całkowity deficyt, miara restrykcyjności prowadzonej polityki fiskalnej (por. Chalk, 2002; Pietrzak, Polański, Woźniak, 2003) ${ }^{7}$.

Deficyt skorygowany o wahania cykliczne stanowi istotną miarę oceny polityki fiskalnej w Unii Gospodarczej i Walutowej. W pierwszych latach funkcjonowania Paktu Stabilności i Wzrostu wymóg zrównoważenia strukturalnego salda sektora finansów publicznych był zawarty jedynie implicite. Tworząc Pakt Stabilności i Wzrostu przyjęto, że państwa Unii powinny przyjąć średniookresowy cel utrzymywania zrównoważonego salda sektora finansów publicznych lub nadwyżki budżetowej. Zarówno na poziomie poszczególnych rządów, jak i na poziomie Komisji Europejskiej standardową praktyką była ocena spełnienia zawartego w Pakcie Stabilności i Wzrostu zapisu dotyczącego średniookresowego celu utrzymywania zrównoważonego salda na podstawie deficytu strukturalnego (Momigliano, Staderini, 1999). Interpretowano, że oceny dotyczące spełniania celów średniookresowych przez kraje członkowskie muszą uwzględniać pozycję danego kraju

${ }^{5}$ Oprócz określenia „deficyt strukturalny” stosuje się również określenie „deficyt przy pełnym zatrudnieniu” oraz „deficyt skorygowany o wahania cykliczne” (por. Musgrave, Musgrave, 1989; European Commission, 2000).

${ }^{6}$ Jednak, jak wskazuje Wojtyna (2003), deficyt strukturalny nie jest idealnym miernikiem działań władz fiskalnych, ponieważ na deficyt budżetowy mogą mieć wpływ niecykliczne zmiany o charakterze autonomicznym, np. zwiększenie zróżnicowania dochodów prowadzące do wzrostu dochodów ze względu na progresywny system podatkowy, a na bieżącą sytuację nakładają się skutki decyzji podjętych w poprzednich latach. Również Bailey (1995) oraz Chalk (2002) ukazują, że wysokość deficytu strukturalnego uzależniona jest w pewnym stopniu od szoków strukturalnych niezależnych od polityki fiskalnej, np. ze zmian cen ropy naftowej, inflacji, czy kursu walutowego.

${ }^{7}$ Warto zaznaczyć, że zmiany w poziomie deficytu strukturalnego nie zawsze jednak informują precyzyjnie o wpływie polityki fiskalnej na gospodarkę. Przykładowo, oddziaływanie zmiany deficytu strukturalnego na łączny popyt zależy od tego, czy nastąpi ona na skutek zmian w dochodach, czy w wydatkach publicznych (por. Wojtyna, 2003). Z tego względu Murchison i Robbins (2002) wyróżniają dwa wskaźniki: deficyt skorygowany o wahania cykliczne oraz poziom restrykcyjności polityki fiskalnej. Według tych autorów deficyt skorygowany o wahania cykliczne informuje o wysokości deficytu budżetowego niezależnego od wahań koniunktury i wynikającego z rozwiązań systemowych, natomiast poziom restrykcyjności polityki fiskalnej informuje o wpływie polityki fiskalnej na gospodarkę. Szerzej na temat znaczenia deficytu skorygowanego o wahania cykliczne por. Krajewski (2004). 
w ramach cyklu i wynikający z tego efekt dla salda budżetowego, a średni okres interpretowany powinien być jako czas trwania cyklu koniunkturalnego (por. Franco, 1999). W 2002 roku Komisja Europejska explicite przyjęła, że ocena polityki fiskalnej powinna opierać się na wielkości strukturalnego salda sektora finansów publicznych (por. European Commission, 2002). Zgodnie z wytycznymi Komisji Europejskiej średniookresowy cel budżetowy powinien dotyczyć salda skorygowanego o wahania cykliczne (por. European Commission, 2003, 2011), a polityka fiskalna powinna umożliwiać działanie automatycznych stabilizatorów koniunktury (por. Morris, Ongena, Schuknecht, 2006; European Commission, 2010) ${ }^{8}$. Również podpisany w 2012 roku pakt fiskalny, regulujący politykę fiskalną w strefie euro, opiera się na koncepcji deficytu skorygowanego o wahania cykliczne? ${ }^{9}$.

Do koncepcji deficytu strukturalnego częściowo nawiązuje też tzw. „sześciopak", czyli przyjęty w 2011 roku pakiet dyrektyw i rozporządzeń, które mają wzmocnić nadzór nad finansami publicznymi państw Unii Europejskiej. Zgodnie z jedną z regulacji zawartych w „sześciopaku” wydatki publiczne państw Unii nie powinny zwiększać się szybciej niż PKB w średniej perspektywie ${ }^{10}$. W rezultacie strukturalny poziom wydatków publicznych nie powinien się zwiększać ${ }^{11}$, natomiast dopuszcza się występowanie fluktuacji kategorii budżetowych, wynikających z działania automatycznych stabilizatorów ${ }^{12}$.

Dyskusja, czy istnieje uzasadnienie dla aktywnego reagowania narzędziami polityki fiskalnej na przejściowe fluktuacje gospodarcze, ma odbicie w bogatym dorobku teoretycznym na ten temat w literaturze światowej. W kolejnych okresach rozwoju makroekonomii dominowały w tej kwestii różne poglądy. Wielki Kryzys w latach 30. XX w. i teoria J. M. Keynesa utorowały drogę koncepcji korygowania niedoskonałości rynku drogą interwencji państwa. Przekonanie o słuszności aktywnej polityki regulacji agregatowego popytu przez politykę fiskalną uległo wyraźnemu osłabieniu w latach 70. , zarówno pod wpływem doświadczenia stagflacji, jak i ważnych teorii zaliczanych do nurtu nowej szkoły klasycznej (por. Barro, 1974; Sargent i Wallace, 1976; Kydland, Prescott, 1977). Od lat 90. zauważyć można znaczący renesans zainteresowania możliwymi reakcjami aktywnej polityki fiskalnej na fluktuacje gospodarcze (por. np. Linnemann, Schabert, 2003).

${ }^{8}$ Szerzej na temat Paktu Stabilności i Wzrostu por. np. Lubiński (2011) oraz Moździerz (2011).

${ }^{9}$ Zgodnie z zapisami zawartymi w pakcie fiskalnym, deficyt strukturalny w krajach strefy euro nie powinien przekraczać $0,5 \%$ PKB, a w uzasadnionych przypadkach - $1 \%$ PKB.

${ }^{10}$ Poza zasiłkami dla bezrobotnych oraz wydatkami mającymi pokrycie w dodatkowych dochodach, bezpośrednio wynikających ze zmian w przepisach podatkowych (por. European Commission, 2011).

${ }^{11}$ Lub być finansowany strukturalnymi zmianami dochodów publicznych.

${ }^{12}$ Do plusów wprowadzonego rozwiązania, w porównaniu z oceną polityki fiskalnej na podstawie poziomu deficytu strukturalnego zaliczyć można to, że opiera się ono na zmiennej obserwowalnej, która jest bardziej przejrzysta i czytelna dla opinii publicznej niż deficyt skorygowany o wahania cykliczne (por. European Commission, 2011). 
Nadal jednak z reguły przyjmuje się, że automatyczne stabilizatory koniunktury stanowią szybsze i bardziej przewidywalne narzędzie stabilizowania koniunktury niż aktywna polityka fiskalna (por. Wojtyna, 2003). Aktywna polityka fiskalna może być nieskutecznym narzędziem ograniczania wahań koniunktury ze względu na znaczne opóźnienie pomiędzy okresem, w którym powinno się zastosować bodziec fiskalny, a okresem, w którym w rzeczywistości zaczyna on oddziaływać na gospodarkę. Według Stiglitza (1988), ze względu na długie i nieprzewidywalne opóźnienia pomiędzy wystąpieniem recesji a pojawieniem się skutków zmiany polityki fiskalnej, próby stabilizacji koniunktury poprzez dyskrecjonalne zmiany w polityce fiskalnej doprowadzić mogą do wzmocnienia wahań agregatowego popytu. Mimo że problem opóźnień w polityce gospodarczej analizowany był początkowo z punktu widzenia polityki pieniężnej, to problem opóźnień jest nawet poważniejszy w przypadku polityki fiskalnej, m.in. ze względu na fakt, że aktywna polityka fiskalna charakteryzuje się długim procesem decyzyjnym (por. Belka, 2003).

Występowanie automatycznych stabilizatorów koniunktury sprzyja wygładzeniu konsumpcji i PKB (por. m.in. Musgrave, Musgrave, 1989; Buiter, 1990). Poprzez wpływ na kształtowanie się produkcji automatyczne stabilizatory oddziałują też na zmniejszenie wahań bezrobocia (por. Wojtyna, 2003). Działanie automatycznych stabilizatorów koniunktury, oprócz wpływu na zmniejszenie krótkookresowych wahań produkcji i zatrudnienia, zapobiega też częstym zmianom w systemie podatkowym i prowadzić może do podwyższenia długookresowej ścieżki PKB (por. van den Noord, 2000). Oparcie polityki fiskalnej jedynie na automatycznych stabilizatorach powoduje, że:

- polityka fiskalna wpływa na ograniczenie wahań PKB (saldo budżetowe jest procykliczne),

- nie występują opóźnienia informacyjne i decyzyjne,

- stopy podatkowe nie ulegają wahaniom w ramach cyklu.

Do minusów automatycznych stabilizatorów koniunktury można zaliczyć to, że w przypadku trwałego szoku podażowego działanie automatycznych stabilizatorów opóźnia dostosowanie PKB do nowego poziomu potencjalnego (por. Brunila, Buti, in’t Vel, 2002). Prowadzenie jedynie pasywnej polityki fiskalnej przy występowaniu deficytu strukturalnego prowadzi do narastania długu publicznego. Ponadto w przypadku znacznego ograniczenia PKB działanie automatycznych stabilizatorów koniunktury może prowadzić do bardzo wysokiego poziomu deficytu finansów publicznych, który z kolei może negatywnie wpływać na postrzeganie stabilności finansowej danego kraju i w rezultacie prowadzić do znacznego wzrostu stóp procentowych. Wpływ działania automatycznych stabilizatorów na poziom nierównowagi finansów publicznych był szczególnie widoczny po pojawieniu się kryzysu finansowego w 2007 roku. Wzrost średniego poziomu deficytu finansów publicznych w krajach Unii Europejskiej o 6,1 punktu proc. pomiędzy 2007 a 2009 rokiem wynikał bowiem aż w 50\% z działania automatycznych stabilizatorów koniunktury (European Commission, 2011). 
Istnienie sprzężenia zwrotnego między deficytem cyklicznym a wysokością wahań PKB sprawia, że działanie automatycznych stabilizatorów koniunktury zmniejsza siłę oddziaływania aktywnej polityki fiskalnej na gospodarkę. W celu zwiększenia PKB o określoną wielkość wzrost wydatków rządowych musi być wyższy przy występowaniu automatycznych stabilizatorów koniunktury niż w sytuacji braku ich występowania. Musgrave i Musgrave (1989) prezentują tę zależność za pomocą najprostszej postaci popytowego mnożnika wydatków rządowych:

$$
\Delta Y=\frac{1}{1-c} \Delta G^{\prime}=\frac{1}{1-c(1-\tau)} \Delta G^{\prime \prime},
$$

gdzie:

$G^{\prime}, G^{\prime \prime}$ - odpowiednio wydatki rządowe w sytuacji nie występowania oraz występowania automatycznych stabilizatorów,

$c$ - krańcowa skłonność do konsumpcji.

A zatem otrzymuje się:

$\Delta G^{\prime \prime}=\frac{1-c(1-\tau)}{1-c} \Delta G^{\prime}$

czyli $\Delta G^{\prime \prime}>\Delta G^{\prime}$. W celu zwiększenia PKB o określoną wielkość wzrost wydatków rządowych musi być więc wyższy przy występowaniu automatycznych stabilizatorów koniunktury, niż wówczas, gdy nie występują.

\subsection{Metody wyodrębniania deficytu strukturalnego i cyklicznego}

W pracy deficyt strukturalny i cykliczny wyznaczono korzystając z metody typu „luka produktowa + elastyczność”, opartej na szacunkach luki produktowej oraz elastyczności dochodów i wydatków budżetowych względem PKB (por. Fedelino, Ivanova, Horton, 2009) ${ }^{13}$. Wyznaczony na jej podstawie deficyt cykliczny uzależniony jest od kształtowania się luki produktowej, co z jednej strony umożliwia analizę sprzężeń zwrotnych między deficytem cyklicznym a kształtowaniem się PKB, a z drugiej strony, w odróżnieniu od podejścia zaproponowanego przez Blancharda (1990), uwzględnia, że wahania koniunktury

${ }^{13}$ Do innych, rzadziej stosowanych metod dekompozycji deficytu, zaliczyć można metody oparte na wyznaczaniu trendów podstawowych kategorii dochodów i wydatków budżetowych (por. Brandner, Diebalek i Schuberth, 1998), wyodrębnianiu cyklicznych komponentów poszczególnych zmiennych makroekonomicznych (por. Langenus, 1999 oraz Momigliano, Staderini, 1999), zastąpieniu produkcji potencjalnej obserwowalnym wskaźnikiem makroekonomicznym (por. Blanchard, 1990; Assarsson, Gidehag, Zettegren, 1999; Brunila, Tujula, 1999; Hansen, 1999) lub analizie poszczególnych działań dyskrecjonalnych państwa (Devries i in., 2011). 
mogą wynikać z innych przyczyn niż fluktuacje stopy bezrobocia. Ponadto zastosowanie metody opartej na szacunkach luki produktowej oraz elastyczności dochodów i wydatków budżetowych względem PKB zapewnia, że deficyt cykliczny nie zawiera przejściowych efektów polityki fiskalnej, niezwiązanych z wahaniami koniunktury. Jednocześnie metoda oparta na szacunkach luki produktowej i elastyczności posiada pewne ograniczenia, m.in. otrzymane wyniki uzależnione są w znaczny sposób od oszacowań luki produktowej, której wielkość jest trudna do precyzyjnego wyznaczenia, szczególnie w końcowym okresie próby. Ponadto nie uwzględnia ona tych skutków występowania cykli na rynku nieruchomości i rynkach finansowych, które oddziałują na kształtowanie się dochodów i wydatków publicznych poprzez inne kanały niż fluktuacje PKB (por. European Commission, 2011).

Zakładając, zgodnie z metodą ,luka produktowa + elastyczność”, że kształtowanie się strukturalnych dochodów i wydatków budżetowych względem rzeczywistych dochodów i wydatków zależy od kształtowania się produkcji potencjalnej względem produkcji rzeczywistej oraz od krótkookresowych elastyczności dochodów i wydatków budżetowych względem PKB otrzymuje się (por. Brandner, Diebalek, Schuberth, 1998; Fedelino, Ivanova, Horton, 2009):

$$
\begin{aligned}
& \frac{R_{i, t}^{S}}{R_{i, t}}=\left(\frac{Y_{t}^{P}}{Y_{t}}\right)^{\varepsilon_{i}}, \\
& \frac{E_{j, t}^{S}}{E_{j, t}}=\left(\frac{Y_{t}^{P}}{Y_{t}}\right)^{\beta_{j}},
\end{aligned}
$$

gdzie:

$R_{i, t}$ - dochody publiczne kategorii $i$,

$R_{i, t}^{S}-$ strukturalne dochody publiczne kategorii $i$,

$E_{j, t}$ - wydatki publiczne kategorii $j$,

$E_{j, t}^{S}-$ strukturalne wydatki publiczne kategorii $j$,

$Y_{t}^{P}$ - produkcja potencjalna (PKB skorygowane o wahania cykliczne) ${ }^{14}$,

${ }^{14}$ Deficyt skorygowany o wahania cykliczne mierzy wysokość deficytu w normalnej, typowej sytuacji gospodarczej, dlatego produkcja potencjalna w tym przypadku odnosi się do średnich wartości PKB w cyklu, w odróżnieniu od potencjalnego PKB rozumianego jako produkcja określona przez możliwości produkcyjne gospodarki, czyli produkcja w sytuacji, w której wszystkie czynniki produkcji są maksymalnie wykorzystane (por. Roger, Ongena, 1999). U. Kosterna podkreśla, że „dla uniknięcia narastania deficytów (co znajduje wyraz we wzroście wielkości długu publicznego) konieczne jest sformułowanie budżetu strukturalnego na podstawie potencjalnego PKB określonego nie szczytem produkcji lecz przeciętną środka cyklu" (Kosterna, 1995, s. 23). Dlatego w pracy produkcja potencjalna definiowana jest nie jako maksymalna możliwa produkcja, lecz jako produkcja typowa, normalna, wynikająca ze średniookresowych trendów. 
$\varepsilon_{i}-$ krótkookresowa elastyczność dochodów publicznych kategorii $i$ względem PKB,

$\beta_{j}$ - krótkookresowa elastyczność wydatków publicznych kategorii $j$ względem PKB.

Zatem strukturalne dochody i wydatki publiczne dane są następującymi wzorami:

$$
\begin{aligned}
& R_{i, t}^{S}=R_{i, t}\left(\frac{Y_{t}^{P}}{Y_{t}}\right)^{\varepsilon_{i}}, \\
& E_{j, t}^{S}=E_{j, t}\left(\frac{Y_{t}^{P}}{Y_{t}}\right)^{\beta_{j}} .
\end{aligned}
$$

Na podstawie równań (273) oraz (274) uzyskuje się, że strukturalny komponent salda budżetowego $\left(B B_{t}^{S}\right)$ określony jest wzorem postaci:

$$
B B_{t}^{S}=\sum_{i=1}^{p} R_{i, t}\left(\frac{Y_{t}^{P}}{Y_{t}}\right)^{\varepsilon_{i}}-\sum_{j=1}^{q} E_{j, t}\left(\frac{Y_{t}^{P}}{Y_{t}}\right)^{\beta_{j}} .
$$

Strukturalny deficyt budżetowy zapisać można w postaci, w której wysokość deficytu uzależniona jest od wysokości luki produktowej. Logarytmując obie strony równania (271) otrzymuje się:

$\ln R_{i, t}^{S}-\ln R_{i, t}=\varepsilon_{i}\left(\ln Y_{t}^{P}-\ln Y_{t}\right)$,

czyli:

$\ln R_{i, t}^{S}-\ln R_{i, t}=-\varepsilon_{i}\left(\ln Y_{t}-\ln Y_{t}^{P}\right)$.

Różnica logarytmów w przybliżeniu równa się procentowej różnicy, zatem:

$$
\frac{R_{i, t}^{S}-R_{i, t}}{R_{i, t}}=-\varepsilon_{i} \frac{Y_{t}-Y_{t}^{P}}{Y_{t}^{P}} .
$$

Uwzględniając, że luka produktowa określona jest wzorem:

$\widetilde{\mathrm{y}}_{\mathrm{t}}=\frac{Y_{t}-Y_{t}^{P}}{Y_{t}^{P}}$

otrzymuje się:

$$
\frac{R_{i, t}^{S}-R_{i, t}}{R_{i, t}}=-\varepsilon_{i} \widetilde{\mathrm{y}}_{\mathrm{t}} .
$$


Tak więc:

$R_{i, t}^{S}=R_{i, t}-R_{i, t} \varepsilon_{i} \tilde{\mathrm{y}}_{\mathrm{t}}$.

Analogiczne zależności dotyczą wydatków budżetowych. Zatem na podstawie równania (272) otrzymuje się:

$E_{j, t}^{S}=E_{j, t}-E_{j, t} \beta_{j} \widetilde{\mathrm{y}}_{\mathrm{t}}$.

Deficyt strukturalny można więc określić wzorem:

$B B_{t}^{S}=\sum_{i=1}^{p} R_{i, t}-\sum_{j=1}^{q} E_{j, t}-\left(\sum_{i=1}^{p} R_{i, t} \varepsilon_{i} \widetilde{\mathrm{y}}_{\mathrm{t}}-\sum_{j=1}^{q} E_{j, t} \beta_{j} \widetilde{\mathrm{y}}_{\mathrm{t}}\right)$.

Deficyt strukturalny wyznaczony na podstawie równania (283) zawiera wszystkie nieregularne czynniki, które nie zależą od fluktuacji gospodarczych (por. Brandner, Diebalek, Schuberth, 1998). Zatem, jak wskazuje Momigliano (1999), deficyt strukturalny wyznaczony na podstawie przedstawionej metody jest synonimem deficytu skorygowanego o wahania cykliczne (deficytu skorygowanego o efekty wahań PKB).

Cykliczne dochody $\left(R_{i, t}^{C}\right)$ i wydatki publiczne $\left(E_{i, t}^{C}\right)$ określa się jako wynikające z odchyleń PKB od poziomu potencjalnego różnice między wielkościami rzeczywistymi a strukturalnymi, czyli:

$$
\begin{aligned}
& R_{i, t}^{C}=R_{i, t}-R_{i, t}^{S}=R_{i, t}\left[1-\left(\frac{Y_{t}^{P}}{Y_{t}}\right)^{\varepsilon_{i}}\right], \\
& E_{j, t}^{C}=E_{j, t}-E_{j, t}^{S}=E_{j, t}\left[1-\left(\frac{Y_{t}^{P}}{Y_{t}}\right)^{\beta_{j}}\right] .
\end{aligned}
$$

Na podstawie równań (284) i (285) otrzymuje się, że cykliczny komponent salda budżetowego $\left(B B_{t}^{C}\right)$, stanowiący różnicę miedzy saldem rzeczywistym a strukturalnym, określa wzór postaci:

$B B_{t}^{C}=\sum_{i=1}^{p} R_{i, t}\left[1-\left(\frac{Y_{t}^{P}}{Y_{t}}\right)^{\varepsilon_{i}}\right]-\sum_{j=1}^{q} E_{j, t}\left[1-\left(\frac{Y_{t}^{P}}{Y_{t}}\right)^{\beta_{j}}\right]$.

Zastosowanie równań (281) i (282) umożliwia uproszczenie zapisu cyklicznych dochodów i wydatków budżetowych. Dochody i wydatki cykliczne definiowane są jako różnice między wielkościami rzeczywistymi a strukturalnymi, zatem na podstawie równań (281) oraz (282) otrzymuje się:

$$
\begin{aligned}
& R_{i, t}^{C}=R_{i, t} \varepsilon_{i} \widetilde{\mathrm{y}}_{\mathrm{t}}, \\
& E_{i, t}^{C}=E_{i, t} \beta_{i} \widetilde{\mathrm{y}}_{\mathrm{t}},
\end{aligned}
$$


czyli:

$$
B B_{t}^{C}=\left(\sum_{i=1}^{p} R_{i, t} \varepsilon_{i}-\sum_{j=1}^{q} E_{j, t} \beta_{j}\right) \widetilde{\mathrm{y}}_{\mathrm{t}} .
$$

$Z$ równania (289) wynika, że wysokość cyklicznego deficytu budżetowego uzależniona jest od kształtowania się luki produktowej oraz krótkookresowych elastyczności dochodów i wydatków budżetowych.

W niniejszej pracy zastosowano dwustopniową, wykorzystującą analizę systemu podatkowego, metodę szacowania elastyczności dochodów publicznych względem PKB. Elastyczność dochodu budżetowego względem PKB rozbija się w niej na dwa komponenty - elastyczność bazy podatkowej względem PKB i elastyczność wysokości wpływów podatkowych względem bazy podatkowej (por. Coricelli, Ercolani, 2002). Kształtowanie się elastyczności wpływów podatkowych względem bazy podatkowej uzależnione jest od wysokości przeciętnych i krańcowych stawek podatkowych. Elastyczność bazy podatkowej względem PKB wyznacza się natomiast na podstawie estymacji. Przy czym zamiast bazy podatkowej danego podatku z reguły stosuje się zmienną makroekonomiczną stanowiącą z jednej strony przybliżenie bazy podatkowej, a z drugiej strony bezpośrednio uzależnioną od kształtowania się PKB. Im wybrana zmienna makroekonomiczna stanowi dokładniejsze przybliżenie bazy podatkowej i im jest ściślej powiązana z PKB, tym dokładniejsze jest szacowanie elastyczności podatków na podstawie analizy rozwiązań prawnych (por. Momigliano, Staderini, 1999).

\subsection{Komponenty cykliczne dochodów oraz wydatków publicznych}

Do dochodów sektora finansów publicznych wrażliwych na wahania koniunktury zalicza się podatek dochodowy od osób fizycznych, podatek dochodowy od osób prawnych, dochody funduszy celowych ze składek oraz podatki pośrednie (por. np. de Cos, 1999; Momigliano, Staderini, 1999).

Krótkookresową elastyczność wpływów podatkowych z PIT względem PKB wyznaczono przy założeniu, że rozkład wynagrodzeń wśród pracowników nowo zatrudnionych jest taki sam, jak w przypadku dotychczasowych pracowników (por. Giorno, Richardson, Roseveare, van den Noord, 1995). W rezultacie otrzymuje się, że wrażliwość podatku PIT na wahania koniunktury uzależniona jest od siły reakcji zatrudnienia oraz stawki płac na fluktuacje produkcji ${ }^{15}$ :

${ }^{15} \mathrm{~W}$ pracy analizowany jest główny składnik bazy podatkowej podatku PIT rozliczanego na zasadach ogólnych, czyli dochody z wynagrodzeń. Na bazę podatkową składają się również inne elementy, m.in. emerytury, renty, dochody z umów zleceń i o dzieło (szerzej na temat bardziej szczegółowej dekompozycji elastyczności wpływów z PIT względem PKB (por. Krajewski, 2005). 
$\varepsilon_{P I T, Y}=\frac{\partial P I T}{\partial Y} \frac{Y}{P I T}=\left(\frac{\partial p i t}{\partial w} \frac{w}{p i t}\right)\left(\frac{\partial w}{\partial Y} \frac{Y}{w}\right)+\frac{\partial L}{\partial Y} \frac{Y}{L}$,

gdzie:

$\varepsilon_{P I T, Y}-$ krótkookresowa elastyczność wpływów z PIT względem PKB,

PIT - wpływy z podatku dochodowego od osób fizycznych, bez opcji podatkowej ${ }^{16}$,

pit $=\frac{P I T}{L}$.

Przybliżenie krótkookresowej elastyczności liczby podatników względem PKB stanowi zatem krótkookresowa elastyczność zatrudnienia względem PKB $\left(\frac{\partial L}{\partial Y} \frac{Y}{L}\right)$. Przybliżeniem krótkookresowej elastyczności przeciętnego dochodu objętego podatkiem względem PKB jest natomiast krótkookresowa elastyczność przeciętnej stawki płac względem PKB $\left(\frac{\partial w}{\partial Y} \frac{Y}{w}\right)$.

Elastyczność wpływów z PIT przypadających na jednego podatnika względem przeciętnego wynagrodzenia $\left(\frac{\partial p i t}{\partial w} \frac{w}{p i t}\right)$ wyznaczyć można na podstawie systemu podatkowego. Im większe różnice między krańcowymi a przeciętnymi stawkami podatkowymi, tym silniejszy wpływ wahań przeciętnej stawki płac na fluktuacje wpływów z podatku PIT. Zatem wraz ze wzrostem progresji podatkowej rośnie elastyczność wpływów z PIT przypadających na jednego podatnika względem przeciętnego wynagrodzenia.

Krótkookresową elastyczność wpływów z PIT przypadających na jednego podatnika oszacowano poprzez obliczenie dla każdego z przedziałów podatkowych stosunku krańcowej stopy podatkowej do przeciętnej stopy podatkowej, a następnie wyciągnięcie średniej ważonej, gdzie wagami są wysokości wpływów podatkowych uzyskanych z poszczególnych przedziałów podatkowych (por. Giorno, Richardson, Roseveare, van den Noord, 1995):

$\frac{\partial p i t}{\partial w} \frac{w}{p i t}=\sum_{j=1}^{n} \frac{P I T_{j}}{P I T} \frac{M T R_{j}}{A T R_{j}}$

${ }^{16} \mathrm{~W}$ podatku PIT wyodrębnić można podatek rozliczany na zasadach ogólnych oraz tzw. opcję podatkową, czyli podatek liniowy płacony przez przedsiębiorców. Reakcja na wahania koniunktury wpływów budżetowych z opcji podatkowej jest odmienna niż w przypadku podatku rozliczanego na zasadach ogólnych, ponieważ opcja podatkowa nie jest systemem progresywnym, a jej baza podatkowa nie jest uzależniona od poziomu wynagrodzeń, lecz od zysków przedsiębiorstw. Z tych względów wpływy z opcji podatkowej zostały wyłączone z podatku PIT i analizowane łącznie z podatkiem CIT. 
gdzie:

$P I T_{j}$ - wpływy podatkowe od podatników należących do j-tego przedziału podatkowego,

$M T R_{j}$ - krańcowa stopa podatkowa dla $j$-tego przedziału podatkowego,

$A T R_{j}$ - efektywna (przeciętna) stopa podatkowa dla $j$-tego przedziału podatkowego.



Rysunek 13. Stosunek krańcowych do przeciętnych stóp podatkowych w podatku PIT rozliczanym na zasadach ogólnych w latach 1995-2010

Źródło: opracowanie własne na podstawie danych Ministerstwa Finansów.

Na rysunku 13 ukazano kształtowanie się relacji krańcowych do przeciętnych stóp podatkowych w poszczególnych przedziałach podatkowych. Najwyższa relacja krańcowych do przeciętnych stóp podatkowych w ciągu prawie całego badanego okresu występowała w drugim przedziale podatkowym. Kształtowanie się krótkookresowej elastyczności wpływów z PIT przypadających na jednego podatnika względem przeciętnego wynagrodzenia, wyznaczonej na podstawie równania (292) w oparciu o wyznaczone relacje krańcowych do przeciętnych stóp podatkowych, przedstawione zostało na rysunku 14. Elastyczność wpływów z PIT przypadających na jednego podatnika względem średniego poziomu wynagrodzeń była najwyższa w 1996 roku, gdy występowały stawki podatkowe 21, 33 i 45\%. Natomiast jej najniższy poziom miał miejsce w roku 2009, po zlikwidowaniu trzeciego przedziału podatkowego. Średnia wartość analizowanej elastyczności w badanym okresie wynosiła 1,44. 


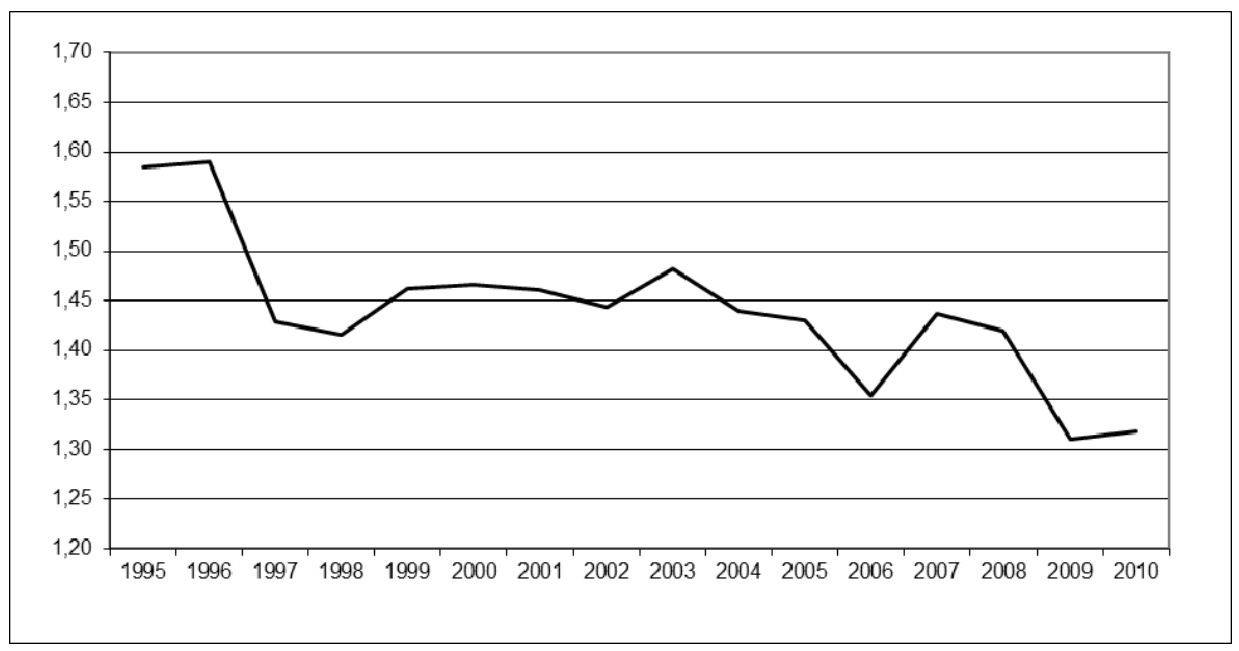

Rysunek 14. Krótkookresowa elastyczność wpływów z PIT przypadających na jednego podatnika względem przeciętnego wynagrodzenia w latach 1995-2010

Źródło: Opracowanie własne na podstawie danych Ministerstwa Finansów.

Jak wynika z równania (290), na poziom krótkookresowej elastyczności wpływów z PIT względem PKB ma również wpływ siła reakcji zatrudnienia i wynagrodzeń na wahania koniunktury. Krótkookresowa elastyczność zatrudnienia względem PKB wyznaczona została (podobnie jak np. w pracy Czyżewskiego i Łapińskiej-Sobczak, 2001) na podstawie równania:

$\stackrel{\circ}{L}_{t, i}=\alpha_{0}+\alpha_{1} \stackrel{\circ}{Y}_{t, i}+\xi_{t, i}$,

gdzie $\stackrel{\circ}{L}_{t, i}$ oraz $\stackrel{\circ}{Y}_{t, i}$ oznaczają tempo wzrostu liczby pracujących (wg BAEL) oraz realne tempo wzrostu PKB w roku $t \mathrm{w} i$-tym kwartale w stosunku do analogicznego kwartału roku poprzedniego (dane GUS) ${ }^{17}$.

Na podstawie testu stacjonarności ADF otrzymano, że przy poziomie istotności 5\% nie ma podstaw do odrzucenia hipotezy, że tempo wzrostu liczby pracujących jest zmienną niestacjonarną (zmienną $\mathrm{I}(1))^{18}$. Zatem w celu zapewnienia stacjonarności zmiennych zależność określoną równaniem (293) oszacowano na pierwszych przyrostach:

$\Delta \stackrel{\circ}{L}_{t, i}=\alpha_{0}+\alpha_{1} \Delta \stackrel{\circ}{Y}_{t, i}+\xi_{t, i}$,

${ }^{17}$ Analogiczne oznaczenia temp wzrostu przyjęto w dalszej części opracowania.

${ }^{18}$ Możliwość występowania niestacjonarności tempa wzrostu liczby pracujących w gospodarce polskiej jest zjawiskiem nietypowym i trudnym do wyjaśnienia na gruncie teoretycznym. Jednocześnie wyniki testu KPSS wskazują, że przy poziomie istotności 5\% nie ma również podstaw do odrzucenia hipotezy, że tempo wzrostu liczby pracujących jest zmienną stacjonarną. 
uzyskując metodą najmniejszych kwadratów następujące wyniki estymacji19:



Otrzymano więc oszacowanie krótkookresowej elastyczności zatrudnienia względem PKB znacznie niższe od jedności ${ }^{20}$. Fluktuacje PKB są zatem w pewnym stopniu absorbowane przez wahania wydajności pracy. Ograniczony wpływ wahań produkcji na kształtowanie się liczby pracujących można tłumaczyć m.in. występowaniem zjawiska ,chomikowania pracy” w przedsiębiorstwach i rozwiązaniami instytucjonalnymi prowadzącymi do wysokiego stopnia ochrony stosunku pracy (por. m.in. Tokarski, 2001; Lubiński, 2002).

W celu wyznaczenia krótkookresowej elastyczności stawki płac względem produkcji oszacowano parametry równania:

$$
\stackrel{\circ}{w}_{t, i}=\alpha_{0}+\alpha_{1} \stackrel{\circ}{Y}_{t, i}+\xi_{t, i},
$$

gdzie $w_{t, i}$ oznacza tempo wzrostu przeciętnego miesięcznego wynagrodzenia realnego brutto w gospodarce narodowej ogółem (dane GUS).

Przeprowadzona klasyczną metodą najmniejszych kwadratów estymacja równania (295) wskazała na występowanie silnej autokorelacji składnika losowego. Zatem równanie (295) oszacowano przy założeniu, że składnik losowy jest postaci $\xi_{t, i}=\rho \xi_{t-1,4}+\eta_{t, i}$, dla $i=1, \xi_{t, i}=\rho \xi_{t, i-1}+\eta_{t, i}$, dla $i=2,3,4^{21}$, otrzymując następujące wyniki estymacji:

$$
\stackrel{\circ}{w}, i_{(1,060)}^{0,007}+\underset{(4,033)}{0,558 \dot{Y}_{t, i}} \quad R^{2}=0,635 \quad D W=1,901
$$

Opierając się na przedstawionych powyżej oszacowaniach, na podstawie równania (290) uzyskuje się średnią w badanym okresie wartość krótkookresowej elastyczności wpływów z PIT względem PKB równą 1,150. W tabeli 9 ukazano kształtowanie się analizowanej elastyczności w poszczególnych latach ${ }^{22}$.

\footnotetext{
${ }^{19}$ Pod oszacowaniami w nawiasach podano wartości statystyk t-Studenta.

${ }^{20}$ Jednocześnie otrzymane oszacowanie jest w sposób statystycznie istotny niższe od jedności, przy poziomie istotności 5\%.

${ }^{21}$ Ze względu na występowanie autokorelacji składnika losowego analogiczne założenie dotyczące składnika losowego przyjęto w przypadku estymacji elastyczności zysków oraz konsumpcji prywatnej względem PKB, przedstawionych w dalszej części rozdziału.

${ }^{22}$ Różnice w wartościach elastyczności w poszczególnych latach wynikają z faktu, że w badanym okresie zmianom ulegały relacje krańcowych do przeciętnych stóp podatkowych. Warto przy tym zaznaczyć, że zmianom w ramach cyklu podlegać może również elastyczność bazy podatkowej PIT względem PKB. Według Lubińskiego (2002) w okresie wychodzenia z recesji zazwyczaj ma miejsce szybki wzrost wydajności pracy przy stosunkowo stabilnych płacach, co powoduje, że koszty płacowe mogą nie rosnąć, natomiast w dalszej fazie wzrostu osłabieniu ulega tempo wzrostu wydajności pracy i nasila się wzrost płac. Oznacza to, że w początkowej fazie ożywienia baza podatkowa PIT może w mniejszym stopniu reagować na wzrost PKB niż w końcowej fazie ożywienia.
} 
Tabela 9. Krótkookresowa elastyczność wpływów z PIT względem PKB w latach 1995-2010

\begin{tabular}{|c|c|}
\hline Rok & $\begin{array}{c}\text { Elastyczność wpływów z PIT } \\
\text { względem PKB }\end{array}$ \\
\hline 1995 & 1,230 \\
\hline 1996 & 1,234 \\
\hline 1997 & 1,143 \\
\hline 1998 & 1,136 \\
\hline 1999 & 1,162 \\
\hline 2000 & 1,164 \\
\hline 2001 & 1,161 \\
\hline 2002 & 1,152 \\
\hline 2003 & 1,173 \\
\hline 2004 & 1,149 \\
\hline 2005 & 1,144 \\
\hline 2006 & 1,102 \\
\hline 2007 & 1,148 \\
\hline 2008 & 1,138 \\
\hline 2009 & 1,077 \\
\hline 2010 & 1,082 \\
\hline
\end{tabular}

Źródło: opracowanie własne na podstawie danych GUS i Ministerstwa Finansów.

W przypadku składek na fundusze celowe wysokość wpływów zmienia się proporcjonalnie do funduszu wynagrodzeńn ${ }^{23}$. W rezultacie wzór na krótkookresową elastyczność dochodów funduszy celowych ze składek względem PKB $\left(\varepsilon_{S S C, Y}\right)$ przyjmuje postać:

$\varepsilon_{S S C, Y}=\frac{\partial S S C}{\partial Y} \frac{Y}{S S C}=\varepsilon_{L, Y}+\varepsilon_{w, Y}$,

gdzie SSC oznacza dochody funduszy celowych ze składek.

Jednocześnie w różnych fazach cyklu koniunkturalnego następują zmiany skali funkcjonowania szarej strefy.

${ }^{23}$ Poziom, od którego przestaje się płacić składki na ubezpieczenie emerytalne i rentowe (tzw. limit 30-krotności) jest zależny od średniego poziomu wynagrodzeń, a więc procentowy udział funduszu wynagrodzeń, od którego nie płaci się części składek nie zmienia się wraz z fluktuacjami gospodarczymi i nie wpływa na elastyczność składek względem funduszu wynagrodzeń. 
Krótkookresowa elastyczność dochodów funduszy celowych ze składek względem PKB jest zatem uzależniona od reakcji funduszu wynagrodzeń na wahania koniunktury. Przyjmując wcześniej wyznaczone oszacowania krótkookresowej elastyczności zatrudnienia i stawki płac względem PKB uzyskuje się krótkookresową elastyczność dochodów funduszy celowych ze składek względem PKB wynoszącą 0,904 .

Ze względu na niewystępowanie progresji podatkowej w podatku CIT, krótkookresowa elastyczność wpływów z tego podatku względem PKB $\left(\varepsilon_{C I T, Y}\right)$ jest uzależniona jedynie od elastyczności bazy podatkowej, tj. zysków przedsiębiorstw $(\pi)$, czyli dana wzorem:

$$
\varepsilon_{C I T, Y}=\frac{\partial C I T}{\partial Y} \frac{Y}{C I T}=\frac{\partial \pi}{\partial Y} \frac{Y}{\pi}
$$

gdzie CIT oznacza wpływy z podatku dochodowego od osób prawnych (wraz $\mathrm{z}$ opcją podatkową w podatku dochodowym od osób fizycznych ${ }^{24}$.

W celu wyznaczenia krótkookresowej elastyczności zysków przedsiębiorstw względem PKB dokonano estymacji równania:

$$
\stackrel{\circ}{\pi}_{t, i}=\alpha_{0}+\alpha_{1} \stackrel{\circ}{Y}_{t, i}+\xi_{t, i},
$$

gdzie $\dot{\pi}_{t, i}$ oznacza realne tempo wzrostu zysków brutto przedsiębiorstw (dane GUS $)^{25}$, otrzymując następujące oszacowania parametrów:

$$
\dot{\pi}_{t, i}=\underset{(-0,023)}{0,007+\underset{(4,237)}{1,188 \dot{Y}_{t, i}}} R^{2}=0,666 \quad D W=2,162
$$

Otrzymane oszacowanie krótkookresowej elastyczności wpływów z CIT względem PKB, mimo braku występowanie progresji w tym podatku, jest nieznacznie wyższe niż w przypadku PIT, co wynika z relatywnie silnej reakcji zysków na wahania koniunktury ${ }^{26}$.

${ }^{24}$ Założono zatem, że wpływy z CIT są proporcjonalne do bazy podatkowej. Warto przy tym zaznaczyć, że regulowanie zobowiązań podatkowych przez przedsiębiorstwa ma z reguły charakter procykliczny. Narosłe w czasie osłabienia aktywności gospodarczej zobowiązania podatkowe są spłacane w czasie ożywienia gospodarczego, gdy sytuacja finansowa przedsiębiorstwa poprawia się. Efekt ten zwiększa procykliczność wpływów z podatku CIT. Z drugiej strony przenoszenie straty powstałej podczas pogorszenia koniunktury na okres ożywienia gospodarczego zmniejsza procykliczność wpływów z podatku CIT. Jak wskazuje van den Noord (2000) trudno jednoznacznie ocenić, który z powyższych efektów ma większy wpływ na kształtowanie się dochodów budżetowych z CIT, dlatego z reguły zakłada się, że efektywna stopa podatkowa podatku CIT nie zmienia się w trakcie cyklu koniunkturalnego.

${ }^{25}$ Tempo wzrostu sumy wyników finansowych brutto przedsiębiorstw osiągających zyski, urealnione deflatorem PKB.

${ }^{26}$ Jednocześnie jednak należy podkreślić, że zarówno elastyczność względem PKB wpływów zarówno z podatku PIT, podatku CIT, jak i składek nie jest, przy założonym poziomie istotności 5\%, w sposób statystycznie istotna różna od jedności. 
Oddziaływanie wahań koniunktury na zyski przedsiębiorstw, stanowiące przybliżenie bazy podatkowej podatku CIT, wyznaczyć można również na podstawie funkcji produkcji. Zakładając, że funkcja produkcji jest funkcją Cobba-Douglasa o stałych efektach skali i elastyczności produkcji względem kapitału równej $\theta$, a czynniki produkcji są opłacane zgodnie z ich produktami krańcowymi otrzymuje się:

$$
\frac{\partial \pi}{\partial Y} \frac{Y}{\pi}=\frac{1}{\theta}+\frac{1-\theta}{\theta}\left(\frac{\partial L}{\partial Y} \frac{Y}{L}+\frac{\partial w}{\partial Y} \frac{Y}{w}\right) .
$$

Dla $\theta=0,41$, czyli wartości elastyczności produkcji względem kapitału oszacowanej w niniejszej pracy (por. rozdział trzeci), otrzymano elastyczność bazy podatkowej CIT względem PKB równą 1,138, w więc zbliżoną do uzyskanej na podstawie estymacji parametrów równania $(298)^{27}$.

Oprócz podatków bezpośrednich jako automatyczny stabilizator koniunktury działają również podatki pośrednie. Zazwyczaj zakłada się, że występuje jednostkowa elastyczność wpływów z podatków pośrednich względem bazy podatkowej (por. van den Noord, 2000). Mimo że wysokość wpływów z podatków pośrednich jest zazwyczaj proporcjonalna do wysokości bazy podatkowej, w niektórych krajach występują wyższe stopy opodatkowania dóbr luksusowych o wysokiej elastyczności dochodowej. W takim przypadku elastyczność wpływów z podatków pośrednich względem bazy podatkowej może być wyższa od jedności. Ze względu jednak na to, że określenie różnicy pomiędzy elastycznością dochodową produktów objętych stawką 22\% i produktów objętych niższymi stawkami VAT jest trudne do precyzyjnego oszacowania, założono jednostkową elastyczność wpływów z VAT względem bazy podatkowej. W celu oszacowania efektywności podatków pośrednich jako automatycznego stabilizatora koniunktury konieczne jest również wyznaczenie krótkookresowej elastyczności bazy podatkowej podatków pośrednich względem PKB. Na bazę podatkową podatków pośrednich składa się spożycie indywidualne $(C)$ oraz ta część zakupów rządowych, która objęta jest podatkiem VAT $\left(G^{V A T}\right)^{28}$, zatem krótkookresowa elastyczność wpływów z podatków pośrednich $\left(\varepsilon_{I T, Y}\right)$ dana jest wzorem:

$$
\varepsilon_{I T, Y}=\frac{\partial I T}{\partial Y} \frac{Y}{I T}=\frac{C}{C+G^{V A T}}\left(\frac{\partial C}{\partial Y} \frac{Y}{C}\right)+\frac{G^{V A T}}{C+G^{V A T}}\left(\frac{\partial G^{V A T}}{\partial Y} \frac{Y}{G^{V A T}}\right),
$$

gdzie $I T$ oznacza wpływy z podatków pośrednich.

${ }^{27}$ Jak wspomniano w rozdziale trzecim, poszczególne oszacowania elastyczności produkcji względem kapitału dla Polski znacząco się różnią, zawierając się w przedziale $0,25-0,5$ (por. Welfe, 2007). Przyjmując wcześniej wyznaczone krótkookresowe elastyczności zatrudnienia i wynagrodzeń względem PKB oraz udział dochodów z kapitału równy 0,25 otrzymuje się krótkookresową elastyczność zysków względem PKB wynoszącą 1,288. Natomiast dla $\theta=0,5$ wynosi ona 1,096 . Zatem niezależnie od wartości parametru $\theta$ uzyskuje się wyniki wyższe od jedności, nie odbiegające znacząco od otrzymanych na podstawie estymacji parametrów równania (298).

${ }^{28}$ Wydatki rządowe pomniejszone o wydatki na wynagrodzenia. 
W literaturze przyjmuje się zazwyczaj, że wysokość spożycia zbiorowego nie zależy w sposób automatyczny od wahań PKB (jest uzależniona od polityki gospodarczej państwa) ${ }^{29}$. Natomiast krótkookresowa elastyczność konsumpcji prywatnej względem PKB oszacowana została na podstawie estymacji parametrów równania:

$$
\stackrel{\circ}{C}_{t, i}=\alpha_{0}+\alpha_{1} \stackrel{\circ}{Y}_{t, i}+\xi_{t, i} \text {, }
$$

gdzie $\stackrel{\circ}{C}_{t, i}$ oznacza tempo wzrostu spożycia indywidualnego (dane GUS). W wyniku estymacji uzyskano następujące oszacowania parametrów:

$$
\stackrel{\circ}{C}_{t, i}=\underset{(1,540)}{0,010}+\underset{(5,832)}{0,705 \dot{Y}_{t, i}} \quad R^{2}=0,723 \quad D W=2,042
$$

Otrzymana krótkookresowa elastyczność konsumpcji prywatnej względem PKB jest niższa od jedności (wynosi 0,70), czyli wahania konsumpcji w ramach cyklu są relatywnie mniejsze niż wahania PKB. Na podstawie otrzymanej elastyczności spożycia indywidualnego względem PKB i uwzględniając średni w analizowanym okresie udział spożycia indywidualnego w bazie podatkowej VAT otrzymuje się krótkookresową elastyczność spożycia ogółem względem PKB równą 0,573. Oszacowanie elastyczności jest przy tym, odmiennie niż w przypadku wcześniej analizowanych podatków, w sposób statystycznie istotny niższe od jedności ${ }^{30}$.

Elastyczności poszczególnych podatków względem PKB zostały obliczone przy założeniu, że zależności pomiędzy PKB a zmiennymi stanowiącymi przybliżenie baz podatkowych kształtują się na stałym poziomie w ramach całego badanego okresu. Uchylając to założenie dokonano estymacji parametrów równań (294), (295), (298) oraz (301) osobno dla dwóch podokresów, tj. okresu przed wejściem i po wejściu Polski do Unii Europejskiej. Uzyskane oszacowania elastyczności zostały przedstawione w tabeli 10.

Tabela 10. Oszacowania krótkookresowych elastyczności względem PKB zmiennych wpływających na kształtowanie się baz podatkowych przed wstąpieniem i po wstąpieniu Polski do Unii Europejskiej

\begin{tabular}{|l|c|c|}
\hline \multirow{2}{*}{ Zmienna } & \multicolumn{2}{|c|}{ Oszacowanie elastyczności } \\
\cline { 2 - 3 } & przed wstąpieniem do UE & po wstąpieniu do UE \\
\hline Zatrudnienie & 0,356 & 0,372 \\
\hline Stawka płac & 0,537 & 0,438 \\
\hline Zyski & 0,925 & 1,264 \\
\hline Konsumpcja prywatna & 0,734 & 0,654 \\
\hline
\end{tabular}

Źródło: opracowanie własne na podstawie danych GUS.

${ }^{29}$ Zazwyczaj przyjmuje się, że spośród wydatków publicznych jedynie część transferów (tj. wydatki na pasywne formy przeciwdziałania bezrobociu) jest bezpośrednio powiązana ze stanem koniunktury (por. np., Momigliano, Staderini, 1999; European Commission, 2000; van den Noord, 2000). Jeżeli zakłada się, że z wahaniami koniunktury związane są również inne wydatki publiczne, wówczas założenie to dotyczy z reguły innych transferów, np. wydatków socjalnych (por. Chak, 2002).

${ }^{30}$ Przy poziomie istotności 5\%. 
Oszacowania parametrów kształtują się o obydwu podokresach na zbliżonym poziomie i nie są $\mathrm{w}$ statystycznie istotny sposób różne od siebie. $\mathrm{Z}$ tego względu w dalszej części badania oparto się na oszacowaniach elastyczności dochodów publicznych względem PKB wyznaczonych na podstawie całej badanej próby.

Wśród wydatków publicznych od fluktuacji gospodarczych w sposób bezpośredni uzależnione są wydatki związane z bezrobociem. Wraz z osłabieniem aktywności gospodarczej maleje zatrudnienie i rośnie bezrobocie, co prowadzi do zwiększenia się wydatków publicznych na zasiłki dla bezrobotnych. Oprócz wydatków związanych $z$ bezrobociem na wahania koniunktury reagować mogą również inne wydatki, np. wydatki socjalne lub wydatki na służbę zdrowia. Jednakże badania empiryczne wskazują, że trudno jest określić stabilną zależność między tymi wydatkami ( $\mathrm{tj}$. wydatkami innymi niż wydatki związane $\mathrm{z}$ bezrobociem) a luką produktową (por. European Commission, 2000). Dlatego zazwyczaj przyjmuje się, że jedynymi wydatkami automatycznie reagującymi na zmiany koniunktury są wydatki związane z wysokością bezrobocia - wydatki na pasywne formy przeciwdziałania bezrobociu (por. np. van den Noord, 2000) ${ }^{31}$.

Do wydatków na pasywne formy przeciwdziałania bezrobociu zalicza się zasiłki dla bezrobotnych, zasiłki przedemerytalne i świadczenia przedemerytalne. Wysokość wydatków publicznych na pasywne formy przeciwdziałania bezrobociu zależy od liczby bezrobotnych $(U)$ i średniej wysokości świadczenia przypadającego na jednego bezrobotnego $(u b)$. W rezultacie krótkookresową elastyczność wydatków na pasywne formy przeciwdziałania bezrobociu względem PKB $\left(\beta_{U B, Y}\right)$ wyznaczyć można na podstawie wzoru:

$$
\beta_{U B, Y}=\frac{\partial U}{\partial Y} \frac{Y}{U}+\frac{\partial u b}{\partial Y} \frac{Y}{u b} .
$$

Średnia wysokość zasiłku nie jest uzależniona od fluktuacji gospodarczych, lecz wynika z przepisów rynku pracy. A zatem wysokość wydatków publicznych na pasywne formy przeciwdziałania bezrobociu jest proporcjonalna do wysokości bezrobocia. Wzór na elastyczność upraszcza się więc do postaci:

$$
\beta_{U B, Y}=\frac{\partial U}{\partial Y} \frac{Y}{U}
$$

czyli:

$\beta_{U B, Y}=\frac{\partial L^{S}-\partial L}{\partial Y} \frac{Y}{U}$,

${ }^{31}$ Choć np. Chalk (2002) do wydatków automatycznie reagujących na wahania koniunktury oprócz wydatków bezpośrednio związanych z bezrobociem zalicza również inne wydatki budżetowe, m.in. wydatki socjalne. 
gdzie $L^{S}$ oznacza siłę roboczą. W rezultacie z przekształceń równania (304) wynika, że elastyczność wydatków na pasywne formy przeciwdziałania bezrobociu względem PKB jest uzależniona od poziomu stopy bezrobocia $(u)$ :

$$
\beta_{U B, Y}=-\left(\frac{\partial L}{\partial Y} \frac{Y}{L}\right)\left[\frac{1-\left(\frac{\partial L^{S}}{\partial L} \frac{L}{L^{S}}\right)}{u}-1\right] .
$$

Przy założeniu, że wysokość siły roboczej nie reaguje na wahania koniunktury i związane z nimi wahania zatrudnienia (krótkookresowa elastyczność siły roboczej względem zatrudnienia jest równa zero) ${ }^{32}$ otrzymuje się zatem:

$\beta_{U B, Y}=-\frac{1-u}{u} \varepsilon_{L, Y}$.

Oszacowanie krótkookresowej elastyczności zatrudnienia względem PKB przyjęto na poziomie analogicznym jak w przypadku analizy dochodów budżetowych. Uwzględniając średni poziom stopy bezrobocia w analizowanym okresie ${ }^{33}$, na podstawie równania (306) otrzymuje się, że średni poziom krótkookresowej elastyczności wydatków na pasywne formy przeciwdziałania bezrobociu względem PKB w latach 1995-2010 wynosił -2,176, a zatem w ujęciu bezwzględnym był znacznie wyższy od jedności ${ }^{34}$. Jednocześnie warto zaznaczyć, że ze względu na fakt, iż stopa bezrobocia w analizowanym okresie ulegała znacznym wahaniom (por. np. Jarmołowicz, Knapińska, 2011, Jarmołowicz, Woźniak-Jęchorek, 2011), istotnym fluktuacjom ulegała również krótkookresowa elastyczność wydatków na pasywne formy przeciwdziałania bezrobociu względem PKB, co obrazują dane zamieszczone w tabeli 11.

Jak wynika z równania (289), na kształtowania się cyklicznych komponentów dochodów i wydatków publicznych, oprócz krótkookresowych elastyczności wpływów podatkowych względem PKB, wpływa również wysokość luki produktowej w danym okresie.

32 Wyniki estymacji równania $\stackrel{\circ}{L_{t, i}^{S}}=\alpha_{0}+\alpha_{1}{\stackrel{0}{L_{t, i}}}+\xi_{t, i}$ nie wskazują na występowanie statystycznie istotnej zależności między krótkookresowymi wahaniami zatrudnienia i siły roboczej.

${ }^{33}$ Stopa bezrobocia rejestrowanego, dane GUS. W ramach analizy wydatków na pasywne formy przeciwdziałania bezrobociu nie jest analizowana stopa bezrobocia wg. BAEL, ponieważ kształtowanie się stopy bezrobocia rejestrowanego ma większy wpływ na liczbę zasiłków dla bezrobotnych.

${ }^{34}$ Otrzymano ponadto, że elastyczność wydatków na pasywne formy przeciwdziałania bezrobociu względem PKB w ujęciu bezwzględnym w sposób statystycznie istotny różni się od jedności (przy założonym poziomie istotności 5\%). 
Tabela 11. Krótkookresowa elastyczność wydatków na pasywne formy przeciwdziałania bezrobociu względem PKB w latach 1995-2010

\begin{tabular}{|c|c|}
\hline Rok & $\begin{array}{c}\text { Elastyczność wydatków na pasywne formy } \\
\text { przeciwdziałania bezrobociu względem PKB }\end{array}$ \\
\hline 1995 & $-1,976$ \\
\hline 1996 & $-2,275$ \\
\hline 1997 & $-3,013$ \\
\hline 1998 & $-2,981$ \\
\hline 1999 & $-2,295$ \\
\hline 2000 & $-1,945$ \\
\hline 2001 & $-1,438$ \\
\hline 2002 & $-1,384$ \\
\hline 2003 & $-1,384$ \\
\hline 2004 & $-1,475$ \\
\hline 2005 & $-1,620$ \\
\hline 2006 & $-1,992$ \\
\hline 2007 & $-2,743$ \\
\hline 2008 & $-3,296$ \\
\hline 2009 & $-2,514$ \\
\hline 2010 & $-2,467$ \\
\hline & \\
\hline
\end{tabular}

Źródło: opracowanie własne na podstawie danych GUS.

Nie istnieje jedna ogólnie przyjęta metoda wyznaczania produkcji skorygowanej o wahania cykliczne. Trudności w ocenie poszczególnych metod wyznaczania PKB skorygowanego o wahania cykliczne wynikają stąd, że produkcja skorygowana o wahania cykliczne nie jest zmienną obserwowalną. Metody wyznaczania PKB skorygowanego o wahania cykliczne można podzielić na dwie podstawowe grupy:

- metody oparte na analizie szeregów czasowych PKB, wykorzystujące przede wszystkim filtry statystyczne,

- metody opierające się na funkcji produkcji i analizie wykorzystania czynników produkcji.

W pracy posłużono się filtrem statystycznym Christiano i Fitzgeralda (1999). Filtr Christiano-Fitzgeralda (CF) jest filtrem typu band pass, tj. filtrem pasmowo przepustowym. Jego zastosowanie umożliwia usunięcie $\mathrm{z}$ danych wejściowych długookresowego trendu stochastycznego, składników nieregularnych oraz sezonowych (por. Skrzypczyński, 2006). Dodatkowym atutem 
zastosowania filtra typu band pass jest możliwość określenia zakresu wahań wejściowego szeregu odpowiadającego przyjętemu a priori okresowi trwania cyklu koniunkturalnego (por. Skrzypczyński, 2010). Jednocześnie filtr CF generuje oczekiwane rezultaty tylko wtedy, gdy proces generujący dane wejściowe jest procesem błądzenia losowego bez dryfu. W przeciwnym wypadku może natomiast generować cykle pozorne (por. Wośko, 2009). Dlatego w przypadku zmiennych niestacjonarnych przed zastosowaniem filtra CF konieczne jest przekształcenie ich do postaci błądzenia losowego bez dryfu.

W celu wyodrębnienia luki produktowej, oprócz filtra $\mathrm{CF}$, stosowane są także inne filtry statystyczne, m.in zaproponowane przez Hodricka i Prescotta (1980) oraz Baxter i Kinga (1995). Filtr Hodricka-Prescotta (HP), zaliczany do tzw. filtrów high pass, do niedawna był najpopularniejszą metodą transformacji wejściowego szeregu w celu uzyskania wahań o wysokiej częstotliwości. Jednak analizy właściwości tego filtra obnażyły wiele jego wad, do których zaliczyć można wysoką wrażliwość na zmiany wartości i dodawanie nowych obserwacji, a także generowanie cykli w przypadku, gdy wejściowy szereg nie charakteryzuje się cyklicznością (por. Pedregal, Young, 2001; Wośko, 2009). Wraz ze zbliżaniem się do końca próby średnia ważona coraz bardziej opiera się na wielkościach z wcześniejszych okresów. W przypadku ostatnich 3-4 obserwacji istnieje tendencja do eliminowania krótszych cykli koniunkturalnych niż wynikałoby to z wartości parametru wygładzenia (por. McMorrow, Roger, 2001). Ponadto filtr HP zastosowany dla danych oczyszczonych z sezonowości i długookresowego trendu generuje szereg zawierający oprócz wahań koniunkturalnych także fluktuacje nieregularne (por. Skrzypczyński, 2006). Natomiast filtr Baxter-Kinga (BK), zaliczany jest do filtrów pasmowych, podobnie jak w przypadku filtra $\mathrm{CF}$, może generować cykle pozorne, jeśli szereg wejściowy jest generowany przez proces niestacjonarny. W przeciwieństwie do filtra opracowanego przez Christiano i Fitzgeralda filtr BK jest jednak filtrem symetrycznym, co powoduje, iż $\mathrm{w}$ wyniku jego zastosowania traci się $n$ początkowych i końcowych obserwacji ${ }^{35}$.

Powyższy krótki przegląd właściwości poszczególnych filtrów może wskazywać na wyższość filtra CF nad alternatywnymi metodami filtracji. Trzeba jednak zaznaczyć, że filtracja, choć jest powszechnie stosowana do uzyskiwania szeregów reprezentujących cykliczne fluktuacje, to spotyka się również z krytyką, przede wszystkim ze względu na swój mechaniczny charakter. Alternatywną metodą wykorzystywaną w celu ekstrakcji komponentów cyklicznych są estymacje oparte na funkcji produkcji. Zaletą wyznaczania produkcji potencjalnej na podstawie funkcji produkcji jest to, że opiera się na fundamentach ekonomicznych, co umożliwia ekonomiczną interpretację

\footnotetext{
${ }^{35}$ Wartość parametru $n$ jest ustalana a priori. Według Baxter i Kinga (1999) powinna stanowić równowartość 3 lat.
} 
uzyskanych wyników. Zarazem jednak wyniki otrzymane na podstawie funkcji produkcji zależą $\mathrm{w}$ znacznym stopniu od przyjętych założeń teoretycznych, w tym przede wszystkim założeń dotyczących postaci funkcji produkcji i sposobu definiowania naturalnej stopy bezrobocia ${ }^{36}$. $Z$ tego względu w niniejszym opracowaniu zastosowano metodę wyznaczania luki produktowej opartą na filtracji. Istnieje przy tym zazwyczaj silna korelacja między luką produktową otrzymaną na podstawie filtrów statystycznych i luką produktową otrzymaną na podstawie funkcji produkcji ${ }^{37}$.

W celu uzyskania luki produktowej w Polsce wykorzystano kwartalne dane dotyczące realnego PKB z lat 1995-2010 ${ }^{38}$. Dane zostały odsezonowane przy wykorzystaniu metody Census $\mathrm{X}-12^{39}$. Niestacjonarność szeregu czasowego realnego PKB została potwierdzona za pomocą testów ADF oraz KPSS ${ }^{40}$. Analizowany szereg czasowy zawiera w sobie długookresowy trend stochastyczny, zatem przed zastosowaniem filtra CF został on poddany procedurze usunięcia dryfu.

Kształtowanie się komponentów cyklicznych dochodów oraz wydatków publicznych, wyznaczonych w oparciu o lukę produktową oszacowaną na podstawie filtra CF oraz krótkookresowe elastyczności wpływów podatkowych i wydatków związanych $\mathrm{z}$ bezrobociem względem PKB, pokazane jest na rysunku 15.

${ }^{36}$ Wyznaczanie produkcji potencjalnej na podstawie funkcji produkcji ma ponadto w większym stopniu zastosowanie do badania inflacji niż do wyodrębniania deficytu strukturalnego (por. Momigliano i Staderini, 1999).

${ }^{37}$ Według obliczeń Komisji Europejskiej we wszystkich krajach Unii Europejskiej korelacja między lukami produkcyjnymi otrzymanymi tymi metodami kształtowała się w granicach $0,8-0,9$ (European Commission, 2000). Warto przy tym zaznaczyć, że w ramach analiz cyklu koniunkturalnego stosowane są również inne metody, m.in. modele przełącznikowe Markowa, algorytm Bry-Boschan, dekompozycja Blancharda-Quaha oraz dekompozycja Beveridge'a-Nelsona. Modele przełącznikowe Markowa identyfikują zmiany faz cyklu, którymi steruje jednorodny łańcuch Markowa o zadanej liczbie reżimów stanów (por. Maciejowska, Zwiernik, 2005). Zastosowanie algorytmu Bry i Boschan (1971) umożliwia wskazanie okresu, w którym nastąpił zwrot cyklu, jeżeli zmiana dynamiki produktu utrzymuje się przez co najmniej dwa kwartały (por. Konopczak, 2009). W dekompozycji Beveridge'a-Nelsona zakłada się, że szoki oddziałujące na trend i komponent cykliczny są doskonale skorelowane, czyli zmiany trendu i cyklu są wywołane przez ten sam szok gospodarczy (por. McMorrow i Roger, 2001). Natomiast w dekompozycji Blancharda-Quaha przyjmuje się, że trend i komponent cykliczny są określane przez odmienne, niezależne czynniki (por. McCoy, 1997; McMorrow i Roger, 2001).

${ }^{38} \mathrm{~W}$ cenach stałych z 2000 r. Dane Eurostatu.

${ }^{39}$ Alternatywną metodą odsezonowywania szeregów czasowych jest metoda TRAMO/ SEATS. Metoda X-12-ARIMA ma relatywnie większe zastosowanie w przypadku krótkich szeregów czasowych i z tego względu została zastosowana w niniejszej pracy (więcej na temat porównania obydwu metod por. Hood, Ashley, Findley, 2000; Franses, Paap, 2005).

${ }^{40}$ Rezultaty otrzymane przy zastosowaniu obydwu testów wskazały, iż szereg PKB w Polsce jest zintegrowany w stopniu pierwszym I(1). W teście ADF liczba opóźnień została dobrana na podstawie minimalizacji kryterium Schwartza, natomiast w teście KPSS szerokość pasma została przyjęta na podstawie metody Neweya-Westa. 


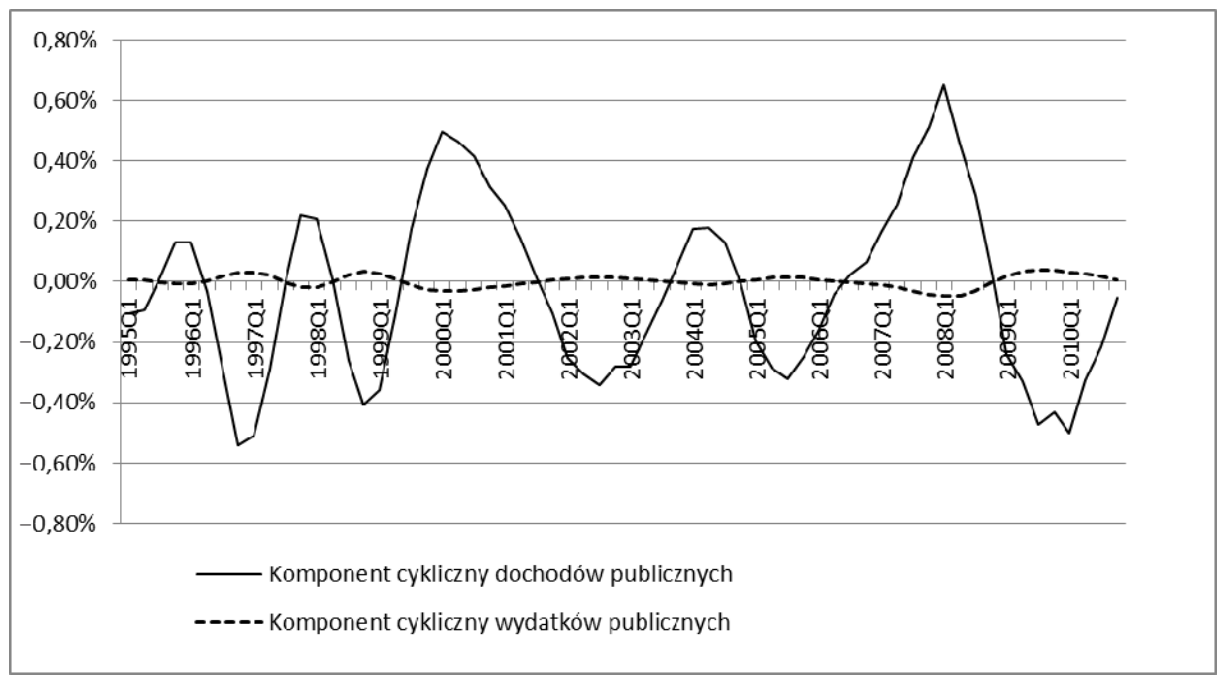

Rysunek 15. Komponenty cykliczne dochodów i wydatków publicznych w Polsce w latach 1995-2010 (w \% PKB)

Źródło: opracowanie własne na podstawie danych Eurostatu, GUS i Ministerstwa Finansów.

Jak wynika z rysunku 15, mimo wysokiej wartości bezwzględnej elastyczności wydatków związanych z bezrobociem względem PKB, komponent cykliczny wydatków publicznych w relacji do PKB jest nieznaczny, co wynika z niskiego udział wydatków wrażliwych na wahania koniunktury w wydatkach publicznych ogółem.

\subsection{Wpływ aktywnej polityki fiskalnej na przebieg fluktuacji gospodarczych w Polsce}

W wyniku skorygowania dochodów i wydatków publicznych o wyznaczone w poprzedniej części rozdziału komponenty cykliczne otrzymuje się komponenty strukturalne poszczególnych kategorii budżetowych. Wyznaczenie strukturalnych dochodów i wydatków publicznych umożliwia z kolei oszacowanie oddziaływania aktywnej polityki fiskalnej na przebieg cyklu koniunkturalnego w Polsce. Przy badaniu wpływu aktywnej polityki fiskalnej na fluktuacje gospodarcze przyjmować można, że poziom produkcji jest w krótkim okresie rosnącą funkcją deficytu budżetowego (por. Buti, Giudice, 2002) lub osobno badać wpływ poszczególnych kategorii budżetowych na kształtowanie się PKB (por. np. Baxter i King, 1993; Brunila, Buti i in't Veld, 2002; Ratto, Roeger i in't Veld, 2008; Brusselen, 2010). Jak wynika $\mathrm{z}$ analiz przeprowadzonych w poprzednich rozdziałach wydatki rządowe 
i niezryczałtowane podatki oddziałują w odmienny sposób na fluktuacje PKB. Z tego względu oddzielnie zbadano wpływ wydatków rządowych oraz niezryczałtowanych podatków na przebieg cyklu koniunkturalnego w Polsce. Do niezryczałtowanych podatków zaliczono PIT, CIT, podatki pośrednie oraz dochody funduszy celowych ze składek. Dochody publiczne z tych podatków i składek skorygowano o komponenty cykliczne, zgodnie z obliczeniami przedstawionymi we wcześniejszej części rozdziału, uzyskując strukturalne dochody z podatków niezryczałtowanych ${ }^{41}$.

Aktywną politykę fiskalną dotyczącą kształtowania wydatków rządowych zdefiniowano jako odchylenia strukturalnych wydatków rządowych w relacji do PKB od ich średniego poziomu w relacji do PKB w analizowanym okresie, czyli w latach 1995-2010 ${ }^{42}$. Analogicznie, aktywną politykę podatkową zdefiniowano jako odchylenia poziomu komponentów strukturalnych niezryczałtowanych podatków w relacji do PKB od ich średniego poziomu w relacji do PKB w analizowanym okresie. Miary dotyczące aktywnej polityki fiskalnej przedstawione zostały na rysunku 16.

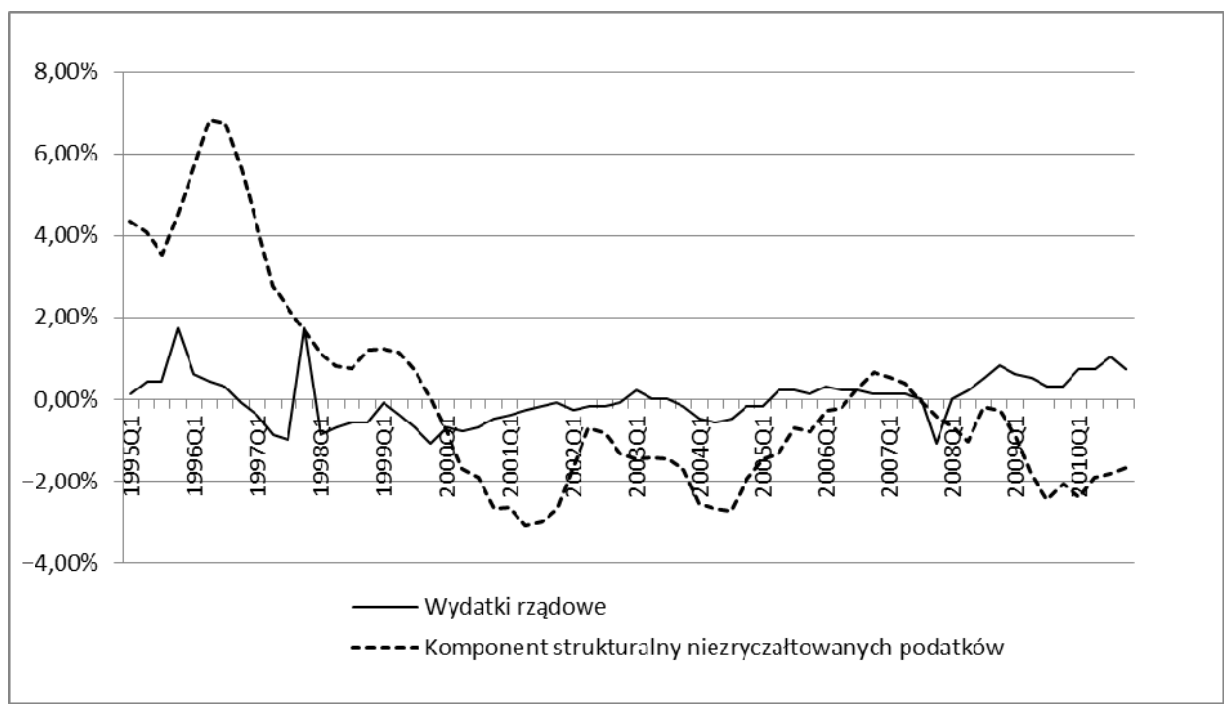

Rysunek 16. Odchylenia wydatków rządowych oraz strukturalnych dochodów z podatków niezryczałtowanych w relacji do PKB od średnich poziomów tych zmiennych w relacji do PKB w latach 1995-2010

Źródło: opracowanie własne na podstawie danych Eurostatu, GUS i Ministerstwa Finansów.

${ }^{41}$ Dokładniej rzecz ujmując otrzymana kategoria budżetowa, skrótowo określana w dalszej części rozdziału jako „strukturalne dochody z podatków niezryczałtowanych” lub „strukturalne dochody podatkowe”, stanowi „komponent strukturalny dochodów publicznych z niezryczałtowanych podatków i składek".

${ }^{42}$ Wydatki rządowe równają się strukturalnym wydatkom rządowym, ponieważ komponent cykliczny wydatków publicznych dotyczy jedynie wydatków na zasiłki dla bezrobotnych. 
W latach 1995-2010 wydatki rządowe ulegały znacznie mniejszym wahaniom niż strukturalne dochody z podatków niezryczałtowanych ${ }^{43}$. Można ponadto zaobserwować, że w latach 1996-2000 nastąpiło znaczne obniżenie się strukturalnego poziomu podatków. Obniżenie to miało charakter trwały. Jak ukazują m.in. Baxter i King (1993) oraz Bukowski i in. (2005) przejściowe zmiany w polityce fiskalnej oddziałują w inny sposób niż zmiany trwałe, zatem oszacowanie skutków trwałego obniżenia sią udziału strukturalnych dochodów podatkowych w PKB na podstawie mnożników wyznaczonych dla przejściowych zmian w polityce fiskalnej mogłoby być obarczone dużym błędem. Z tego względu w dalszej części analizę oddziaływania aktywnej polityki fiskalnej na przebieg fluktuacji gospodarczych w Polsce zawężono do lat 2001-2010. Jednocześnie analiza skutków trwałego obniżenia się strukturalnych dochodów podatkowych w latach 1996-2000 stanowi interesujące pole do dalszych badań.

Zarówno w przypadku wydatków rządowych, jak i strukturalnych dochodów z podatków niezryczałtowanych, wpływ aktywnej polityki fiskalnej na przebieg cyklu koniunkturalnego w Polsce zbadano na gruncie:

- podażowego modelu RBC, przedstawionego w rozdziale trzecim,

- uwzględniającego występowanie sztywności nominalnych modelu nowokeynesistowskiego, omówionego w rozdziale czwartym.

Oszacowania dotyczące wpływu zmian wydatków rządowych na kształtowanie się PKB w gospodarce polskiej zostały przedstawione na rysunku $17^{44}$.

$\mathrm{Z}$ przedstawionych oszacowań wynika, że wydatki rządowe poprzez efekty podażowe jedynie $\mathrm{w}$ niewielkim stopniu oddziaływały na kształtowanie się produkcji. Natomiast uwzględniając efekty popytowe, na gruncie modelu Smetsa i Woutersa (2003), otrzymuje się, że aktywna polityka fiskalna w zakresie wydatków rządowych wywierała relatywnie silniejszy wpływ na wahania koniunktury. W szczególności na podstawie modelu nowokeynesistowskiego uzyskano, że na skutek zwiększenia wydatków rządowych poziom PKB w latach 2009-2010 uległ podwyższeniu średnio o ok. $0,3 \%$. Zatem ekspansywna polityka fiskalna dotycząca wydatków rządowych w pewnym stopniu przyczyniła się do relatywnie dobrej sytuacji gospodarczej w Polsce w okresie kryzysu gospodarczego na świecie ${ }^{45}$.

${ }^{43}$ Warto w tym kontekście przytoczyć opracowanie Siwińskiej-Gorzelak (2010), z którego wynika, że duże wahania wydatków rządowych niekorzystnie wpływają na długofalowy wzrost gospodarczy.

${ }^{44} \mathrm{~W}$ przypadku analizy oddziaływania podażowego założono, że wydatki rządowe oddziałują na gospodarkę polską zgodnie $\mathrm{z}$ funkcjami reakcji na impuls przedstawionymi na rys. 1 . Natomiast wpływ wydatków rządowych przy uwzględnieniu oddziaływania popytowego oszacowano na podstawie funkcji reakcji na impuls zamieszczonych na rys. 7.

${ }^{45}$ Natomiast badania Aizenmana i Pasrichy (2011) wskazują, że w okresie kryzysu wydatki rządowe w Polsce miały charakter procykliczny i negatywnie wpłynęły na kształtowanie się PKB. Różnice w otrzymanych rezultatach mogą wynikać z odmiennego okresu objętego badaniem. Szereg czasowy badany przez tych autorów jest bowiem krótszy i kończy się na I kwartale 2010 roku. Jednocześnie warto zaznaczyć, że według Aizenmana i Pasrichy w pozostałych gospodarkach 


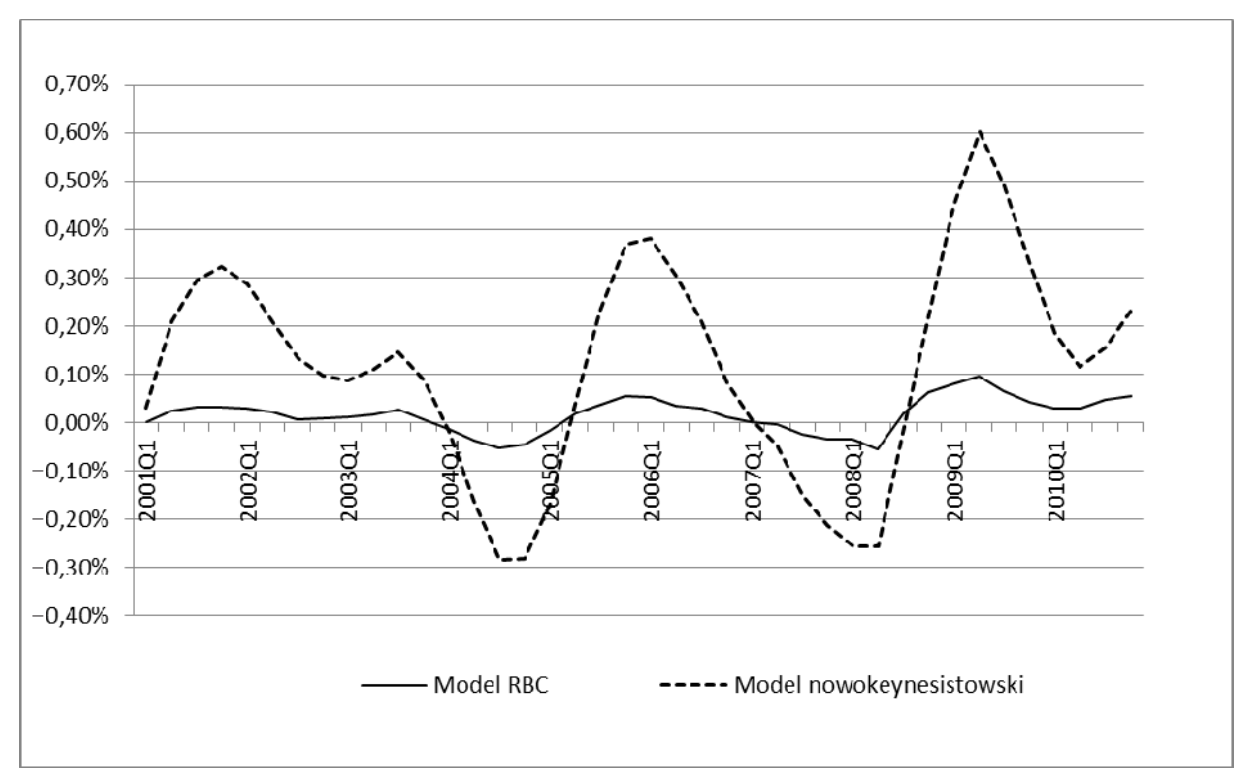

Rysunek 17. Wpływ aktywnej polityki fiskalnej w zakresie wydatków rządowych na kształtowanie się PKB w Polsce w latach 2001-2010 na gruncie modelu RBC oraz modelu nowokeynesistowskiego (procentowe odchylenia PKB od poziomu bazowego, $\mathrm{tj}$. bez prowadzenia aktywnej polityki fiskalnej)

Źródło: opracowanie własne na podstawie danych Eurostatu, GUS i Ministerstwa Finansów.

Analogicznie, na podstawie funkcji reakcji przedstawionych $\mathrm{w}$ rozdziale trzecim oraz $\mathrm{w}$ rozdziale czwartym, poddano analizie wpływ zmian strukturalnych dochodów podatkowych na kształtowanie się PKB w latach 2001-201046.

Z przeprowadzonych oszacowań ukazanych na rysunku 18 wynika, że aktywna polityka fiskalna po stronie dochodowej w większym stopniu oddziaływała na zmiany PKB w latach 2001-2010 niż zmiany wydatków rządowych. Wynika to $\mathrm{z}$ jednej strony $\mathrm{z}$ wyższego, co do wartości bezwzględnej, wartości mnożnika, a z drugiej strony $\mathrm{z}$ większych, niż w przypadku wydatków rządowych, fluktuacji strukturalnych dochodów podatkowych. Analiza otrzymanych wyników wskazuje również, że uwzględnienie sztywności nominalnych, odmiennie niż w przypadku wydatków rządowych, nie wpływa na siłę oddziaływania podatków niezryczałtowanych na gospodarkę.

wschodzących objętych badaniem w okresie kryzysu prowadzono antycykliczną politykę fiskalną (por. Wojtyna, 2012).

${ }^{46}$ Analiza oddziaływania podażowego opiera się na funkcji reakcji na impuls ukazanej na rysunku 3. Oszacowania dotyczące oddziaływania podatków w warunkach występowania sztywności nominalnych opierają się natomiast na funkcjach reakcji przedstawionych na rysl. 11. 


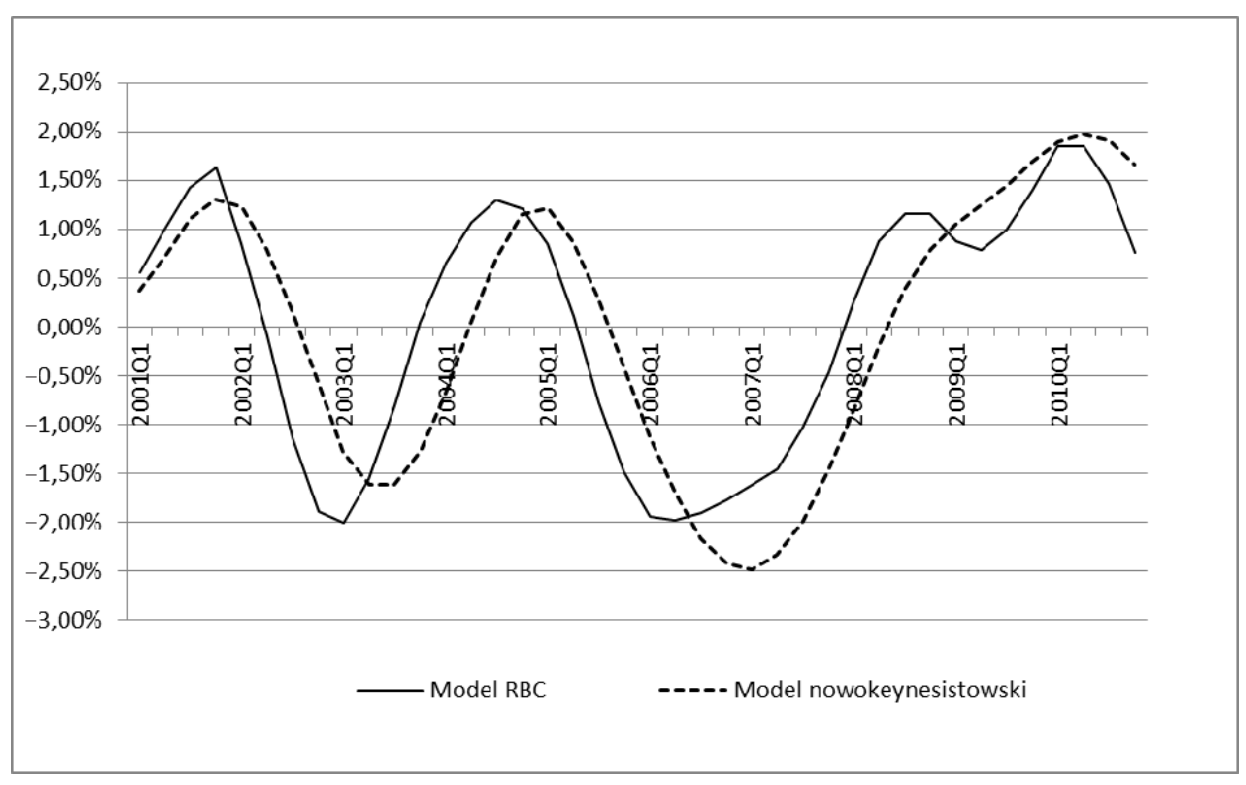

Rysunek 18. Wpływ aktywnej polityki fiskalnej dotyczącej podatków niezryczałtowanych na kształtowanie się PKB w Polsce w latach 2001-2010 na gruncie modelu RBC oraz modelu nowokeynesistowskiego (procentowe odchylenia PKB od poziomu bazowego, tj. bez prowadzenia aktywnej polityki fiskalnej)

Źródło: Opracowanie własne na podstawie danych Eurostatu, GUS i Ministerstwa Finansów.

Porównując wyniki otrzymane na gruncie modelu RBC i modelu nowokeynesistowskiego można ponadto zauważyć, że w warunkach występowania sztywności nominalnych oddziaływanie podatków na PKB jest przesunięte w czasie. Wynika to z tego, że gdy ceny są doskonale elastyczne, wówczas zmiany opodatkowania oddziałują na decyzje podmiotów mikroekonomicznych szybciej, ale jednocześnie po ustaniu szoku gospodarka prawie natychmiastowo powraca do stanu sprzed pojawienia się zaburzenia. Natomiast jeśli ceny dostosowują się stopniowo, wówczas efekty zmian opodatkowania są co prawda wolniejsze, ale jednocześnie bardziej długotrwałe.

Otrzymane wyniki wskazują, że zmniejszenie strukturalnych dochodów podatkowych, które miało miejsce począwszy od $2007 \mathrm{roku}^{47}$, wpłynęło na podwyższenie PKB w latach $2009-2010$ o ponad $1 \%{ }^{48}$. Zatem aktywna polityka podatkowa oddziaływała w o wiele większym stopniu na złagodzenie w Polsce skutków kryzysu na świecie, niż polityka fiskalna po stronie wydatkowej.

${ }^{47}$ Obejmujące zarówno obniżkę podatku PIT, jak i składek na ubezpieczenie społeczne.

${ }^{48}$ Zgodnie z symulacjami wykonanymi na podstawie modelu RBC - o 1,2\%, natomiast według oszacowań wykonanych w oparciu o model nowokeynesistowski - o 1,6\%. 
Badania empiryczne wskazują, że wbrew postulatom normatywnym reakcje polityki fiskalnej na wahania koniunktury mają często charakter procykliczny (por. Gavin i in., 1996; Calderón, Schmidt-Hebbel, 2003; Lane, 2003; Talvi i Vegh, 2005; Bogdanov, 2010). Przyczyn procykliczności aktywnej polityki fiskalnej upatruje się m.in. w ograniczeniach płynności wynikających z poziomu deficytu (Perry, 2003; Woo, 2005) oraz słabościach instytucjonalnych (Kaufmann, Kraay i Mastruzzi, 2004; Woo, 2005; Alesina i Tabellini, 2008) ${ }^{49}$. W celu zbadania, czy polityka fiskalna w Polsce w latach 2001-2010 miała charakter pro- czy antycykliczny porównano kształtowanie się rzeczywistej luki produktowej, wyznaczonej na podstawie filtra $\mathrm{CF}$, z hipotetyczną luką produktową, która miałaby miejsce w przypadku braku prowadzenia aktywnej polityki fiskalnej ${ }^{50}$. Porównanie tych luk produktowych ukazano na rysunku 19.

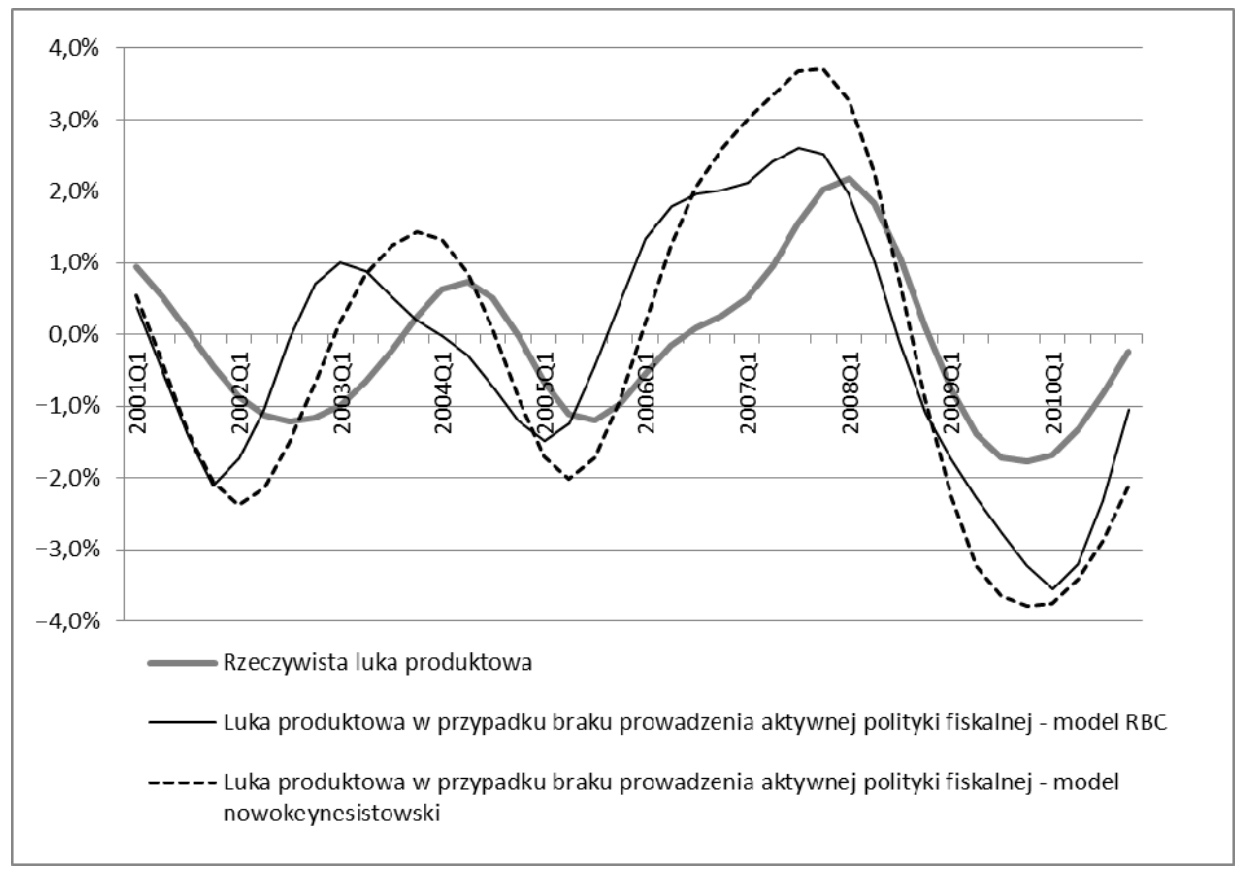

Rysunek 19. Luka produktowa w gospodarce polskiej w latach 2001-2010 w przypadku braku prowadzenia aktywnej polityki fiskalnej (w \%)

Źródło: Opracowanie własne na podstawie danych Eurostatu, GUS i Ministerstwa Finansów.

${ }^{49}$ Szerzej na temat możliwych przyczyn procykliczności polityki fiskalnej por. np. Działo (2012).

${ }^{50}$ Luka produktowa w przypadku braku prowadzenia aktywnej polityki fiskalnej wyznaczona została poprzez skorygowanie rzeczywistej luki produktowej o wpływ aktywnej polityki fiskalnej, który przedstawiono na rys. 17 oraz 18 . Termin „,rzeczywista luka produktowa” oznacza, że jest ona wyznaczona na podstawie rzeczywistego PKB, przy czym jest to oczywiście zmienna nieobserwowalna, której wartość uzależniona jest od zastosowanej metody filtracji. 
Analizując dane przedstawione na rysunku 19 można zaobserwować, że w przypadku braku prowadzenia aktywnej polityki fiskalnej wahania koniunktury w latach 2001-2010 cechowałyby się znacznie większą amplitudą. Przeprowadzone oszacowania wskazują, że w wyniku aktywnej polityki fiskalnej odchylenie standardowe luki produktowej w analizowanym okresie uległo zmniejszeniu o ok. 40-50\% ${ }^{51}$. Również oszacowania Mackiewicza (2010) wskazują, że polityka fiskalna w Polsce ma charakter antycykliczny ${ }^{52}$.

W szczególności z przeprowadzonych oszacowań wynika, że aktywna polityka fiskalna przyczyniła się w znacznym stopniu do zmniejszenia, co do wartości bezwzględnej, ujemnej luki produktowej po pojawieniu się kryzysu finansowego na rynkach światowych. Na podstawie modelu RBC otrzymuje się, że prowadzenie aktywnej polityki fiskalne wpłynęło na ograniczenie średniej wartości luki produktowej w latach 2009-2010 o ponad połowę, tj. z -2,5\%. do $-1,2 \%$. Obliczenia wykonane na podstawie modelu nowokeynesistowskiego wskazują na nawet silniejsze oddziaływanie aktywnej polityki fiskalnej na złagodzenie skutków kryzysu. Według oszacowań uwzględniających efekty popytowe na skutek poluzowania polityki fiskalnej w latach 2009-2010 średnia wartość luki produktowej uległa ograniczeniu z $-3,3 \%$. do $-1,2 \%$, czyli o ponad $60 \%{ }^{53}$.

Antycykliczny charakter polityki fiskalnej w Polsce nie stanowi wyjątku w Unii Europejskiej. Również w większości krajów Unii Gospodarczej i Walutowej polityka fiskalna ma charakter antycykliczny, w okresie spowolnienia wzrostu gospodarczego następowało zazwyczaj zwiększenie strukturalnego deficytu pierwotnego sektora finansów publicznych (por. European Commission, $2008,2011)^{54}$.

\footnotetext{
${ }^{51} \mathrm{~W}$ przypadku modelu RBC otrzymuje się, że na skutek aktywnej polityki fiskalnej odchylenie standardowe luki produktowej uległo zmniejszeniu z 1,7\% do $1,0 \%$, czyli o $39,0 \%$. Natomiast z modelu nowokeynesistowskiego wynika, że na skutek aktywnej polityki fiskalnej odchylenie standardowe luki produktowej uległo zmniejszeniu z 2,2\% na 1,0\%, czyli o 52,9\%.

${ }^{52}$ Od 1999 r. Wcześniej, zgodnie z oszacowaniami Mackiewicza (2010), polityka fiskalna w Polsce miała charakter acykliczny. Natomiast według Coricelliego (2004), w krajach Europy Środowo-Wschodniej, w tym w Polsce, polityka fiskalna przed wstąpieniem do Unii Europejskiej miała charakter procykliczny (por. też Jędrzejowicz, Kitala i Wronka, 2008).

${ }^{53}$ Warto w tym kontekście zaznaczyć, że jak wskazuje Wojtyna (2010), analizując kraje na średnim poziomie rozwoju, do których zalicza m.in. Polskę, w czasie ostatniego kryzysu ze względu na relatywnie dobrą sytuację budżetową kraje na średnim poziomie rozwoju mogły prowadzić antycykliczną politykę fiskalną bez wzrostu premii za ryzyko.

${ }^{54}$ Jak wynika z badań Galiego i Perottiego (2003) oraz Wyplosza (2006) powstanie Unii Gospodarczej i Walutowej zwiększyło stopień antycykliczności polityki fiskalnej w krajach tworzących strefę euro. Z drugiej strony, do całkowicie odmiennych wniosków doszli Golinelli i Momigliano (2008) (nt. procykliczności polityki fiskalnej w okresie tworzenia strefy euro por. też Gajewski, 2011).
} 


\subsection{Skuteczność automatycznych stabilizatorów i metody jej zwiększenia}

Wpływ automatycznych stabilizatorów koniunktury na wygładzenie wahań PKB mierzony jest na różne sposoby. Ich skuteczność rozpatrywać można porównując rzeczywiste wahania koniunktury z fluktuacjami, które miałyby miejsce, gdyby nie występowały cykliczne podatki i wydatki publiczne, czyli wysokość dochodów i wydatków publicznych nie była wrażliwa na wahania koniunktury. Z drugiej strony efektywność automatycznych stabilizatorów analizować można, porównując rzeczywiste wahania koniunktury z fluktuacjami gospodarczymi występującymi, gdy wpływ cyklicznych komponentów dochodów i wydatków publicznych na saldo budżetu jest neutralizowany przez dyskrecjonalne zmiany w polityce fiskalnej mające na celu utrzymanie deficytu finansów publicznych na niezmienionym poziomie. Pierwsza z opisanych metod przedstawiona jest w opracowaniu Komisji Europejskiej (European Commission, 2001), natomiast druga - m.in. w pracy Brunili, Butiego, in't Velda (2002). W niniejszym rozdziale zastosowano drugą z tych metod ${ }^{55}$.

Im większe wahania PKB w przypadku utrzymywania niezmienionego poziomu dochodów i wydatków publicznych, tym większe znacznie dla wygładzenia wahań koniunktury ma umożliwienie działania automatycznych stabilizatorów koniunktury, tj. nie niwelowanie deficytu cyklicznego przez aktywną politykę fiskalną. W rezultacie skuteczność automatycznych stabilizatorów koniunktury jest uzależniona od wielkości komponentów cyklicznych dochodów i wydatków publicznych oraz od siły oddziaływania na PKB zmian w wydatkach rządowych, mających na celu utrzymanie stałej wysokości deficytu sektora finansów publicznych.

Analogicznie jak w przypadku analizy aktywnej polityki fiskalnej, wpływ automatycznych stabilizatorów koniunktury zbadano zarówno na gruncie modelu $\mathrm{RBC}$, jak i modelu nowokeynesistowskiego. W ramach analizy podażowej przyjęto, że wydatki rządowe oddziałują na gospodarkę zgodnie z funkcjami reakcji na impuls ukazanymi na rysunku 1. Analiza uwzględniająca występowanie sztywności nominalnych opiera się natomiast na funkcjach reakcji na impuls przedstawionych na rysunku 7. Oszacowania dotyczące wysokości luki produktowej w przypadku niwelowania działania automatycznych stabilizatorów koniunktury, uzyskane na podstawie wymienionych funkcji reakcji na impuls oraz przedstawionych we

${ }^{55}$ Wybór metody przedstawionej przez Brunilę, Butiego, in’t Velda (2002) podyktowany jest faktem, że metoda ta ma większe znaczenie aplikacyjne z punktu widzenia oceny możliwych skutków prowadzenia różnych wariantów polityki fiskalnej. Stosowanie tej metody umożliwia bowiem porównanie efektów swobodnego działania automatycznych stabilizatorów koniunktury ze skutkami wyeliminowania ich działania poprzez zmiany dochodów i wydatków strukturalnych, w celu utrzymania stałego poziomu całkowitego deficytu. Natomiast oszacowanie skutków wyeliminowania wbudowanej reakcji podatków na wahania koniunktury ma mniejsze znaczenie aplikacyjne, ponieważ zastąpienie rzeczywiście występujących podatków podatkami zryczałtowanymi, czyli podatkami typu lump sum, nie jest praktycznie możliwe. 
wcześniejszej części rozdziału oszacowań dotyczących komponentów cyklicznych podatku PIT, składek na ubezpieczenia społeczne, CIT, podatków pośrednich oraz wydatków związanych z bezrobociem przedstawiono na rysunku 20.

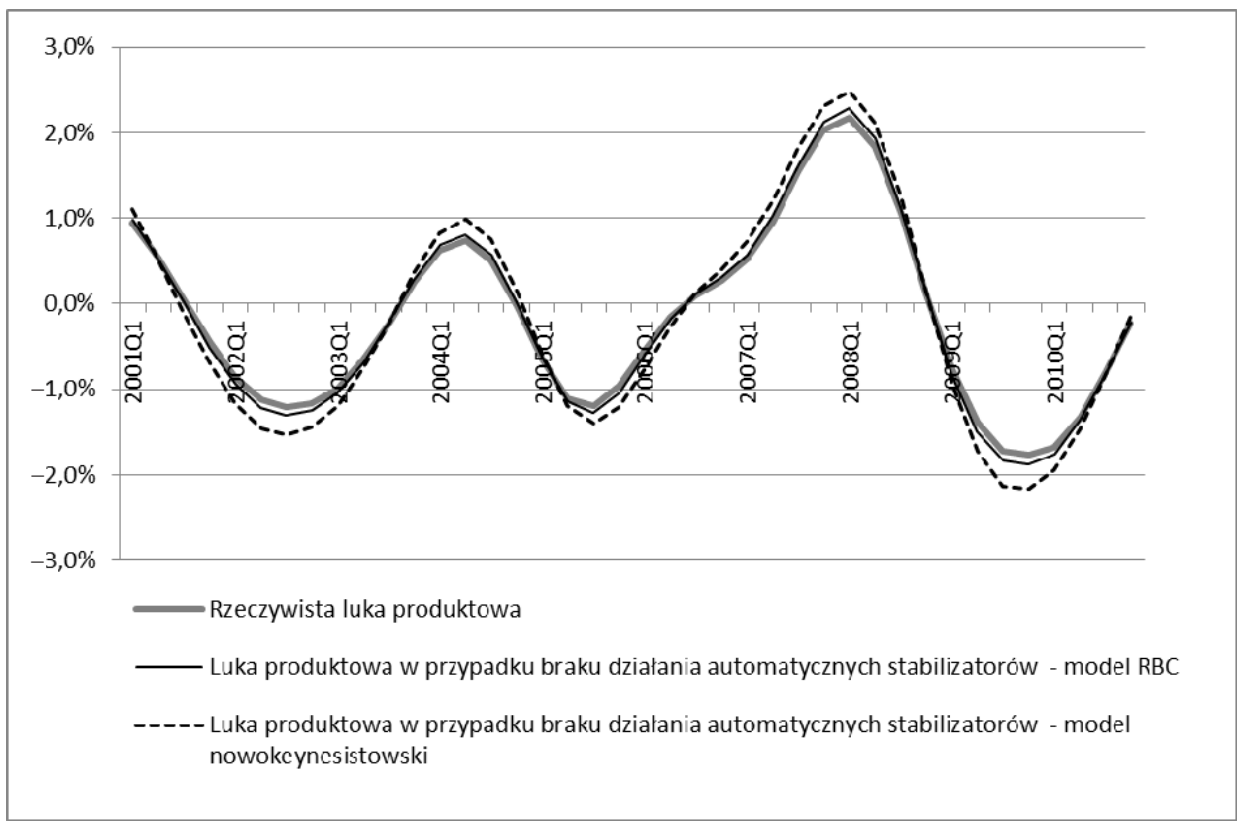

Rysunek 20. Luka produktowa w gospodarce polskiej w latach 2001-2010 w przypadku braku działania automatycznych stabilizatorów koniunktury (w \%).

Źródło: opracowanie własne na podstawie danych Eurostatu, GUS i Ministerstwa Finansów.

Z przeprowadzonych oszacowań wynika, że niwelowanie działania automatycznych stabilizatorów poprzez zmiany w wydatkach rządowych znacznie słabiej oddziałuje na gospodarkę w przypadku modelu podażowego niż przy uwzględnieniu występowania sztywności nominalnych. Na gruncie modelu nowokeynesistowskiego uzyskuje się, że umożliwianie działania automatycznych stabilizatorów zmniejszyło odchylenie standardowe luki produktowej w analizowanym okresie o $16,3 \%$. Natomiast, zgodnie z oszacowaniami uwzględniającymi jedynie mechanizmy podażowe, swobodne działanie automatycznych stabilizatorów powoduje zmniejszenie odchylenia standardowego luki produktowej zaledwie o 5,6\%.

Automatyczne stabilizatory koniunktury nabiorą szczególnego znaczenia po wstąpieniu Polski do strefy euro, ponieważ w strefie euro polityka pieniężna nie będzie mogła pełnić roli instrumentu przeciwdziałającego skutkom szoków asymetrycznych. Według stosowanego przez OECD modelu INTERLINK automatyczne stabilizatory koniunktury w krajach należących do strefy euro wygładzają lukę pro- 
dukcyjną średnio o 23\% (European Commission, 2001) ${ }^{56}$. Nowsze oszacowania, które dla krajów Unii Europejskiej przeprowadzili Dolls, Fuest i Peichl (2009) wskazują z kolei, że automatyczne stabilizatory koniunktury zmniejszają fluktuacje gospodarcze aż o $36 \%^{57}$. Porównując przedstawione wyniki z oszacowaniami uzyskanymi w niniejszym rozdziale na podstawie zarówno modelu $\mathrm{RBC}$, jak i modelu nowokeynesistowskiego, zaobserwować można, że siła działania automatycznych stabilizatorów koniunktury w Polsce jest relatywnie niewielka ${ }^{58}$.

Na łączną skuteczność automatycznych stabilizatorów w Polsce w różnym stopniu oddziałują poszczególne kategorie budżetowe. Przyjmując za jeden z celów polityki makroekonomicznej zminimalizowanie amplitudy wahań koniunktury, wskazane jest zwiększenie roli tych kategorii budżetowych, które silnie działają jako automatyczny stabilizator. W tabeli 12 , na podstawie wykonanych wcześniej obliczeń dotyczących elastyczności względem PKB podatku PIT, CIT, podatków pośrednich, składek na fundusze celowe oraz zasiłków dla bezrobotnych, pokazane zostało, jak zwiększenie poszczególnych kategorii budżetowych o $1 \%$ PKB wpłynęłoby na zmniejszenie amplitudy fluktuacji gospodarczych w Polsce. Przedstawione oszacowania opierają się również na funkcjach reakcji na impuls, wyznaczonych w trzecim i czwartym rozdziale pracy.

Tabela 12. Wpływ zwiększenia poszczególnych dochodów i wydatków publicznych o 1\% PKB na procentowe zmniejszenie odchylenia standardowego luki produktowej w latach 2001-2010

\begin{tabular}{|l|c|c|}
\hline \multicolumn{1}{|c|}{ Kategoria budżetowa } & $\begin{array}{c}\text { Model } \\
\text { RBC }\end{array}$ & $\begin{array}{c}\text { Model } \\
\text { nowokeynesistowski }\end{array}$ \\
\hline Podatek dochodowy od osób fizycznych & 0,15 & 0,85 \\
\hline Składki na fundusze celowe & 0,12 & 0,67 \\
\hline Podatek dochodowy od osób prawnych & 0,16 & 0,88 \\
\hline Podatki pośrednie & 0,07 & 0,42 \\
\hline Pasywne formy przeciwdziałania bezrobociu & 0,28 & 1,63 \\
\hline
\end{tabular}

Źródło: opracowanie własne na podstawie danych Eurostatu, GUS i Ministerstwa Finansów.

${ }^{56}$ Zestawienie wyników badań dotyczących skuteczności automatycznych stabilizatorów koniunktury w wybranych krajach Unii Europejskiej zawarte jest w Scharnagl, Todter (2004). Skuteczność automatycznych stabilizatorów koniunktury może być przy tym uzależniona od charakteru danego szoku gospodarczego, tj. od tego czy dotyczy on konsumpcji, inwestycji, eksportu, czy produktywności. Największy wpływ na kształtowanie się cyklicznego komponentu deficytu budżetowego, co przekłada się na wysoką skuteczność automatycznych stabilizatorów koniunktury, ma szok wpływający na wysokość konsumpcji, natomiast najniższy wpływ - szok dotyczący produktywności (Brunila, Buti i in’t Veld, 2002).

${ }^{57}$ Jak wskazują Dolls, Fuest i Peichl (2009) siła działania automatycznych stabilizatorów koniunktury w Europie jest przy tym wyższa niż w gospodarce amerykańskiej.

${ }^{58} \mathrm{Z}$ drugiej strony warto przytoczyć również wyniki uzyskane dla krajów strefy euro na podstawie modelu NiGEM, zgodnie z którymi automatyczne stabilizatory wygładzają wahania koniunktury jedynie o 11\% (Barrell, Pina, 2002). 
Podobnie jak poprzednio otrzymano, że występowanie sztywności nominalnych w gospodarce znacznie zwiększa siłę działania automatycznych stabilizatorów koniunktury. Różnice pomiędzy oszacowaniami dla poszczególnych kategorii budżetowych wynikają natomiast $\mathrm{z}$ odmiennej wrażliwości na fluktuacje gospodarcze różnych rodzajów podatków i wydatków związanych z bezrobociem.

$\mathrm{Z}$ danych zamieszczonych $\mathrm{w}$ tabeli 12 wynika, że na zmniejszenie wahań PKB najsilniej wpłynęłoby zwiększenie wydatków na pasywne formy przeciwdziałania bezrobociu. $Z$ drugiej jednak strony wzrost tego typu wydatków może przyczynić się do wzrostu bezrobocia i ograniczenia PKB. Wyższe zasiłki dla bezrobotnych mogą bowiem zniechęcać gospodarstwa domowe do podjęcia pracy, ograniczając podaż pracy ${ }^{59}$. Z reguły szczególnie wysoki stosunek zasiłków uzyskiwanych w przypadku zrezygnowania z pracy do płacy netto, a więc i negatywne oddziaływanie zasiłków na podaż pracy, występuje w przypadku, gdy drugi z małżonków jest bezrobotny (por. van den Noord, Heady, 2002). Ponadto wyższe wydatki na pasywne formy przeciwdziałania bezrobociu negatywnie oddziałują na oszczędności, ponieważ z jednej strony zmniejszają obecny dochód, a z drugiej strony zmniejszają niepewność co do przyszłych dochodów (por. Leibfritz, Thornton, Bibbee, 1997; van den Noord, Heady, 2002).

Porównując podatki dochodowe i pośrednie, zaobserwować można, że podatki dochodowe działają silniej jako automatyczne stabilizatory koniunktury. Z tego względu, z punktu widzenia zwiększenia skuteczności antycyklicznej polityki fiskalnej, wskazane byłoby przesunięcie obciążeń podatkowych od podatków pośrednich w stronę podatków bezpośrednich. Zarazem jednak zniekształcający wpływ podatków dochodowych jest silniejszy niż w przypadku podatków konsumpcyjnych, ponieważ podatki dochodowe oprócz wpływu na konsumpcję ograniczają także oszczędności i inwestycje (por. Tanzi i Zee, 1998 i 2000; Arnold, 2008 oraz Myles, 2009). Jak wspomniano w rozdziale pierwszym negatywne oddziaływanie podatków dochodowych na kształtowanie się oszczędności odbywa się poprzez zmniejszenie przychodu z oszczędności oraz zmniejszenie dochodu do dyspozycji w wieku produkcyjnym, czyli okresie, w którym generowane są oszczędności. Wysokość opodatkowania, oprócz oddziaływania na poziom oszczędności, może również wpływać bezpośrednio na opłacalność inwestycji. Przy wyższym podatku CIT wyższa musi być stopa zwrotu przed opodatkowaniem z dodatkowej inwestycji, by otrzymać określoną wysokość stopy zwrotu po opodatkowaniu ${ }^{60}$. Ponadto wzrost podatków dochodowych nakładanych na dochody

${ }^{59}$ Dodatnią zależność między wysokością niezryczałtowanych transferów socjalnych a stopą bezrobocia potwierdzają m.in. doświadczenia Hiszpanii i Irlandii (por. Góra, 2005). Z drugiej strony, w świetle dominującej krytyki zasadności stosowania zasiłków dla bezrobotnych, warty przytoczenia jest też pogląd Acocelli (2002), że zasiłki dla bezrobotnych są czynnikiem zwiększającym elastyczność rynku pracy, ponieważ dzięki zasiłkom przedsiębiorcy podczas zwolnień napotykają mniejszy sprzeciw ze strony pracowników.

${ }^{60} \mathrm{~W}$ przypadku podatku CIT szczególnie istotny jest przy tym element konkurencji między krajami (por. np. Owsiak, 2012). Warto przy okazji zaznaczyć, że na opłacalność inwestycji wpływa 
z pracy, powoduje, że relacja płacy uzyskiwanej przez pracownika do kosztów pracy ponoszonych przez pracodawcę ulega zwiększeniu. Zatem z jednej strony podatki dochodowe stanowią skuteczniejsze niż podatki pośrednie narzędzie łagodzenia wahań koniunktury ${ }^{61} . \mathrm{Z}$ drugiej jednak strony podatki dochodowe silniej niż podatki pośrednie negatywnie oddziałują na wzrost gospodarczy w dłuższym okresie, poprzez zniekształcający wpływ na decyzje dotyczące oszczędności i inwestycji, a także popyt na pracę i podaż pracy ${ }^{62}$.

Wyższą skuteczność antycyklicznej polityki fiskalnej można uzyskać nie tylko poprzez podniesienia podatków dochodowych, ale także w wyniku zwiększenia progresji podatkowej w PIT. Jednak, mimo że często wskazuje się progresję podatkową jako główny mechanizm automatycznej stabilizacji koniunktury, to jej wpływ na antycykliczne działanie pasywnej polityki fiskalnej w Polsce jest relatywnie niewielki. Przykładowo, zniesienie trzeciej stawki podatkowej od 2009 roku wpłynęło na ograniczenie skuteczności PIT jako automatycznego stabilizatora koniunktury jedynie o ok. 8\%. Zarazem zwiększenie progresji może negatywnie oddziaływać na poziom oszczędności. W przypadku zwiększenia progresywności podatku PIT następuje bowiem relatywne zmniejszenie się dochodów osób zamożniejszych, które cechują się z reguły wyższą krańcową skłonnością do oszczędzania niż osoby mniej zarabiające. Progresywne podatki oprócz wpływu na oszczędności, mogą także negatywnie oddziaływać na podaż pracy, ponieważ wiążą się z relatywnie wysokimi krańcowymi stopami podatkowymi. Progresja podatkowa zmniejsza ponadto stopę zwrotu z akumulacji kapitału ludzkiego utracona płaca podczas edukacji jest niżej opodatkowana niż wysoka płaca po zakończeniu okresu nauki ${ }^{3}$.

Jak wynika z powyższej analizy, zmiany w systemie podatkowym prowadzące do zwiększenia skuteczności działania automatycznych stabilizatorów

efektywne opodatkowanie inwestycji, które zazwyczaj uzależnione jest nie tylko od stawki podatku CIT, ale także od formy finansowania inwestycji. Finansowanie inwestycji z długu jest niżej opodatkowane niż finansowanie inwestycji ze środków własnych, natomiast finansowanie inwestycji nową emisją akcji jest z reguły wyżej opodatkowane niż finansowanie inwestycji z zysku (por. Leibfritz, Thornton, Bibbee, 1997).

${ }^{61}$ Dlatego, jak zaznacza Owsiak (2011b), preferowanie podatków pośrednich wpłynęło na zmniejszenie skuteczności automatycznych stabilizatorów.

${ }^{62}$ Porównując w szerszym kontekście skutki podatków dochodowych i pośrednich warto zarazem wspomnieć, że podatki dochodowe w większym stopniu umożliwiają redystrybucję dochodu.

${ }^{63}$ Jednocześnie występują również pozytywne mechanizmy oddziaływania zwiększenia progresji podatkowej na wzrost gospodarczy. Z powodu niedoskonałości rynku kredytowego osoby biedne nie mają dostępu do kredytu, co obniża im możliwość inwestycji w kapitał ludzki, nawet gdy stopa zwrotu z niego byłaby wysoka. Redystrybucja dochodu, zwiększając dochody osób mniej zamożnych, zwiększa również możliwość ich inwestowania w kapitał ludzki. Jak wskazują Leibfritz, Thornton i Bibbee (1997), zwiększenie progresji podatkowej może obniżać presję na wzrost płac i w rezultacie prowadzić do wzrostu popytu na pracę. Ponadto z analiz, które przeprowadzili Panek i Kliber (2007) wynika, że występowanie progresji podatkowej zwiększa dobrobyt społeczny. 
koniunktury, polegające na zwiększeniu roli podatków dochodowych lub progresji podatkowej, jednocześnie nie są wskazane z punktu widzenia zwiększania stymulacyjnej roli polityki fiskalnej, ze względu na potencjalny negatywny wpływ takich zmian na kształtowanie się zatrudnienia, oszczędności i inwestycji w gospodarce.

\section{Podsumowanie}

W rozdziale zbadano wpływ aktywnej i pasywnej polityki fiskalnej na przebieg cyklu koniunkturalnego w Polsce. Jak wskazuje Owsiak (2002) pasywna polityka fiskalna jest związana z występowaniem cyklicznego deficytu sektora finansów publicznych, będącego rezultatem fluktuacji gospodarczych i działającego jako automatyczny stabilizator koniunktury. Aktywna polityka fiskalna polega natomiast na kształtowaniu strukturalnych dochodów i wydatków publicznych. W pracy wykorzystano metodę wyodrębniania cyklicznych i strukturalnych komponentów budżetowych opartą na szacunkach luki produktowej oraz elastyczności dochodów i wydatków budżetowych względem PKB. Deficyt strukturalny wyznaczony tą metodą, przedstawioną m.in. w opracowaniu Fedelino, Ivanovy i Hortona (2009), nie zawiera przejściowych efektów polityki fiskalnej nie związanych z wahaniami koniunktury. Ponadto, w odróżnieniu od podejścia zaproponowanego przez Blancharda (1990), uwzględnia, że wahania koniunktury mogą wynikać z innych przyczyn niż fluktuacje stopy bezrobocia.

W zastosowanej metodzie dekompozycji komponentów budżetowych na część strukturalną i cykliczną otrzymane wyniki uzależnione są od zastosowanej metody wyznaczania luki produktowej oraz elastyczności dochodów i wydatków publicznych względem PKB. Lukę produktową oszacowano na podstawie filtra Christiano i Fitzgeralda (1999). Natomiast elastyczności dochodów i wydatków publicznych względem PKB obliczono w oparciu o metodą dwustopniową, wykorzystującą analizę systemu podatkowego. Jak wskazują Coricelli i Ercolani (2002) w metodzie tej w pierwszym kroku, na podstawie danych dotyczących systemu podatkowego, bada się zależność pomiędzy wpływami podatkowymi a bazą podatkową, a w drugim kroku wyznacza się równanie regresji między bazą podatkową, lub zmienną makroekonomiczną stanowiącą przybliżenie bazy podatkowej, a PKB. Do dochodów sektora finansów publicznych wrażliwych na wahania koniunktury, analogicznie jak w pracy Momigliano i Staderiniego (1999), zaliczono podatek dochodowy od osób fizycznych, podatek dochodowy od osób prawnych, dochody funduszy celowych ze składek oraz podatki pośrednie. Założono ponadto, podobnie jak m.in. van den Noord (2000), że jedynymi wydatkami publicznymi bezpośrednio uzależnionymi od fluktuacji gospodarczych są wydatki na pasywne formy przeciwdziałania bezrobociu. Otrzymano, że wśród dochodów 
publicznych najniższą elastycznością względem PKB, wynoszącą 0,573 , cechują się wpływy z podatków pośrednich. W przypadku PIT, CIT oraz składek oszacowania elastyczności nie różnią się w sposób statystycznie istotny od jedności. Natomiast znacznie wyższą od jedności (w ujęciu bezwzględnym) elastyczność względem PKB uzyskano dla wydatków na pasywne formy przeciwdziałania bezrobociu.

Na podstawie kształtowania się strukturalnych, tj. skorygowanych o komponenty cykliczne, wpływów podatkowych oraz wydatków rządowych zbadano, w jaki sposób aktywna polityka fiskalna oddziaływała na przebieg cyklu koniunkturalnego w Polsce. Zaobserwowano, że aktywna polityka fiskalna po stronie dochodowej w większym stopniu wpływała na zmiany PKB niż zmiany wydatków rządowych. Wynika to z jednej strony z wyższego, co do wartości bezwzględnej, wartości mnożnika, a z drugiej strony z większych, niż w przypadku wydatków rządowych, fluktuacji strukturalnych dochodów podatkowych.

Zmiany wydatków rządowych, poprzez efekty podażowe, jedynie w niewielkim stopniu oddziaływały na sytuację gospodarczą w Polsce. Natomiast uwzględniając popytowe efekty wydatków rządowych, na gruncie modelu Smetsa i Woutersa (2003), otrzymuje się, że aktywna polityka fiskalna w zakresie wydatków rządowych wywierała relatywnie silniejszy wpływ na wahania koniunktury. W szczególności na podstawie modelu nowokeynesistowskiego uzyskano, że zwiększenie wydatków rządowych podwyższyło poziom PKB w Polsce w latach 2009-2010 średnio o ok. 0,3\%, łagodząc negatywne skutki oddziaływania kryzysu finansowego na świecie.

Z wykonanych oszacowań wynika również, że zmniejszenie strukturalnych dochodów podatkowych, które miało miejsce począwszy od 2007 roku, przełożyło się na podwyższenie poziomu PKB w latach 2009-2010 o ponad 1\%. W rezultacie zmiany podatkowe przyczyniły się, $\mathrm{w}$ większym stopniu niż zmiany wydatków rządowych, do relatywnie dobrej sytuacji gospodarczej w Polsce w okresie kryzysu gospodarczego w Europie. Analiza otrzymanych wyników wskazuje przy tym, że występowanie sztywności nominalnych nie rzutuje w istotny sposób na siłę wpływu podatków niezryczałtowanych na przebieg cyklu koniunkturalnego.

Badania empiryczne Talviego i Vegha (2005) oraz Bogdanova (2010) pokazują, że wbrew postulatom normatywnym reakcje polityki fiskalnej na fluktuacje gospodarcze mają często charakter procykliczny. W celu zbadania, czy polityka fiskalna w Polsce ma charakter pro- czy antycykliczny porównano kształtowanie się rzeczywistej luki produktowej, z hipotetyczną luką produktową, która miałaby miejsce, gdyby nie prowadzono aktywnej polityki fiskalnej. Uzyskano, że w przypadku braku prowadzenia aktywnej polityki fiskalnej wahania koniunktury cechowałyby się znacznie większą amplitudą. Zatem, podobnie jak u Mackiewicza (2010), otrzymano, że polityka fiskalna w Polsce ma charakter antycykliczny. Ciekawe pole do dalszych badań z zakresu cykliczności polityki fiskalnej w gospodarce polskiej stanowi analiza efektów działań dyskrecjonalnych i rozwiązań 
opartych na regułach, a także zbadanie, czy w Polsce siła oddziaływania aktywnej polityki fiskalnej jest odmienna $\mathrm{w}$ różnych fazach cyklu.

Na podstawie oszacowań cyklicznych komponentów dochodów i wydatków publicznych, zbadano także wpływ pasywnej polityki fiskalnej. Na gruncie modelu nowokeynesistowskiego uzyskano, że automatyczne stabilizatory wygładzają ok. 16\% fluktuacji gospodarczych w Polsce. Natomiast z oszacowań uwzględniających jedynie mechanizmy podażowe wynika, że automatyczne stabilizatory zmniejszają odchylenie standardowe luki produktowej o mniej niż 10\%. Badania, które przeprowadzili Dolls, Fuest i Peichl (2009) ukazują, że w krajach Unii Europejskiej efektywność pasywnej polityki fiskalnej jest zazwyczaj znacznie wyższa.

Znaczenie automatycznych stabilizatorów oraz antycyklicznej aktywnej polityki fiskalnej nabierze szczególnego znaczenia po wstąpieniu Polski do strefy euro, gdy polityka pieniężna nie będzie już mogła pełnić roli instrumentu przeciwdziałającego skutkom szoków asymetrycznych. Zdaniem Sławińskiego (2008) rozwiązaniem instytucjonalnym, które po wprowadzeniu euro mogłoby ułatwić prowadzenie polityki antycyklicznej, jest powołanie Rady Polityki Fiskalnej. Ponadto z przeprowadzonych oszacowań wynika, że w celu zwiększenia skuteczności automatycznych stabilizatorów wskazane byłoby podniesienie podatków dochodowych lub wydatków na pasywne formy przeciwdziałania bezrobociu. Działania takie mogłyby jednak odbić się niekorzystnie na poziomie aktywności gospodarczej. Warto również zaznaczyć, że progresja podatkowa w PIT nie ma kluczowego znaczenia dla działania tego podatku jako automatycznego stabilizatora koniunktury. Zniesienie trzeciej stawki podatkowej od 2009 roku wpłynęło na ograniczenie skuteczności PIT w łagodzeniu fluktuacji gospodarczych jedynie o ok. $8 \%$. 


\section{Zakończenie}

W pracy poddano analizie wpływ polityki fiskalnej na fluktuacje gospodarcze w Polsce. Znaczenie wydatków rządowych i podatków jako narzędzi oddziaływania na wahania koniunktury jest szczególnie widoczne w dobie kryzysu gospodarczego na świecie. Antycykliczna polityka fiskalna z reguły ma na celu stymulowanie agregatowego popytu. Jednocześnie jednak zmiany w poziomie wydatków rządowych oraz podatków wywierają również skutki podażowe. $Z$ tego względu w pracy zbadano zarówno popytowe, jak i podażowe efekty polityki fiskalnej w gospodarce polskiej.

W pierwszych dwóch rozdziałach, na podstawie dynamicznych, stochastycznych modeli równowagi ogólnej, omówiono teoretyczne mechanizmy podażowego oraz popytowego oddziaływania polityki fiskalnej na fluktuacje gospodarcze. Stanowią one punkt wyjścia do analiz empirycznych, przeprowadzonych w dalszej części pracy.

Teoretyczna analiza efektów podażowych polityki fiskalnej przedstawiona została w oparciu o modele realnego cyklu koniunkturalnego, w których przyjmuje się, że płace i ceny są doskonale elastyczne i natychmiast dostosowują się do poziomu równoważącego rynek. Na gruncie modeli RBC zmiany stóp podatkowych wywierają wpływ na wahania PKB głównie poprzez oddziaływanie na krańcowy produkt pracy oraz krańcowy produkt kapitału po opodatkowaniu. Natomiast zwiększanie wydatków rządowych finansowane zryczałtowanymi podatkami lub długiem publicznym powoduje wzrost PKB przede wszystkim poprzez efekt majątkowy. Jak wynika z prac Aschauera (1988) oraz Amblera, Bouakeza i Cardii (2010) efekty podażowe wydatków rządowych uzależnione są przy tym od kształtowania się krańcowej stopy substytucji pomiędzy konsumpcją prywatną a konsumpcją dóbr publicznych oraz od krańcowego produktu dóbr dostarczanych przez państwo. Ponadto, jak wskazują Baxter i King (1993), wzrost inwestycyjnych wydatków rządowych, poprzez podwyższenie kapitału publicznego, oddziałuje na możliwości wytwórcze gospodarki.

Uwzględnienie popytowego oddziaływania polityki fiskalnej jest możliwe na gruncie modeli nowej ekonomii keynesistowskiej, w których zakłada się występowanie sztywności nominalnych w gospodarce. Jednocześnie, podobnie jak modele RBC, opierają się one na podstawach mikroekonomicznych. Jak ukazuje Cardia (1995), im kontrakty płacowe słabiej reagują na sytuację na rynku pracy, tym silniejszy jest krótkookresowy wpływ wydatków rządowych na produkcję. Natomiast na podstawie analiz Linnemanna i Schaberta (2003) otrzymuje się, 
że skutki polityki fiskalnej w sytuacji występowania sztywności nominalnych cen $\mathrm{w}$ znacznym stopniu uzależnione są od sposobu prowadzenia polityki pieniężnej. Ponadto z symulacji Ravna, Schmitt-Grohe i Uribe (2006) oraz Galego, Lopez-Salido i Vallesa (2007) wynika, że siła popytowego oddziaływania polityki fiskalnej na gospodarkę uzależniona jest od występowania przyzwyczajeń konsumpcyjnych oraz udziału gospodarstw domowych nie podejmujących decyzji optymalizacyjnych, czyli tzw. gospodarstw niericardiańskich.

$\mathrm{Na}$ gruncie modelu RBC oraz modelu nowokeynesistowskiego, w trzecim i czwartym rozdziale pracy, poddano analizie podażowy oraz popytowy wpływ polityki fiskalnej na wahania koniunktury w Polsce. Teoretyczną podstawę analizy efektów podażowych stanowi model Hansena (1985). Skutki polityki fiskalnej w warunkach występowania sztywności nominalnych zbadano natomiast na podstawie modelu Smetsa i Woutersa (2003). Obydwa modele rozszerzono o dodatkowe założenia dotyczące polityki fiskalnej oraz zaimplementowano do warunków gospodarki polskiej poprzez estymację parametrów na podstawie danych z lat 1995-2010.

W pracy zbadano oddziaływanie w gospodarce polskiej trzech wariantów polityki fiskalnej:

- zwiększenia wydatków rządowych sfinansowanego deficytem budżetowym lub zgodnie z ekwiwalencją ricardiańską podatkami zryczałtowanymi, nie uzależnionymi od dochodu,

- podniesienia stopy opodatkowania dochodów,

- podwyższenia wydatków rządowych sfinansowanego podatkami niezryczałtowanymi, zależnymi od dochodu.

Na podstawie modelu podażowego, wykorzystując oszacowane dla gospodarki polskiej parametry uzyskano, że przejściowy wzrost wydatków rządowych o $1 \%$ PKB powoduje przejściowe zwiększenie produkcji o ok. 0,2\%. Otrzymano zatem podażowy mnożnik wydatków rządowych zbliżony do uzyskanych na gruncie modelu RBC oszacowań Bukowskiego i in. (2005). Przy uwzględnieniu efektów popytowych wpływ zmian wydatków rządowych na kształtowanie się PKB jest znacznie silniejszy. Z modelu uwzględniającego sztywności nominalne wynika bowiem, że zwiększenie wydatków rządowych o $1 \%$ PKB prowadzi do wzrostu produkcji o ok. $0,8 \%$. Porównując uzyskane w pracy rezultaty dla gospodarki polskiej z oszacowaniami otrzymanymi na podstawie modeli nowokeynesistowskich dla gospodarki amerykańskiej i strefy euro autorstwa Coenena i Strauba (2005), Ratto, Roegera i in't Velda (2008), czy Wielanda i in. (2012), zaobserwować można, że oddziaływanie wydatków rządowych na PKB jest w gospodarce polskiej relatywnie silne.

Zestawienie wyników analiz przeprowadzonych na podstawie modelu RBC i modelu nowokeynesistowskiego pokazuje, że występowanie efektów popytowych czterokrotnie zwiększa siłę oddziaływania wydatków rządowych na produkcję. Wyodrębnienie na gruncie modelu nowokeynesistowskiego efektów 
podażowych i popytowych prowadzi od zbliżonych wniosków. W wariancie modelu Smetsa i Woutersa, w którym nie występują sztywności nominalne wzrost wydatków rządowych o $1 \%$ PKB powoduje zwiększenie produkcji zaledwie o $0,25 \%$, natomiast występowanie dostosowań cenowych i płacowych typu Calvo (1983) sprawia, że produkcja ulega zwiększeniu dodatkowo o $0,55 \%$. W pracy potwierdzono zatem hipotezę, że popytowe oddziaływanie wydatków rządowych na fluktuacje PKB jest w gospodarce polskiej silniejsze niż ich oddziaływanie podażowe.

Dekompozycja oddziaływania wydatków rządowych na komponent popytowy i podażowy jest szczególnie interesująca w przypadku stawki płac oraz konsumpcji prywatnej, ponieważ efekty podażowe i popytowe wpływają na te zmienne w przeciwnych kierunkach. Funkcje reakcji na impuls wskazują, że wydatki rządowe oddziałują na rynek pracy głównie poprzez agregatowy popyt, a co za tym idzie podniesienie wydatków rządowych powoduje wzrost stawki płac. W przypadku konsumpcji z kolei, podobnie jak m.in. u Cogana i in. (2009), uzyskano, że efekt podażowy jest silniejszy niż efekt popytowy i w rezultacie wzrost wydatków rządowych poprzez efekt wypychania prowadzi do spadku konsumpcji prywatnej. Bouakez i Rebei (2007) oraz Gali, Lopez-Salido i Valles (2007) wskazują, że jedną z przyczyn ujemnej zależności pomiędzy konsumpcją prywatną i publiczną jest przyjęcie założenia o występowaniu w gospodarce homogenicznych gospodarstw domowych podejmujących decyzje optymalizacyjne. Dlatego rozszerzenie modelu nowokeynesistowskiego dla gospodarki polskiej o występowanie gospodarstw niericardiańskich, podejmujących decyzje na podstawie jedynie bieżącego dochodu, stanowi interesujący obszar do dalszych badań.

$\mathrm{Z}$ wykonanch na podstawie modelu realnego cyklu koniunkturalnego oraz modelu nowokeynesistowskiego symulacji dotyczących wpływu podniesienia stopy podatkowej na PKB wynika, że na skutek wzrostu opodatkowania dochodów następuje znaczne obniżenie się poziomu kapitału i zatrudnienia. Przy czym, o ile zatrudnienie wraca do poziomu wyjściowego relatywnie szybko, to negatywny wpływ wyższego opodatkowania na kształtowanie się ilości kapitału jest bardziej długotrwały. W efekcie obniżenia się obydwu czynników produkcji silnemu zmniejszeniu ulega również PKB. Z symulacji przeprowadzonych na podstawie modelu podażowego wynika, że przejściowe zwiększenie stopy opodatkowania dochodów o 1 pkt proc. powoduje przejściowe obniżenie się produkcji o ok. $2 \%$. Oszacowany negatywny podażowy wpływ zmian opodatkowania na produkcję jest zatem silniejszy niż w pracy Bukowskiego i in. (2005). Jednocześnie uwzględnienie sztywności nominalnych nie zwiększa siły odziaływania zmian stóp podatkowych na PKB. W pracy pozytywnie zweryfikowano więc hipotezę, że zmiany stóp podatkowych wpływają na kształtowanie się fluktuacji produkcji w większym stopniu poprzez efekty podażowe niż popytowe.

Jak wskazano powyżej, wzrost wydatków rządowych finansowany deficytem budżetowym prowadzi do wzrostu produkcji, natomiast podniesienie stopy 
podatkowej - do ograniczenia PKB. W pracy zbadano zatem, jakie są skutki podwyższenia wydatków rządowych sfinansowanego wyższym opodatkowaniem dochodów. Zarówno z analiz wykonanych na podstawie modelu RBC, jak i modelu nowokeynesistowskiego wynika, że finasowanie dodatkowych wydatków rządowych podatkami zależnymi od dochodu obniża poziom PKB. Analogiczne rezultaty dla gospodarki amerykańskiej uzyskali m.in. Totzek i Winkler (2010) oraz Uhlig (2010). Wnioski z przeprowadzonych symulacji są zatem odmienne niż wynikałoby to z podejścia czysto popytowego, nie uwzględniającego mechanizmów mikroekonomicznych. Na podstawie otrzymanych rezultatów odrzucono hipotezę, że w warunkach gospodarki polskiej wydatki rządowe silniej niż zmiany stóp podatkowych wpływają na wahania PKB. Jednocześnie wyniki symulacji pokazują, że wybór sposobu finansowania wydatków rządowych wywiera kluczowy wpływ na charakter oddziaływania polityki fiskalnej na gospodarkę.

W pracy podjęto również próbę oszacowania efektów polityki fiskalnej w dekompozycji na poszczególne wydatki publiczne oraz podatki. Funkcje reakcji na impuls wskazują, że zwiększenie publicznych wydatków majątkowych wywiera silniejszy i bardziej długotrwały wpływ na gospodarkę niż podnoszenie wydatków bieżących. Ponadto przeprowadzone wyniki symulacji potwierdzają hipotezę, że wydatki substytucyjne względem konsumpcji prywatnej w mniejszym stopniu przyczyniają się do stymulowania aktywności gospodarczej niż wydatki rządowe niebędące substytutami konsumpcji prywatnej. Nie została natomiast potwierdzona hipoteza dotycząca wpływu zmian opodatkowania poszczególnych czynników produkcji na PKB. Jak wynika bowiem z wykonanych analiz wzrost opodatkowania wynagrodzeń silniej oddziałuje na ograniczenie produkcji niż wzrost opodatkowania dochodów z kapitału. W przypadku zwiększenia podatków nakładanych na wynagrodzenia silniejszemu ograniczeniu ulega produkcja, zatrudnienie, a także, co szczególnie intersujące, poziom kapitału. Warto przy tym zaznaczyć, że wymienione rezultaty dotyczą krótkookresowego oddziaływania przejściowych zmian podatkowych, podczas gdy podwyższenie opodatkowania kapitału wywiera szczególnie silny negatywny wpływ w perspektywie długookresowej i w przypadku zmian trwałych, co pokazują m.in. analizy Bukowskiego $\mathrm{i}$ in. (2005).

$\mathrm{W}$ ostatnim rozdziale, na podstawie wyznaczonych na gruncie modelu realnego cyklu koniunkturalnego oraz modelu nowokeynesistowskiego funkcji reakcji na impuls, oszacowany został wpływ aktywnej i pasywnej polityki fiskalnej na przebieg cyklu koniunkturalnego w Polsce. W celu wyodrębnienia aktywnej i pasywnej polityki fiskalnej dokonano dekompozycji poszczególnych kategorii budżetowych na komponent strukturalny i cykliczny. W pracy wykorzystano metodę wyodrębniania cyklicznych i strukturalnych komponentów budżetowych opartą na szacunkach luki produktowej oraz elastyczności dochodów i wydatków budżetowych względem PKB, stosowaną m.in. w pracach van den Noorda (2000) oraz Fedelino, Ivanovy i Hortona (2009). Okazało się, że wśród dochodów 
publicznych najniższą elastycznością względem PKB cechują się wpływy z podatków pośrednich. W przypadku PIT, CIT oraz składek na ubezpieczenie społeczne oszacowania elastyczności nie różnią się w sposób statystycznie istotny od jedności. Natomiast najwyższą, w ujęciu bezwzględnym, elastyczność względem PKB uzyskano dla wydatków na pasywne formy przeciwdziałania bezrobociu.

$\mathrm{Na}$ podstawie kształtowania się strukturalnych, tj. skorygowanych o komponenty cykliczne, wpływów podatkowych oraz wydatków rządowych zbadano, w jaki sposób aktywna polityka fiskalna oddziaływała na przebieg cyklu koniunkturalnego $\mathrm{w}$ gospodarce polskiej. Z przeprowadzonych analiz wynika, że w przypadku braku prowadzenia aktywnej polityki fiskalnej wahania koniunktury cechowałyby się znacznie większą amplitudą. Potwierdzona została zatem hipoteza, że polityka fiskalna w Polsce ma charakter antycykliczny. W szczególności oszacowano, że zmniejszenie strukturalnych dochodów podatkowych, które miało miejsce począwszy od 2007 roku, przełożyło się na podwyższenie poziomu PKB w latach 2009-2010 o ponad 1\%, przyczyniając się do relatywnie dobrej sytuacji gospodarczej w Polsce w okresie kryzysu gospodarczego w Europie. Również wydatki rządowe, choć w relatywnie mniejszym stopniu, wpłynęły na wzrost PKB w Polsce w tym okresie. Pozytywnie zweryfikowana została zatem hipoteza, że aktywna polityka fiskalna miała wpływ na złagodzenie negatywnych skutków kryzysu.

Oddziaływanie pasywnej polityki fiskalnej na przebieg cyklu koniunkturalnego oszacowano na podstawie cyklicznych komponentów dochodów i wydatków publicznych. $\mathrm{Na}$ gruncie modelu nowokeynesistowskiego uzyskano, że automatyczne stabilizatory koniunktury wygładzają ok. $16 \%$ fluktuacji gospodarczych w Polsce. Natomiast zgodnie z oszacowaniami uwzględniającymi jedynie mechanizmy podażowe, pasywna polityka fiskalna wpłynęła na zmniejszenie odchylenia standardowego luki produktowej w badanym okresie o mniej niż $10 \%$. Z badań, które przeprowadzili Dolls, Fuest i Peichl (2009) wynika, że w większości krajów Unii Europejskiej efektywność automatycznych stabilizatorów jest znacznie wyższa.

Jak wskazują m.in. Stiglitz (1988), Belka (2003) oraz Wojtyna (2003) automatyczne stabilizatory koniunktury stanowią z reguły szybsze i bardziej przewidywalne narzędzie stabilizowania koniunktury niż aktywna polityka fiskalna. Porównując oddziaływanie aktywnej i pasywnej polityki fiskalnej na przebieg cyklu koniunkturalnego w Polsce zaobserwować jednak można, że na ograniczenie fluktuacji PKB miały przede wszystkim wpływ zmiany strukturalnych dochodów podatkowych oraz wydatków rządowych. Nie została zatem potwierdzona hipoteza, dotycząca silniejszego oddziaływania pasywnej polityki fiskalnej na wygładzenie wahań koniunktury w Polsce.

Z przeprowadzonych oszacowań wynika, że w celu zwiększenia skuteczności antycyklicznej funkcji pasywnej polityki fiskalnej wskazane byłoby podniesienie podatków dochodowych lub wydatków na pasywne formy przeciwdziałania 
bezrobociu. Warto jednocześnie pamiętać, że działania takie mogłyby odbić się niekorzystnie na długofalowym poziomie aktywności gospodarczej. Analiza, w jakim stopniu występuje wymienność pomiędzy siłą działania automatycznych stabilizatorów koniunktury a konkurencyjnością gospodarki stanowi interesujące pole do dalszych badań.

Władze fiskalne mogą również oddziaływać na zmniejszenie fluktuacji gospodarczych poprzez politykę aktywną. Przeprowadzone badania umożliwiają porównanie skutków dwóch wariantów aktywnej polityki fiskalnej: zwiększenia wydatków rządowych oraz obniżenia opodatkowania dochodów. Zarówno z modelu realnego cyklu koniunkturalnego, jak i modelu nowokeynesistowskiego wynika, że w gospodarce polskiej obniżanie stopy podatkowej silniej wpływa na wzrost PKB niż podnoszenie wydatków rządowych. Podatki mocniej oddziałują na obydwa czynniki produkcji - zarówno kapitał, jak i zatrudnienie. Niższe opodatkowanie prowadzi ponadto do wzrostu konsumpcji i inwestycji, podczas gdy wzrost wydatków rządowych do ich wypychania. Zatem na podstawie analizowanych w pracy modeli otrzymuje się, że obniżanie stopy podatkowej stanowi efektywniejszą metodę stymulowania gospodarki niż podnoszenie wydatków rządowych. Warto jednocześnie pamiętać, o czym wspomina Owsiak (2012), że stymulowanie gospodarki poprzez obniżanie stóp podatkowych przyczynia się do zwiększenia nierówności dochodowych.

Otrzymane w pracy wnioski dotyczą oddziaływania polityki fiskalnej w ramach typowych fluktuacji gospodarczych. W warunkach głębokiej recesji mnożniki fiskalne mogą kształtować się na odmiennym poziomie, na co wskazują Blanchard i Leigh (2013) w szeroko komentowanym na świecie raporcie MFW dotyczącym skutków konsolidacji fiskalnych w krajach dotkniętych kryzysem.

W świetle przytoczonego raportu szczególnego znaczenia nabiera pytanie o optymalny kształt polityki fiskalnej w warunkach recesji. Z jednej strony, wzrost mnożników fiskalnych w okresie kryzysu gospodarczego przemawia za prowadzeniem ekspansywnej polityki fiskalnej. $Z$ drugiej strony, w dłuższej perspektywie zwiększa ona ryzyko wzrostu relacji długu publicznego do PKB, którego możliwe niebezpieczne następstwa w obrazowy sposób ukazuje przypadek Grecji. Burzliwe dyskusje ekonomistów, zarówno w Polsce, jak i na świecie, pokazują, że $\mathrm{w}$ tej kwestii nie został jeszcze wypracowany konsens. 


\section{Literatura}

Abel A.B. (1990), Asset Prices under Habit Formation and Catching Up with the Joneses, „The American Economic Review Papers and Proceedings", vol. 80

Achmed S. (1986), Temporary and Permanent Government Spending in an Open Economy: Some Evidence from the United Kingdom, „Journal of Monetary Economics”, vol. 17

Acocella N. (2002), Zasady polityki gospodarczej, Wyd. Nauk. PWN, Warszawa

Ahmed S., B.S. Yoo (1995), Fiscal Trends in Real Economic Aggregates, „Journal of Money, Credit, and Banking", vol. 27

Adolfson M., S. Laseen, J. Linde, M. Villani (2008), Evaluation an estimated new Keynesian small open economy model, ,Journal of Economic Dynamics and Control”, no. 32,

Adolfson M., J. Linde, M. Villani (2007), Forecasting Performance of an Open Economy DSGE Model, „Econometric Reviews”, vol. 26, no. 2-4

Afonso A., J. Baxa, M. Slavík (2011), Fiscal Developments and Financial Stress. A Threshold VAR Analysis, ECB Working Paper, no. 1319

Afonso A., R. Sousa (2009), The Macroeconomic Effects of Fiscal Policy, European Central Bank, Working Paper Series, no. 991

Afonso A., R.M. Sousa (2011), The macroeconomic effects of fiscal policy in Portugal: a Bayesian SVAR Analysis, „Portuguese Economic Journal”, vol. 10(1)

Aizenman J., G.K. Pasricha (2011), Net Fiscal Stimulus During the Great Recession, NBER Working Paper, no. 16779

Akerlof G.A, J.L. Yellen (1985), A Near-Rational Model of the Business Cycle, with Wage and Price Inertia, „Quarterly Journal of Economics”, vol. 100

Alesina A., S. Ardagna (2010), Large Changes in Fiscal Policy: Taxes versus Spending, „Tax Policy and the Economy", vol. 24

Alesina A., R. Perotti (1996), Fiscal Discipline and the Budget Process, „American Economic Review", vol. 86(2)

Alesina A., G. Tabellini (2008), Why is fiscal policy often procyclical?, „Journal of the European Economic Association", September

Altug S. (1989), Time-to-Build and Aggregate Fluctuations: Some New Evidence, „International Economic Review", vol. 40, no. 4

Ambler S., H. Bouakez, E. Cardia (2010), Does the Crowding in Effect of Public Consumption Undermine Neoclassical Models, CIREQ Working Paper, Concordia University

Amano R.A., T.S. Wirjanto (1997), Intertemporal Substitution and Government Spending, „The Review of Economics and Statistics", no. 1

Ando A., F. Modigliani (1957), Tests of the Life Cycle Hypothesis of Savings, „Bulletin” vol. 19, Oxford University, Institute of Economics and Statistics

Ando A., F. Modigliani (1963) The Life-cycle Hypothesis of Saving: Aggregate Implications and Tests, „American Economic Review”, vol. 53, no. 1

Angeletos G.M., V. Panousi (2009), Revisiting the Supply-Side Effects of Government Spending, Finance and Economics Discussion Series, Divisions of Research \& Statistics and Monetary Affairs, Federal Reserve Board, Washington

Angeloni I., G. Coenen, F. Smets (2003), Persistence, the transmission mechanism and robust monetary policy, „Scottish Journal of Political Economy”, vol. 50 (5) 
Ardagna S. (2001), Fiscal Policy Composition, Public Debt, and Economic Activity, „Public Choice", vol. 109

Ardagna S. (2006), Fiscal Policy in Unionized Labor Markets, Harvard University Working Paper Arestis P. (2009), New Consensus Macroeconomics: A Critical Appraisal, Working Paper, no. 0509, Cambridge Centre for Economic and Public Policy

Arnold J. (2008), Do tax structures affect aggregate economic growth? Empirical evidence from a panel of OECD countries, OECD, Economic Department, Working Paper, no. 643, Paris

Aschauer D. (1985), Fiscal Policy and Aggregate Demand, „American Economic Review”, vol. 75

Aschauer D. (1988), The Equilibrium Approach to Fiscal Policy, „Journal of Money, Credit and Banking", no. 20

Assarsson B., R. Gidehag, G. Zettegren (1999), Fiscal policy in Sweden - an analysis of the budget over the business cycle, [w:] Indicators of Structural Budget Balances, Banca D'Italia

Auerbach A.J. (2009), Implementing the New Fiscal Policy Activism, „American Economic Review", vol. 99(2)

Auerbach A.J., Y. Gorodnichenko (2011), Fiscal Multipliers in Recession and Expansion, NBER Working Paper, no. 17447

Bailey M. J. (1971), National Income and the Price Level, McGraw-Hill, New York

Bailey S. (1995), Public Sector Economics, Macmillan Press Ltd, Houndmills

Baranowski P. (2008), Reguła Taylora i jej rozszerzenia, „Gospodarka Narodowa”, nr 7-8

Baranowski P. (2011), Efekty oczekiwanego i nieoczekiwanego zacieśnienia polityki pieniężnej w świetle hybrydowego modelu DSGE dla gospodarki Polski, „Ekonomista”, nr 3

Baranowski P., G. Szafrański (2011), Reakcja gospodarki polskiej na szok polityki pieniężnej w matym modelu DSGE - na ile wybór metody estymacji determinuje wyniki?, http://www.nbp.pl/ badania/konferencje/2011/mtm/files/Reakcja_gospodarki_polskiej_na_szok_polityki_pienieznej.pdf

Barillas F., Colacito R., Kitao S., Matthes Ch., Sargent T. J., Shin Y. (2007), Practicing Dynare, http://www.dynare.org

Barrell R., A. Pina (2002), How important are automatic stabilizers in Europe? A stochastic simulation assessment, National Institute of Economic and Social Research, Discussion Papers, no. 196

Barro R. (1974), Are Government Bonds Net Wealth?, ,Journal of Political Economy”, vol. 82

Barro R. (1979), On the Determination of the Public Debt, ,Journal of Political Economy”, vol. 87

Barro R. (1981) Output Effects of Government Purchases, „Journal of Political Economy”, vol. 89

Barro R. (1989), The Neoclassical Approach to Fiscal Policy, [w:] R. Barrro (ed.) Modern Business Cycle Theory, Harvard University Press, Cambridge Mass.

Barro R. (1990), Government Spending in a Simple Model of Economic Growth, „Journal of Political Economy", vol. 98

Baum A., G.B. Koester (2011), The impact of fiscal policy on economic activity over the business cycle-evidence form a threshold VAR analysis, Deutsche Bundesbank, Discussion Paper, no. 03

Baxter M., R.G. King (1993), Fiscal Policy in General Equilibrium, „The American Economic Review", vol. 83, no. 3

Baxter M., R.G. King (1995), Measuring Business Cycles: Approximate Band-Pass Filters for Economic Time Series, NBER Working Paper, no. 5022

Belka M. (2003), Co to sa zdrowe finanse publiczne?, [w:] Polska transformacja - sukcesy i bariery. Refleksje z okazji jubileuszu Profesora Jana Mujżela, Wydawnictwo Uniwersytetu Łódzkiego, Łódź

Benhabib J., R. Rogerson, R. Wright (1991), Homework in Macroeconomics: Household Production and Aggregate Fluctuations, „Journal of Political Economy”, December 
Bernanke B., M. Gertler, S. Gilchrist (1999), The Financial Accelerator in a Quantitative Business Cycle Framework, [w:] J.B. Taylor, M. Woodford (ed.), Handbook of Macroeconomics, Elsevier, North-Holland, Amsterdam

Bernheim B.D. (1987), Ricardian Equivalence: An Evaluation of Theory and Evidence, NBER Working Paper, no. 2330

Bernheim B.D. (1991), How Strong are Bequest Motives? Evidence Based on Estimates of the Demand for Life Insurance and Annuities, „Journal of Political Economy”, vol. 99

Bewley T.F. (1999), Why Wages Don't Fall during a Recession?, Harvard University Press, Cambridge Mass.

Bils M., P.J. Klenow (2004), Some Evidence on the Importance of Sticky Prices, „Journal of Political Economy", vol. 112 (5)

Binder A.S., Solow R.M. (1973), Does Fiscal Policy Matter?, „Journal of Public Economics”, November

Blanchard O. (1990), Suggestions for a New Set of Fiscal Indicators, OECD, Economics and Statistics Working Papers, no. 24

Blanchard O. (2009), The State of Macro, „Annual Review of Economics”, no. 1

Blanchard O., R. Perotti (2002), An Empirical Characterization of the Dynamic Effects of Changes in Government Spending and Taxes on Output, „Quarterly Journal of Economics”, vol. 117

Blanchard O., D. Leigh (2013), Growth Forecast Errors and Fiscal Multipliers, IMF Working Paper, no. 1

Blaug M. (1994), Teoria ekonomii. Ujęcie retrospektywne, PWN, Warszawa

Bludnik I. (2010), Nowa synteza neoklasyczna w makroekonomii, „Bank i Kredyt”, nr 2

Bogdanov B. (2010), Cyclicality of Fiscal Policy over the Business Cycle: An Empirical Study on Developed and Developing Countries, Agency for Economic Analysis and Forecasting, Working Paper Series, no. 1

Borys P., P. Ciżkowicz, A. Rzońca (2011), Panel data evidence on non-Keynesian effects of fiscal policy in the EU New Member, MPRA Paper, no. 32696

Botman D., M. Kumar (2006), Fundamental Determinants of the Effects of Fiscal Policy, IMF Working Paper, no. 72

Bouakez H., N. Rebei (2007), Why does private consumption rise after a government spending shock?, „Canadian Journal of Economics”, vol. 40

Branch W.A., B. McGough (2009), A New Keynesian Model with Heterogeneous Expectations, „Journal of Economic Dynamics and Control”, vol. 33 (5)

Brandner P., L. Diebalek, H. Schuberth (1998), Structural Budget Deficits and Sustainability of Fiscal Positions in the European Union, Oesterreichische Nationalbank, Working Paper, no. 26.

Brock W., S. Turnovsky (1981), The Analysis of Macroeconomic Policies in Perfect Foresight Equilibrium, „International Economic Review”, vol. 22

Brumberg R., F. Modigliani (1954), Utility Analysis and the Consumption Function, [w:] Kurihara K. (ed.), Post Keynesian Economics, Rutgers University Press, Brunswick, N. J.

Brunila A., M. Buti, J. in 't Veld (2002), Fiscal policy in Europe: how effective are automatic stabilisers?, European Economy, Economic Papers, no. 177

Brunila A., M. Tujula (1999), Indicators of the cyclically adjusted budget balance, [w:] Indicators of Structural Budget Balances, Banca D'Italia

Bry G., C. Boschan (1971), Cyclical Analysis of Time Series: Selected Procedures and Computer Programs, National Bureau of Economic Research Technical Paper, no. 20

Brzoza-Brzezina M., K. Makarski (2009), Credit Crunch in a Small Open Economy, MPRA Paper, no. 18595.

Buiter W.H. (1990), Principles of Budgetary and Financial Policy, The MIT Press, Cambridge Mass.

Buti M., G. Giudice (2002), EMU's Fiscal Rules: What Can and Cannot Be Exported, European Commission Working Paper, 30 April 
Bukowski M., P. Kowal, P. Lewandowski, J. Zawistowski (2005), Struktura i poziom wydatków sektora finansów publicznych a sytuacja na rynku pracy. Doświadczenia międzynarodowe i wnioski dla Polski, NBP, Departament Komunikacji Społecznej, Warszawa

Calderón C., K. Schmidt-Hebbel (2003), Macroeconomic Policies and Performance in Latin America, ,Journal of International Money and Finance”, vol. 22

Calvo G. (1983), Straggered Prices in a Utility-Maximizing Framework, „Journal of Monetary Economics", no. 12

Campbell J.Y., N.G. Mankiw (1989), Consumption, Income, and Interest Rates: Reinterpreting the Time Series Evidence, „NBER Macroeconomics Annual”, MIT Press, Cambridge Mass.

Canova F. (2007), Methods for Applied Macroeconomic Research, Princeton University Press, Princeton

Canova, F., L. Sala (2009), Back to square one: identification issues in DSGE models, „Journal of Monetary Economics", vol. 56

Canova F., Paustian, M (2010), Measurement with Some Theory: a New Approach to Evaluate Business Cycle Models, Barcelona Economics Working Paper, no. 511

Caraiani P. (2010), Fiscal policy in CEE Countries. Evidence from Czech Republic, Hungary, Poland and Romania, Cerge EI Working Paper

Cardia E. (1995), The effects of fiscal policies in a general equilibrium model with nominal wage contracts, „Economic Letters”, no. 49

Carroll Ch.D, J.R. Overland, D.N. Weil, (1995), Saving and Growth with Habit Formation, FEDS Working Paper, no. 95

Cecchetti S.G. (1986), The Frequency of Price Adjustment: A Study of the Newsstand Prices of Magazines, „Journal of Econometrics”, August

Chahrour R., S. Schmitt-Grohe, M. Uribe (2012), A Model-Based Evaluation of the Debate on the Size of the Tax Multiplier, „American Economic Journal: Economic Policy”, vol. 4(2)

Chalk N. (2002), Structural Balances and All That: Which Indicators to Use in Assessing Fiscal Policy, IMF, Working Paper, no. 101

Chari V.V., P.J. Kehoe, E.R. McGrattan (2000), Sticky Price Models of the Business Cycle: Can the Contract Multiplier Solve the Persistence Problem?, „Econometrica”, vol. 68, no. 5

Chintagunta P., E. Kyriazidou, J. Perktold (2001), Panel Data Analysis of Household Brand Choices, „Journal of Econometrics”, vol. 103

Christiano L.J., M. Eichenbaum (1992), Current Real Business Cycle Theory and Aggregate Labor Market Fluctuations, „American Economic Review”, vol. 82

Christiano L.J., M. Eichenbaum, Ch.L. Evans (1998), Monetary Policy Shocks: What Have We Learned and to What End?, [w:] J.B. Taylor, M. Woodford(eds.), Handbook of Macroeconomics, North-Holland Publishing, Amsterdam

Christiano L.J., M. Eichenbaum, Ch. Evans (2005), Nominal Rigidities and the Dynamic Effects of a Shock to Monetary Policy, „Journal of Political Economy”, vol. 1, no. 113

Christiano L.J., M. Eichenbaum, S. Rebelo (2009), When is the government spending multiplier large?, NBER Working Paper, no. 15394

Christiano L.J., M. Eichenbaum, R. Vigfusson (2003), What happens after a Technology Shock?, NBER Working Paper, no 9819

Christiano L.J., T.J. Fitzgerald (1999), The Band Pass Filter, Working Paper, no. 9906, Federal Reserve Bank of Cleveland

Clarida R., J. Gali, M. Gertler (1999), The Science of Monetary Policy: A New Keynesian Perspective, „Journal of Economic Literature”, vol. 37, no. 4

Coenen G., C. Erceg, C. Freedman, D. Furceri, M. Kumhof, (2010), Effect of Fiscal Stimulus in Structural Models, IMF Working Paper, no. 1073 
Coenen G., R. Straub (2005), Does government spending crowd in private consumption? Theory and empirical evidence for the euro area, International Finance, vol. 8(3)

Cogan J.F., T. Cwik, J.B. Taylor, V. Wieland (2009), New Keynesian versus Old Keynesian Government Spending Multipliers, NBER Working Paper, no. 14782

Cooley T.F., G.D. Hansen (1989), Inflation Tax in a Real Business Cycle Model, „American Economic Review", no. 79

Cooper R.W. (1997), Business Cycles: Theory, Evidence and Implications, NBER Working Paper, no. 5994

Coricelli F. (2004), Fiscal Policy In an Enlarged EU, Revue de l'OFCE - Special Issue

Coricelli F., V. Ercolani (2002), Cyclical and Structural deficits on the Road to Accession: Fiscal Rules for an Enlarged European Union, Centre for Economic Policy Research, Discussion Paper Series, no. 3672

Czyżewski A., N. Łapińska-Sobczak (2001), Zatrudnienie i bezrobocie a płace i koszty pracy w wybranych krajach Unii Europejskiej, „Ekonomista”, nr 4

Danthine J.P., A. Kurmann (2004), Fair Wages in a New Keynesian Model of the Business Cycle, „Review of Economic Dynamics”, vol. 7 (1)

Deaton A. (1992), Understanding Consumption, Clarendon Lectures in Economics, Clarendon Press, Oxford

De Cos P.H. (1999), Some considerations regarding the calculation of cyclically adjusted balances, [w:] Indicators of Structural Budget Balances, Banca D'Italia

De Grauwe P. (2008), DSGE-Modelling When Agents Are Imperfectly Informed, Working Paper, no 879, European Central Bank, Frankfurt

DeJong D.N., B.F. Ingram, Ch.H. Whiteman (2000), A Bayesian Approach to Dynamic Macroeconomics, ,Journal of Econometrics”, vol. 98

Dejong D.N., Ch. Dave (2007), Structural Macroeconometrics, Princeton University Press, Princeton

Devereux M.B., Head A., Lapham B. (1996), Monopolistic Competition, Increasing Returns, and the Effects of Government Spending, ,Journal of Money, Credit and Banking”, vol. 28, no. 2

Devries P., J. Guajardo, D. Leigh i A. Pescatori (2011), New Action-based Dataset of Fiscal Consolidation, IMF Working Paper, no. 128

Dhyne E., L.J. Àlvarez, H. le Bihan, G. Veronese, D. Dias, J. Homann, N. Jonker, P. Lunnemann, F. Rumler, J. Vilmunen (2006), Price Changes in the Euro Area and the United States: Some Facts from Individual Consumer Price Data, ,Journal of Economic Perspectives, vol. 20, no. 2

Dickens W.T., L. Goette, E.L. Groshen, S. Holden, J. Messina, M.E. Schweitzer, J. Turunen, M.E. Ward (2006), How Wages Change: Micro Evidence from the International Wage Flexibility Project, European Central Bank Working Paper, no 697

Dixit A., J.E. Stiglitz (1977), Monopolistic Competition and Optimum Product Diversity, „American Economic Review", vol. 67

Dolls M., C. Fuest, A. Peichl (2009), Automatic Stabilizers and Economic Crisis: US vs. Europe, The Institute for the Study of Labor, Discussion Paper, no. 4310

Domański Cz., K. Pruska (2000), Nieklasyczne metody statystyczne, PWE, Warszawa

Dotsey M. (1994), Some Unpleasant Supply Side Arithmetic, „Journal of Monetary Economics”, vol. 33

Dotsey M., R.G. King, A.L. Wolman (1999), State Dependent Pricing and the General Equilibrium Dynamics of Money and Output, „Quarterly Journal of Economics”, vol. CXIV, issue 2

Działo J. (2012), Dlaczego trudno jest prowadzić „,dobrą” polityke fiskalna??, „Gospodarka Narodowa”, nr 1-2

Erceg Ch.J., D.W. Henderson, A.T. Levin (2000), Optimal monetary policy with staggered wage and price contracts, „Journal of Monetary Economics”, vol. 46

Eggertsson G. (2008), Can Tax Cuts Deepen Recessions?, Federal Reserve Bank of New York, December 
Eggertsson G. (2010), The Paradox of Toil, Federal Reserve Bank of New York Staff Report, no. 433 Eggertsson G. (2011), What fiscal policy is effective at zero interest rates?, „NBER Macroeconomic Annual", University of Chicago Press

Eggertsson G., P. Krugman (2012), Debt, Deleveraging, and the Liquidity Trap, „Quarterly Journal of Economics", vol. 127 (3)

European Commission (2000), European Economy. Public finances in EMU - 2000, Office for Official Publications of the EC

European Commission (2001), European Economy. Public finances in EMU - 2001, Office for Official Publications of the EC

European Commission (2002), Communication from the Commission to the Council and the European Parliament. Strengthening the co-ordination of budgetary policies, COM (2002) 668(01)

European Commission (2003), Commission Recommendation on the Broad Guidelines of the Economic Policies of the member States and the Community (for the 2003-2005 period), Brussels, COM (2003) 170

European Commission (2008),EMU@10 Successes and challenges after 10 years of Economic and Monetary Union, European Economy 2

European Commission (2010), Specifications on the implementation of the Stability and Growth Pact and Guidelines on the format and content of Stability and Convergence, http://ec.europa. eu/economy_finance/articles/euro/documents/com_367_code_en.pdf

European Commission (2011), Public Finances in EMU -2011 , Office for Official Publications of the EC

Fairise X., F. Langot (1994), Labor productivity and the business cycle: Can R.B.C. models be saved?, „European Economic Review”, vol. 38, issue 8

Fatas A., I. Mihov (2001), The Effects of Fiscal Policy on Consumption and Employment: Theory and Evidence, CEPR Discussion Papers, no. 2760

Fedelino A., A. Ivanova, M. Horton (2009), Computing Cyclically Adjusted Balances and Automatic Stabilizers, IMF, Fiscal Affairs Department, Technical Notes and Manuals, November

Fernandez-Villaverde J. (2010), The econometrics of DSGE model, „SERIEs Journal of Spanish Economic Association", no. 1

Ferroni F. (2010), Did Tax Policies Mitigate US Business Cycles?, Banque de France, Working Paper, no 296

Fisher S. (1977), Long-Term Contracts, Rational Expectations, and the Optimal Money Supply Rule, „Journal of Political Economy”, February

Fisher J. (2006), The Dynamic Effects of Neutral and Investment-Specific Technology Shocks, „Journal of Political Economy”, vol. 114 (3)

Franco D. (1999), Structural Budget Balances in the Stability and Growth Pact Framework, [w:] Indicators of Structural Budget Balances, Banca D'Italia

Franses P.H., R. Paap, D. Fok (2005), Performance of Seasonal Adjustment Procedures: Simulation and empirical results, OECD Workshop on International Development of Business and Consumer Tendency Surveys.

Friedman M., A. Schwartz (1963), A Monetary History of United States, 1867-1960, Princeton, Princeton University Press.

Fuhrer J.C. (2000), Habit Formation in Consumption and its Implications for Monetary Policy, „American Economic Review”, vol. 90

Gajewski P. (2011), Doświadczenia z reform fiskalnych w okresie tworzenia Unii Gospodarczej $i$ Walutowej, „Gospodarka Narodowa”, nr 1-2

Gali J. (2008), Monetary Policy, Inflation and the Business Cycle. An Introduction to the New Keynesian Framework, Princeton University Press, Princeton

Gali J. (2009), The New Keynesian Approach to Monetary Policy Analysis: Lessons and New Directions, http://www.crei.cat/people/gali/jg09cfs.pdf 
Gali J., M. Gertler, J.D. Lopez-Salido (2005), Robustness of the estimates of the hybrid New Keynesian Phillips curve, ,Journal of Monetary Economics”, vol. 52

Gali J., M. Gertler (2007), Macroeconomic Modeling for Monetary Policy Evaluation, „Journal of Economic Perspectives", vol. 21 (4).

Gali J., J.D. Lopez-Salido, J. Valles (2007), Understanding the effects of government spending on consumption, „Journal of the European Economic Association”, vol. 5

Gali J., R. Perotti (2003), Fiscal Policy and Monetary Integration in Europe, „Economic Policy”, no. 18 (37)

Gali J., P. Rabanal (2004), Technology Shocks and Aggregate Fluctuations: How Well Does the RBS Model Fit Postwar U.S. Data?, NBER Working Paper, no. 10636

Gavin M., R. Hausmann, R. Perotti, E. Talvi (1996), Managing Fiscal Policy in Latin America and the Caribbean: Volatility, Procyclicality and Limited Credithwothiness, Inter-American Development Bank, Working Paper, no. 326

Gertler M., J. Leahy (2006), A Phillips Curve with an Ss Foundation, NBER Working Paper, no. 11971

Ghironi F., M.J. Melitz (2005), International Trade and Macroeconomic Dynamics with Heterogeneous Firms, „Quarterly Journal of Economics”, vol. 120 (3)

Giavazzi F., M. Pagano (1996), Non-Keynesian Effects of Fiscal Policy Changes: International Evidence and the Swedish Experience, NBER Working Paper, no. 5332.

Giorno C., P. Richardson, D. Roseveare, P. van den Noord (1995), Potential Output, Output Gap and Structural Budget Balances, „OECD Economic Studies”, no. 24

Giordano R., S. Momigliano, S. Neri, R. Perotti (2007), The effects of fiscal policy in Italy: Evidence from a VAR model, „European Journal of Political Economy”, vol. 23

Golinelli R., S. Momigliano (2006), The Real-Time Determinants of Fiscal Policy in the Euro Area: Fiscal Rules, Cyclical Conditions and Elections, Banca d'Italia, Working Paper, no. 60

Golosov M., R.E. Lucas (2003), Menu Costs and Phillips Curves, NBER Working Paper, no. 10187

Goodfriend M., R.G. King (1997), The New Neoclassical Synthesis and the Role of Monetary Policy, NBER Macroeconomics Annual

Goodwin R. M. (1967), A Growth Cycle, [w:] C.H. Feinstein (ed.), Socialism, Capitalism and Economic Growth, Cambridge University Press, Cambridge

Góra M. (2005), Trwale wysokie bezrobocie w Polsce. Wyjaśnienia i propozycje, „Ekonomista”, nr 1

Góra M., O. Rohozynsky, I. Sinitsina, M. Walewski (2008), Social Security Driven Tax Wedge and its Effects on Employment and Shadow Employment, ESCIRRU Working Paper, no. 08

Grabek G., B. Kłos (2008), Wybrane skutki przystapienia małej otwarte gospodarki do unii walutowej, Instytut Ekonomiczny NBP, Warszawa

Grabek G., B. Kłos, G. Utzig-Lenarczyk (2007), SOE-PL-model DSGE małej otwartej gospodarki estymowany na danych polskich, NBP, Departament Komunikacji Społecznej, Warszawa

Grabek G., B. Kłos, G. Koloch (2010), SOEPL 2009 - Model DSGE matej otwartej gospodarki estymowany na polskich danych. Specyfikacja, oceny parametrów, zastosowania, NBP, Materiały i Studia, zeszyt nr 251

Gradzewicz M., K. Makarski (2009), The Macroeconomic Effects of Losing Autonomous Monetary Policy after the Euro Adoption in Poland, NBP, Working Paper, nr 58

Gramlich E.M., (1994), Infrastructure Investment: A Review Essay, „Journal of Economic Literature", vol. 32

Greenwood J., Z, Hercowitz, G.W. Huffmann (1988), Investment, Capacity Utilization and the Real Business Cycle, „American Economic Review”, vol. 78 (2)

Griffoli T.M. (2007), Dynare User Guide. An introduction to the solution and estimation of DSGE models, http://www.dynare.org

Guziejewska B. (2010a), Finanse publiczne wobec wyzwań globalizacji, Poltext, Warszawa 
Guziejewska B. (2010b), Szoki dochodowe w finansach samorzadu terytorialnego - przyktad Samorządu Województwa Łódzkiego, [w:] L. Patrzałek (red.), Gospodarka finansowa jednostki samorzadu terytorialnego, Wydawnictwo Wyższej Szkoły Bankowej, Poznań

Hall R.E. (2009), By How Much Does GDP Rise If the Government Buys More Output?, Brookings Papers on Economic Activity, FallHansen A.H. (1941), Fiscal Policy and Business Cycles, George Allen and Unwin Ltd, London

Hansen A.H. (1953), A Guide to Keynes, McGraw-Hill, New York

Hansen G.D. (1985), Indivisible Labor and the Business Cycle, „Journal of Monetary Economics”, vol. 16 (3)

Hansen G.D., R. Wright (1992), The Labor Market in Real Business Cycle Theory, „Quarterly Review" vol. 16, no. 2, Federal Reserve Bank of Minneapolis

Hansen N.L. (1999), Cyclicality of the Danish government budget, [w:] Indicators of Structural Budget Balances, Banca D'Italia

Harding D., Pagan A. (1999), Dissecting the Cycle, Melbourne Institute Working Paper, no. 13

Hardt Ł. (2012), Problem realistyczności założeń w teorii ekonomii, „Ekonomista”, nr 1

Hastings W.K. (1970), Monte Carlo Sampling Methods Using Markov Chains and Their Applications, „Biometrika”, vol. 57, no. 1

Hagemejer J., T. Jędrzejowicz, Z. Żółkiewski (2011), Fiscal tightening after the crisis. A scenario analysis for Poland, „Bank i Kredyt”, nr 3

Heijdra B., J.E. Ligthart (1997), Keynesian Mulitpliers, Direct, Crowding Out, and the Optimal Provision of Public Goods, „Journal of Macroeconomics”, Fall, vol. 19/4

Heitger B., (2002), The Impact of Taxation on Unemployment in OECD Countries, „Cato Journal”, vol. 22 , no. 2

Hemming R., M. Kell, S. Mahfouz (2002), The effectiveness of Fiscal Policy in Stimulating Economic Activity - A Review of the Literature, IMF Working Paper, no. 208

Heppke-Falk K.H., J. Tenhofen, G.B. Wolff (2006), The macroeconomic effects of exogenous fiscal policy shocks in Germany: a disaggregated SVAR analysis, Deutsche Bundesbank, Discussion Paper, no. 41

Hicks J.R. (1937), Mr Keynes and the Classics; A Sutgested Interpretation, „Econometrica”, vol. 5

Ho T.W. (2001), Government spending and private consumption: a panel cointegration Analysis, „International Review of Economics and Finance”, no. 10

Hodrick R.J., E. Prescott (1980), Post-war U.S. Business Cycle: An Empirical Investigation, Working Paper, Carnegie-Mellon University

Hood C.C., J.D. Ashley, D.F. Findley (2000), An Empirical Evaluation of the Performance of TRAMO/SEATS on Simulated Series, Proceedings of the American Statistical Association, Business and Economic Statistics Section, American Statistical Association: Alexandria, VA

Hotz V.J., F.E. Kydland, G.L. Sedlacek (1988), Interetmporal Preferences and Labour Supply, „Econometrica”, vol. 56

Hubbard R.G., K.L. Judd (1986), Liquidity Constraints, Fiscal Policy, and Consumption, „Brookings Papers on Economic Activity", no. 1

Hulten C., R. Schwab (1993), Public capital formation and the Growth of Regional Manufacturing Industries, ,National Tax Journal”, vol. 46

Ismail N.A. (2010), Does government spending crowd out private consumption in Malaysia, „Journal Kemanusiaan”, no. 16

Jarmołowicz W., M. Knapińska (2011), Funkcjonowanie polskiego i unijnego rynku pracy w warunkach zmian koniunkturalnych, [w:] W. Jarmołowicz (red.), Rynek pracy a koniunktura gospodarcza, Wydawnictwo Passat, Poznań

Jarmołowicz W., B. Woźniak-Jęchorek (2011), Rynek pracy, [w:] W. Jarmołowicz, K. Szarzec (red.), Liberalne przestanki polskiej transformacji gospodarczej, PWE, Warszawa 
Jarociński M. (1997), Jednosektorowy model realnego cyklu koniunkturalnego na przyktadzie Niemiec, „Gospodarka Narodowa”, nr 9

Jędrzejowicz T., M. Kitala, A. Wronka (2008), Polityka fiskalna w kraju należącym do strefy euro - wnioski dla Polski, [w:] Raport na temat pelnego uczestnictwa Rzeczypospolitej Polskiej w trzecim etapie Unii Gospodarczej i Walutowej. Projekty badawcze. Cześć III, NBP, Warszawa

Johnson D.S., J. Parker, N. Souleles (2004), Household Expenditure and the Income Tax Rebates of 2001, NBER Working Paper, no. 10784

Józefiak C., P. Krajewski, M. Mackiewicz (2005), Deficyt budżetowy. Przyczyny i metody ograniczenia, PWE, Warszawa

Kamps Ch. (2004), The dynamic macroeconomic effects of public capital: theory and evidence for OECD countries, Springer, Berlin

Karras G. (1994), Government Spending and Private Consumption: Some International Evidence, „Journal of Money, Credit and Banking”, vol. 26

Kashyap A.K. (1995), Sticky Prices: New Evidence from Retail Catalogues, „Quarterly Journal of Economics", vol. 110

Kaufman D., Kraay, A., Mastruzzi M. (2005), Governance Matters IV: Governance Indicators for 1996-2004, Policy Research Working Paper, no. 3106, World Bank, Washington D.C.

Keynes J.M. (1936), The General Theory of Employment, Interest and Money, Macmillan, London (wydanie polskie: Ogólna teoria zatrudnienia, procentu i pieniądza, PWN, Warszawa 1985)

King R.G., S.T. Rebelo (2000), Resuscitating Real Business Cycles, NBER Working Paper, no. 7534

King R.G., M. Watson (1996), Money, Prices, Interest Rates and the Business Cycle, „Review of Economics and Statistics", vol. 78

Klein L.R. (1968), The Keynesian Revoluton, Macmillan, New York

Kolasa M. (2008), Structural heterogeneity or asymmetric shocks? Poland and the euro area through the lens of a two-country DSGE model, NBP, Departament Komunikacji Społecznej, Warszawa

Kollmann R. (2001), The exchange rate in a dynamic-optimizing business cycle model with nominal rigidities: a quantitative investigation, „Journal of International Economics”, vol. 55

Koloch, G. (2008), Stylizowany model DSGE matej gospodarki otwartej w niesymetrycznej unii walutowej - wnioski dla Polski, [w:] Raport na temat petnego uczestnictwa Rzeczypospolitej Polskiej w trzecim etapie Unii Gospodarczej i Walutowej. Projekty badawcze. Cześć VIII, NBP, Warszawa

Konopczak K. (2009), Analiza zbieżności cyklu koniunkturalnego gospodarki polskiej ze strefa euro na tle krajów Europy Środkowo-Wschodniej oraz państw członkowskich strefy, [w:] Raport na temat petnego uczestnictwa Rzeczypospolitej Polskiej w trzecim etapie Unii Gospodarczej $i$ Walutowej. Projekty badawcze. Część III, NBP, Warszawa

Kosterna U. (1995), Deficyt budżetu państwa i jego skutki ekonomiczne, PWN, Warszawa

Krajewski P. (2004), The Importance of The Budget Deficit Decomposition into a Structural and a Cyclical Component, „Comparative Economic Research”, no 1/2

Krajewski P. (2005), Wpływ koniunktury na ksztaltowanie się dochodów budżetowych z podatków od dochodów osobistych, „Ekonomista”, nr 1

Krajewski P. (2011), Podażowe efekty polityki fiskalnej w świetle modelu realnego cyklu koniunkturalnego $i$ wnioski dla gospodarki polskiej, „Ekonomista”, $\mathrm{nr} 4$

Krajewski P., M. Mackiewicz (2006), Dlugookresowy wplyw polityki fiskalnej na ksztaltowanie sie zatrudnienia - analiza panelowa, „Gospodarka w Praktyce i Teorii”, nr 2

Krajewski P., M. Mackiewicz (2007), Dlugookresowy wplyw polityki fiskalnej na stope inwestycji, „Ekonomista”, $\mathrm{nr} 2$

Krawczyk M. (2007), O neutralności dlugu publicznego. Wokót ricardiańskiego teorematu ekwiwalentności - R. Barro. J Tobin i inni, Szkoła Główna Handlowa, Warszawa

Krawczyk M. (2009), Deficyt budżetu państwa i aktywność gospodarcza, „Ekonomista”, nr 5 
Kropiwnicki J.(1976), Teoria automatycznych stabilizatorów koniunktury, PWN, WarszawaKrugman P. (2009), How Did Economists Get It So Wrong?, „The New York Times”, 6 September Krzak M. (2012), Kontrowersje wokót antycyklicznej polityki fiskalnej a niedawny kryzys globalny, Wydawnictwo Elipsa, Warszawa

Kuchta Z. (2012), Wplyw utraty autonomicznej polityki monetarnej na absorpcje zaburzeń egzogenicznych, [w:] P. Krajewski (red.), Gospodarka Polski w perspektywie wstapienia do strefy euro. Ujęcie ilościowe, PWE, Warszawa

Kuchta Z., K. Piłat (2010), Zastosowanie modelu realnego cyklu koniunkturalnego Hansena dla gospodarki Polski, „Gospodarka Narodowa” nr 11-12

Kwaśnicki W. (2012), O matematyzacji ekonomii, „Ekonomista”, nr 3

Kydland F.E, E.C. Prescott (1977), Rules Rather Than Discretion: The Inconsistency of Optimal Plans, ,Journal of Political Economy”, vol. 85

Kydland F.E., E.C. Prescott (1982), Time to Build and Aggregate Fluctuations, „Econometrica”, vol. 50, issue 6

Kydland F.E., E.C Prescott. (1996), The Computational Experiment: An Econometric Tool, „The Journal of Economic Perspectives", vol. 10, no. 1

Lane P. (2003), The Cyclical Behavior of Fiscal Policy: Evidence from the OECD, „Journal of Public Economics", vol. 87

Langenus G. (1999), The NBB's work on structural or cyclically-adjusted fiscal indicators, [w:] Indicators of Structural Budget Balances, Banca D'Italia

Leibfritz W., J. Thornton, A. Bibbee (1997), Taxation and Economic Performance, OECD Economics Department Working Papers, no. 176

Levine P., J. Pearlman, B. Yang (2007), The Credibility Problem Revisited: Thirty Years on from Kydland and Prescott, University of Surrey, Discussion Papers in Economics, no. 18

Levin A., V. Wieland, J.C. Williams (2003), The performance of forecast-based monetary policy rules under model uncertainty, „The American Economic Review”, vol. 93(3)

Levy D., M. Bergen, S. Dutta, R. Venable (1997), The Magnitude of Menu Costs: Direct Evidence from Large U.S.. Supermarket Chains, „Quarterly Journal of Economics”, no. 3

Linnemann L., A. Schabert (2003), Fiscal Policy In the New Neoclassical Synthesis, „Journal of Money, Credit and Banking", vol. 35

Linnemann L., A. Schabert (2005), Productive Government Expenditure in Monetary Business Cycle Models, Tinbergen Institute Discussion Paper, no. 053/2

Ljungqvist L., T.J. Sargent (2004), Recursive macroeconomic theory, MIT Press, Cambridge Mass.

Lubiński M. (2002), Analiza koniunktury i badanie rynków, Wydawnictwo Elipsa, Warszawa

Lubiński M. (2010), Polityka fiskalna wobec kryzysu finansowego. Próba oceny, „Gospodarka Narodowa", nr 9

Lubiński M. (2011), Przyszłość Paktu stabilności i wzrostu, „Gospodarka Narodowa”, nr 1-2

Lucas R. (1976), Econometric Policy Evaluation: A Critique, „Carnegie-Rochester Conference Series on Public Policy", no. 1

Ludvigson S. (1996), The Macroeconomic Effects of Government Debt in Stochastic Growth Model, „Journal of Monetary Economics”, vol. 38

Łaski K., J. Osiatyński, J. Zięba (2010), Mnożnik wydatków państwowych i szacunki jego wielkości dla Polski, NBP, Materiały i Studia, zeszyt nr 246

Maciejowska K., P. Ziernik (2005), Modele przełacznikowe Markowa w analizach cykli koniunkturalnych przy wykorzystaniu wskaźników koniunktury, „Zeszyty Koniunktury w Gospodarce Polskiej”, nr 21

Mackiewicz M. (2010), Stabilizacyjna polityka fiskalna w krajach OECD, PWE, Warszawa 2010

Małecki-Tepicht S. (2012), Instrukcja obstugi maszynki do mięsa nie jest książka kucharska, „Ekonomista”, nr 3 
Mankiw N.G. (1985), Small Menu Costs and Large Business Cycles: A Macroeconomic Model of Monopoly, „Quarterly Journal of Economics”, May

Mankiw N.G. (2000), The Savers-Spenders Theory of Fiscal Policy, „American Economic Review”, vol. 90 , no. 2

Mankiw N.G. (2006), The Macroeconomist as Scientist and Engineer, „Journal of Economic Perspectives", vol. 20 (4).

Mankiw N.G., D. Romer (eds.), (1991), New Keynesian Economics, MIT Press, Cambridge Mass.

McCallum B., E. Nelson (1999), Nominal Income Targeting in an Open-Economy Optimizing Model, ,Journal of Monetary Economics”, vol. 43.

McCandless G. (2008), The ABCs of RBCs. An Introduction to Dynamic Macroeconomic Models, Harvard University Press, Cambridge Mass.

McCoy D. (1997), How useful is Structural VAR Analysis for Irish Economics?, Central Bank of Ireland, Technical Paper, April

McGrattan E.R. (1994), The Macroeconomic Effects of Distortionary Taxation, „Journal of Monetary Economics", vol. 33

McGrattan E.R., E.C. Prescott (2012), The Labor Productivity Puzzle, Federal Reserve Bank of Minneapolis, Working Paper, no. 694

McMorrow K., W. Roger (2001), Potential Output: Measurement Methods, 'New' Economy Influences and Scenarios for 2001-2010 - A comparison of the EU15 and the US, European Communities, Economic Papers, no. 150

Meier A., G.J. Muller(2006), Fleshing Out the Monetary Transmission Mechanism: Output Composition and the Role of Financial Frictions, ,Journal of Money, Credit, and Banking”, vol. 38 (8)

Metropolis N., A.W. Rosenbluth, M..N. Rosenbluth, A.H. Teller, E. Teller (1953), Equation of State Calculations by Fast Computing Machines, „The Journal of Chemical Physics”, vol. 21, no. 6

Milo W. (2000), O cyklach koniunkturalnych, [w:] A. Zeliaś (red.), Przestrzenno-czasowe modelowanie i prognozowanie zjawisk gospodarczych, Wydawnictwo Akademii Ekonomicznej w Krakowie, Kraków

Milo W. (2005), Analiza modeli cykli gospodarczych K. Wicksella, R. Frischa, N. Kaldora, Prace i Materiały Wydziału Zarządzania Uniwersytetu Gdańskiego, nr 1

Milo W., M. Malaczewski, G. Szafrański, M. Ulrichs, Z. Wośko (2010), Stabilność rynków kapitatów a wzrost gospodarczy, Wyd. Nauk. PWN, Warszawa

Milo W., G. Szafrański (2005), Uwagi na temat kapitału ludzkiego, [w:] A. Zeliaś (red.), Przestrzenno-czasowe modelowanie i prognozowanie zjawisk gospodarczych, Wydawnictwo Akademii Ekonomicznej w Krakowie, Kraków

Milo W., G. Szafrański, Z. Wośko, M. Malaczewski (2006), Rynki inwestycyjne a wzrost gospodar$c z y$, Wydawnictwo Uniwersytetu Łódzkiego, Łódź

Milo W., Z. Wesoły, U. Cieśluk (1999). Bezrobocie, aktywność kapitałowa, ceny a wzrost gospodarczy Polski, Wydawnictwo Uniwersytetu Łódzkiego, Łódź

Mitra P. (2006), Post-Crisis Recovery: When Does Increased Fiscal Discipline Work?, IMF Working Paper, no. 219

Momigliano S. (1999), Introduction, [w:] Indicators of structural budget balances, Banca D'Italia

Momigliano S., A. Staderini (1999), A New Method of Assessing the Structural Budget Balance: Results for the Years 1995-2000, [w:] Indicators of Structural Budget Balances, Banca D'Italia

Monacelli T., R. Perotti (2008), Fiscal Policy, Wealth Effects and Markups, NBER Working Paper, no. 14584

Morris R., H. Ongena, L. Schuknecht (2006), The Reform and Implementation of the Stability and Growth Pact, European Central Bank, Occasional Paper Series, no. 47

Mortensen D.T., C.A. Pissarides (1999), New Developments in Models of Search in the Labor Market, [w:] O. Ashenfelter, D. Card (eds.), Handbook of Labor Economics, Elsevier, NorthHolland, Amsterdam. 
Mountford A., H. Uhlig (2002), What are the Effects of Fiscal Policy Shocks?, CEPR, Discussion Paper, no. 3338

Moździerz A. (2009), Nierównowaga finansów publicznych, PWE, Warszawa

Moździerz A. (2011), O potrzebie wzmocnienia nadzoru fiskalnego w Unii Europejskiej,[w:] A. Moździerz i K. Surówka (red.), O nowy model działalności regulacyjnej państwa w sferze finansów. Księga Jubileuszowa prof. zw. dr. hab. Stanisława Owsiaka, PWE, Warszawa

Murchison S., J. Robbins (2002), Fiscal Policy and the Business Cycle: A New Approach to Identifying the Interaction, [w:] The Impact of Fiscal Policy, Banca D'Italia

Musgrave R.A., P.B. Musgrave (1989), Public Finance in Theory and Practice, McGraw Hill International Editions, New York

Myles G.D. (2009), Economic growth and the role of taxation, OECD, Economic Department WP, no. 714, Paris

Myrdal G. (1939), Polityka fiskalna w cyklu koniunkturalnym, „American Economic Review”, thumaczenie w: „Teoria i polityka stabilizacji koniunktury. Wybór tekstów”, PWE, Warszawa 1975

Nelson C.R., C.I. Plosser (1982), Trends and Random Walks in Macroeconomics Time Series: Some Evidence and Implications, „Journal of Monetary Economics”, September

Nickell S. (1997), Unemployment and Labor Market Rigidities: Europe versus North America, „Journal of Economic Perspectives”, vol. 11

Nickell S., Layard R., (1997), Labour Market Institutions and Economic Performance, Discussion Paper Series, no 23, Centre for Economic Research

Ohanian, L. (1997), The Macroeconomic Effects of War Finance in the United States: World War II and the Korean War, „American Economic Review”, vol. 87

OECD (2000), Links Between Economy and Growth - Cross Country Evidence, „OECD Economic Outlook", vol. 68

Okubo M. (2003), Intratemporal Substitution between Private and Government Consumption: The Case of Japan, „Economics Letters”, vol. 79

Orłowski W. (2008), Kto zyska na euro?, „Monitor Unii Europejskiej”, nr 1

Osiewalski J. (1991), Bayesowska estymacja i predykcja dla jednorównaniowych modeli ekonometrycznych, Akademia Ekonomiczna w Krakowie, Kraków

Osiewalski J. (2001), Ekonometria bayesowska w zastosowaniach, Wydawnictwo Akademii Ekonomicznej w Krakowie, Kraków

Owsiak S. (2002), Finanse Publiczne. Teoria i praktyka, Wyd. Nauk. PWN, Warszawa

Owsiak S. (2011a), Stabilność systemu zasilania finansowego a nowatorskie zarzadzanie podmiotami publicznymi w warunkach kryzysu, [w:] S. Owsiak (red.), Nowe zarzadzanie finansami publicznymi w warunkach kryzysu, PWE, Warszawa

Owsiak S. (2011b), Wplyw kryzysu finansowego na wydatki publiczne, [w:] A. Alińska, B. Pietrzak (red.), Finanse publiczne a kryzys ekonomiczny, Wydawnictwo CeDeWu, Warszawa

Owsiak S. (2012), Społeczny wymiar kryzysu - lekcja dla przyszłości, „Biuletyn PTE”, nr 2(56)

Owsiak S., M. Kosek-Wojnar, K. Surówka (1993), Równowaga budżetowa. Deficyt budżetowy. Dług publiczny, PWN, Warszawa

Panek E., P. Kliber (2007), Optimal Tax Progression, „Argumenta Oeconomica”, no. 1-2

Pappa E. (2004), New Keynesian or RBC Transmission? The Effects of Fiscal Policy in Labor Markets, Università Bocconi Working Paper, no. 293

Pedregal D.J., P.C. Young (2001), Some Comments on the Use and Abuse of Hodrick-Prescott Filter, „Review on Economic Cycle”, vol. 2

Perotti R. (2002), Estimating the Effects of Fiscal Policy in OECD Countries, ISOM, Frankfurt

Perotti R. (2007), In Search of the Transmission Mechanism of Fiscal Policy, NBER Working Paper, no. 13143

Perry G. (2003), Can Fiscal Rules Help Reduce Macroeconomic Volatility in the Latin America and the Caribbean Region?, Policy Research Working Paper, no. 3080, World Bank, Washington D.C. 
Phelps E.S., Taylor J.B. (1977), Stabilizing Powers of Monetary Policy under Rational Expectations, „Journal of Political Economy”, February

Pietrzak B., Z. Polański, B. Woźniak (red.) (2003), System finansowy w Polsce, Wyd. Nauk. PWN, Warszawa

Pipień M. (2006), Wnioskowanie bayesowskie w ekonometrii finansowej, Wydawnictwo Akademii Ekonomicznej w Krakowie, Kraków

Pissarides C.A. (1996), Are Employment Tax Cuts the Answer to Europe's Unemployment Problem, Centre for Economic Performance

Plosser Ch.I. (1989), Understanding Real Business Cycles, „Journal of Economic Perspectives”, vol. 3 (3)

Rabanal P., J.F. Rubio-Ramirez (2005), Comparing New Keynesian Models of the Business Cycle. A Bayesian Approach, „Journal of Monetary Economics”, vol. 52

Ramey V.A. (2008), Identifying Government Spending Shocks: Its All in the Timing, Department of Econoomics, UC San Diego

Ratto M., W. Roeger, J. in't Veld (2008), QUEST III: An estimated DSGE model of the euro area with fiscal and monetary policy, „European Economy, Economic Paper, no. 353

Ravn M., S. Schmitt-Grohe, M. Uribe (2006), Deep Habits, „Review of Economic Studies”, vol. 73

Rebelo S. (2005), Real Business Cycle Models: Past, Present, and Future Issue, „The Scandinavian Journal of Economics", vol. 107, issue 2

Roger W., J. in't Veld (1997), QUEST II:A Multi Country Business Cycle and Growth Model, European Commission Economic Papers, no. 123

Roger W., H. Ongena (1999), The Commission Services 'Cyclical Adjustment Method, [w:] Indicators of structural budget balances, Banca D'Italia

Romer Ch., J. Bernstein (2009), The Job Impact of the American Recovery and Reinvestment Plan, http://www.economy.com

Romer Ch., D. Romer, (2007), The Macroeconoimc Effects of Tax Change: Estimates Based in a New Measure of Fiscal Shocks, Economics Working Papers, Berckley University

Romer D., (2000), Makroekonomia dla zaawansowanych, Wyd. Nauk. PWN, Warszawa

Rotemberg J., M. Woodford (1991), Markups and the Business Cycle, [w:] O.J. Blanchard i S. Fischer (eds.), „NBER Macroeconomics Annual”, MIT Press, Cambridge Mass.

Rotemberg J., M. Woodford (1999), The Cyclical Behavior of Prices and Costs", [w:] J.B. Taylor i M. Woodford (eds.), Handbook of Macroeconomics, North-Holland, Amsterdam

Ruge-Murcia F.J. (2007), Methods to estimate dynamic stochastic general equilibrium models, „Journal of Economic Dynamics and Control”, vol. 31

Rzońca A. (2004), Niekeynesowskie skutki zacieśnienia polityki fiskalnej, „Bank i Kredyt”, nr 10, nr $11-12$

Rzońca A. (2007), Czy Keynes się pomylit, Wyd. Nauk. Scholar, Warszawa

Rzońca, A., P. Ciżkowicz (2005), Non-Keynesian effects of fiscal contraction in new member states, European Central Bank Working Paper, no. 519

Samuelson P.A. (1948), Economics, McGraw-Hill, New York

Samuelson P.A., W.D. Nordhaus (1995), Ekonomia, PWN, Warszawa

Sargent T.J., N. Wallace (1976), Rational Expectations and the Theory of Economic Policy, „Journal of Monetary Economics", April

Scharnagl M., Todter K. (2004), How effective are automatic stabilizers. Theory and empirical results for Germany and other OECD countries, Deutsche Bundesbank, Discussion Paper, no 21

Schorfheide F. (2000), Loss Function-Based Evaluation of DSGE Models, „Journal of Applied Econometrics", vol.15

Sims Ch. (1980), Macroeconomics and reality, „Econometrica”, vol. 48 (1)

Siwińska-Gorzelak J. (2010), Niestabilność wydatków publicznych a dtugookresowy wzrost gospodarczy, „Ekonomista”, nr 2 
Skrzypczyński P. (2006), Analiza synchronizacji cykli koniunkturalnych w strefie euro, NBP, Materiały i Studia, zeszyt nr 210

Skrzypczyński P. (2010), Metody spektralne w analizie cyklu koniunkturalnego gospodarki polskiej, NBP, Materiały i Studia, zeszyt $\mathrm{nr} 252$

Sławiński A. (2008), Znaczenie czynników ryzyka towarzyszacych wchodzeniu Polski do ERM2 i do strefy euro, „Ekonomista”, nr 1

Smets F., R. Wouters (2003), An Estimated Dynamic Stochastic General Equilibrium Model of the Euro Area, „Journal of European Economic Association”, vol. 1, no. 5

Smets F., R. Wouters (2004), Forecasting with a Bayesian DSGE Model: An Application to the Euro Area, „Journal of Common Market Studies”, vol. 42, no. 4

Smets F., R. Wouters (2007), Shocks and Frictions in US Business Cycles: A Bayesian DSGE Approach, „American Economic Review”, vol. 97 (3)

Snowdon B., H. Vane, P. Wynarczyk (1998), Wspótczesne nurty teorii makroekonomii, PWN, Warszawa

Stadler G.W., (1994), Real Business Cycle, ,Journal of Economics Literature”, vol. 32

Stiglitz J., (1988), Economics of the Public Sector, W. W. Norton \& Co., New York, London

Summers L.H. (1986), Some skeptical observations on real business cycle theory, „Federal Reserve Bank of Minneapolis Quarterly Review", vol. 10, no. 4

Sztaudynger J. J. (2005), Wzrost gospodarczy a kapitat społeczny, prywatyzacja i inflacja, Wyd. Nauk. PWN, Warszawa

Talvi E., C. Vegh, (2005), Tax Base Variability and Procyclicality of Fiscal Policy, „Journal of Development Economics", vol. 78

Taylor J.B. (1993), Discretion versus Policy Rules in Practice, „Carnegie-Rochester Conference Series on Public Policy", vol. 39

Taylor J.B. (1979), Staggered Wage Setting in a Macro Model, „American Economic Review”, vol. 69 , no. 2

Taylor J.B. (1980), Aggregate Dynamics and Staggered Contracts, „,ournal of Political Economy”, February

Taylor J.B. (1999), Staggered Price and Wage Setting in Macroeconomics, [w:] J.B. Taylor, M. Woodford (eds.), Handbook of Macroeconomics, Elsevier, New York

Tanzi V., H. Zee (1998), Taxation and the Household Saving Rate: Evidence from OECD Countries, IMF Working Paper, no. 36

Tanzi V., H. Zee (2000), Tax Policy for Emerging Markets: Developing Countries, IMF Working Paper, no. 35

The Royal Swedish Academy of Sciences (2004), Finn Kydland and Edward Precott's Contribution to Dynamic Macroeconomics, Information Department of The Royal Swedish Academy of Sciences, Stockholm

Tobin J. (1978), Comment from Academic Scribbler, „Journal of Monetary Economics”, vol. 4, no. 3

Tokarski T. (2001), Wzrost gospodarczy a zatrudnienie w wybranych krajach OECD, „Gospodarka Narodowa", nr 7-8

Totzek A., R. Winkler (2010), Fiscal stimulus in a model with endogenous firm entry, Economics Working Paper Christian-Albrechts-Universität Kiel, Department of Economics, no. 5

Turnovsky S.J. (2000), Methods of Macroeconomic Dynamics, MIT Press, Cambridge

Tversky A., D. Kahneman, (1974), Judgment under Uncertainty: Heuristics and Biases, „Science”, vol. 185

Uhlig H. (2010), Some Fiscal Calculus, „American Economic Review”, vol. 100 (2)

Url T. (1997), How Serious is the Pact on Stability and Growth?, Austrian Institute of Economic Research, Vienna

Van Brusselen P. (2010), Fiscal Stabilisation Plans and the Outlook for the World Economy, Banca d'Italia, 12th Public Finance Workshop "Fiscal Policy: Lessons from the Crisis", Perugia 
Van den Noord P. (2000), The Size and Role of Automatic Fiscal Stabilizers in the 1990s and beyond, OECD, Economic Department Working Papers, no. 230

Van den Noord P., Ch. Heady (2002), Tax Design, Economic Efficiency and Growth, [w:] The Impact of Fiscal Policy, Banca d'Italia

Welfe W. (2007), Knowledge capital and total factor productivity, $63^{\text {rd }}$ International Atlantic Economic Conference, Madrid

Wieland V., T. Cwik, G.J. Müller, S. Schmidt, M. Wolters (2012), A New Comparative Approach to Macroeconomic Modeling and Policy Analysis, Center for Financial Studies, Working Paper, no. 3

Wilkin J. (2012), Czy wspótczesna ekonomia jest instrukcją obstugi mechanizmu gospodarczego?, „Ekonomista”, nr 3

Wnorowski H. (2010), Wplyw podatków na wzrost gospodarczy i konkurencyjność w ujęciu instytucjonalnym, „Gospodarka Narodowa”, nr 4

Wojtyna A. (2000), Ewolucja keynesizmu a główny nurt ekonomii, Wyd. Nauk. PWN, Warszawa

Wojtyna A. (2003), Polityka makroekonomiczna w cyklu koniunkturalnym - nowe nurty w teorii, „Gospodarka Narodowa”, nr 5-6

Wojtyna A. (2008), Wspótczesna ekonomia - kontynuacja czy poszukiwanie nowego paradygmatu?, „Ekonomista”, nr 1

Wojtyna A. (2010), Gospodarki wschodzace w obliczu kryzysu finansowego: duża odporność czy podatność?, „Gospodarka Narodowa”, nr 9

Wojtyna A. (2012), Standardowe i niestandardowe działania antykryzysowe $w$ gospodarkach wschodzacych, [w:] A. Wojtyna (red.), Efekty dziatań antykryzysowych w krajach na średnim poziomie rozwoju, PWE, Warszawa

Woo J. (2005), The Behavior of Fiscal Policy: Cyclicality and Discretionary Fiscal Decisions, Fiscal Policy Workshop at the University of Oslo, January

Woodford M. (1996), Control of the Public Debt: A Requirement for Price Stability, NBER Working Paper, no. 5684

Woodford M. (2003), Interest \& Prices, Princeton University Press, Princeton

Woodford M. (2011), Simple Analytics of the Government Expenditure Multiplier, „American Economic Journal: Macroeconomics", vol. 3 (1)

Wośko Z. (2009), Czy filtry liniowe sa przydatnym narzędziem badania koniunktury? Analiza spektralna na przykładzie ankietowych wskaźników koniunktury, [w:] J. Czech-Rogosz, R. Żelazny (red.), Koniunktura gospodarcza. Od bańki internetowej do kryzysu Subprime, C.H. Beck, Warszawa

Wyplosz (2006), European Monetary Union: The Dark Sides of a Major Success, „Economic Policy", April

Yasuharu I. (2009), Fiscal Policy in an Estimated DSGE Model of the Japanese Economy: Do NonRicardian Households Explain All?, ESRI Discussion Paper Series, no. 216

Zubairy S. (2010), On Fiscal Multipliers: Estimates from a Medium Scale DSGE Model, Bank of Canada, Working Paper, no. 30 



\section{Spis symboli}

\begin{tabular}{|c|c|c|c|}
\hline $\mathrm{A}, \alpha$ & alfa & $\begin{array}{l}\alpha_{w} \\
\alpha^{B}\end{array}$ & $\begin{array}{l}\text { - prawdopodobieństwo niewygaśnięcia kontraktu płacowego w danym } \\
\text { okresie } \\
\text { - udział wydatków bieżących w wydatkach publicznych }\end{array}$ \\
\hline $\mathrm{B}, \beta$ & beta & $\begin{array}{l}\beta \\
\beta_{j} \\
\beta_{\pi}\end{array}$ & $\begin{array}{l}\text { - subiektywny czynnik dyskontowy } \\
\text { - krótkookresowa elastyczność wydatków publicznych kategorii } j \\
\text { względem PKB } \\
\text { - parametr w nowokeynesistowskiej krzywej Phillipsa }\end{array}$ \\
\hline$\Gamma, \gamma$ & gamma & $\begin{array}{l}\gamma_{P} \\
\gamma_{w} \\
\Gamma\end{array}$ & $\begin{array}{l}\text { - krańcowa stopa substytucji pomiędzy konsumpcją prywatną } \\
\text { i publiczną } \\
\text { - stopień indeksacji cen } \\
\text { - stopień indeksacji płac } \\
\text { - funkcja określająca addytywny wpływ polityki fiskalnej na } \\
\text { użyteczność }\end{array}$ \\
\hline$\Delta, \delta$ & delta & $\delta$ & - stopa deprecjacji \\
\hline $\mathrm{E}, \varepsilon$ & epsilon & $\begin{array}{l}\varepsilon_{t} \\
\varepsilon_{i}\end{array}$ & $\begin{array}{l}\text { - składnik losowy / szok } \\
\text { - krótkookresowa elastyczność dochodów publicznych kategorii } \\
i \text { względem PKB }\end{array}$ \\
\hline$Z, \zeta$ & dzeta & $\zeta_{t}$ & - składnik losowy \\
\hline $\mathrm{H}, \eta$ & eta & $\begin{array}{l}\eta \\
\eta_{c} \\
\eta_{l} \\
\eta_{w}\end{array}$ & $\begin{array}{l}\text { - elastyczność substytucji dóbr pośrednich } \\
\text { - elastyczności substytucji dóbr konsumpcyjnych składających się na } \\
\text { koszyk dóbr } \\
\text { - elastyczność substytucji pracy dostarczanej przez poszczególne } \\
\text { gospodarstwa domowe } \\
\text { - elastyczność substytucji pomiędzy zawodami }\end{array}$ \\
\hline$\Theta, \theta$ & theta & $\begin{array}{l}\theta, \theta_{k} \\
\theta_{k G} \\
\theta_{l}\end{array}$ & $\begin{array}{l}\text { - elastyczność produkcji względem kapitału } \\
\text { - elastyczność produkcji względem kapitału publicznego } \\
\text { - elastyczność produkcji względem pracy }\end{array}$ \\
\hline $\mathrm{K}, \kappa$ & kappa & $\begin{array}{l}\kappa_{g}, \kappa_{\tau} \\
\kappa_{y}\end{array}$ & $\begin{array}{l}\text { - parametry określające antycykliczność polityki fiskalnej } \\
\text { - parametr w nowokeynesistowskiej krzywej Phillipsa }\end{array}$ \\
\hline$\Lambda, \lambda$ & lambda & $\begin{array}{l}\lambda \\
\lambda_{p, t} \\
\lambda_{w, t} \\
\Lambda_{t}\end{array}$ & $\begin{array}{l}\text { - udział gospodarstw niericardiańskich } \\
\text { - narzut na ceny } \\
\text { - narzut na wynagrodzenia } \\
\text { - mnożnik Lagrange'a }\end{array}$ \\
\hline
\end{tabular}




\begin{tabular}{|c|c|c|c|}
\hline $\mathrm{M}, \mu$ & $\mathrm{mi}$ & $\begin{array}{l}\mu_{t} \\
\mu_{m}\end{array}$ & $\begin{array}{l}\text { - krańcowy produkt dóbr i usług dostarczanych przez państwo } \\
\text { - stopa wzrostu podaży pieniądza }\end{array}$ \\
\hline$\Xi, \xi$ & ksi & $\begin{array}{l}\xi_{t} \\
\xi_{e m p} \\
\xi_{p} \\
\xi_{w}\end{array}$ & $\begin{array}{l}\text { - składnik losowy } \\
\text { - parametr określający dostosowania zatrudnienia } \\
\text { - prawdopodobieństwo, że w danym okresie przedsiębiorstwo nie } \\
\text { będzie optymalizowało poziom cen } \\
\text { - prawdopodobieństwo, że w danym okresie gospodarstwo domowe nie } \\
\text { będzie optymalizowało poziomu płac }\end{array}$ \\
\hline$\Pi, \pi$ & pi & $\begin{array}{l}\pi_{t} \\
\pi^{*} \\
\Pi_{t}(i)\end{array}$ & $\begin{array}{l}\text { - inflacja / zyski przedsiębiorstw } \\
\text { - poziom celu inflacyjnego } \\
\text { - zysk przedsiębiorstwa produkującego dobro pośrednie } i\end{array}$ \\
\hline $\mathrm{P}, \rho$ & rho & $\begin{array}{l}\rho \\
\rho_{t} \\
\rho_{t}^{\pi} \\
\rho_{r}\end{array}$ & $\begin{array}{l}\text { - współczynnik autoregresji zmiennej } \\
\text { - krańcowy produkt kapitału } \\
\text { - czynnik dyskontujący w ramach dyskontowania zysków } \\
\text { - parametr określający stopień wygładzenia stopy procentowej }\end{array}$ \\
\hline$\Sigma, \sigma$ & sigma & $\begin{array}{l}\sigma \\
\sigma_{c} \\
\sigma_{l} \\
\sigma_{u}\end{array}$ & $\begin{array}{l}\text { - odchylenie standardowe składnika losowego } \\
\text { - odwrotność międzyokresowej elastyczności substytucji konsumpcji } \\
\text { - odwrotność międzyokresowej elastyczności substytucji czasu } \\
\text { wolnego } \\
\text { - współczynnik względnej niechęci do ryzyka w funkcji użyteczności }\end{array}$ \\
\hline $\mathrm{T}, \tau$ & tau & $\begin{array}{l}\tau_{t} \\
\tau_{k, t} \\
\tau_{w, t}\end{array}$ & $\begin{array}{l}\text { - stopa opodatkowania dochodów } \\
\text { - stopa opodatkowania kapitału } \\
\text { - stopa opodatkowania wynagrodzen }\end{array}$ \\
\hline $\mathrm{Y}, \mathrm{v}$ & ypsīlon & $v_{t}$ & - płaca ustalona w kontrakcie w okresie $t$ \\
\hline$\Phi, \varphi$ & phi & $\begin{array}{l}\varphi \\
\varphi_{j} \\
\varphi_{S}\end{array}$ & $\begin{array}{l}\text { - parametr określający wpływ czasu pracy na poziom użyteczności } \\
\text { - udział nakładów inwestycyjnych z okresu t użytych w procesach } \\
\text { inwestycyjnych } j \text { okresów przed ukończeniem } \\
\text { - parametr określający koszty dostosowania inwestycji }\end{array}$ \\
\hline $\mathrm{X}, \chi$ & chi & $\chi$ & $\begin{array}{l}\text { - parametr określający wagę czasu wolnego i konsumpcji w funkcji } \\
\text { użyteczności }\end{array}$ \\
\hline$\Psi, \psi$ & psi & $\begin{array}{l}\psi \\
\psi_{w} \\
\Psi\end{array}$ & $\begin{array}{l}\text { - parametr określający koszty zmiennego stopnia wykorzystania } \\
\text { kapitału } \\
\text { - parametr ukazujący siłę wpływu nierównowagi na rynku pracy na } \\
\text { kontrakty płacowe } \\
\text { - funkcja kosztów związanych z niepełnym lub nadmiernym stopniem } \\
\text { wykorzystania kapitału }\end{array}$ \\
\hline$\Omega, \omega$ & omega & $\begin{array}{l}\Omega_{t} \\
\Omega_{i, t}\end{array}$ & $\begin{array}{l}\text { - poziom majątku gospodarstw domowych } \\
\text { - zyski } i \text {-tej firmy działającej w warunkach konkurencji } \\
\text { monopolistycznej }\end{array}$ \\
\hline
\end{tabular}




\begin{tabular}{|c|c|c|}
\hline $\mathrm{A}, \mathrm{a}$ & $\begin{array}{l}a_{t} \\
a_{v} \\
A \\
A_{t}^{j} \\
A T R_{j}\end{array}$ & $\begin{array}{l}\text { - majątek gospodarstwa domowego w postaci zasobów kapitału i realnych } \\
\text { zasobów pieniądza } \\
\text { - parametr określający siłę przyzwyczajeń konsumpcyjnych } \\
\text { - miara wagi przypisywanej czasowi wolnemu względem konsumpcji } \\
\text { - wypłaty z ubezpieczenia otrzymywane przez j-te gospodarstwo domowe } \\
\text { - przeciętna stopa podatkowa dla j-tego przedziału podatkowego }\end{array}$ \\
\hline $\mathrm{B}, \mathrm{b}$ & $\begin{array}{l}b_{t} \\
b_{t}^{g} \\
B_{t} \\
B_{t}^{j} \\
\\
B B_{t}^{C} \\
B B_{t}^{S}\end{array}$ & $\begin{array}{l}\text { - obligacje w ujęciu realnym posiadane przez gospodarstwa domowe } \\
\text { - obligacje w ujęciu realnym posiadane przez państwo } \\
\text { - obligacje w ujęciu nominalnym posiadane przez gospodarstwa domowe } \\
\text { - ilość jednookresowych obligacji posiadanych przez } j \text {-te gospodarstwo } \\
\text { domowe } \\
\text { - cykliczny komponent salda budżetowego } \\
\text { - strukturalny komponent salda budżetowego }\end{array}$ \\
\hline $\mathrm{C}, \mathrm{c}$ & $\begin{array}{l}c \\
c_{t} \\
c_{t}^{e} \\
c_{i, t} \\
c_{t}^{j} \\
C_{t} \\
C_{t}^{N R} \\
C_{t}^{R} \\
C I T_{t}\end{array}$ & $\begin{array}{l}\text { - krańcowa skłonność do konsumpcji } \\
\text { - konsumpcja } \\
\text { - efektywna konsumpcja } \\
\text { - konsumpcja dobra } i \text { w koszyku dóbr } \\
\text { - konsumpcja j-tego gospodarstwa domowego } \\
\text { - konsumpcja dobra finalnego wytwarzanego na podstawie dóbr pośrednich / } \\
\text { zagregowany indeks konsumpcji } \\
\text { - konsumpcja gospodarstw niericardiańskich } \\
\text { - konsumpcja gospodarstw ricardiańskich } \\
\text { - wpływy z podatku dochodowego od osób prawnych }\end{array}$ \\
\hline $\mathrm{D}, \mathrm{d}$ & $\begin{array}{l}D_{t}^{j} \\
D_{t}^{R}\end{array}$ & $\begin{array}{l}\text { - dywidendy wypłacane } j \text {-temu gospodarstwu domowemu } \\
\text { - dywidenda wypłacana gospodarstwom ricardiańskim }\end{array}$ \\
\hline $\mathrm{E}, \mathrm{e}$ & $\begin{array}{l}e_{t} \\
E_{j, t} \\
E_{j, t}^{C} \\
E_{t}^{G} \\
E_{j, t}^{S}\end{array}$ & $\begin{array}{l}\text { - nadwyżka popytu } \\
\text { - wydatki publiczne kategorii } j \\
\text { - cykliczne wydatki publiczne kategorii } j \\
\text { - wydatki publiczne } \\
\text { - strukturalne wydatki publiczne kategorii } j\end{array}$ \\
\hline $\mathrm{F}, \mathrm{f}$ & $\begin{array}{l}F C \\
F C_{Y}\end{array}$ & $\begin{array}{l}\text { - koszt stały } \\
\text { - parametr dotyczący udziału kosztów stałych w produkcie }\end{array}$ \\
\hline $\mathrm{G}, \mathrm{g}$ & $\begin{array}{l}g_{t} \\
g_{t}^{B} \\
g_{i, t} \\
g_{t}^{N S} \\
g_{t}^{S} \\
g_{y} \\
G_{t} \\
G_{t}^{V A T}\end{array}$ & $\begin{array}{l}\text { - wydatki rządowe } \\
\text { - bieżące wydatki rządowe } \\
\text { - wydatki rządowe na zakup dobra } i \\
\text { - wydatki rądowe niebędące substytutami konsumpcji prywatnej } \\
\text { - wydatki rządowe stanowiące substytut konsumpcji prywatnej } \\
\text { - udział wydatków rządowych w PKB } \\
\text { - wydatki rządowe na zakup dóbr finalnych wytwarzanych na podstawie dóbr } \\
\text { pośrednich } \\
\text { - zakupy rządowe objęte podatkiem VAT }\end{array}$ \\
\hline
\end{tabular}




\begin{tabular}{|c|c|c|}
\hline $\mathrm{H}, \mathrm{h}$ & & $\begin{array}{l}\text { - czas wolny } \\
\text { - nierozdzielny czas wolny } \\
\text { - dostępny zasób czasu ogółem }\end{array}$ \\
\hline $\mathrm{I}, \mathrm{i}$ & $\begin{array}{l}i_{t} \\
i_{t}^{j} \\
i_{t}^{G} \\
i_{t}^{R} \\
I_{t} \\
I T_{t}\end{array}$ & $\begin{array}{l}\text { - inwestycje } \\
\text { - inwestycje } j \text {-tego gospodarstwa domowego } \\
\text { - wydatki inwestycyjne państwa } \\
\text { - inwestycje gospodarstw ricardiańskich } \\
\text { - inwestycje w dobra finalne wytwarzane na podstawie dóbr pośrednich } \\
\text { - wpływy z podatków pośrednich }\end{array}$ \\
\hline $\mathrm{K}, \mathrm{k}$ & $\begin{array}{l}k_{t} \\
k_{t}(i) \\
k_{t}^{G} \\
k_{t}^{j} \\
k_{t}^{R}\end{array}$ & $\begin{array}{l}\text { - kapitał } \\
\text { - kapitał wykorzystywany do produkcji } i \text {-tego dobra pośredniego } \\
\text { - zasób kapitału dostarczanego przez państwo } \\
\text { - kapitał posiadany prze } j \text {-te gospodarstwo domowe } \\
\text { - kapitał posiadany przez gospodarstwa ricardiańskie }\end{array}$ \\
\hline $\mathrm{L}, 1$ & $\begin{array}{l}l_{t} \\
l_{t}^{d} \\
l_{t}(i) \\
l_{t}^{j} \\
l_{j, t} \\
l_{t}^{N R} \\
l_{t}^{R} \\
l_{t}^{s} \\
L_{t} \\
L_{t}(i)\end{array}$ & $\begin{array}{l}\text { - czas pracy / zatrudnienie } \\
\text { - popyt na pracę } \\
\text { - nakład pracy przy produkcji } i \text {-tego dobra pośredniego } \\
\text { - czas pracy } j \text {-tego gospodarstwa domowego } \\
\text { - popyt na pracę w zawodzie } j \\
\text { - czas pracy gospodarstw niericardiańskich } \\
\text { - czas pracy gospodarstw ricardiańskich } \\
\text { - podaż pracy } \\
\text { - agregatowy indeks zatrudnienia } \\
\text { - zagregowany indeks zatrudnienia zaangażowany w produkcje } i \text {-tego dobra } \\
\text { pośredniego }\end{array}$ \\
\hline $\begin{array}{l}\mathrm{M} \\
\mathrm{m}\end{array}$ & $\begin{array}{l}m_{t} \\
m_{t}^{j} \\
\mathrm{mc}_{t} \\
M C_{t} \\
M T R_{j}\end{array}$ & $\begin{array}{l}\text { - podaż pieniądza } \\
\text { - zasób pieniądza posiadany przez } j \text {-te gospodarstwo domowe } \\
\text { - realny koszt krańcowy } \\
\text { - koszt krańcowy } \\
\text { - krańcowa stopa podatkowa dla j-tego przedziału podatkowego }\end{array}$ \\
\hline $\mathrm{N}, \mathrm{n}$ & $N W_{t}^{j}$ & - stawka płac netto otrzymywana przez $j$-te gospodarstwo domowe \\
\hline $\mathrm{P}, \mathrm{p}$ & $\begin{array}{l}p_{t} \\
p_{t}(i) \\
p_{i, t} \\
P_{t} \\
P_{t}^{B} \\
P_{I N D, t} \\
P_{O P T, t} \\
P I T_{t} \\
\text { pit }_{t}\end{array}$ & $\begin{array}{l}\text { - poziom cen } \\
\text { - cena } i \text {-tego dobra pośredniego } \\
\text { - cena dobra } i \text { w koszyku konsumowanych dóbr } \\
\text { - cena dobra finalnego wytwarzanego na podstawie dóbr pośrednich } \\
\text { - cena jednookresowych obligacji } \\
\text { - cena ustalana przez firmy dokonujące indeksacji } \\
\text { - cena ustalana przez firmy dokonujące optymalizacji } \\
\text { - wpływy z podatku dochodowego od osób fizycznych } \\
\text { - wpływy z PIT przypadające na jednego podatnika }\end{array}$ \\
\hline
\end{tabular}




\begin{tabular}{|c|c|c|}
\hline $\mathrm{Q}, \mathrm{q}$ & $\begin{array}{l}Q_{t} \\
Q_{T, t} \\
\end{array}$ & $\begin{array}{l}\text { - wartość kapitału } \\
\text { - współczynnik Q-Tobina }\end{array}$ \\
\hline $\mathrm{R}, \mathrm{r}$ & $\begin{array}{l}r_{t} \\
r_{t}^{*} \\
r_{t}^{k} \\
r_{t}^{n} \\
r_{\pi^{\prime}} r_{Y} r_{\Delta} \\
R_{t} \\
\hat{R}_{t} \\
R_{i, t} \\
R_{j, t}^{C} \\
R_{t}^{G} \\
R_{i, t}^{S}\end{array}$ & $\begin{array}{l}\text { - realna stopa procentowa } \\
\text { - naturalna stopa procentowa } \\
\text { - stopa zwrotu z wynajmu kapitału rzeczowego } \\
\text { - nominalna stopa procentowa } \\
{ }_{\pi} r_{\Delta Y} \quad \text { parametry w regule Taylora } \\
\text { - nominalna całkowita stopa zwrotu z obligacji } \\
\text { - czynnik dyskontowy } \\
\text { - dochody publiczne kategorii } i \\
\text { - cykliczne dochody publiczne kategorii } i \\
\text { - dochody publiczne } \\
\text { - strukturalne dochody publiczne kategorii } i\end{array}$ \\
\hline $\mathrm{S}, \mathrm{s}$ & $\begin{array}{l}S_{t} \\
S \\
S S C_{t}\end{array}$ & $\begin{array}{l}\text { - inwestycje rozpoczęte w okresie } t \\
\text { - funkcja kosztów związanych ze zmianami poziomu inwestycji } \\
\text { - dochody funduszy celowych ze składek }\end{array}$ \\
\hline $\mathrm{T}, \mathrm{t}$ & $\begin{array}{l}T_{t} \\
T_{t}^{N R} \\
T_{t}^{R} \\
T B_{i} \\
\operatorname{Tr}_{t} \\
\operatorname{Tr}_{t}^{j}\end{array}$ & $\begin{array}{l}\text { - zryczałtowane podatki } \\
\text { - zryczałtowane podatki płacone przez gospodarstwa niericardiańskie } \\
\text { - zryczałtowane podatki płacone przez gospodarstwa ricardiańskie } \\
\text { - baza podatkowa } i \text {-tego podatku } \\
\text { - transfery } \\
\text { - transfery otrzymywane przez } j \text {-te gospodarstwo domowe }\end{array}$ \\
\hline $\mathrm{U}, \mathrm{u}$ & $\begin{array}{l}u \\
u_{c}^{j} \\
u_{K, t}^{j} \\
U\end{array}$ & $\begin{array}{l}\text { - użyteczność chwilowa gospodarstwa domowego / stopa bezrobocia } \\
\text { - krańcowa użyteczność konsumpcji j-tego gospodarstwa domowego } \\
\text { - stopień wykorzystania kapitału rzeczowego } \\
\text { - suma zdyskontowanych użyteczności gospodarstwa domowego }\end{array}$ \\
\hline $\mathrm{V}, \mathrm{v}$ & $\begin{array}{l}v_{t} \\
v_{i, t} \\
v_{i, t}^{g} \\
V\end{array}$ & $\begin{array}{l}\text { - wpływ przyzwyczajeń konsumpcyjnych na poziom konsumpcji } \\
\text { - wpływ przyzwyczajeń na konsumpcję prywatną dobra } i \\
\text { - wpływ przyzwyczajeń na konsumpcję publiczną dobra } i \\
\text { - funkcja określająca wpływ czasu wolnego na użyteczność w funkcji } \\
\text { użyteczności }\end{array}$ \\
\hline $\begin{array}{l}\mathrm{W}, \\
\mathrm{w}\end{array}$ & $\begin{array}{l}w_{t} \\
w_{j, t} \\
W_{t} \\
W_{t}^{j} \\
W_{I N D, t} \\
W_{O P T, t}\end{array}$ & $\begin{array}{l}\text { - realna stawka płac } \\
\text { - stawka płac w zawodzie } j \\
\text { - nominalna stawka płac } \\
\text { - nominalna stawka płac uzyskiwana przez } j \text {-te gospodarstwo domowe } \\
\text { - stawka płac ustalana na podstawie indeksacji } \\
\text { - stawka płac ustalana przez gospodarstwa domowe podejmujące decyzje } \\
\text { optymalizacyjne }\end{array}$ \\
\hline
\end{tabular}




\begin{tabular}{|l|ll|}
\hline $\mathrm{Y}, \mathrm{y}$ & $y_{t}$ & - produkcja \\
& $\tilde{y}_{t}$ & - luka produktowa \\
& $y_{t}(i)$ & - produkcja $i$-tego dobra pośredniego \\
& $y_{t}^{d}$ & - popyt na rynku dóbr i usług \\
& $y_{t}^{s}$ & - podaż na rynku dóbr i usług \\
& $Y_{t}$ & - produkcja dobra finalnego wytwarzanego na podstawie dóbr pośrednich \\
& $Y_{t}^{j}$ & - dochody netto $j$-tego gospodarstwa domowego \\
& $Y_{t}^{P}$ & - produkcja potencjalna \\
\hline $\mathrm{Z}, \mathrm{z}$ & $z_{t}$ & - szok technologiczny \\
\hline
\end{tabular}




\section{Od redakcji}

Dr Piotr Krajewski jest adiunktem w Instytucie Ekonomii Uniwersytetu Łódzkiego. Specjalizuje się w tematyce polityki fiskalnej. Jego zainteresowania naukowe w szczególności koncentrują się wokół zagadnień związanych z wpływem polityki fiskalnej na gospodarkę oraz oddziaływaniem wahań koniunktury na stan finansów publicznych. W 2005 roku obronił pracę doktorską pt. Strukturalny $i$ cykliczny komponent deficytu budzetowego $w$ Polsce, napisaną pod kierunkiem prof. Marka Belki. Praca została opublikowana w 2006 roku w ramach serii wydawniczej Uniwersytetu Łódzkiego Prace Doktorskie z Zakresu Ekonomii i Zarządzania. Wyróżniona została III nagrodą w kategorii prac doktorskich w ramach XV edycji Konkursu im. prof. Witolda Kuli oraz Indywidualną nagrodą III stopnia Rektora Uniwersytetu Łódzkiego. Dr Piotr Krajewski jest autorem licznych opracowań naukowych z zakresu polityki fiskalnej, publikowanych m.in. w „Ekonomiście”, „Gospodarce Narodowej”, „Studiach Ekonomicznych”, „Wiadomościach Statystycznych” oraz czasopismach zagranicznych. Jest współautorem kilkunastu monografii, w tym książki Deficyt budżetowy. Przyczyny i metody ograniczenia wydanej przez PWE w 2006 roku, napisanej wspólnie z prof. Cezarym Józefiakiem oraz dr. hab. Michałem Mackiewiczem. Dr Piotr Krajewski jest również współautorem podręcznika Podstawy ekonomii matematycznej, który otrzymał I nagrodę w konkursie Polskiego Towarzystwa Ekonomicznego na najlepszy podręcznik akademicki z ekonomii w latach 2007-2009. Uczestniczył w kilkunastu dużych projektach badawczych, dotyczących głównie polityki fiskalnej oraz rynku pracy. Kierował projektem badawczym „Ocena wpływu cykliczności polityki fiskalnej na synchronizację cyklu koniunkturalnego w Polsce i strefie euro" realizowanym w ramach II Konkursu Komitetu Badań Ekonomicznych NBP. Dr Piotr Krajewski brał udział w kilku projektach międzynarodowych, m.in. był głównym wykonawcą w ramach projektu badawczego "The roots of excessive deficits in Poland - the political economy perspective" finansowanego przez Bank Światowy. W latach 2000-2001 pełnił funkcję doradcy ministra finansów Jarosława Bauca, a w 2003 roku - doradcy ministra finansów Andrzeja Raczko. 